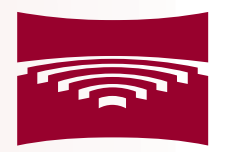

Rígas STRADIN̦A UNIVERSITĀTE

\title{
Vladislavs Anan,jevs
}

\section{Divfāžu kalcija fosfāta biokeramikas ietekme uz osteoporotisku kaulu biomehāniskiem rādītājiem un minerālblīvumu (eksperimentāls pētījums)}

Promocijas darbs zinātniskā doktora grāda "zinātnes doktors (Ph.D.)" iegūšanai

Nozare - mediciniskā inženierija Apakšnozare - biomehānika

$$
\text { Rīga, } 2021
$$




\section{RİGAS STRADINA}

Vladislavs Ananjjevs

ORCID 0000-0002-0498-1403

\section{Divfāžu kalcija fosfāta biokeramikas ietekme uz osteoporotisku kaulu biomehāniskiem rādītājiem un minerālblīvumu (eksperimentāls pētījums)}

Promocijas darbs zinātniskā doktora grāda "zinātnes doktors (Ph.D.)" iegūšanai

Nozare - medicīniskā inženierija Apakšnozare - biomehānika

Promocijas darba vadītāji:

Dr. habil. med. profesors Jānis Vētra

Rīgas Stradiṇa universitāte, Latvija Dr. habil. sc. ing. profesors Vladimirs Kasjanovs

Rīgas Stradiṇa universitāte, Latvija

Zinātniskais konsultants:

Dr. med., Dr. habil. med. profesors Andrejs Skagiers

Rìgas Stradiṇa universitāte, Latvija

Rīga, 2021 


\section{Anotācija}

Kaula reǵenerācija ir kaulaudu veidošanās fiziologiiskais process, kas notiek normāla lūzuma sadzīšanas laikā un ir iesaistīts nepārtrauktā kaula aprites procesā dzīves laikā. Tomēr ir dažādi klīniski apstākḷi, kad nepieciešama plaša kaula reǵenerācija, piemēram, osteoporotisko kaulu lūzumu gadījumos. Kalcija fosfātu saturošs biomateriāls - hidroksiapatīts, kas var būt gan tîrā veidā, gan pārklāts ar medikamentiem, ir viens no pazīstamākajiem un klīniski izpētīitiem kaulaudu atjaunošanas līdzekḷiem. Divfāžu kalcija fosfāta biokeramika kā kaulu aizstājējmateriāls tiek izmantots, lai uzlabotu osteoporotisko kaulu īpašǐbas un veicinātu kaulaudu dzīšanu. Stronciju saturošie kalcija fosfăta kaulaudu cementi ir perspektīvi materiāli ar osteoporozi saistîtu defektīvu kaulu reǵenerācijai, jo tie stimulē kaulu veidošanos un vienlaikus ierobežo osteoklastu darbību.

Pētījuma mērḳis bija noteikt kaulaudu minerālblīvuma, biomehānisko un morfolog̣isko īpašību izmainas pēc lokālas augšstilba kaula trochanter major apvidus pastiprināšanas ar divfāžu kalcija fosfāta biokeramiskajiem materiāliem trušiem ar eksperimentālu osteoporozi.

Pētijjumā tika izmantoti 34 astoṇus mēn. veci sieviešu dzimtes eksperimenta dz̄ivnieki - truši, 24 no kurām tika izraisīta-eksperimentāla osteoporoze pēc ovariektomijas un sekojošas metilprednizolona injekcijas. Kontroles grupā bija 10 veseli truši. Pētījumam tika izmantoti nekomerciālie Rīgas Tehniskās universitātes Rūdolfa Cimdina Rīgas biomateriālu inovāciju un attīstības centrā ražoti biomateriāli - divfăžu kalcija fosfăta biokeramika - kalcija hidroksiapatîts (HAP) un trikalcija fosfāts (TCP) attiecībā 70/30. Osteoporozes skartie truši tika sadalīti grupās un labajā (operētā) augšstilbā izveidotais defekts tika aizpildīts ar HAP/TCP granulām ar vai bez $5 \%$ stroncija (Sr) vai atstāts tukšs kā placebo ķirurǵijas grupa.

Osteoporozes pierādīšanai ar morfologiskā pētījuma metodi tika n̦emti 10 apakšžokḷa kaula premolāra rajona paraugi no veseliem (kontroles) trušiem un 23 apakšžokḷa kaula premolāra rajona paraugi no trušiem ar eksperimentālo osteoporozi. Lai noteiktu biomateriālu lokālo ietekmi, tika izmantoti 23 labajā (operēta) augšstilba kaula paraugi, kā arī 23 kreisajā (neoperēta) augšstilba un 23 apakšžokḷa kaula leṇka rajona paraugi no trušiem ar eksperimentālo osteoporozi, lai noteiktu sistēmisku biomateriāla iedarbību ar biomehāniskā un rentgenolog̣iskā pētijuma metodēm.

Apakšžokḷa kaula šḳersgriezumā trabekulārā kaula laukums kontroles grupā bija $0,20 \mathrm{~mm}^{2}\left(0,176-0,233 \mathrm{~mm}^{2}\right)$, kas ir statistiski ticami lielāks nekā osteoporotisku dzīvnieku grupām (HAP/TCP grupā $\left(0,127 \mathrm{~mm} 2 ; 0,118-0,149 \mathrm{~mm}^{2}\right)$, HAP/TCP/5\% Sr grupā $\left(0,136 \mathrm{~mm}^{2} ; 0,108-0,166 \mathrm{~mm}^{2}\right)$ un placebo ķirurǵijas grupā $\left.\left(0,135 \mathrm{~mm}^{2} ; 0,126-0,164 \mathrm{~mm}^{2}\right)\right)$.

Pētījuma ietvaros kaulaudu biomehānisku parametru noteikšanai tika veikts trīs punktu lieces izpētes tests. Lieces laikā katram paraugam tika noteikts graujošais spriegums un 
graujošā deformācija. Paraugu cietība tika izteikta kā pieskares lieces modulis. Operēta, neoperēta augšstilba un apakšžokḷa kaula paraugu graujoša deformācija pēc HAP/TCP biomateriāla implantācijas ar vai bez 5 \% Sr bija statistiski ticami mazāka, salīdzinot ar placebo ķirurǵijas grupu paraugu graujošo deformāciju. Neoperēta augšstilba kaula paraugu graujošais spriegums pēc HAP/TCP biomateriāla implantācijas ar vai bez $5 \%$ Sr bija statistiski ticami lielāks, salīdzinot ar placebo ķirurğijas grupas paraugu graujošo spriegumu. Statistiski ticamas atšķirības starp operēta augšstilba un apakšžokḷa kaula placebo ķirurǵijas grupu kaula paraugiem un kaula paraugiem pēc HAP/TCP biomateriāla implantācijas ar vai bez $5 \% \mathrm{Sr}$ netika atrastas. Operēta, neoperēta augšstilba un apakšžokḷa kaula paraugu elastības modulis pēc HAP/TCP biomateriāla implantācijas ar vai bez $5 \% \mathrm{Sr}$ bija statistiski ticami lielāks, salīdzinot ar placebo k̦irurğijas grupu paraugu elastības moduli.

Operēta, neoperēta augšstilba un apakšžokḷa kaula paraugu minerālblīvums pēc HAP/TCP biomateriāla implantācijas ar vai bez $5 \%$ Sr bija statistiski ticami lielāks, salīdzinot ar placebo ķirurğijas grupu paraugu minerālblīivumu, kas liecina par sistēmisku biomateriālu iedarbību uz eksperimentālo dzīvnieku kaulaudiem. Tas rada biomateriālu izmantošanas perspektīvu osteoporozes ārstēšanai un profilaksei.

Statistiski ticamas atšķirības starp operēto un neoperēto augšstilba kaula paraugu graujošo deformāciju, graujošo spriegumu, lieces moduli un minerālblīvumu pēc HAP/TCP un HAP/TCP ar $5 \%$ Sr biomateriālu implantācijas netika atrastas, kas liecina par vienādu biomateriālu iedarbību uz eksperimentālo dzīvnieku kaulaudiem, kas atrodas attālināti no implantācijas vietas.

Analizējot osteoporotisku kaulaudu paraugu biomehāniskus rādītājus pēc HAP/TCP biomateriāla implantācijas ar vai bez $5 \%$ Sr, tikai operēta augšstilba kaula paraugiem novērotas statistiski ticamas izmaiņas visos biomehāniskos parametros, liecinot par kaula stiprības veicināšanu stroncija klātbūtnē. Statistiski ticamas neoperēta augšstilba kaula paraugu biomehāniskos rādītāju, kā arī apakšžokḷa kaula paraugu graujošās deformācijas un elastîbas moduḷa atšķirības starp HAP/TCP un HAP/TCP 5 \% Sr grupām netika atrastas. Kā arī netika atrastas statistiski ticamas operēta, neoperēta augšstilba un apakšžokḷa kaula paraugu minerālbīvuma atšķirības starp $\mathrm{HAP} / \mathrm{TCP}$ un HAP/TCP $5 \% \mathrm{Sr}$ grupām. Iespējams, nepieciešami turpmāki pētījumi ar lielāku stroncija daudzumu biomateriālā, lai sasniegtu klīnisku efektu. 


\begin{abstract}
Bone regeneration is a physiological process of bone formation that occurs during normal fracture healing and is involved in a continuous process of bone remodeling during life. However, there are a variety of clinical conditions that require extensive bone regeneration, such as osteoporotic bone fractures. Calcium phosphate containing biomaterials, such as hydroxyapatite, which can be in pure form or coated with drugs, is one of the best known and clinically researched bone regeneration products. Biphasic calcium phosphate bioceramics is used as a bone substitute to improve osteoporotic bone properties and promote bone healing. Strontium-containing calcium phosphate bone cements are promising materials for the recovery of bone defects associated with osteoporosis, as they stimulate bone formation and at the same time limit the activity of osteoclasts.
\end{abstract}

The aim of the study was to determine the changes in bone mineral density, biomechanical and morphological properties after local amplification of the trochanter major area of the femur with biphasic calcium phosphate bioceramic materials in rabbits with experimental osteoporosis.

The study used 34 eight month old female experimental animals - rabbits, 24 of which developed experimental osteoporosis after ovariectomy and subsequent injection of methylprednisolone. There were 10 healthy rabbits in the control group. Non-commercial biomaterials produced at the Riga Technical University Rudolfs Cimdins Riga Biomaterials Innovation and Development Center were used for the study - biphasic calcium phosphate bioceramics - calcium hydroxyapatite (HAP) and tricalcium phosphate (TCP) in the ratio of 70/30. Rabbits affected by osteoporosis were divided into groups and the defect in the right (operated) femur was filled with HAP/TCP granules with or without 5\% Strontium (Sr) or left blank as a placebo surgery group.

To demonstrate osteoporosis by morphological examination, 10 samples of the mandibular premolar region were taken from healthy (control) rabbits and 23 samples of the mandibular premolar region from rabbits with experimental osteoporosis. To determine the local effects of biomaterials, 23 samples of the right (operated) femur, 23 samples of the left (non-operated) femur and 23 samples of mandibular angle from rabbits with experimental osteoporosis were used to determine the systemic exposure of biomaterials by biomechanical and radiological methods.

In the cross-section of the mandibular bone, the trabecular bone area in the control group was $0.20 \mathrm{~mm}^{2}\left(0.176-0.233 \mathrm{~mm}^{2}\right)$, which is statistically significantly higher than in the osteoporotic groups (HAP/TCP group $\left(0.127 \mathrm{~mm}^{2} ; 0.118-0.149 \mathrm{~mm}^{2}\right), \mathrm{HAP} / \mathrm{TCP} / 5 \%$ Sr group $\left(0.136 \mathrm{~mm}^{2} ; 0.108-0.166 \mathrm{~mm}^{2}\right)$ and placebo surgery group $\left.\left(0.135 \mathrm{~mm}^{2} ; 0.126-0.164 \mathrm{~mm}^{2}\right)\right)$. 
Within the framework of the study, a three-point bending test was performed to determine biomechanical parameters of bone tissue. During bending, the destructive stress and destructive deformation were determined for each specimen. The hardness of the specimens was expressed as the modulus of elasticity. The destructive deformity of the operated, nonoperated femur and mandibular bone samples after implantation of HAP/TCP biomaterial with or without $5 \%$ Sr was statistically significantly lower compared to the destructive deformation of the samples in the placebo surgical groups. The destructive stress of non-operated femoral specimens after implantation of HAP/TCP biomaterial with or without $5 \% \mathrm{Sr}$ was statistically significantly higher compared to the destructive stress of samples in the placebo surgical group. No statistically significant differences were found between bone samples from the operated femur and mandible bone placebo surgery groups and bone samples after implantation of HAP/TCP biomaterial with or without $5 \% \mathrm{Sr}$. The modulus of elasticity of operated, nonoperated femur and mandibular bone samples after implantation of HAP/TCP biomaterial with or without $5 \% \mathrm{Sr}$ was statistically significantly higher compared to the modulus of elasticity of placebo surgery groups samples.

The mineral density of operated, non-operated femur and mandibular bone samples after implantation of HAP/TCP biomaterial with or without $5 \% \mathrm{Sr}$ was statistically significantly higher compared to the mineral density of samples from placebo surgery groups, which indicates the effect of systemic biomaterials on bone of experimental animals. This opens up the prospect of the use of biomaterials for the treatment and prevention of osteoporosis.

No statistically significant differences were found between the destructive deformation, destructive stress, flexural modulus and mineral density of operated and non-operated femur specimens after HAP/TCP and HAP/TCP with $5 \%$ Sr biomaterials, indicating the same effect of biomaterials on the bone tissue of experimental animals remotely from the implantation site.

Analyzing the biomechanical parameters of osteoporotic bone samples after implantation of HAP/TCP biomaterial with or without $5 \% \mathrm{Sr}$, only statistically significant changes in all biomechanical parameters were observed for operated femur bone samples, indicating the promotion of bone strength in the presence of Strontium. No statistically significant differences were found in the biomechanical parameters of non-operated femur samples, as well as in the destructive deformation and modulus of elasticity of the mandibular bone samples between the HAP/TCP and HAP/TCP $5 \% \mathrm{Sr}$ groups. Also, no statistically significant differences were found in the mineral density of operated, non-operated femur and mandibular bone samples between the HAP/TCP and HAP/TCP $5 \% \mathrm{Sr}$ groups. Further studies with higher levels of Strontium in the biomaterial may be required to achieve a clinical effect. 


\section{Saturs}

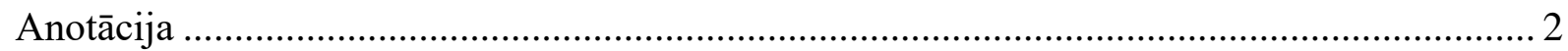

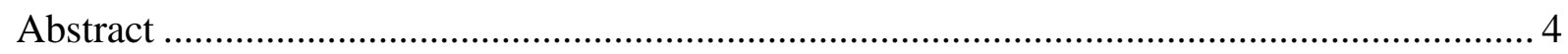

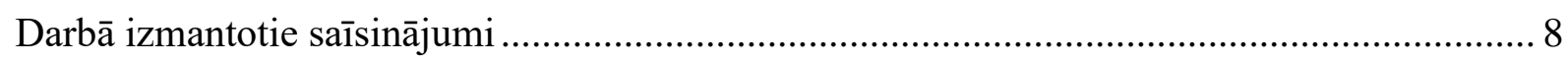

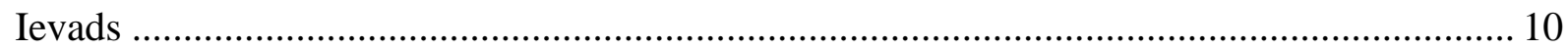

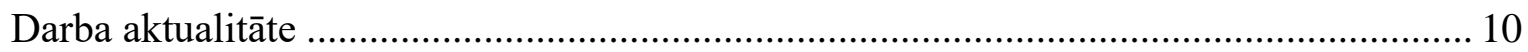

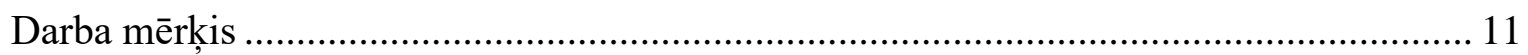

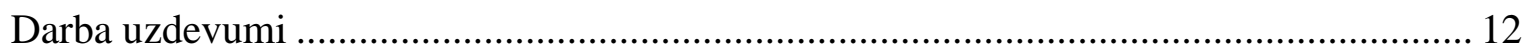

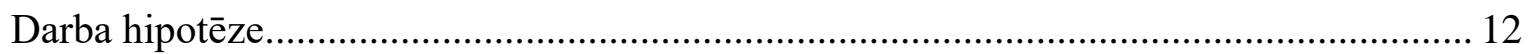

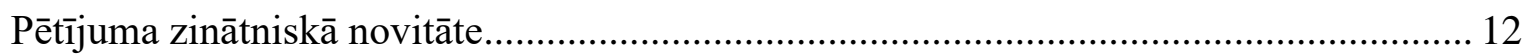

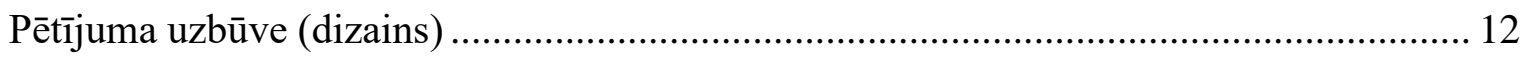

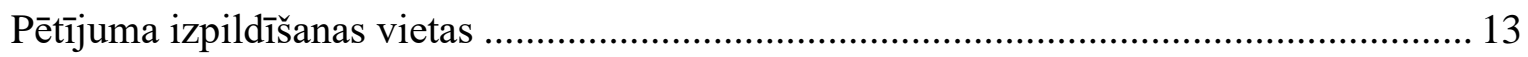

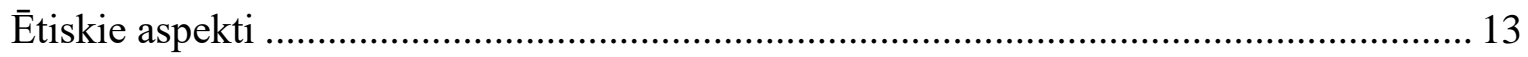

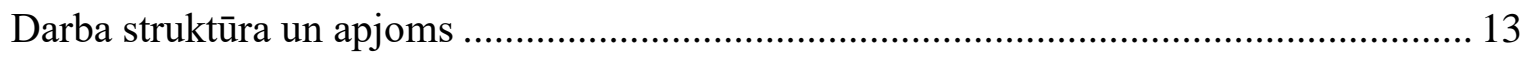

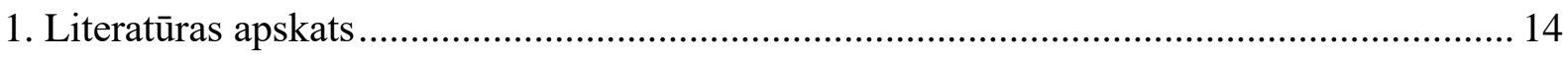

1.1. Kaulu uzbūve - anatomija un fiziologija .............................................................. 14

1.2. Kaula aprites cikla endokrīna regulācija ................................................................. 23

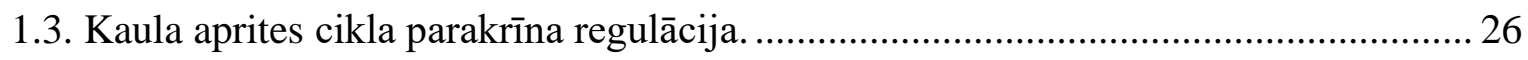

1.4. Kaula aprites cikla novirzes osteoporozes laikā...................................................... 27

1.5. Osteoporotiskā trabekulārā kaula izmain,as............................................................ 28

1.6. Osteoporotiskā kortikālā kaula izmaiņas.................................................................. 32

1.7. Osteoporozes medikamentozās terapijas ietekme uz kaulaudu kvalitāti .................... 34

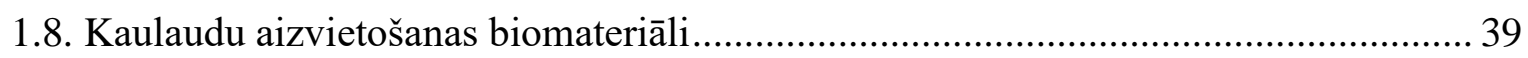

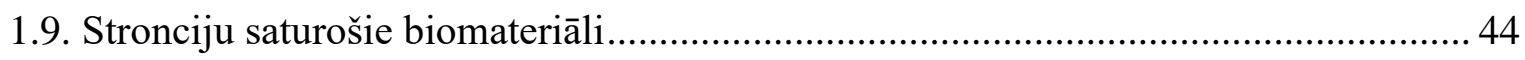

1.10. Kalcija fosfātu saturošo materiālu bioaktivitāte................................................... 45

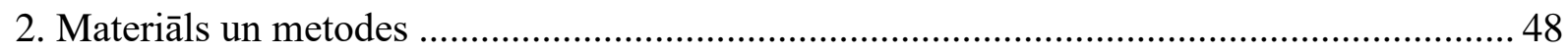

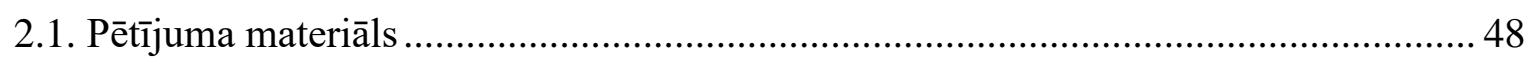

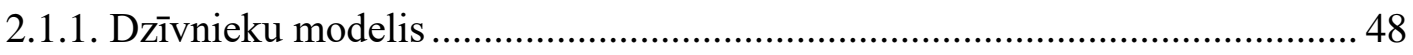

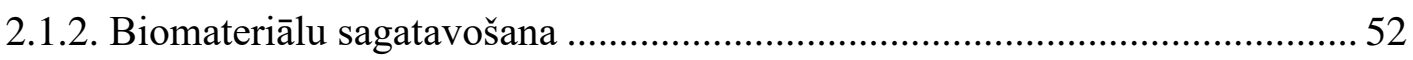

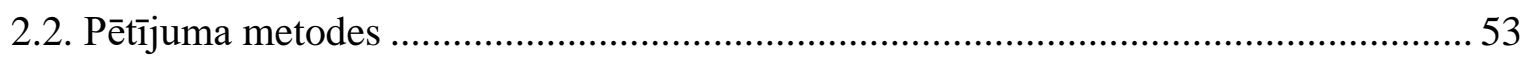

2.2.1. Biomehāniskā pētījuma metode ................................................................. 53

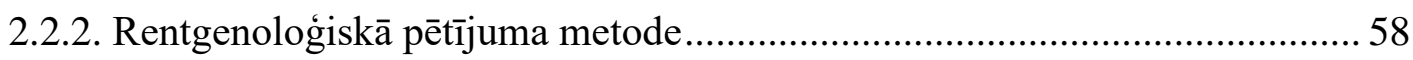

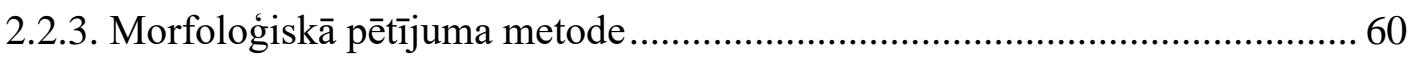

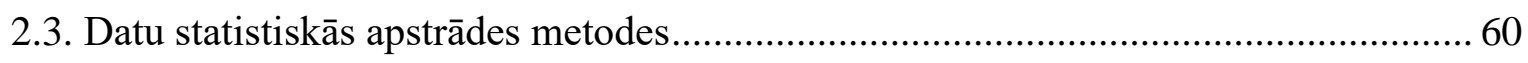

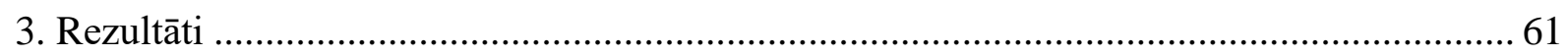

3.1. Biomehāniskā pētījuma un datu statistiskās apstrādes rezultāti augšstilba kaula paraugos 
3.1.1. Graujošās deformācijas noteikšanas un datu statistiskās apstrādes rezultāti. 61

3.1.2. Graujošā sprieguma noteikšanas un datu statistiskās apstrādes rezultāti ...... 62

3.1.3. Lieces moduḷa noteikšanas un datu statistiskās apstrādes rezultāti .....

3.2. Biomehāniskā pētījuma un datu statistiskās apstrādes rezultāti apakšžokḷa kaula

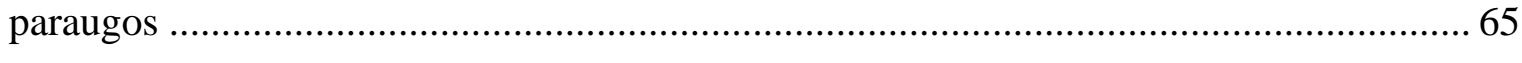

3.2.1. Graujošās deformācijas noteikšanas un datu statistiskās apstrādes rezultāti. 65

3.2.2. Graujošā sprieguma noteikšanas un datu statistiskās apstrādes rezultāti ...... 65

3.2.3. Lieces moduḷa noteikšanas un datu statistiskās apstrādes rezultāti ............... 66

3.3. Rentgenologiskā pētījuma un datu statistiskās apstrādes rezultāti augšstilba kaula paraugos

3.4. Rentgenologiskā pētîjuma un datu statistiskās apstrādes rezultāti apakšžokḷa kaula paraugos

3.5. Operēta un neoperēta augšstilba biomehānisko parametru un minerālblīvuma salīdzinājums pēc dažāda biomateriāla implantācijas

3.6. Morfologiskā pētījuma un datu statistiskās apstrādes rezultāti apakšžokḷa kaula

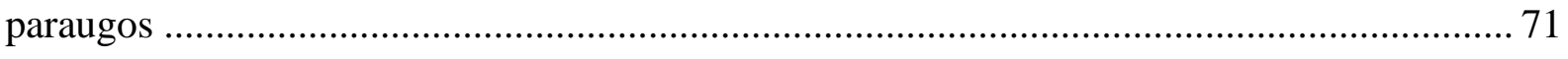

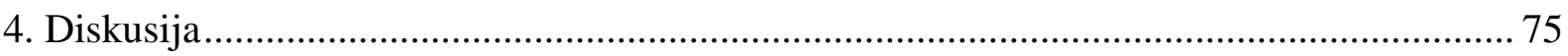

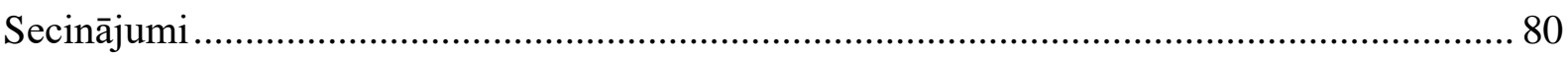

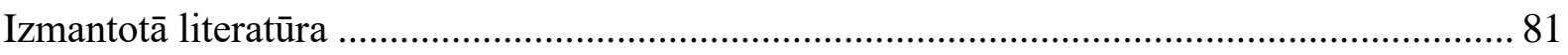

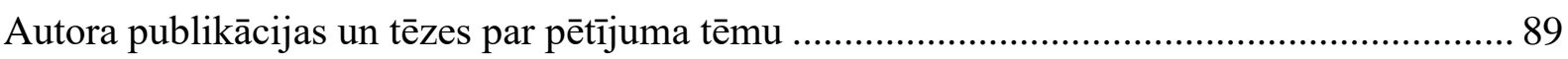

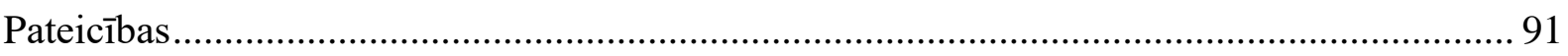

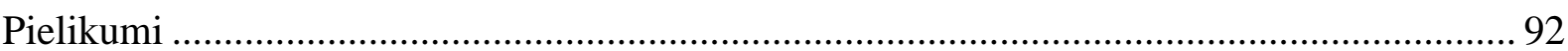




\section{Darbā izmantotie saīsinājumi}

ATF Adenozīna trifosfotāze (Adenosine triphosfate)

BMP Kaulu morfoǵenētiskais proteīns (Bone morphogenic protein)

CSF Kolonijas stimulējošais faktors (Colony-stimulating factor)

DKK Dickkopf saistīts proteīns (Dikkopf protein)

FDA Pārtikas un zālu administrācija (Food and Drug Administration)

GPa Gigapaskals (Gigapascal)

HAP Hidroksiapatîts (Hydroyapatite)

HU Haunsfìlda vienības (Hounsfield units)

IGF Insulīnam līdzīgais augšanas faktors (Insulin-like growth factor)

IL Interleikīns (Interleukin)

KMB Kaula minerālais blīvums (Bone mineral density)

KSDT Konusa staru datortomogrāfija (Cone beam computed tomography)

LLU Latvijas Lauksaimniecības universitāte (Latvia University of Life Sciences and Technologies)

MCP Monocītu hemotaktiskais proteīns (Monocyte chemoattractant protein)

MPa Megapaskāls (Megapascal)

OPG Osteoprotegerīns (Osteoprotegerin)

$\mathrm{p} \quad$ Būtiskuma (nozīmības) līmenis (The level of marginal significance)

Pa Paskāls (Pascal)

PMMA Polimetilmetakrilāts (Polymethyl methacrylate)

PTH Paratireoīdais hormons (Parathyroid hormone)

PTHrP Ar paratireoīdo hormonu saistītais peptīds (Parathyroid hormone-related protein)

RANK Kodola faktora kapa $\beta$ receptora aktivators (Receptor activator of nuclear factor kapa $\beta$ )

RANKL Kodola faktora kapa $\beta$ liganda receptora aktivators (Receptor activator of nuclear factor kapa $\beta$ ligand)

RSU Rīgas Stradina universitāte (R̄̄ga Stradiṇš University)

RUNX Runt saistītais transkripcijas faktors (Runt-related transcription factor)

SD Standarta deviācija (Standard deviation)

SOST Sklerostīna kodējošs gēns (Sclerostin coding gene)

sRANKL Šḳīstošais kodola faktora kapa $\beta$ receptora liganda aktivators (Soluble receptor activator of nuclear factor kapa $\beta$ ligand) 
TCP Trikalcija fosfāts (Tricalcium phosphate)

TGF Transformējošais augšanas faktors (Transforming growth factor)

VPP Valsts pētniecības programma (National research program) 


\section{Ievads}

\section{Darba aktualitāte}

Osteoporoze ir sistēmiska skeletālā slimība, kurai raksturīga samazināta kaulu masa un kaulaudu mikroarhitektūras izmaiņas, kā rezultātā palielinās kaulu trauslums (Blanchard et al., 2019). Palielinoties iedzīvotāju vecumam un dzīvildzei, osteoporoze kḷūst arvien plašāk izplatîta. Ar sabiedrības novecošanos osteoporoze arvien vairāk kḷūst par globālu problēmu. Pašlaik osteoporoze skar vairāk nekā 200 miljonus cilvēku visā pasaulē. Eiropas valstīs aptuveni $30 \%$ sieviešu, kas ir pēcmenopauzes periodā, tiek diagnosticēta osteoporoze (Sözen et al., 2017).

Osteoporozes profilakse ir kritienu nepiel̦aušana, redzes un dzirdes traucējumu novēršana, fiziskās aktivitātes, smēḳēšanas un alkohola lietošanas pārtraukšana, kā arī atbilstoša D vitamīna, olbaltumvielu un kalcija uzṇemšana (Föger-Samwald et al., 2020). Osteoporozes medikamentozā ārstēšanā parasti tiek izmantoti perorālie bifosfonāti (alendronāts, risedronāts un ibandronāts). Sievietēm, kurām ir perorālu bifosfonātu grupas medikamentu nepanesība (vai tie ir kontrindicēti), intravenoza bifosfonātu vai denosumaba lietošana ir vislabākā alternatīva (Kanis et al., 2019). Aptuveni viena no trīs sievietēm un viens no pieciem vīriešiem pēc 50 gadu vecuma piedzīvo osteoporotiskus lūzumus. Osteoporozes izraisīti lūzumi palielina saslimstību un pāragru mirstību, it sevišķi gados vecākiem cilvēkiem (Sözen et al., 2017). Osteoporotisko lūzumu ārstēšana viņiem ir problemātiska, jo ir mazākas lūzumu dzī̌šanas spējas, kas korelē ar daudz augstāku implanta fiksācijas neveiksmju līmeni salīizinājumā ar jaunākiem pacientiem. Bieži tiek veiktas ķirurğiskas procedūras, lai salabotu bojāto kaulu, izmantojot skrūves vai fiksācijas plāksnes. Sakarā ar augsto porainību un zemo osteoporotisko kaulaudu izturību, lai uzlabotu iznākumu, implantus bieži papildina ar dažādiem kaula biomateriāliem (Offermanns et al., 2018).

Divdesmit pirmā gadsimta sākumā strauji sākās plaša biomateriālu izmantošana ortopēdijas praksē. Pēdējā desmitgadē vairākos veselības jomu segmentos tiek meklēti biologiski saderīgi materiāli defektīvu kaulu rekonstrukcijai (Ratner et al., 2013). Kaulaudu aizvietojošo biomateriālu izmantošanas iespēju pētniecība ir aktuāla arī Latvijā. Biomateriālam jābūt saderīgam ar implantācijas vietu, netoksiskam, nekancerogēnam, ķ1̄miski un biologíski stabilam, ar atbilstošu blīvumu, svaru, mehānisko izturību un elastību. Autogēnie kaula transplantāti, kas satur minerālo komponentu un daudz imūnkompetento šūnu osteoǵenēzei, ir labākais kaulaudu aizvietošanas materiāls, tomēr ir vajadzīgas divas ķirurgiiskas vietas un kaula avots ir ierobežots (Leite et al., 2008). 
Kaula reǵenerācija ir kaulaudu veidošanās fiziologiskais process, kas notiek normāla lūzuma sadzīšanas laikā un ir iesaistīts nepārtrauktā kaula aprites procesā dzīves laikā. Tomēr ir dažādi klīniski apstākḷi, kad nepieciešama plaša kaula reǵenerācija, piemēram, osteoporotisko kaulu lūzumu gadījumā (Dimitriou et al., 2011). Biokeramikas materiāliem ir milzīgs potenciāls dabisko kaulu audu atjaunošanai (Wang et al., 2017). Kalcija fosfătu saturošs biomateriāls - hidroksiapatîts (HAP), kas var būt gan tīrā veidā, gan pārklāts ar medikamentiem, ir viens no zināmākajiem un klīniski izpētītiem kaulaudu atjaunošanas līdzekḷiem. Kalcija fosfāts stimulē kaulu dzīšanu osteovadītspējas, biologiskās saderības un bionoārdīšanās īpašības dēḷ (Schlickewei et al., 2015). Divfāžu kalcija fosfāta biokeramika kā kaulu aizstājējmateriāls tiek izmantots, lai uzlabotu osteoporotisko kaulu īpašības un veicinātu kaulaudu dzīšanu. Kalcija hidroksiapatīts (HAP) ir ḷoti bioakumulatīvs un veido tiešu saikni ar kaulaudiem. Trikalcija fosfāts (TCP) darbojas kā katalizators jaunu kaulaudu veidošanās stimulěšanai (Ratner et al., 2013). Stronciju saturošie kalcija fosfăta kaulaudu cementi ir perspektīvi materiāli ar osteoporozi saistītu defektīvu kaulu reǵenerācijai, jo tie stimulē kaulu veidošanos un vienlaikus ierobežo osteoklastu darbību (Lode et al., 2017).

Rīgas Tehniskās universitātes Rūdolfa Cimdina Rịgas biomateriālu inovāciju un attīstības centrā tiek veikta kaulaudu aizvietojošu materiālu izpēte. Šim centram ir vairāk nekā 20 gadu pieredze sadarbībā ar Rīgas Stradina universitātes Mutes, sejas un žokḷu ḳirurǵijas katedru jaunu sintētisko biomateriālu eksperimentālajā un klīniskajā aprobācijā. Darbs norisinās pie hidroksiapatīta, divfāžu kalcija fosfăta cementa, polimetilmetakrilāta cementa, stikla-jonomēra cementa sintezēšanas un to īpašību pētniecības. No minētajiem materiāliem promocijas darba autora eksperimentālajā pētījumā ar dzīvniekiem tika izmantoti divfāžu kalcija fosfāta biokeramikas materiāli.

Jebkurš biomateriāls, kurš tiek implantēts dzīvā organismā, izraisa noteiktu lokālu reakciju. Reakcija ir atkarīga no materiāla fizikālajām un k̦īmiskajām īpašībām. Tika izstrādāta reaktogenitātes teorija, dalot audu reakciju uz implantāciju nespecifiskā un specifiskā reakcijā, kas kopā veido biosaderību (Slutskii et Vetra, 1996). Literatūrā ir maz datu par organisma vispārējo reakciju uz biomateriālu implantāciju. Joprojām nav noskaidrots, kādas ir kaulaudu īpašību izmaiṇas blakus implantācijas zonai un attālinātos rajonos pēc biomateriālu implantācijas.

\section{Darba mērḳis}

Pētījuma mērḳis ir noteikt kaulaudu minerālblīvuma, biomehānisko un morfologisko īpašību izmaiṇas pēc lokālas augšstilba kaula trochanter major apvidus pastiprināšanas ar divfāžu kalcija fosfāta biokeramiskajiem materiāliem trušiem ar eksperimentālu osteoporozi. 


\section{Darba uzdevumi}

1. Noteikt operēta, neoperēta augšstilba un apakšžokḷa kaula paraugu graujošo deformāciju dažādām eksperimentālo dzīvnieku grupām.

2. Noteikt operēta, neoperēta augšstilba un apakšžokḷa kaula paraugu graujošo spriegumu dažādām eksperimentālo dzīvnieku grupām.

3. Noteikt operēta, neoperēta augšstilba un apakšžokḷa kaula paraugu lieces moduli dažādām eksperimentālo dzīvnieku grupām.

4. Noteikt operēta, neoperēta augšstilba un apakšžokḷa kaula paraugu minerālblīvumu dažādām eksperimentālo dzīvnieku grupām.

5. Salīdzināt eksperimentālo dzīvnieku operēta un neoperēta augšstilba kaula paraugu biomehāniskus rādītājus un minerālblīvumu pēc dažāda veida biomateriālu implantācijas.

6. Statistiski salīdzināt iegūtos rezultātus starp dažādām eksperimentālo dz̄ivnieku grupām pēc biomateriālu implantācijas ar vai bez stroncija.

7. Noteikt apakšžokḷa kaula paraugu šḳērsgriezumā trabekulāra kaula laukumu pēc dažādu veidu biomateriālu implantācijas eksperimentālajiem dz̄ivniekiem un kontroles grupai.

\section{Darba hipotēze}

Lokāla pastiprināšana ar divfāžu kalcija fosfāta biokeramiskajiem materiāliem augšstilba trochanter major apvidū dzīvniekiem ar eksperimentālu osteoporozi uzlabo kaulaudu biomehānikās īpašības un palielina minerālblīvumu.

\section{Pētījuma novitāte}

Tika pierādīts, ka Rīgas Tehniskās universitātes Rūdolfa Cimdina Rịgas biomateriālu inovāciju un attīstības centra divfāžu kalcija fosfāta biokeramikas materiāli, kuri tiek izmantoti RSU Stomatologijas institūtā defektīvu kaulu aizvietošanai, pēc implantācijas osteoporotiskā kaulā ievērojami palielina tā minerāblīvumu un uzlabo biomehāniskās īpašības.

\section{Pētījuma uzbūve (dizains)}

Eksperimentāls salīdzinošs pētījums ar placebo ķirurğijas un kontroles grupu.

Pētījuma grupas: sieviešu dzimtes truši ar eksperimentāli izraisītu osteoporozi, kam augšstilba lielā grozītāja rajonā ievietotas divfāžu kalcija granulas ar un bez stroncija.

Placebo ķirurğijas grupa: dzīvnieki ar eksperimentāli izraisītu osteoporozi bez biomateriāla granulu ievietošanas kaulā.

Kontroles grupa: veseli dzīvnieki. 


\section{Pētījuma izpildīšanas vietas}

Rīgas Stradiṇa universitātes Biomehānikas laboratorija - kaulu paraugu biomehānisko īpašību noteikšana.

Rīgas Stradiṇa universitāte, Stomatologijijas institūts - kaulu paraugu minerālblīvuma noteikšana ar datortomogrāfijas palīdzību.

Rīgas Stradiṇa universitātes Patoloǵijas katedra - kaulu paraugu morfoloǵiskā analīze.

"Liepadent" zobārstniecības klīnikas zobu tehniskā laboratorija - kaulu paraugu sagatavošana biomehānisko īpašǐbu izpētei.

\section{Ētiskie aspekti}

Pētījums ir veikts, ievērojot ètikas normas, kas ir noteiktas eksperimentālo pētījumu veikšanai. Pētījumam ir izsniegta Latvijas Pārtikas un veterinārā dienesta atḷauja un Rīgas Stradiņa universitātes Ētikas komitejas atḷauja.

\section{Darba struktūra un apjoms}

Promocijas darbs uzrakstīts latviešu valodā. Tam ir klasiska struktūra un 10 daḷas: ievads, literatūras apskats, materiāls un metodes, rezultāti, diskusija, secinājumi, izmantotās literatūras saraksts, autora publikācijas un tēzes par pētījuma tēmu, pateicības un pielikumi. Promocijas darba apjoms: 106 lappuses, tajā skaitā 45 attēli un 1 tabula. Izmantotās literatūras sarakstā minēti 174 zinātnisku rakstu un 6 grāmatu avoti. 


\section{Literatūras apskats}

\subsection{Kaulu uzbūve - anatomija un fiziologija}

Pieauguša cilvēka skeletā apmēram ir 213 kauli, izṇemot ossa sesamoidea. Dzīves laikā katrs kauls tiek pastāvīgi remodelēts, lai palīdzētu tam pielāgoties mainīgajiem biomehāniskajiem spēkiem, kā arī lai aizstātu veco, bojāto kaulu vielu ar jaunu, mehāniski stiprāku, un palīdzētu saglabāt kaulu stiprību (Clarke, 2008).

Skelets pilda dažādas funkcijas: skeleta kauli nodrošina atbalstu ķermenim, l,auj kustēties, nodrošinot muskuḷu darbību, aizsargā dzīvībai svarīgus iekšējos orgānus, nodrošina minerālu homeostāzi un uztur skābju-bāzes līdzsvaru, kalpo kā augšanas faktoru un citokīnu rezervuārs, kā arī nodrošina vidi asinsradei (Taichman, 2005).

Visus kaulus ir pieņemts klasificēt pēc formas - izšķir garos, īsos, plakanos un neregulāras formas kaulus. Pie garo kaulu grupas pieder atslēgas kauls, augšdelma kauls, spieķkauls, elkoņa kauls, metakarpālie kauli, augšstilba kauls, lielais un mazais lielkauls, metatarsālie kauli, falangas. Pie īso kaulu grupas pieder karpālie un tarsālie kauli, ceḷa kauls un ossa sesamoidea. Pie plakano kaulu grupas pieder galvaskausa kauli, apakšžoklis, lāpstiņas, krūšu kauls un ribas. Neregulārās formas kaulu grupā ir mugurkaula skriemeḷi, krusta kauls, gūžas kauli un mēles kauls.

Šis kaulu iedalījums neaptver visu kaulu formu dažādību. Izšḳir vēl gaisu saturošos jeb pneimatiskos kaulus. Pie tiem pieder augšžoklis, pieres kauls, deniņu kauls, sietiņkauls un spārnkauls. Šo kaulu gaisa dobumiem ir atveres uz deguna dobumu. Kaulu forma atbilst to funkcijai: jo garāks ir kauls, jo garāks ir sviras plecs, kas l̦auj izdarīt ātras un plašas kustības. Ķermeṇa daḷās ar īsajiem kauliem kustības ir ierobežotas (Kalbergs, 1971).

Katram garajam kaulam izšķir vidusdaḷu (diafĩze) un divus noapoḷotos galus — epifîzes. Pārejas daḷu starp diafĩzi un epifĩzi sauc par metafĩzi. Diafīze sastāv no blīva kortikālā kaula ar noslēgto kanālveida dobumu, savukārt metafìze un epifize sastāv no trabekulāra kaula tīkla, apkārt kuram ir samērā plāns slānis ar kortikālo kaulu (Standring, 2015), (1.1. att). 


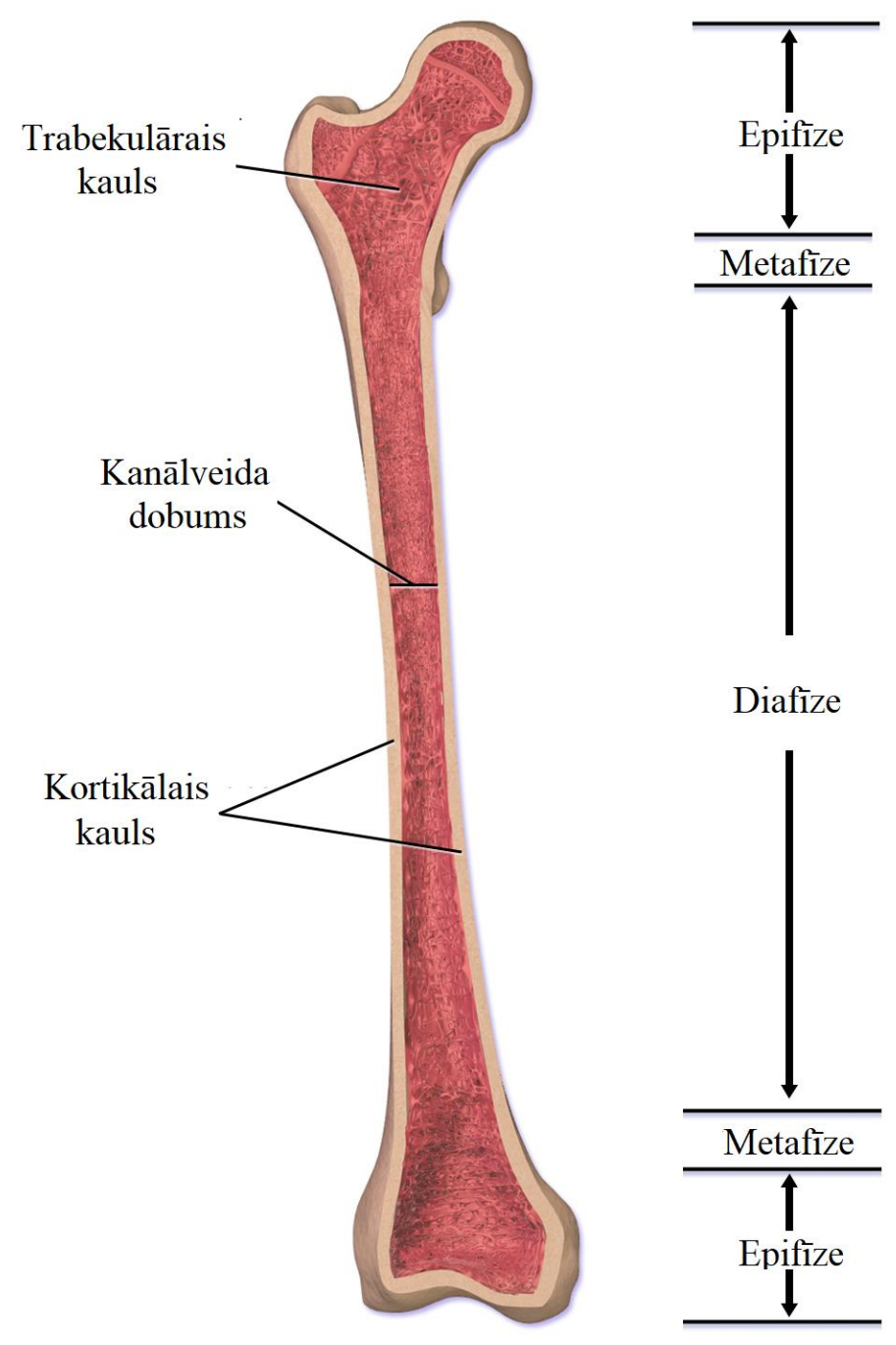

1.1. att. Shematisks garo kaulu struktūras zīmējums

(https://en.wikiversity.org/wiki/WikiJournal_of_Medicine/Medical_gallery_of_Blausen_Medical_2014)

Kaulaudi ir galvenā, funkcionāli svarīgākā kaula sastāvdaḷa, no kura ir atkarīga kaulu forma un cietība. Pēc uzbūves cilvēka skeletā ir divu veidu kauli - kortikālie un trabekulārie. Aptuveni 80\% no skeleta masas veido kortikālie un 20\% trabekulārie kauli. Dažādiem kauliem ir atšķirīgas kortikālā un trabekulārā kaulu attiecības. Mugurkaula skriemeliiem kortikālā un trabekulārā kaulu attiecības ir 25:75, savukārt augšstilba kaula epifĩzē šīs attiecības ir 50:50, bet spieḳkaula diafīzē 95: 5, attiecīgi (Eriksen, 1994).

\section{Kortikālie kauli}

Kortikālie kauli klāj kaulu virsmu un veido ārējo aizsargslāni jebkuram cilvēka skeleta kaulam. Kortikāliem kauliem raksturīga liela izturība pret mehāniskām slodzēm, kura visvairāk vajadzīga skeleta garajos stobrkaulos, ribās un galvaskausa kaulos. Kortikālo kaulu izturības 
pamatā ir osteons (Harversa sistēma), ko veido koncentriski kaula plātnīšu slāņi (lamellas) ar Harversa kanālu vidusdaḷā. Harversa kanāls nodrošina kaulaudus ar asinsapgādi (1.2.att).

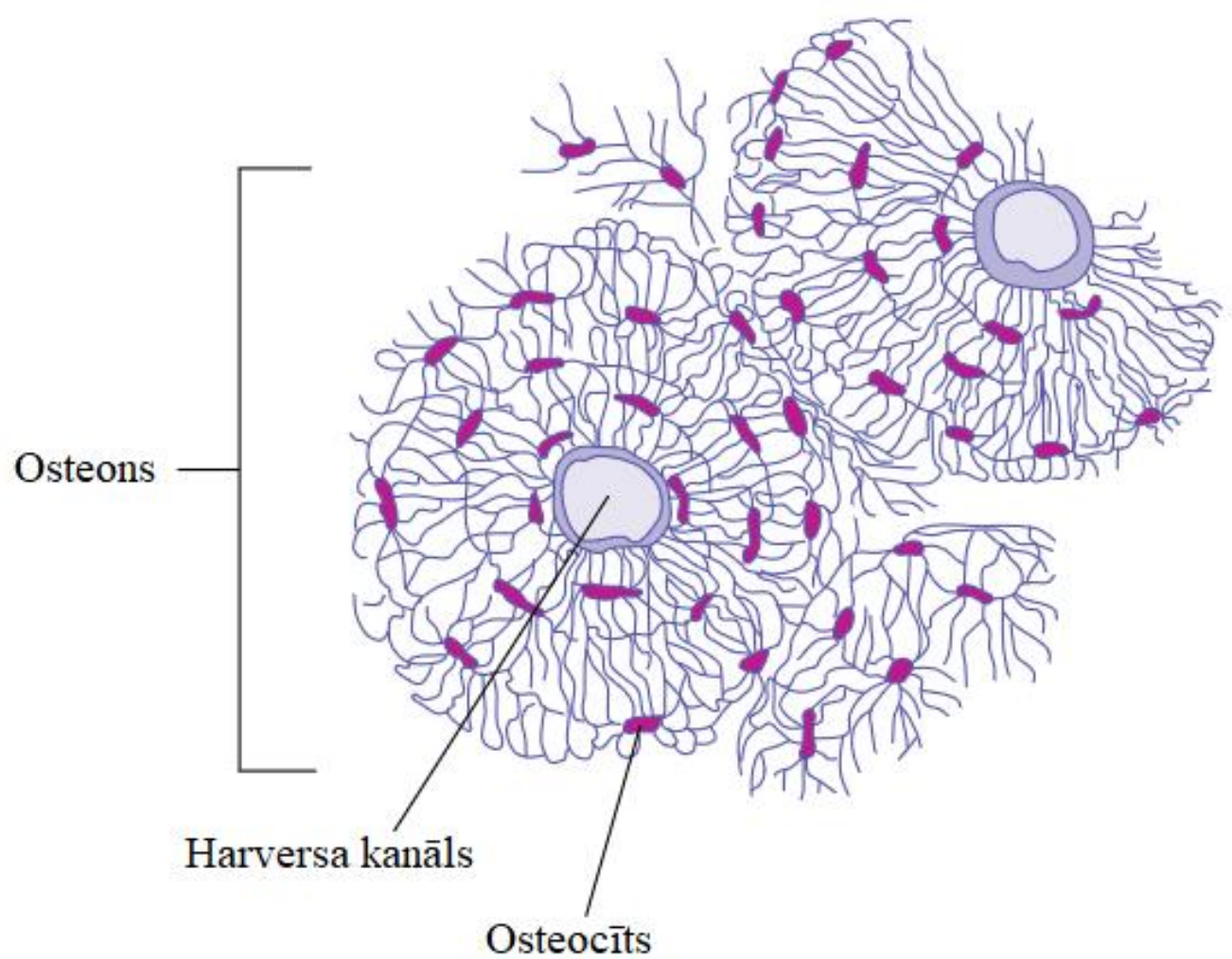

\section{2. att. Shematisks kortikālā kaula šḳēersgriezuma zīmējums}

(https://en.wikipedia.org/wiki/Osteon\#/media/File:Transverse_section_of_bone_en.svg)

Osteonam ir cilindriska forma, tas ir aptuveni 400 mm garumā un 200 mm platumā. Trabekulārā kaulā osteoni veido sazarojumu tīklu. Harversa kanāli ir novietoti kaula garenass virzienā, katru norobežo 5-20 koncentriski novietotas lamellas. Atsevišķus osteonus norobežo starpplātnītes. Gan osteona, gan starpplātnīšu pamatu veido vienā virzienā ejošas kolagēna šḳiedras, starp kurām izgulsnējas sāḷ. Blakus esošo kolagēna šķiedru virziens ir dažāds - tas padara kaulu plātnītes izturīgas. Osteoni tiek noārdīti un veidojas no jauna, piemērojoties main̄̄giem slodzes apstākḷiem. Folkmaṇa kanāli saista kopā blakusesošos osteonus. (Standring, 2015).

Kortikālam kaulam raksturīga mazāka vielmaiṇas aktivitāte, salīdzinot ar trabekulāro kaulu. Pieauguša vesela cilvēka organismā ir aptuveni $21 \times 10^{6}$ Harversa sistēmas ar $3.5 \mathrm{~m}^{2}$ kopējo platîbu. Kortikālā kaula porainība parasti ir $<5 \%$, kas atkarīgs no aktīva Harversa sistēmas remodelācijas skaita attiecībā pret neaktīvu Harversa sistēmas remodelācijas skaitu. 
Veseliem veciem pieaugušiem cilvēkiem parasti ir samazināts kortikālā kaula biezums un palielināta kortikāla kaula porainība (Clarke, 2008).

Kortikālais kauls no ārpuses pārklāts ar kaula plēvi - periostu, izṇemot locītavas, kur kauls ir pārklāts ar locītavu skrimsli. Periosts ir piestiprināts pie kortikālā kaula ārējās virsmas ar Šarpeja šķiedrām. Periostam ir svarīga loma kaula veidošanas un kaula lūzuma dzīšanas veicināšanā - tas satur asinsvadus, nervaudus osteoblastus un osteoklastus (Standring, 2015).

\section{Trabekulārie kauli}

Trabekulārā kaula kopējais virsmas laukums ir 80\% no kopējās skeleta kaulu virsmas šo kaulu vielmaiṇas aktivitāte ir lielāka, salīdzinot ar kortikāliem kauliem. Trabekulāro kaulu pamatelements ir kaulu balı̧̧̄̌ši jeb trabekulas, kas veido savstarpēji saistītu tīmekḷveida pinumu. Pusmēness formas trabekulas veido kocentriski novietotas lamellas (1.3.att).

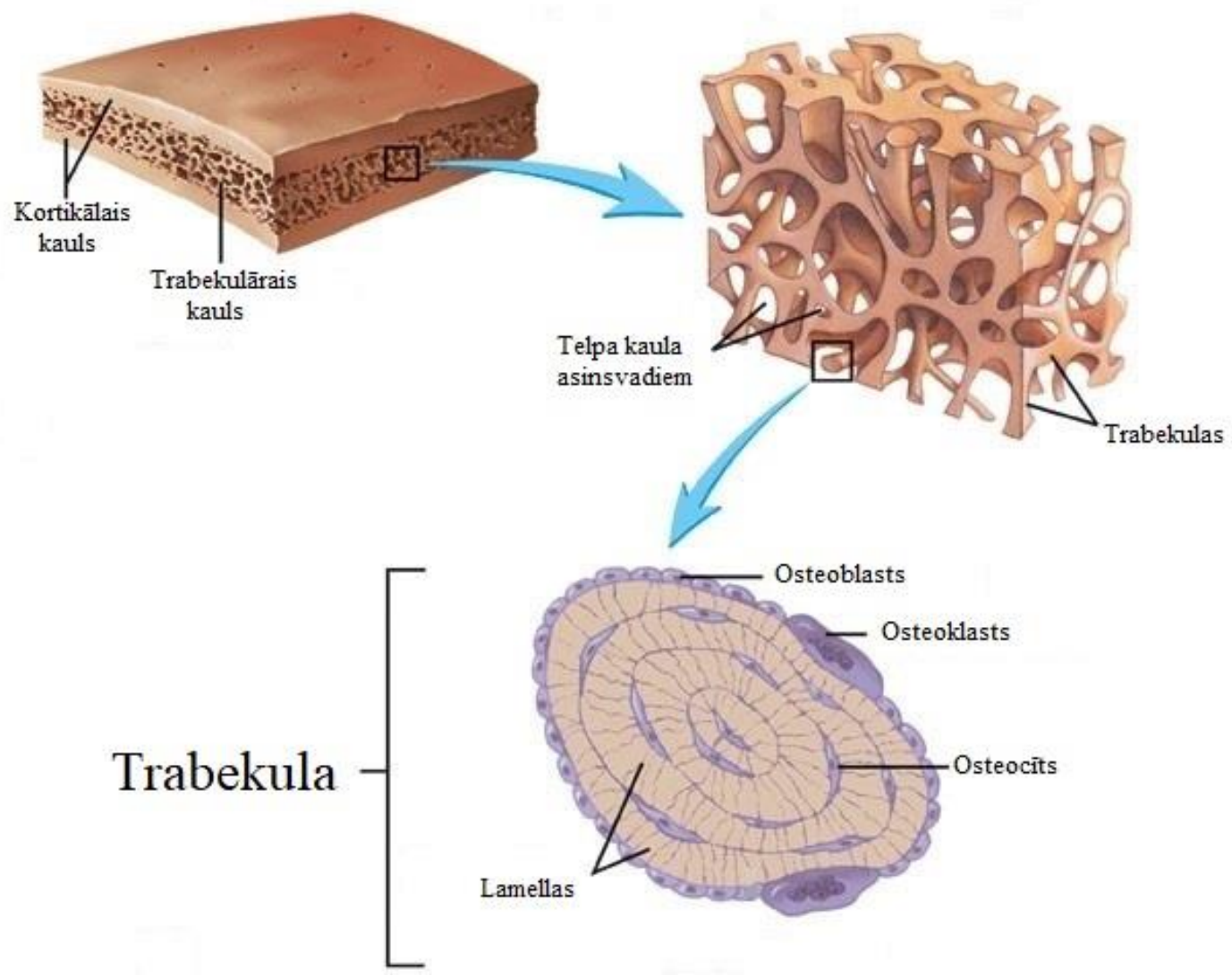

1.3. att. Shematisks trabekulārā kaula zīmējums

(http://www.biosciencenotes.com/bones)

Pieauguša vesela cilvēka organismā ir aptuveni $14 \times 10^{6}$ trabekulas ar $7 \mathrm{~m}^{2}$ kopējo platību (Clarke, 2008). Trabekulārie kauli nav tik blīvi un, pateicoties savai struktūrai, ir daudz vieglāki un elastīgāki par kortikāliem kauliem. Vislielākais trabekulāro kaulu daudzums ir garo stobrkaulu epifīzēs un metafīzēs, īsos kaulos un mugurkaula skriemeḷos (Standring, 2015). 


\section{Kaula aprite}

Kaula atjaunošana (remodelācija) cilvēka skeletā norit visu mūžu. Tiek uzskatīts, ka kaulaudi piln̄̄gi atjaunojas 10 gadu laikā, turklāt trabekulāro kaulu aprite notiek piecas līdz desmit reizes straujāk nekā kortikālo kaulu aprite. Galvenās kaula aprites funkcijas ir kaula mehāniskā stipruma saglabāšana, aizstājot vecos kaulaudus un kaulaudus, kuriem ir mikrobojājumi, ar jaunajiem, veselajiem kaulaudiem, un nodrošināt kalcija un fosfāta homeostāzi (Clarke, 2008).

Kaula aprites ciklu veido aktivācijas, resorbcijas, reversijas, kaula veidošanas un miera fāze. Šis kaula aprites cikls ilgst sešus līdz deviṇus mēnešus, bet kaula pilnīga mineralizācija tiek sasniegta aptuveni divu gadu laikā. Osteocīti organizē kaula apriti, regulējot osteoklastu un osteoblastu diferenciāciju un tādējādi kaulu resorbciju un veidošanos (Kenkre et al., 2018), (1.4. att.).

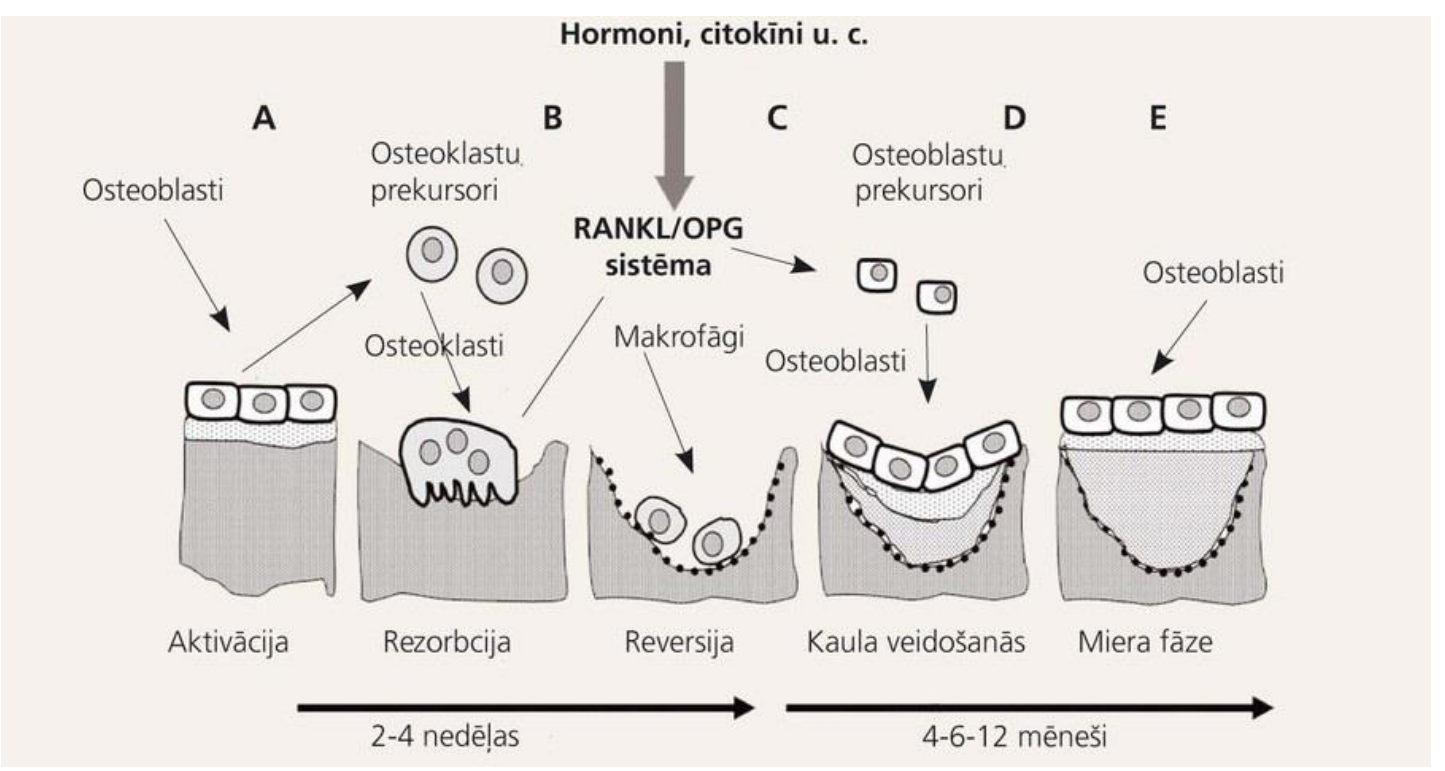

\section{4. att. Kaula aprites cikls vesela cilvēka kaulaudos: $\mathbf{A}$ - aktivācijas fāze, $\mathbf{B}$ - resorbcijas fāze, C - reversijas fāze, $D$ - kaula veidošanas fāze, $\mathbf{E}$ - miera fāze \\ (https://www.doctus.lv/2008/11/dzivam-cilvekam-dzivu-kaulu-jauni-aspekti-osteoporozes-terapija)}

\footnotetext{
Aktivācijas fāzē osteoblasti aktivē osteoklastu prekursoršūnas (preosteoklastus), veicinot to nobriešanu par pilnvērtīgiem osteoklastiem. Osteoklasti ir asinsrades šūnu izcelsme. Daudz vienkodolu šūnas saplūst un izveido daudzkodolu preosteoklastus, kas saistās ar kaula matricu, izmantojot mijiedarbību starp integrīna receptoriem preosteoklastu šūnu membrānās un RGD (argīns, glicīns un asparagīns) saturošiem peptīdiem matricas proteīnos. Novietojoties blīvi ap kaulu resorbējošo zonu, osteoklasti izolē resorbcijas vietas no apkārtējiem kaulaudiem (Roodman, 1999).
} 
Mērḳtiecīgā kaula aprite notiek, mainot bojātos vai vecos kaulaudus. Osteocītu apoptoze, ko izraisa, piemēram, kaula matricas mikrobojājums, noved pie parakrīno faktoru izdalīšanās, kas palielina lokālo angioǵenēzi un osteoklastu un osteoblastu prekursoršūnu migrāciju (Goldring, 2015). Turpretim nemērḳtiecīga kaula aprite notiek nenoteiktās vietās, reaǵējot uz sistēmiskām izmaiņām hormonos, piemēram, PTH, tādējādi ḷaujot piekḷūt kaulu kalcija krājumiem (Kenkre et al., 2018).

Resorbcijas fāzē osteoklasti izdala organiskās skābes un proteolītiskus fermentus, noārda veco kaulvielu, veidojot resorbcijas lakūnu. H+ joni skābina resorbcijas lakūnas zem osteoklastiem, izšḳīdinot kaula matrices minerālo sastāvdaḷu, kamēr katepsīns K sagremo proteīnu matrici, kas sastāv no I tipa kolagēna. Resorbcijas fāze beidzas ar osteoklastiem ieprogrammētu šūnu nāvi - apoptozi (Boyle, 2003).

RANKL, OPG, IL-1 un IL-6, CSF, PTH, 1,25 - dihidroksivitamīns D un kalcitonīns regulē osteoklastu veidošanu, aktivāciju un kaulu resorbciju. RANKL, ko sintezē osteoblasti un osteoblastu prekursoršūnas, piesaistās pie RANK receptora, kas atrodas uz osteoklastu un osteklastu prekursoršūnu virsmas, tādējādi veicinot osteoklastu nobriešanu. Magrofāgu CSF ir nepieciešams osteoklastu priekšteču proliferācijai, izdzīvošanai un diferenciācijai, kā arī kaulaudu resorbcijai. Osteoblasti un osteoblastu prekursoršūnas arī sintezē OPG. OPG ir ar šūnas membrānu saistītais proteīns, kas darbojas par konkurējošo RANKL, neḷaujot RANKL piesaistīties pie RANK receptoriem (Cohen, 2006).

Osteoklasti savienojas ar kaula matrici caur integrīna receptoriem osteoklastu membrānā, kas saistās ar kaula matrices peptīdiem. $\beta 1$ un $\alpha v \beta 3$ integrīna receptori osteoklastos saistās ar kolagēnu, fibronektīnu un laminīnu. $\alpha v \beta 3$ integrīna receptori, kas var veidot kompleksus ar osteopontīnu un kaula sialoproteīnu, veicina kaulaudu resorbciju (Ross, 1993).

Osteoklastu saskaršanās ar kaula matrici liek tiem polarizēties. Uz kaulaudu uzsūcošas virsmas attīstās viḷ,notā robeža, kas veidojas, kad pārskābinātie pūslī̌si, kas satur matrices metālproteināzi un katepsīnu K, tiek transportēti pa mikrocaurulītēm, lai saplūstu ar membrānu. Resorbējot kaulu, osteoklasti izdala $\mathrm{H}+$ jonus caur $\mathrm{H}+$ adenozītrifosfotāzes un hlorīdu kanāliem, samazinot $\mathrm{pH}$ līmeni (pH 4.5 vai zemāk) resorbcijas lakūnās, kas palīdz mobilizēt kaulu minerālvielas (Teitelbaum, 2003).

Pēc saskarsmes ar kaula matrici osteoklasta citoskeleta fibrilārais aktīns izveido aktīna gredzenu - izveidojas hermētiskas zonas, kas izolē resorbcijas lakūnas no apkārtējās kaula virsmas (Vaananen, 2000). Aktīvi resorbējošie osteoklasti veido podosomas. Podosomas sastāv no aktīna serdes, ko apņem $\alpha v \beta 3$ integrīns un saistītie citoskeleta proteīni (Clarke, 2008). 
Reversijas fāzē īpašas mononukleāras, makrofāgiem līdzīgas šūnas pabeidz kolagēna noārdīšanu un veicina augšanas faktoru izdali, kas turpmāk ierosina kaulu veidošanos. Kaulu virsmas sagatavošanu veic osteoblastu līnijas šūnas, kas noārda nemineralizētu kolagēna matricu, nekolagēna mineralizēta matrica tiek nogulsnēta, veicinot osteoblastu piesaisti (Zhou, 1994).

Pēc kaulu resorbcijas lakūnās paliek dažādas mononukleāras šūnas, ieskaitot monocītus, osteocītus un preosteoblastus, kas uzsāk jaunu kaulu veidošanu. TGF- $\beta$ koncentrācija kaulu matricā korelē ar kaula aprites histomorfometriskajiem indeksiem, osteokalcīnu un sārmaino fosfotāzi. No kaulu matricas atbrīvotais TGF- $\beta$ samazina osteoklastu kaulu resorbciju, kavējot osteoblastu RANKL producēšanu (Smit et al., 2002).

Kaula veidošanās fāzē no mezenhimālām cilmes šūnām attīstās kaulveides šūnas osteoblasti, kas resorbcijas lakūnu aizpilda ar jaunu kaulvielu. Osteoblasti sintezē un izdala I tipa kolagēna bagātu osteoīdu matricu un spēlē lomu osteoīdu mineralizācijas regulēšanā (Atkins et al., 2012). Kaulu mineralizācijas process, kurā hidroksiapatīta kristāli tiek nogulsnēti kolagēna fibrillās, ir sarežǵīts, un tā regulācija nav līdz galam saprotama. Kontrole tiek veikta ar sistemātisku kalcija un fosfāta koncentrācijas regulēšanu, lokālu kalcija un fosfāta koncentrāciju ārpusšūnu matricas pūslīšos un ar vietējiem mineralizācijas inhibitoriem, ieskaitot pirofosfātu un kollagenozos olbaltumvielas, piemēram, osteopontīnu. Neorganiskā pirofosfâta un fosfāta attiecība ir kritisks mineralizācijas regulators un audu nespecifiskās sārmainās fosfatāzes un ektonukleotīdu pirofosfatāzes relatīvās aktivitātes ir galvenie šīs attiecības noteicošie faktori (Cui et al., 2016).

Miera fāzes laikā notiek pilnīga jaunveidotā kaula mineralizācija. Kad mineralizācija ir pabeigta, osteoblasti tiek pakḷauti apoptozei vai diferencējas par osteocītiem. Osteocītiem ir galvenā loma kaula aprites beigu noteikšanai, izdalot osteoǵenēzes antagonistus, piemēram, Wnt signalizācijas ceḷa antagonistu - SOST (Bonewald, 2011).

Kaula aprites cikls ir stingri regulēts, lai panāktu līdzsvarotu kaulu resorbciju un veidošanu. Kamēr sistēmiski atbrīvotiem faktoriem ir regulējoša loma, tāds fakts, kā kaula aprite notiek vienlaicīgi vairākās anatomiski atšķirīgās vietās, norāda, ka vietējiem regulējošiem faktoriem ir kritiska nozīme līdzsvara sasniegšanai. Divi galvenie signalizācijas ceḷi - RANKL/RANK/OPG un Wnt veido sistēmiskus un lokālus signālus. Signalizācijas ceḷu regulējoša loma kaula resorbcijas un veidošanās līdzsvara uzturēšanai padara tos par potenciāli nozīmīgiem farmakologiskās iejaukšanās mērḳiem, piemēram, osteoporozes gadījumā (Kenkre et al., 2018). 


\section{RANKL/RANK/OPG signalizācijas ceḷ̌s}

CSF-1 normālos apstākḷlos stimulē osteoklastu darbību. Osteoblasti un osteoblastu prekursori producē divus RANKL veidus. Ar membrānu saistītais RANKL tieši mijiedarbojas ar membrānu saistītām RANK molekulām uz blakus esošā osteoklasta prekursora virsmas. sRANKL tiek atbrīvots no osteoblastiem vai osteoblastu prekursoriem, izkliedējas starpšūnu telpā un mijiedarbojas ar pie membrānas piesaistītajām RANK molekulām uz blakus esošā osteoklastu prekursora virsmas. OPG neḷauj RANKL vai sRANKL mijiedarboties ar RANK. RANKL un OPG attiecības, ko ražo osteoblasti un osteoblastu prekursori kontrolē RANKL stimulētu osteoklastoǵenēzi (1.5. att.).

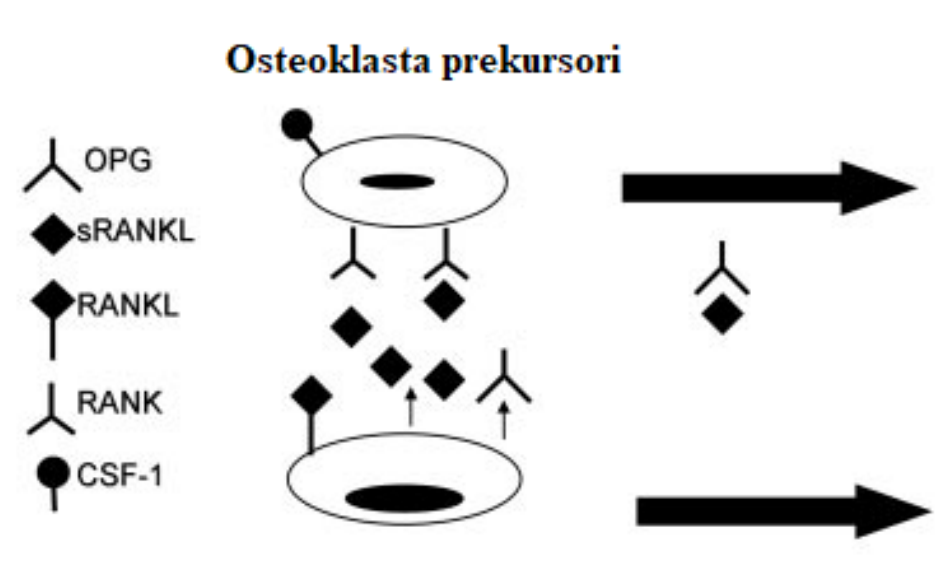

Osteoblasta prekursori

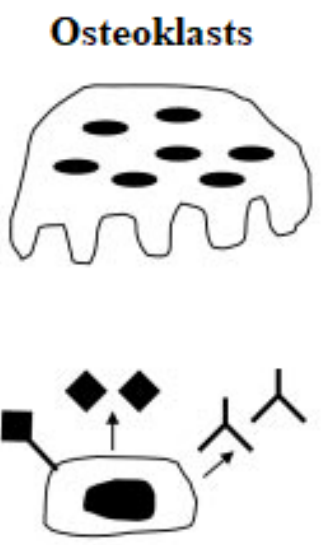

Osteoblasts

\section{5. att. Osteoklastoǵenēzes regulācija ar RANKL un OPG}

(Clarke, 2008)

\section{Wnt signalizācijas ceḷ̌s}

Wnt signalizācijas ceḷu iedala $\beta$-katenīna atkarīgā (kanoniskā) un $\beta$-katenīna neatkarīgā (nekanoniskā) ceḷā. Pētījumos par retām cilvēku slimībām ar ekstremāliem kaulu masas fenotipiem tika atklāts, ka kanonisks Wnt signalizācijas ceḷš ir galvenais osteoblastiska kaula veidošanas regulators (1.6.att.). 

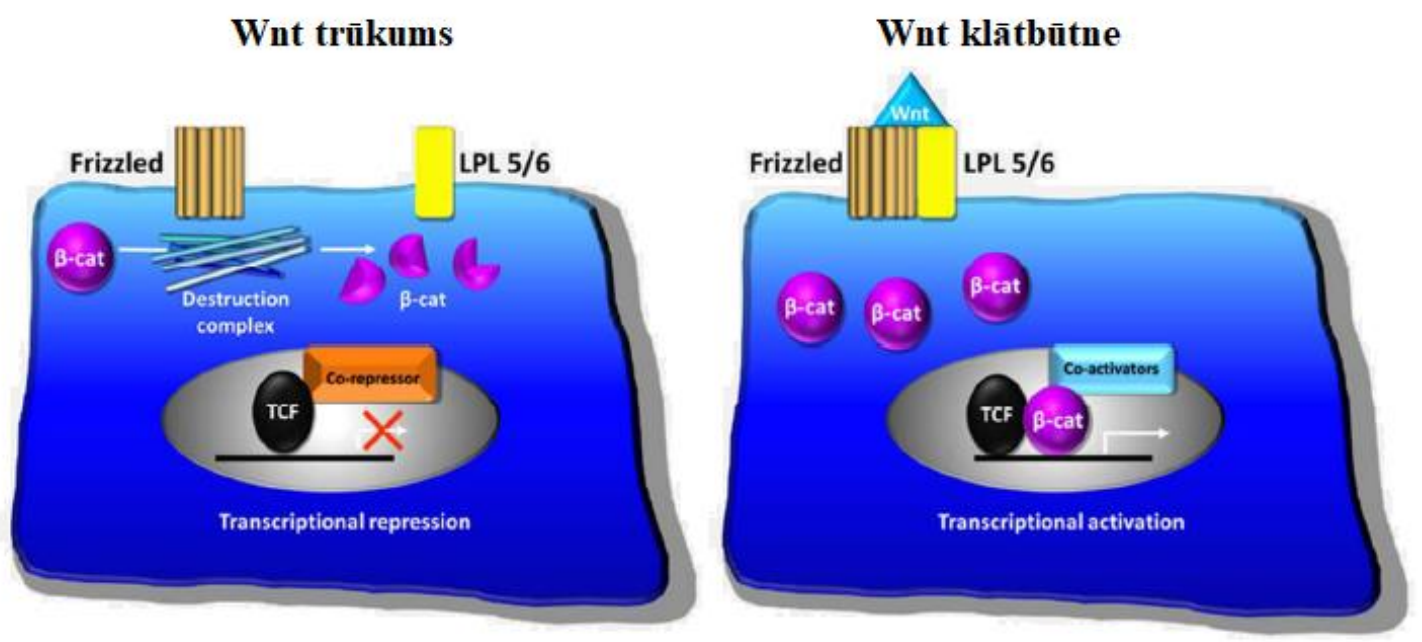

1.6. att. Kanoniskā Wnt signalizācijas cẹ̦a shēma. Bez Wnt proteīna, Frizzled un LPL5/6 receptori nesadarbojas. Destrukcijas komplekss, kas atrodas šūnas citoplazmā, noārda $\beta$-katenīnu un mērḳa gēna ekspresija tiek pārtraukta. Wnt proteīna klātbūtnē Frizzled receptors saistās LPL5/6 receptoru un bloḳē destrukcijas kompleksa darbību. $\beta$-katenīns uzkrājas šūnas citoplazmā, pārvietojas uz kodolu, aizvietojot transkripcijas korepresoru ar koaktivatoru. Koaktivatori palielina mērḳa gēnu ekspresiju, kas iesaistīti osteoblastu diferenciācijā

(Kenkre et al., 2018)

Pacientiem ar osteoporozes pseidogliomas sindromu LPL 5 receptoru funkciju mutācijas zuduma dēḷ tiek traucēta Wnt signalizācija un osteoblastiska kaula veidošana, kā rezultātā veidojas zems kaula masas fenotips (Baron et al., 2013). Wnt inhibitors, SOST, tika atklāts, pētot reti sastopamas slimības, kur ir palielināta kaula masa, sklerosteozi un Van Buchema slimību. Miera fāzes laikā osteocīti producē SOST, kas saistas ar LPL 5/6 receptoriem (Clevers et al., 2012). SOST un DKK-1/2 novērš turpmāku kaulu veidošanos. Kaula aprites cikla laikā Wnt inhibitoru ekspresija samazinās, l,aujot osteoblastiem veidot kaulu. Miera fāzes laikā jaunizveidoti osteocīti tiek iespiesti kaulu matricā, atkārtoti producējot Wnt inhibitorus, kā rezultātā tiek pārtraukta kaula veidošanās (Bonewald, 2011).

\section{Kaula mineralizācija}

Kaula sastāvā ir 50-70\% minerālvielu, 20 - 40\% organisko vielu, 5 - 10\% ūdens un 3\% lipīdu. Minerālvielas, kas ietilpst kaula sastāvā, galvenokārt ir hidroksiapatīts $\left[\mathrm{Ca}_{10}\left(\mathrm{PO}_{4}\right)_{6}(\mathrm{OH})_{2}\right]$, neliela daudzuma karbonāts, magnijs un skābā fosfātāze ar trūkstošām hidroksilgrupām. Matricas nobriešana ir saistīta ar sārmainās fosfatāzes un nekolagēna proteīna, t. sk. osteokalcīna, osteopontīna un kaulu sialoproteīna producēšanu. Uzskata, ka kalciju un fosfātu saistošie proteīni palīdz regulēt minerālvielu nogulsnēšanos, regulējot izveidoto hidroksiapatīta kristālu lielumu un daudzumu (Clarke, 2008). 
Kaula minerālvielas nodrošina kaulu mehānisko izturību uz spiedi, savukārt organiskā matrica nodrošina elastību un lokanību. Kaula minerālvielas sākotnēji nogulsnējas dobumos starp kolagēna šķiedru galiem (Landis, 1995). Hondrocīti un osteoblasti sintezē ārpusšūnu matricas pūslīšus, nodrošinot mikrovidi, kurā kalcija un fosfăta koncentrācija var palielināties, lai paātrinātu kristālu veidošanos. Ārpusšūnu šķidrums parasti nav pārsātināts ar hidroksiapatītu, tāpēc hidroksiapatīts spontāni nenogulsnējas. Ārpusšūnu matricas pūslīši satur kodolu serdi, kas sastāv no proteīniem un skābo fosfolipīdu, kalcija un neorganiskā fosfāta kompleksa, kas ir pietiekams kalcija hidroksiapatīta kristālu nogulsnēšanai. Pagaidām nav skaidrs, kā ārpusšūnu matricas pūslīši veicina mineralizāciju kolagēna šķiedru galos (Anderson, 2003).

Nav pierādīts, ka nekristāliska kalcija fosfāta klasteri kā amorfs kalcija fosfāts veidotos kaulos pirms tā pārveidošanās kalcija hidroksiapatītā (Weiner, 2005). Kalcija hidroksiapatîta kristālu palielināšanās notiek gan ar kristālu augšanu, gan ar kristālu apvienošanos. Makromolekulas saistās ar augošo kristālu virsmām, lai noteiktu kristālu izmēru, formu un skaitu.

Apstiprinātie mineralizācijas veicinātāji (nukleātori) ir dentīna matricas proteīns I un kaula sialoproteīns. Fosfoproteīnkināze un sārmainā fosfatāze regulē mineralizācijas procesu. Kaulaudu sārmainā fosfatāze var palielināt lokālo fosfora koncentrāciju, noṇemt fosfātus saturošus hidroksiapatīta kristālu augšanas inhibitorus vai modificēt fosfoproteīnus, lai kontrolētu to spēju darboties kā nukleātori (Clarke, 2008).

\subsection{Kaula aprites cikla endokrīna regulācija}

\section{Paratireoīdais hormons}

Atkarībā no PTH iedarbības laika var būt pretējais efekts uz kaula aprites ciklu. Nepārtraukta PTH sekrēcija stimulē kaulu resorbciju, kas ir galvenais kalcija homeostāzes uzturēšanas mehānisms asin̄̄s. Turklāt ilgstoša PTH iedarbība primārā hiperparatireoidisma gadījumā, kas rodas epitēlijḳermenīšu adenomas vai hiperplāzijas dēḷ, izraisa hiperkalciēmiju, kaula zudumu un palielinātu lūzumu risku. Nepārtraukta PTH sekrēcija izraisa kortikālā un trabekulārā kaula zudumu, savukārt kortikālā kaulā zudums ir lielāks. Šis kataboliskais efekts ir RANKL/RANK/OPG signalizācijas ceḷa iedarbības dēḷ. Nepārtraukta PTH sekrēcija palielina RANKL un kavē OPG, stimulējot osteoklastoǵenēzi. MCP - 1, kas ir atbildīgs par osteoklastu prekursoru atlasi un diferenciāciju, arī palielinās liekā PTH daudzuma dēl, un, domājams, ir nozīme pacientiem ar primāru hiperparatireozi. 
Turpretī “intermitējošai” PTH iedarbībai ir anabols efekts, kas tiek izmantots osteoporozes ārstēšanā. Periodiskā PTH receptoru stimulēšana uzlabo kaulu veidošanos, izmantojot modulāciju caur Wnt signalizācijas ceḷu, samazinot SOST un DKK-1 ekspresiju, vienlaikus palielinot Wnt ligandu Wnt10b. Kanoniska Wnt signalizācija palielina osteoblastoǵenēzi, mērķa gēnu ekspresiju un kaulu veidošanu (Kenkre et al., 2018).

\section{D vitamīns}

Kaula matrices mineralizācija netieši tiek stimulēta ar D vitamīnu. UV ietekmē ādā veidojas vitamīna D neaktīvā forma, kas pēc tam aktivējas aknās un nierēs. Aknas sintezē D 25-hidroksiholesterolu, un nieres pēc tam producē bioloǵiski aktīvo 1,25 $(\mathrm{OH})_{2}$ vitamīnu, kas ir atbildīgs par atbilstošu kalcija un fosfora koncentrāciju serumā, ḷaujot nemineralizētajai kaula matricei pasīvi mineralizēties (Weiner et al., 2005).

1,25 $(\mathrm{OH})_{2}$ vitamīns D regulē kalcija un fosfātu uzsūkšanos zarnās, nodrošinot substrātu kaulu mineralizācijai. Ca absorbcija tievā zarnā notiek aktīvā veidā, iesaistot kalbindīnu kalciju saistošo olbaltumvielu. Kalbindīns atrodas uz tievas zarnas gḷotādas virsmas un, pateicoties augstai spējai saistīties ar kalcija joniem, atvieglo to transportēšanu šūnās. Pasīvā kalcija uzsūkšanās notiek caur enterocītu spraugām pasīvās difūzijas veidā (Yang et al., 2018). Tomēr 1,25 (OH $)_{2}$ vitamīna D fiziologiiskā loma kaula aprites ciklā paliek neskaidra. Vairākos pètījumos ziņots par D vitamīna receptoru ekspresiju osteoklastos, osteoblastu prekursoros un osteocītos, kas liek domāt, ka D vitamīnam var būt arī tieša ietekme uz kaulu. Vitamīna D receptoru ekspresija ir pierādīta cilvēka osteoklastu prekursoros, bet pētījumi par D vitamīna receproru ekspresiju nobriedušos osteoklastos ir pretrunīgi. Līdzịgi osteoblastu prekursori ekspresē vitamīna D receptorus, bet nobriedušiem osteoblastiem vitamīna D ekspresiju var noteikt tikai zemā līmenī. Turklāt in vitro pētījumi parādīja $\mathrm{D}$ vitamīnu aktivizējošā enzīma $1 \alpha$ hidroksilāzes aktivitāti cilvēka osteoblastiem, osteoklastiem un mRNS ekspresiju osteocītos, kas norāda uz iespējamo lokālo D vitamīna aktivitātes regulēšanu skeleta šūnās (Lanske et al., 2014).

\section{Kalcitonīns}

Kalcitonīns tiek sintezēts vairogdziedzera C-šūnās. Kalcitonīna sekrēcija galvenokārt ir atkarīga no kalcija līmeņa asinīs. Akūta kalcija koncentrācijas paaugstināšanās stimulē hormona sekrēciju. Tomēr pastāvīga hiperkaciēmija ātri noved pie parafolikulāro šūnu tahifilakses, kā rezultātā kalcitonīna sekrēcija netiek uzturēta. Farmakoloǵiskā koncentrācijā kalcitonīns kavē kaulu resorbciju. Hormons darbojas caur kalcinotīna receptoriem osteoklastos, samazinot osteoklastu skaitu un aktivitāti (Carter et al., 2006). Tiek uzskatīts, ka kalcinotīnam 
ir stimulējoša iedarbība uz osteoblastiem, veiconot kaulaudu veidošanu. Par to liecina kalcinotīna receptoru esamība uz osteoblasta virsmas (Bandeira et al., 2016).

\section{Vairogdziedzera hormoni}

Tirotoksikoze ir sekundāras osteoporozes cēlonis, kas ir saistīts ar palielinātu osteoblastiska kaula veidošanu un palielinātu osteoklastisku kaula resorbciju. Trijodtironīns tiešā veidā stimulē osteoblastu diferenciāciju un kaulu mineralizāciju, bet nav pierādīts, ka vairogdziedzera hormoni tiešā veidā ietekmē osteoklastus. Trijodtironīna deficīts izraisa kaula aprites cikla pagarināšanu ar zemu kaulu vielmaiņas aktivitāti un palielinātu kaulu masu. Savukārt hipertireoze palielina kaulu vielmainas aktivitāti, samazina kaula aprites cikla ilgumu, zaudējot 10\% no kaulu masas katrā aprites ciklā (Basset et al., 2016)

\section{Augšanas hormons un IGF-1}

Augšanas hormons ir peptīdhormons ar anabolisku efektu, kuru organismā producē hipofizzes priekšējā daiva. Augšanas hormons inducē IGF-1 ekspresiju, palielina kaulu vielmaiņu, stimulējot gan osteoblastu proliferācijas aktivitāti, gan osteoklastisku kaula resorbciju. Tomēr osteoblastiska kaula veidošana dominē, kas noved pie neliela kaula masas pieauguma. Savukārt augšanas hormona deficīta gadījumā kaula resorbcija pārsniedz kaula veidošanu, izraisot osteoporozi (Kenkre et al., 2018).

\section{Glikokortikoīdi}

Glikokortikoīdos hormonus cilvēka organismā sintezē virsnieru garozas pavedienu zonas (zona fasciculata) šūnas. Suprafiziologiiskās devās glikokortikoīdi izraisa osteoporozi. Glikokortikoīdi kavē osteoblastu diferenciāciju un darbību, palielinot osteoblastu apoptozi. Turpretī glikokortikōidi palielina osteoklastisku kaula resorbciju, samazinot OPG un palielinot osteoblastu RANKL ekspresiju un osteoklastu RANK ekspresiju. Tomēr pastiprināta kaulu resorbcija ir tikai īslaicīga, un ilgstošas glikokortikoīdu ārstēšanas rezultātā notiek osteoklastu skaita un kaula resorbcijas samazināšanās. Pētījumos ir pierādīts, ka glikokortikōidiem fiziologiskā koncentrācijā ir anaboliska iedarbība uz kaulu vielmaiņu (Mitra, 2011).

\section{Dzimumhormoni}

Pēcmenopauzes osteoporozi raksturo paaugstināta osteoklastiska kaula resorbcija attiecībā pret osteoblastiskas kaula veidošanās, kā rezultātā veidojas kaulu vielas zudums. Estrogēni, kas darbojas caur estrogēna $\alpha$ receptoriem, kavē kaulu resorbciju, samazinot osteoklastu skaitu, aktivitāti un palielinot osteoklastu apoptozi. Estrogēni arī nomāc osteoblastu un osteocītu apoptozi, lai veicinātu kaula veidošanu, ierobežojot kaula apriti (Khosla et al., 2012). 
Aromatāze - ferments, kas pārveido testosteronu estradiolā, pārsvarā atrodas tauku audos. Aromatāze pārveido androgēnus par estrogēniem un sievietēm pēcmenopauzes periodā virsnieru sterōidi ir vienīgais estrogēna avots. Tādējādi samazinātas aromatāzes darbības dēl sievietēm ir paaugstināts osteoporozes risks. Līdzīgi, aromatāzei ir svarīga loma kaula masas sasniegšanā vīriešiem. Ir pierādīts, ka estrogēna, nevis androgēna līmenis nosaka kaulu masu novecojošā vīriešu populācijāa (Santen et al., 2009).

Androgēni, tāpat kā estrogēni, stimulē kaulu veidošanu un inhibē kaulu resorbciju. Zems androgēnu līmenis vīriešiem palielina kaula aprites àtrumu, kas ir arī tāpēc, ka no testosterona tiek aromatizēts mazāk estrogēna (Vanderschueren et al., 2008).

\subsection{Kaula aprites cikla parakrīna regulācija}

\section{Augšanas faktori}

TGF $\beta$ un BMP ir TGF $\beta$ gimenes locekḷi, kas atrodas kaulu matricā un signalizē caur kanoniskiem (Smad) un nekanoniskiem (no Smad neatkarīgiem) cel̦iem. TGF $\beta$ un BMP izraisa RUNX 2 ekspresiju, kas nepieciešams osteoblastu diferenciācijas uzsākšanai. TGF $\beta 1$ inducē mezenhimālo cilmes šūnu migrāciju uz kaulu resorbcijas vietām (Bruderer et al., 2014).

\section{Prostaglandīni}

Prostaglandīni lokāli darbojas caur vairākiem G-olbaltumvielu saistītiem receptoriem, lai regulētu kaula resorbciju un veidošanu, bet precīza prostaglandīnu loma kaula aprites ciklā joprojām paliek neskaidra. Prostaglandīns $E_{2}$ (PGE2) ir spēcīgs kaulu resorbcijas stimulators, domājams, ka tas darbojas, palielinot RANKL/OPG attiecības, lai uzlabotu osteoklastoǵenēzi. PGE2 arī stimulē osteoblastu proliferāciju un diferenciāciju, palielināto kaulu veidošanos. Tiek uzskatīts, ka pretējā PGE2 iedarbība veidojas caur dažādiem G-olbaltumvielu receptoriem un sekundārajiem izziṇas ceḷiem (Blackwell et al., 2010).

\section{Citokīni}

Citokīni, piemēram, IL-1 un IL-6, un TNF $\alpha$ var stimulēt osteoklastoǵenēzi, turpretī citi, piemēram, IL-4 un gamma interferons, kavē osteoklastu veidošanos. Sievietēm pēcmenopauzes periodā šiem citokīniem ir nozīmīga loma osteoporozes patofiziologijā. Estrogēna deficìta dēl palielinās IL-1, IL-6 un TNFa, kā rezultātā paaugstinās RANKL ekspresija, palielinās osteoklastoǵenēze un kaulu resorbcija (Pacifici, 1996). 


\subsection{Kaula aprites cikla novirzes osteoporozes laikā}

Veselo pieaugušo cilvēku kaula aprites ciklam ir cieša saikne starp kaula resorbciju un kaula veidošanu. Vairākas metabolas kaulu slimības, tai skaitā osteoporoze, raksturojas ar šo saikņu pazušanu (Feng et al., 2011).

Osteoporoze ir biežākā kaulu metabolisma slimība, un no tās izrietošie trauslo kaulu lūzumi ir saistīti ar paaugstinātu saslimstību un mirstību; osteoporozes izplatība Eiropā ir 27,6 miljoni un 1 no 3 sievietēm un 1 no 5 vīriešiem virs 50 gadiem cieš no osteoporotisko kaulu lūzumiem (Hernlund et al., 2013). Osteoporozi var diagnosticēt pēc trauslu kaulu lūzuma vai ar duālās enerǵijas rentgena absorbciometrijas (osteodensitometrijas) palīdzību. Zinātniskos nolūkos ir izstrādātas arī datortomogrāfiskā kvantitatīvā tomogrāfija un magnētiskās rezonanses kvantitatīvā tomogrāfija. 1970. gados tika ierosināts izmantot kvantitatīvo datortomogrāfiju kaulu minerālā blīvuma novērtēšanai. Neskatoties uz tā uzticamību un precizitāte, tehniski trūkumi (prasības lielai jonizējošā starojuma devai un salīdzinoši ilgs skenēšanas laiks) ierobežoja datortomogrāfijas izmantošanu, un osteodensitometrija kḷuva par zelta standarta kaula minerālblīvuma novērtēšanas metodi. Datortomogrāfijas tehnolog̣ijas attīstība ir samazinājusi tās iepriekšējos ierobežojumus, un kaulu kvalitātes novērtēšana ar datortomogrāfijas palīdzību tagad arī ir pielietojama klīniskajā praksē (Brasileiro et al., 2017).

Spirāles datortomogrāfijas iekārtas ir konusa stara datortomogrāfijas (KSDT) pirmsākums. Būtiskā atšķirība starp KSDT un spirāles datortomogrāfijas ir tāda, ka KSDT izmanto konusa formas staru un laukuma detektoru, kas uzņem visu attēla apjomu vienā pagriezienā, un pacienta kustība nav nepieciešama. Savukārt spirāles datortomogrāfijas izmanto šauru, vēdekḷveida formas staru un lineāras grupas detektoru. Pacients nepārtraukti pārvietojas rentgentelpā, kamēr rentgenstars rotē ap pacientu. KSDT attīstība ir liels ieguvums gan pacientiem, gan speciālistiem, jo salīdzinājumā ar spirāles datora tomogrāfijas iekārtām, KSDT dod mazāku apstarojumu pacientam, ir lētāka, kā arī nepieciešama mazāka telpa. Kaula minerālblīvuma novērtēšanai audu radiologiskais blīvums tika mērīts Haunsfîlda vienībās (Kumar et al., 2015).

Osteodensitometrijas rezultātus atbilstoši starptautiskajām un Latvijas vadlīnijām izvērtē pēc T skalas rādītājiem. Normāls kaulu minerālais blīvums (KMB) - ja rādītājs T skalā ir līdz -1 standarta deviācijai (SD). Pazemināts KMB jeb osteopēnija ir, ja rādītājs T skalā ir no -1 līdz -2,5 SD. Osteoporoze ir, ja rādītājs T skalā ir lielāks par -2,5 SD. Par smagas pakāpes osteoporozi uzskata tādu, kuras rādītājs T skalā ir -2,5 SD un lielāks, un ja tā ir vienlaikus kopā ar diagnosticētu vienu vai vairākiem kaulu lūzumiem minimālu traumu gadījumā (Kanis et al., 2019). 
Na et al. savā pētījumā novērtēja saistību starp galvaskausa pieres kaula HU vērtībām un T rādītājiem pie mugurkaula jostas daḷas vai augšstilba kaula kakliṇa. Tika atklāta korelācija starp galvaskausa HU un sistēmisko KMB. Autors secināja, ka galvaskausa datortomogrāfija var dot iespēju atklāt osteoporozi, un pacienti, kuriem HU vērtība ir $<610$, var tikt apsvērti turpmākai iespējamās osteoporozes novērtēšanai (Na et al., 2018).

Osteoporoze var būt par iemeslu nespējai sasniegt normālu kaula masas daudzumu augšanas laikā un relatīvam kaulu resorbcijas pieaugumam vai kaulu veidošanās samazinājumam pieaugušiem cilvēkiem. Osteoporozi var definēt kvalitatīvi kā kaulu masas un stipruma samazināšanās, kas izraisa palielinātu kaula lūzuma risku (Kanis et al., 1994). Primārā osteoporoze ir visizplatītākā osteoporozes forma, un tā ietver pēcmenopauzes perioda un ar vecumu saistītu osteoporozi. Turpretī sekundārā osteoporoze ir sistēmiskas slimības vai farmakologiiskas iejaukšanās sekas. Biežākie sekundārā osteoporozes cēloṇi ir ārstēšana ar glikokortikō̄diem un imobilizācija (Reid, 2013). Kaut arī osteoporozei ir daudz un dažādu iemeslu, palielināta kaulu resorbcija attiecībā pret kaulu veidošanos ir galvenais osteoporozes patofiziologijas mehānisms. Mikroskopiskas osteoklastisko kaulu resorbcijas vietas nepilnīgi atjaunojas ar jaunizveidotu kaulu, kā rezultātā progresē kaulu zudums un palielinās kortikālā kaula porainība (Raisz, 2005). Sākotnēji osteoporoze galvenokārt var ietekmēt trabekulāro kaulu tā lielākās platības dēḷ. Neskatoties uz to, tiek ietekmēts arī kortikālais kauls, un tā pieaugošā porainība ir saistīta ar kaula lūzuma risku (Bjornerem, 2016).

\subsection{Osteoporotiskā trabekulārā kaula izmaiṇas}

Pētot kaulus ar augstu osteoporotisku lūzumu risku, tika atklāts, ka trabekulārā kaula minerālblīvums un mikrostruktūra nav viendabīga. Piemēram, augšstilba kaula proksimālā epifīzē Ward trijstūris, kas lokalizējas starp augšstilba kaula kakliṇu un lielo grozītāju, ir zema KMB rajons, bet primārās kompresijas trabekulas, kas lokalizējas augšstilba kaula galvā un kakliņā, ir augsta KMB un spēcīgas mikrostruktūras rajons (1.7. att.). 


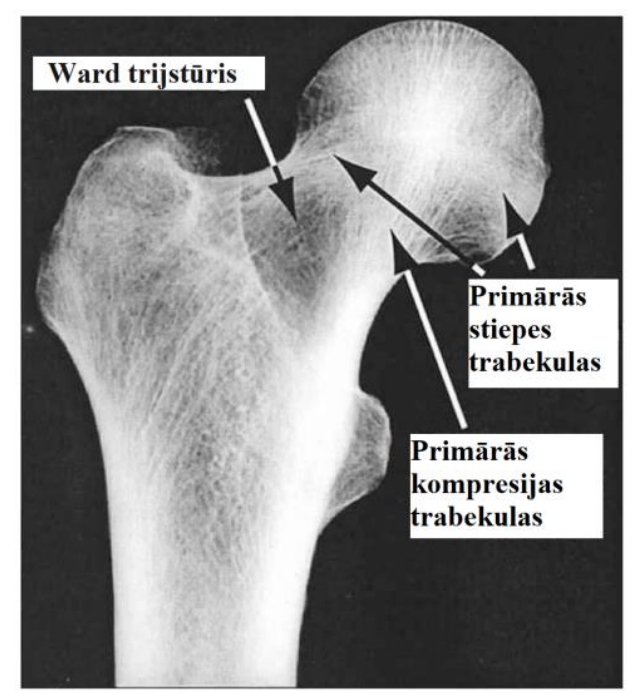

\section{7. att. Augšstilba kaula proksimālās epifīzes frontāls rentgenuzṇēmums (Osterhoff et al., 2016)}

KMB un mikrostruktūra arī nav vienādas mugurkaula skriemeḷa ķermenim. Kaula tilpuma frakcija un KMB ir vislielākais skriemeḷa ķermeņa rajonos, kuras ir vistuvāk gala plāksnēm, un skriemeḷa ķermeņa aizmugurējā un sānu rajonos. Trabekulārā kaula separācijas apjoms un anizotropijas pakāpe ir visaugstākās skriemeḷa ķermeņa centrālā un priekšējā rajonos (Hulme et al., 2007). Priekšèja ḳịla lūzums ir visbiežākais skriemeḷu lūzuma veids, un tā cēlonis ir relatīvi zems KMB un augsta anizotropijas pakāpe skriemeḷu priekšējā rajonā (Oda et al., 1998). Turklāt skriemeḷa KMB un arhitektūras telpiskās izmaiņas mainās atkarībā no vecuma un ar starpskriemeḷu disku deǵenerāciju. Ar vecumu vislielākais kaulu zudums notiek skriemeḷu ķermeņa rajonos, kas atrodas tuvāk gala plāksnēm, nekā centrālajos rajonos - kā rezultātā KMB sadalījums ir vienmērīgāks, bet dati liecina, ka daudziem gados vecākiem cilvēkiem KMB sadalījums joprojām paliek nevienmērīgs (Thomsen et al., 2002).

Augšstilba un skriemel̦u audu arhitektūras un KMB neviendabīgums ir galvenais iemesls, kāpēc vidējais KMB izskaidro tikai 60\% no visa kaula izturības (Crawford et al., 2003). Biomehāniskie pētījumi apstiprina hipotēzi, ka kaulu mehāniskai izturībai ir svarīga neviendabība. Pētījumā, kurā tika izmantots augšstilba kaula modelis, atklāja, ka KMB palielināšanās diezgan mazā rajonā $(\sim 5 \mathrm{~cm} 3)$ augšstilba kakliṇā var radīt relatīvi lielāku kaulu stipruma palielināšanos, salīdzinot ar vienmērīgu visa KMB palielināšanos (Oden et al., 1999).

Ir dažādi viedokḷi par mehānismiem, ar kuriem lokālas KMB un mikrostruktūras izmaiņas ietekmē kaulu izturību. Pētījumos ar izgrieztiem trabekulāro kaulu paraugiem tika atklāts, ka kaula kompresijas spējas samazināšanās sākas rajonos ar mazu kaula tilpuma frakciju un ka lielākas atškkirības parauga trabekulārā kaula biezumā un audu īpašībās ir saistītas ar zemāku elastības moduli (Yeh et al., 1999; Jaasma et al., 2002). Pētîjumā ar nelieliem cilvēka 
skriemeḷu paraugiem tika secināts, ka palielināta tilpuma frakcijas neviendabība skriemeḷu centrālā daḷā ir saistīta ar samazinātu kompresijas stiprību (Kim et al., 2007). Turpretī jaunākos pētījumos atklāts, ka palielināta starpskriemeḷu KMB neviendabība ir saistīta ar palielinātu skriemeḷu izturību (Hussein et al., 2013).

Ideālā gadījumā jābūt neviendabīguma rādītājiem, kuriem būs biomehāniskais pamats. Piemēram, paaugstināta skriemeḷu neviendabība var radīt lielāku mugurkaula izturību, ja š̄ neviendabība rodas no skriemeļu rajoniem ar augstu KMB skriemeḷu ķermenī. Lielāka strukturāla neviendabība varētu būt izdevīga, ja KMB īpašais telpiskais sadalījums atbilst tam, ka slodze tiek sadalīta visā skriemeḷa ḳermenī. Mērījumi parādīja, ka taisnās mugurkaula pozās mazāk nekā puse no kopējās slodzes, kas tiek uzlikta uz skriemeḷu ķermeniem, tiek sadalīta pa priekšējo pusi un ka šī frakcija samazinās ar vecumu. Mugurkaulu skriemeḷu ḳermeṇiem ar lielāku KMB aizmugurē nekā priekšpusē sagaidāms, ka slodzes sadalījumā būs lielāka izturība. Turklāt ir parādījusies hipotēze, ka starpskriemeḷu disku deǵenerācija noved pie tā, ka lielākā daḷa no slodzes tiek pārnesta uz mugurkaula ķermeņa ārējiem reǵioniem, tādējādi izraisot resorbciju centrālajā un vidējā šķērsvirziena rajonos. Skriemeḷu lūzuma risks, kuriem tika veikta šī veida adaptācija,varētu būt mazāks (Polikeit et al., 2004).

N̦emot vērā blīvuma un mikrostruktūras atškirīibas mugurkaula skriemeḷa ķermeņa rajonos, var sniegt papildus ieskatu kaula lūzuma mehānismos. Piemēram, augstākās skriemeḷa gala plāksnes sabrukums ir saistīts ar mugurkaula skriemeḷu lūzumu, un šis sabrukums sākas un izplatās uz rajoniem, kas atrodas zem maza blīvuma un mehāniski zemākas mikrostruktūras trabekulārā kaula (Osterhoff et al., 2016).

Rezumējot, trabekulārā kaula strukturā pastāv lielas KMB un mikrostruktūras neviendabības ar lielu osteoporotisko lūzumu izplatību. Ir pamatoti pierādījumi tam, ka šim neviendabīgumam ir nozīmīgas biomehāniskās sekas, taču ir nepieciešami turpmāki pētījumi, lai izprastu mehānismus un pielietotu šīs atziṇas klīnikā.

Kaulaudu sastāva un biomehānisko īpašību izmaiṇas materiālā, iespējams, palielina kaulu lūzumu risku, taču vēl nesen šīs izmainas bija maz saprotamas. Vairāki pētījumi ir mēǵinājuši risināt šo problēmu, veicot gan biomehāniskos testus, gan kaulaudu sastāva analīzes audu līmenī, un atklājumi par audu īpašību un sastāva izmaiņām osteoporozes laikā ir pretrun̄̄gi. Piemēram, tika ziņots, ka trabekulārajiem kaulaudiem, kas iegūti no aitas augšstilba kaula proksimālā gala (12 mēnešus pēc ovariektomijas), bija zemāks elastības modulis, ko mēra ar lieces testu, salīdzinot ar vecumam atbilstošām kontrolgrupām. Šīs izmainas bija saistītas ar minerālvielu daudzuma samazināšanos osteoporotiskos trabekulārajos kaulaudos. Interesanti, ka atšḳirības nesaglabājās 31 mēnesi pēc ovariektomijas (Brennan et al., 2011). Turpretī kaulu 
paraugu stiepes tests parādīja, ka žurku trabekulāro kaulaudu stingums un izturība ir palielinājusies par 40-90\% 54. nedēḷā pēc ovariektomijas. Šie pieaugumi bija saistīti ar ievērojamu minerālvielu daudzuma palielināšanos (11\%) šajās trabekulās, lai gan kopējais KMB un masa bija samazināta grozītājiem (McNamara et al., 2006). Ir arī ziņojums, ka paaugstināts kalcija saturs un kaula stingums rodas arī atsevišķos cilvēka osteoporotiskā kaula trabekulās (Busse et al., 2009).

Eksperimentālās metodes, dzīvnieku modeḷa vai anatomiskās vietas izvēle, no kuras analīzei tika izvēlēts kauls, varētu izskaidrot neatbilstības starp iepriekšējiem pētījumiem. Piemēram, tika ziņots par samazinātu trabekulāro stingumu, izpētot kaulu paraugus uz lieci no augšstilba kaula anteromediālā rajona aitām pēc ovariektomijas (Brennan et al., 2011). Turpretī paaugstināts trabekulārā kaula stingums bija kaula paraugiem no apakšstilba augšanas plāksnes rajona pēc kaulu paraugu parbaudes uz stiepi žurkām pēc ovariektomijas (McNamara et al., 2006). Lieces tests raksturo kaulaudu biomehāniskās īpašības (elastîbas modulis, cietība) konkrētās kaulaudu vietās (lamellās), turpretī stiepes tests novērtē visu trabekulu biomehāniskās īpašības. Tādēl, lai izprastu šīs neatbilstības, tika mēǵināts izdalīt minerālu telpisko sadalījumu dažādās lamellās pa atsevišḳām trabekulām un trabekulārās mineralizācijas izmaiņas proksimālā augšstilba dažādos anatomiskajos reǵionos pēc estrogēna deficīta sākuma. Minerālvielu saturu (Ca masas \%) noteica, izmantojot kvantitatīvu ar atpakaḷejošu skenējošu elektronu mikroskopijas metodi individuālām trabekulām no aitu proksimālā augšstilba kaula gala (12 mēneši pēc ovariektomijas), un vecuma grupām atbilstošajām kontrolēm. Tika atklāts, ka atšḳirība mineralizācijā starp trabekulu virspusējām un dziḷajām lamelēm bija izteiktāka aitām pēc ovariektomijas, minerālvielu neviendabīguma palielinājumam par aptuveni 13\%, salīdzinot ar trabekulām no kontroles grupas. Turklāt tika pierādīts, ka kaulu minerālvielu sadalījums ir atkarīgs no anatomiskās atrašanās vietas: augšstilba kaula proksimālā galā bija lielāku mineralizācijas starpība starp lielo un mazo grozītāju aitām pēc ovariektomijas, kas sakrīt ar lūzuma līniju starp grozītājiem (Brennan et al., 2011).

Straujš kaulu resorbcijas ātruma pieaugums ar osteoklastiem notiek osteoporozes sākumā, bet laika gaitā tas mazinās. Tādējādi atškirības starp dažādiem pētījumiem varētu būt saistītas arī ar slimības progresēšanas pakāpi, kuras ilgums, iespējams, atšḳiras atkarībā no dzīvnieku modeḷa un cilvēka kaula. 2014. gadā veikta pētījuma mērḳis bija izprast, kā trabekulāro audu mineralizācija mainās ilgstošā estrogēna līmeņa samazināšanās dẹl, un salīdzināja to ar normālām ar vecumu saistîtām izmaiṇām trabekulāro kaulu audu sastāvā. Kaulu minerālā blīvuma sadalījuma parametrus salīdzināja ar trabekulām, kas iegūtas no augšstilba kaula proksimālā gala aitām pēc ovariektomijas, kuras bija pakḷautas estrogēna 
deficītam 12 vai 31 mēnesi, un trabekulām no kontroles grupas. Tika ziṇots, ka normāla novecošanās palielina mineralizāciju un minerālu neviendabīgumu trabekulārā līmen̄̄ un ka šīs atšķirības rodas tāpēc, ka novecojot palielinās trabekulu dziļo lamellu mineralizācija. Tomēr ilgstošs estrogēna deficīts (31 mēnesis) noved pie ievērojami samazinātas vidējās mineralizācijas, salīdzinot ar trabekulām no abām vecumam atbilstošām kontrolgrupām, un īsāka estrogēna deficīta ilguma (12 mēneši). Paaugstināts kaula aprites ātrums estrogēna deficīta laikā varētu izskaidrot šo zemāko vidējo mineralizāciju. Tomēr mineralizācijas samazināšanās nebija viendabīga augšstilba kaula proksimālā gala (Brennan et al., 2014). Pamatmehānismi, ar kuriem mainās trabekulārā minerālu neviendabīgums osteoporozes laikā, varētu būt saistīti ar hipermineralizētiem osteocītu lagūnam osteoporotiskā trabekulārā kaulā un palielināta kaula aprites laika. Turklāt šī mainība var būt saistīta ar vietējām biomehāniskās vides izmain̄ām, kas var izraisīt audu minerālu satura izmaiņas tajos rajonos, ko regulē mehanosensitīvas kaulu šūnas (McNamara et al., 2010). Kopā šie pētījumi atklāj ilguma un anatomiskās atrašanās vietas nozīmi, novērtējot estrogēna deficìta ietekmi uz trabekulārā kaula mineralizāciju, un var izskaidrot neatbilstības attiecībā uz estrogēna deficīta ietekmi starp iepriekšējiem pētījumiem (Brennan et al., 2014).

Osteoporozes laikā kopējā trabekulārā kaulu masa un izturība tiek samazināta, trūcīgie trabekulārie audi, kas paliek, ir neviendabīgāki, un trabekulāro audu rajoni ir vairāk mineralizēti, stīiāki un stiprāki. Varētu šķist arī tas, ka š̄is izmaiņas ir īslaicīgas un vietai raksturīgas osteoporozes pazīmes, un slimības progresēšanas laikā trabekulāro audu īpašības mainās.

\subsection{Osteoporotiskā kortikālā kaula izmainas}

Kaula biomehānisko kompetenci nosaka kaulaudu daudzums un kvalitāte, bet vēl svarīgāk ir kaulaudu izvietojums telpā. G̦eometriskie izmēri, tajā skaitā kaula lielums, šḳērsgriezuma vai inerces momenta laukums, veido līdz $80 \%$ no kaula biomehāniskās kompetences. Spieķkaula distālās epifīzes lūzuma slodzes prognozējošie faktori ir kortikālā kaula masas, laukuma un platuma mērījumi. Savukārt augšstilba kaula proksimālās epifīzes lūzuma slodzes prognozējošie faktori ir augšstilba kaula kakliṇa lielums un inerces moments (Augat et al., 1996). Atsevišķu parametru kombinācija vairākos regresijas modeḷos ir sniegusi papildus pierādījumus tam, ka ǵeometriskie mērījumi ievērojami uzlabo kaulu izturības noteikšanu, salidzinājumā ar kaulu minerālblīvuma mērījumu (Lang et al., 1997). Līdz ar to tika konstatēts, ka kaulu lūzumu risks ir saistīts ar noteiktām geometriskām pazīmēm, piemēram, ar kortikālā kaula lokālu retināšanu (Crabtree et al., 2001). 
Kortikālā kaula biomehāniskā kompetence ir ḷoti atkarīga no tā porainības. Kortikālo kaulaudu struktūras pamatelements ir osteons. Haversa kanāli orientēti kaula garenass virzienā un Folkmana kanāli izvietojas perpendikulāri, perforējot kortikālā kaula matricu. Virzienā uz iekšējo kortikālo kaulu virsmu Haversa kanāli var apvienoties un savienoties arī ar kaula smadzeņu dobumu. Haversa kanāli un resorbcijas dobumi rada porainību kaulaudos, un poru diametrs var svārstīties no dažiem līdz pat vairākiem simtiem mikrometriem. Poru skaits un lielums nosaka kortikālā kaula iekšējas virsmas porainību un kaulu minerālblīvumu. Palielinoties poru lielumam, kortikālā kaula biomehāniskās īpašības ievērojami pasliktinās. Tādējādi porainība veido aptuveni $70 \%$ no kortikālā kaula elastības moduḷa un 55\% no tecēšanas robežas sprieguma. Attiecīgi, palielinoties porainībai, ievērojami samazinās arī kaula lūzuma izturība, iespējams, pieejamas mikroplaisu izplatības platības samazināšanās dēl (Wachter et al., 2002).

Ar vecumu saistītas kaulu biomehāniskās kompetences samazināšanās ir izteiktākās biomehāniskām īpašībām, kas saistītas ar sabrukšanu, nekā tām, kas saistītas ar stingumu. Enerǵijas absorbcija, izturība pret lūzumiem un graujošā stiepes deformācija parāda ar vecumu saistītu kaulu biomehāniskas kompetences samazinājumu par 5-10\% desmitgadu laikā, bet elastības stiepes un kompresijas moduḷi samazinās tikai par 2\% desmitgadu laikā. Tādēl saistība starp kaulu sabrukšanas un stinguma īpašībām mainās, palielinoties audu nobriešanas pakāpei. Tas vēl vairāk apgrūtina precīzu kaulu lūzumu riska prognozēšanu. Kaulu lūzumu riska prognozēšana lielā mērā balstās uz neinvazīvu attēla novērtējumu un kaulu minerālblīvuma mērī̌sanu. Kaut arī kaulu minerālblīvums ir cieši saistīts ar kaulu stinguma īpašībām, tā saistība ar sabrukšanas izturību nav tik izteikta (Osterhoff et al., 2016).

Kaulu biomehāniskās kompetences izmaiņas ir izskaidrojamas ar kaulu struktūru funkcionālu adaptāciju un ar vecumu saistītu iekšējo biomehānisko īpašību pasliktināšanu, kas ir tieši saistītas ar kaula apriti. Kad kaula aprite tiek nomākta, palielinās stipri mineralizēto kaulaudu attiecība pret vāji mineralizētiem jaunveidotiem kaulaudiem, rezultātā palielinas kortikālā kaula viendabīgums. Plaisās vieglāk aug viendabīgos audos, samazinot kompozītmateriālu izturību. Turklāt biomehaniskās īpašības izmainās, ja samazinās kolagēnu šḳiedru virziens. Ir pierādīts, ka kolagēna tīkls novecošanās laikā zaudē līdz $50 \%$ spējas absorbēt enerǵiju, iespējams, procentuāla augstas denaturētā kolagēna daḷas dēḷ (Wang et al., 2001). Ar vecumu kaulaudu mineralizācijas pakāpe palielinās, rezultātā kortikālā kaula minerālvielu daudzums palielinās. Tā kā ar vecumu kortikālā kaulā uzkrājas mikrobojājumi, vienlaicīgi palielinās mikroplaisu blīvums. Pēc 50 gadu vecuma kortikālā kaulā uzkrājas mikroplaisas, savukārt sievietēm tas notiek daudz ātrāk nekā vīriešiem (Schaffler et al., 1995). 
Ne tikai kortikālo kaulu izmaiņas saistās ar vecumu, bet arī kaulu ǵeometriskie parametri pielāgojas modificētai mehāniskai videi. Būtībā palielinās kaulaudu gan ārējais, gan iekšējais diametrs, vienlaikus samazinoties kortikālā kaula biezumam (Tong et al., 2015). Turklāt porainība ar vecumu palielinās, rezultātā palielinās iekšejā kortikālā kaula virsma. Porainības palielināšanās atkarīga no Haversa kanālu saplūšanas kaulaudos un iekšējās kortikālā kaula virsmas fragmentācijas. Atlikušajām kortikālo audu paliekām ir līdzība ar trabekulāro kaulu, un tās var aprakstīt ar iekšējo kortikālā kaula virsmas trabekulāciju. Kortikālā kaula porainība palielinās no 4\% veseliem jauniem cilvēkiem līdz 12\% 60 gadu vecumā un līdz gandrīz 50\% ļoti veciem cilvēkiem. Palielinoties kortikālā kaula virsmas laukumam, tiek nodrošināta lielāka virsma signālu saņemšanai kaula apritei un, tādējādi, ar vecumu vēl vairāk paātrinās kortikālo kaulaudu zudums. Faktiski lielāka trabekulārā kaula daḷa ir trabekulizēti kortikālu kaulu fragmenti (Seeman, 2013). Agrīnā vecumā kaulu zudums dominē trabekulārām kaulam, pieaugot vecumam, galvenokārt tiek zaudēts perifēro kaulu kortikālais daḷa. $50 \%$ kaulu zudums rodas kortikālā kaula iekšējās virsmas audos, retinot kortikālo kaulu un atstājot kortikālā kaula fragmentus (Zebaze et al., 2010).

Ar vecumu saistītas kortikālā kaula adaptīvās izmaiņas lielā mērā ir atkarīgas no kaulaudu atrašanās vietas. Augšstilba kaula kakliṇa kaulaudu zudums ir viszemākais no tiem rajoniem, kuros normālas gaitas laikā ir vislielākā slodze, savukārt rajonos, kur ir mazāka slodze, trabekulārie kaulaudi tiek retināti ar kortikālā kaula iekšējās virsmas absorbcijas palīdzību. Tomēr, kā praksē rāda, šie rajoni ar samazinātu biezumu piedz̄ivo vislielāko spriedzi kritiena laikā un, visticamāk, lūzīs cilvēkiem vecumā. Augšstilba kaula ķermeņa kaulaudos par līdzīgu mehānismu ziņots jau sen. Apakšdelma kaula distālā galā ar vecumu saistītā adaptācija tiek atspoguḷota kā endosteālā absorbcija kopā ar periosteālu pieeju, palielinot inerces laukuma momentu un tādējādi zināmā mērā saglabājot kaulu stingrību un izturību (Bouxsein et al., 1994). Šì adaptīvā reakcija ir novērota abiem dzimumiem, tomēr efektīvāka vīriešiem.

Kaut arī ir atzīta kortikālā kaula izšķirošā loma kaula biomehāniskās kompetences un lūzuma riska noteikšanai, tas nav īsti izmantots klīniskajā praksē lūzumu riska novērtēšanai vai osteoporozes ārstēšanas uzraudzībai. Turpmākās klīniskās attēlveidošanas metodēs būs jāṇem vērā kortikālā kaula g̊eometriskās pazīmes kā arī kaulu lokālu porainību (Osterhoff et al., 2016).

\subsection{Osteoporozes medikamentozās terapijas ietekme uz kaulaudu kvalitāte}

Osteoporozes farmakoterapijas mērķis ir, galvenokārt, samazināt kaulu masas zudumu un līdz ar to lūzumu risku. Osteoporozes ārstēšanai plaši tiek izmantoti farmakologiskie līdzekḷi kā, piemēram, bisfosfonāti, denosumabs, raloksifēns un parathormona peptīdi (Reid, 2015; Shin et al., 2020). 


\section{Kalcijs un D vitamīns}

Līdztekus osteoporozes ārstēšanai ļoti būtiski ir nodrošināt organismu ar pietiekamu kalcija un D vitamīna daudzumu uzturā, taču tikai ar to nepietiek, lai samazinātu kaulu lūzumu risku. Ieteikumi par D vitamīna uzṇemšanu uzturā balstās uz kalcija un D vitamīna kombinācijas ieguvumiem skeleta veselībai; nav pierādījumu, kas apstiprinātu tikai D vitamīna uzṇemšanas ieguvumus, lai gan dati ir pierādījuši to lietderību glikokortikoīdu izraisītas osteoporozes profilaksē un ārstēšanā (Hiligsmann et al., 2017).

Kalcijs ir būtiska jebkura organisma uztura sastāvdaḷa, kas nodrošina maksimālas kaulu masas sasniegšanu jaun̄̄bā. Kad netiek nodrošināts pietiekams kalcija līmeņa daudzums serumā, pastiprinās kaulu resorbcija. Parasti sievietēm pēcmenopauzes periodā osteoporozes gadījumā ieteicamā kalcija deva ir 1200 mg (kopējais patēriņš ar uzturu un preparātu veidā), (Pavone et al., 2017). Kalcija daudzums, kas pārsniedz 1200 - 1500 mg dienā nedod papildieguvumu kaulu veselībai, bet var izraisīt nierakmeņu veidošanos un sekmēt kardiovaskulārās slimības (Lejnieks, 2012).

D vitamīns veicina kalcija uzsūkšanos kuṇgáa-zarnu traktā. Sievietēm pēcmenopauzes periodā ieteicama D vitamīna deva ir 800 starptautiskās vienības, kas ir jāṇēm vērā pirms jebkādas osteoporozes farmakologiiskās ārstēšanas uzsākšanas (Pavone et al., 2017). D vitamīna nepietiekamības risks ir daudziem gados veciem pacientiem ar malabsorciju (piem., celiakiju), hronisku nieru slimību, lielu ķermeņa masas indeksu, glikokortikoīdu vai antikonvulsantu terapiju un cilvēkiem, kas maz uzturas saulē. Šiem cilvēkiem bieži D vitamīna deva var sasniegt 2000 starptautiskās vienības vai pat vairāk - vēlama 25(OH)D līmeṇa augšējā norma serumā ir $60 \mathrm{ng} / \mathrm{ml}$ (Lejnieks, 2012).

\section{Bisfosfonāti}

Bisfosfonātu grupas preparāti ir neorganiskā pirofosfăta analogi, kuri spēcīgi saistās ar kaulaudu kalcija hidroksiapatīta kristāliem un paliek kaulu virsmas tuvumā vairākus mēnešus vai gadus. Bisfosfonāti nomāc osteoklastu darbību, samazinot kaulu resorbciju. Perorālo bisfosfonātu efektivitāti osteoporozes ārstēšanai apstiprina vairāki pētījumi. Šo iemeslu dēḷ, ja nav konkrētu kontrindikāciju, perorālie bisfosfonāti tiek uzskatīti par pirmās kārtas farmakoloǵisko terapiju lielākajai daḷai sieviešu pēc menopauzes, kurām ir augsts kaulu lūzumu risks (Pazianas et al., 2016). Ar īpašiem intracelulāriem ceḷiem bifosfonāti iedarbojas uz osteoklastiem, izraisot šūnu toksicitāti. Bifosfonāti saistās ar hidroksiapatītu, tādējādi, tiek absorbēti kaulos, kavējot osteoklastisko kaulu resorbciju. Tas notiek ar vairākiem veidiem: nobriedušu osteoklastu citotoksisks vai metabolisks ievainojums, osteoklastu piestiprināšanās 
kavēšana kaulaudiem, osteoklastu izdalīšanās vai veidošanās kavēšana, kā arī iejaukšanās osteoklastu struktūru īpašībās, nepieciešamas kaulu resorbcijai (Nayak et al., 2016).

Ir divas bisfosfonātu apakšklases: visbiežāk sastopamie slāpekli saturošie (piem., alendronāts, ibandronāts, pamidronāts, risedronāts un zoledronāts), un slāpekli nesaturoši bisfosfonāti (piem., etidronāts). Slāpekli saturošie bisfosfonāti inhibē mevalonāta ceḷu - būtisku metabolisma ceḷu, kas iesaistīts osteoklastu veidošanā un funkcionēšanā; slāpekli nesaturošie bisfosfonāti darbojas, veidojot metabolītus, kas veido toksiskus ATF analogus, inducējot osteoklastu apoptozi (Garg et al., 2013). Pirms bisfosfonātu terapijas uzsākšanas ir svarīgi ārstēt blakusslimības, piemēram, hipokalēmiju, D vitamīna deficītu un nieru darbības traucējumus, kas var noteikt, attiecīgi izmērot kalcija, 25(OH) D līmeni serumā un kreatinīnu (Pavone et al., 2017).

Pirmā bifosfonātu terapijas izvēle ir alendronāts vai risedronāts perorāli, ko lieto vismaz ar $240 \mathrm{ml}$ ūdens vienu reizi nedẹl̦ā tukšā dūšā no rīta. Pēc medikamentu perorālas ievadīšanas pacientam jāstāv stāvus vismaz 30-60 minūtes un vismaz 30 minūtes jāatturas no pārtikas, dzērienu vai medikamentu lietošanas. Tādā veidā tiek samazinātas iespējamās kuṇgáa-zarnu trakta blakusparādības (Nayak et al., 2016). Parasta perorāla alendronāta deva osteoporozes $70 \mathrm{mg}$ vienreiz nedẹlā (kopā ar vitamīnu D) un $5 \mathrm{mg}$ dienā (vai $35 \mathrm{mg}$ vienreiz nedēḷā) osteoporozes profilaksei. Pacientiem, kuriem perorāla bisfosfonātu lietošana ir kontrindicēta, piemēram, pacientiem ar kuṇǵa-zarnu trakta slimībām, intravenozi jāievada zoledronskābe (intravenozas infūzijas veidā vismaz 15 minūtes gadā) vai ibandronāts (ik pēc 3 mēnešiem kā 15-30 sekunžu intravenozas injekcijas veidā). Bifosfonātu lietošanu nedrīkst pārtraukt pacientiem ar osteopātisko kaulu lūzumu, kuri š̄is zāles ir saṇēmuši mazāk nekā 5 gadus, jo iespējama aizkavēta kaulu dz̄īšana (Pavone et al., 2017).

Visizplatītākās blakusparādības, īpaši perorāli lietojamiem bisfosfonātiem, ir kungga un zarnu trakta traucējumi, piemēram, dispepsija, ezofagīts. Retos gadījumos var rasties priekškambaru mirdzēšana un nieru mazspēja. Tāpēc bifosfonātus nedrīkst lietot pacienti ar hronisku nieru slimību un glomerulārās filtrācijas ātrumu $<30-35 \mathrm{ml} / \mathrm{min}$. Turklāt netipiski augšstilba kaula lūzumi, piemēram, subtrohanteriski un kaula diafīzes daḷā, ir saistīti ar ilgstošu bisfosfonātu lietošanu, iespējams, pārmērīgas kaula aprites cikla nomākšanas dēḷ (Pazianas et al., 2016). Reti pacientiem, kas saṇem bisfosfonātu grupas preparātus, īpaši slāpekli saturošos, novēro žokḷa kaula osteonekrozi - perorālu komplikāciju, kas varētu rasties pacientiem pēc zobu ekstrakcijas vai citās invazīvas procedūras mutē. Bisfosfonātu preparātu grupas izraisītas osteonekrozes riska grupa ir pacienti ar nomāktu imunitāti un sliktu mutes dobuma higiēnu (Garg et al., 2013). Visi bisfosfonātu grupas preparāti ir kontindicēti pacientiem ar 
hipokalciēmiju, pastiprinātu jūtību pret preparātu un sievietēm grūtniecības un bērnu zīdīšanas laikā (Lejnieks, 2012).

\section{Denosumabs}

Denosumabs ir pirmā pilnībā humanizēta monoklonālā antiviela, kas saistās ar cilvēka RANKL, lai kavētu osteoklastu veidošanos un aktivizēšanu, tādējādi kavējot kaulu resorbciju. Šī kavēšana var apturēt kaulu eroziju un zudumu (Takeuchi et al., 2016). Denosumabs tika apstiprināts kā līdzeklis osteoporozes ārstēšanai sievietēm pēcmenopauzes periodā, jo tam piemīt spēcīga spēja samazināt mugurkaula un gūžas kaula lūzumus. Denosumabu lieto reizi 6 mēnešos, un tas nomāc kaulu resorbciju par 80-90\% (Suzuki et al., 2017). Denosumabu neizmanto kā pirmās kārtas farmakoloǵisko līdzekli osteoporozes ārstēšanai, bet to var izmantot kā pirmās kārtas osteoporozes ārstēšanas līdzekli pacientiem, kuri nepanes perorālos bisfosfonātus vai kuriem ir nieru mazspēja, nopietnas kontrindikācijas bisfosfonātu terapijai, kas var izraisīt toksicitāte zāḷu nieru klīrensa trūkuma dēḷ. Denosumabs sāk darboties tikai vienu mēnesi pēc terapijas uzsākšanas, un tā antiresorbcijas efekts ilgst tikai 4-6 mēnešus, tādējādi nodrošinot drošības robežu attiecībā uz pilnīgu kaula aprites cikla nomākumu. Līdzīgi kā bisfosfonātiem, pirms ārstēšanas ar denosumabu un tās laikā jāārstē D vitamīna deficīts (Pazianas et al., 2016). Klīniskajos pētījumos denosumabs bija labi panesams un neizraisīja žokḷa osteonekrozi, arteriālo fibrilāciju vai simptomātisku hipokalciēmiju (Pavone et al., 2017).

Denosumabs jālieto ḷoti piesārdzīgi. Tas nav ieteicams sievietēm pirmsmenopauzes periodā un bērniem vai kā osteoporozes profilaktiska terapija. Tā kā denosumabs kavē RANKL saistīšanos ar RANK, kas papildus preosteoklastiem tiek ekspresēts uz T-limfocītiem, B-limfocītiem un dendrītiskām šūnām, vairākos pētījumos kā denosumaba nelabvēlīgs efekts ir paaugstināts infekcijas risks. Īpaši bieži ir ziṇots par biežākām urīnceḷu infekcijām pirmā gada pacientiem pēc nieru transplantācijas. Tādēḷ pacientiem jāziṇo par visām infekcijas pazīmēm, lai veiktu atbilstošu ārstēšanu, profilaktiski var nozīmēt antibakteriālu terapiju (Bonani et al., 2017).

\section{Stroncija ranelāts}

Stroncija ranelāts ir Eiropā apstiprināts kaulu antiresorbcijas līdzeklis vīriešiem un sievietēm pēcmenopauzes vecumā ar smagu osteoporozi ārstēšanai, kuras nepanes citus farmakologískos līdzekḷus. Stroncija ranelāts sastāv no diviem stroncija atomiem, kas ir saistīti ar ranelīnskābi. Tas darbības mehānisms nav piln̄̄gi skaidrs, taču ir atzīmēts pietiekošs antiresorbcijas efekts, kā rezultātā no osteoklastu funkcijas kavēšanas un osteoblastu diferenciācijas un proliferācijas veicināšanas caur kalcija sensoru receptoru. Stroncija ranelāta darbības rezultātā palielinās KMB, kaut arī tas nav stingri saistîts ar lielu kaulu lūzumu riska 
samazinājumu (Italian Society of Osteoporosis, Mineral Metabolism and Skeletal Diseases (SIOMMMS) et al., 2013). Biežas blakusparādības ir kardiovaskulārās sistēmas traucējumi, vēnu trombembolija, miokarda infarkts, diskomforts kungǵa-zarnu traktā un nervu sistēmas traucējumu pazīmes un simptomi, piemēram, galvassāpes, krampji un atmiṇas zudumi. Retāk ir alergiskas reakcijas, piemēram, izsitumi ar eozinofîliju un sistēmiskiem simptomiem (DRESS sindroms) (Kanis et al., 2011; Das et al., 2013; Komm et al., 2015). Tā kā ir augsts sirds bojājumu risks, stroncija ranelātu mūsdienās uzskata par otrās rindas osteoporozes ārstēšanas līdzekli, to lieto tikai tad, ja citi osteoporozes medikamenti nav piemēroti ( $O$ 'Donnell et al., 2006; Horak et al., 2017).

\section{Estrogēna aizvietotājs un selektīvi estrogēnreceptoru modulatori}

Tā kā estrogēna receptora $\alpha$ un estrogēna receptora $\beta$ loma ir osteoklastu apoptozē, estrogēna aizstājterapijas vai estrogēna un progestīna (hormonu) aizstājterapijas lietošana ar tibolonu ir efektīva osteoporozes profilaksei sievietēm pēcmenopauzes periodā. Daudzi pētījumi parāda mugurkaula jostas daḷas, gūžas un augšstilba kakliņa KMB izmaiņas - ārstēšana ar hormonu aizstājterapiju palielina KMB mugurkaula jostas dạ̣ā un samazina kaula aprites cikla marķierus 2 gadu ārstēšanas laikā (Cartwright et al., 2016). Tā kā iespējams paaugstināts venozas trombemembolijas, krūts vēža, sirdsdarbības traucējuma, insulta un endometrija vēža risks, estrogēna aizstājterapija nav pirmā izvēle osteoporozes profilaktiskā ārstēšanā, un, kad ārstēšana ir uzsākta, hormoni jāievada zemākā devā uz īsu laika periodu (Tabatabaei-Malazy et al., 2017). Pētījumos ir ziṇots, ka daudzām sievietēm, kuras pēkšṇi pārtrauca hormonu aizstājterapiju, bija lielāks osteoporotisko kaulu lūzumu risks (Lobo et al., 2016).

Selektīvie estrogēnreceptoru modulatori ir ar līdzīgu iedarbību uz kaulu un sirds un asinsvadu sistēmu kā estrogēni, bet bez blakusparādībām krūts dziedzeros un endometrijā. Biežāk izmantotie selektīvie estrogēna receptoru modulatori osteoporozes profilaksei sievietēm pēcmenopauzes periodā ir raloksifēns, lasofoksifēns un bazedoksifēns, nesen Pārtikas un zāḷu pārvaldes apstiprinātas zāles. Šīs zāles ir atḷauts kombinēt ar konjugētiem estrogēniem, bet nav atrasts neviens randomizēts kontrolēts pētījums par šādas kombinācijas efektivitāti (Qaseem et al., 2017). Selektīvie estrogēna receptoru modulatori samazina mugurkaula lūzumus osteoporotiskām sievietēm, palielinot trabekulārā kaula masu aksiālajā skeletā, taču nav statistiski nozīmīgu datu, kas pierādītu, ka tie samazina risku, kas saistīts ar mugurkaula vai gūžas kaula lūzumiem, salīdzinot ar placebo. Turklāt tika pierādīts, ka raloksifēns palielina kortikālā kaula porainību (Börjesson et al., 2016). Selektīvie estrogēna receptoru modulatori ir efektīvi krūts vēža profilaksē un ārstēšanā sievietēm pirmsmenopauzes periodā, bet palielina insulta, trombembolijas, kāju krampju un vazomotorisko simptomu biežumu sievietēm 
pēcmenopauzes periodā. Š̀̄ iemesla dēḷ tie ir kontrindicēti osteoporozes profilaksei vai ārstēšanai sievietēm pirmsmenopauzes periodā, taču tās tiek ieteiktas kā pirmās līnijas terapija osteoporozes profilaksei sievietēm pēcmenopauzes periodā (Tabatabaei-Malazy et al., 2017).

\section{Kalcitonīns}

Kalcitonīns kavē kaulu resorbciju, palielinot osteoblastu aktivitāti. Vēl nesen kalcitonīns tika uzskatīts par otrās kārtas osteoporozes ārstēšanas līdzekli, kad pirmās kārtas zāles ir nepanesamas vai neizraisīja terapeitisko efektu. Kā liecina pētījumi, līdz šim dati par kalcitonīna ietekmi uz KMB ir neskaidri. Kalcitonīns ir pieejams injekciju veidā un intranazāli; ir arī izstrādātas perorālās zāḷ formas, kas ir ērtākas nekā cita ievadīšanas veida zāḷu formas (Bandeira et al., 2016). Sievietēm, kuras ārstētas ar kalcitonīnu, palielinās mugurkaula jostas daļas KMB un samazinās kaula aprites cikla biomarḳieri, īpaši sievietēm, kuras lieto perorālo zāḷu formu; tomēr kalcitonīns neaizkavē jaunu skriemeḷu, mugurkaula vai gūžas lūzumu rašanos. Nesen veiktā lielā klīniskā pētījumā neizdevās pierādīt, ka kalcitonīns ir efektīvs līdzeklis osteoporotisku kaulu lūzumu novēršanai (Henriksen et al., 2016).

\section{Teriparatīds}

Teriparatīds ir rekombinantais cilvēka parathormona peptīds. Tas ir pirmais un pašlaik vien̄̄gais apstiprinātais anaboliskais līdzeklis osteoporozes ārstēšanai, kas stimulē osteoblastisku kaulu veidošanos, lai uzlabotu kaulu kvalitāti un kaulu masu. Šis efekts visvairāk izteikts trabekulārajos kaulos. (Lindsay et al., 2016). Tas aktivizē osteoblastus, saistoties ar 1. tipa PTH/PTHrP receptoriem, tieši stimulējot kaulu veidošanos uz aktīvajām un iepriekš neaktīvajam kaulu remodelēšanas vietām, ierosinot jaunas kaulu remodelēšanas vietas. Vairāki pētījumi ir parādījuši strauju kaulu veidošanās bioḳīmisko marḳieru pieaugumu pirmajos teriparatīida terapijas mēnešos bez tam sekojošas kaulu resorbcijas palielināšanās. Tāpēc ir saprotams, ka ārstēšanas sākumposmā kaulu veidošanās pārsniedz kaulu resorbciju. Teriparatīds izraisa KMB palielināšanos, kas skaidri novērojams ar osteodensitometriju. Pēc 24 ārstēšanas mēnešiem (kopējais ārstēšanas laiks pacientiem ar osteoporozi un paaugstinātu kaulu lūzumu risku) KMB palielinas mugurkaula jostas dạ̣ā un augšstilba kakliṇā, samazinot kaulu lūzumu risku (Pavone et al., 2017).

\subsection{Kaulaudu aizvietošanas biomateriāli}

Materiālus, ko izmanto kaulaudu pieaudzēšanā iedala četrās grupās (De Grado et al., 2018):

1) autogēnie kaulu transplantāti; 
2) allogēnie kaulu transplantāti, kas ņemti no cilvēku līķiem;

3) ksenogēnie kaulu transplantāti, kas sagatavoti no dzīvnieku kauliem;

4) mākslīgi radīti no dabiskas vai sintētiskas izcelsmes izejvielām kaulaudus aizvietojošie biomateriāli.

Gada laikā vairāk nekā 2 miljonu kaulaudu augmentācijas tiek veiktas pasaulē, plaši izmantojot autogēno kaulu, kas tiek kvalificēts kā "zelta standarta" kaulu aizvietojošais biomateriāls (Campana et al., 2014). Kaulu defektu aizpildīšanai tiek izmantoti daudz dažādu biomateriālu. Tie var būt allogēnie kauli, ksenogēnie kauli vai sintētiski kaulu aizvietotāji, kuri var tikt izmantoti defektīvu kaulu atjaunošanai autogēno vai allogēno kaulu vietā. Ideāls kaulaudu aizvietotājs atbilst noteiktām īpašībām, piemēram, tam jābūt biosaderīgam, bioresorbējamam, osteokonduktīvam, osteoinduktīvam, pēc struktūras līdzīgam kauliem, porainam, mehāniski izturīgam, viegli lietojamam, drošam un samērā lētam. Lielākais biomateriālu daudzums ir ar osteokonduktīvām īpašībām, ḷoti mazam biomateriālu daudzumam piemīt osteoinduktīvās īpašības. Vienīgais biomateriāls, kas atbilsts ideāla biomateriāla īpašībām, ir autogēnie kaulu transplantāti. Pirmkārt, autogēnie kaulu transplantāti atbilst kaula mehāniskām un biologiiskām prasībām. Otrkārt, to lietošana ḷauj izvairīties no jebkādas imunogenitātes vai atgrūšanas problēmām un slimības pārnešanas riska. Neskatoties uz to, autogēniem kaula transplantātiem ir arī daudz trūkumu, un vissvarīgākais no tiem noteikti ir saistīts ar otrās ķirurğiskās vietas klātbūtni: donora vietu (Tilkeridis et al., 2014). Tas var izraisīt komplikācijas: hroniskas sāpes 2,5\% - 8\% gadījumos, disestēzija 6\% gadījumos un infekcija 2\% gadījumos. Dažām ķirurğiskām procedūrām, kas neprasa vispārēju anestēziju, nepieciešamība iegūt autogēno kaulu transplantātu padara šo anestēziju par obligātu, palielinot ķirurǵiskas komplikācijas risku pacientam (Offner et al., 2017).

Autogēna kaula transplantāta alternatīva ir allogēna kaula transplantāta izmantošana, taču pastāv slimības pārnešanas risks. Lai arī ir dokumentēti ḷoti reti gadījumi saistībā ar HIV pārnešanu (kopš 1989. gada ziņots par diviem gadījumiem, un tiek pieņemts, ka saslimšanas risks ir 1/1,6 miljoni) vai B un C hepatīta vīrusu pārnešanu (kopš 1989. gada ir ziņots par vienu un diviem gadījumiem, attiecīgi), nav jāizslēdz 28 cita veida vīrusu pārnešanu (Delloye et al., 2014). Turklāt jāapsver šādu biomateriālu augstās izmaksas. Vēl viena alternatīva autogēnam kaula transplantātam varētu būt ksenogēna kaula izmantošana, tomēr ir tādi paši ierobežojumi, kas ir saistīti ar imunogenitātes problēmu un slimības pārnešanas risku (Saikia et al., 2008). Galvenokārt tas attiecas uz cūku endogēno retrovīrusu un liellopu sūkḷveida encefalopātiju (Offner et al., 2017). Tādējādi, lai izvairītos no visiem šiem ierobežojumiem, sintētisko kaulu aizvietotāju lietošana kḷūst aizvien populārāka (Evaniew et al., 2013). 


\section{Hidroksiapatīts}

Hidroksiapatīts (HAP) pieder pie apatītu grupas, kas ir kristāliski savienojumi ar kristālisku sešstūrainu režği. HAP ir formula $\left(\mathrm{Ca}_{10}\left(\mathrm{PO}_{4}\right)_{6}(\mathrm{OH})_{2}\right)$, un tā ir zobu un kaulu galvenā minerālvielu sastāvdaḷa (Campana et al., 2014). Tādējādi HAP ir l̦oti bioloǵiski saderīgs materiāls, kas organismā neveicina iekaisuma reakciju. Dabīgais HAP ir ar osteokonduktīvām īpašīiām un dažādu porainību. Piemēram, trabekulārā kaula HAP ir 65\% porainība un poras diametrs no 100 līdz $200 \mu \mathrm{m}$. HAP resorbcija ir ḷoti lēna, un biomateriāls parasti tiek saglabāts vismaz 3 gadus pēc implantācijas, l̦aujot lēnām veidoties kaulam un palielināties šūnu kolonizācijai. HAP piedāvā ḷoti labas mehāniskās īpašỉbas ar kompresijas pretestību līdz 160 $\mathrm{MPa}$, tomēr to visbiežāk izmanto nelielu kaulu defektu gadījumā ar zemu slodzes līmeni (Koshino et al., 2001). HAP ir gan dabiskā, gan sintētiskā formā un divfāžu HAP/TCP biokeramikai parasti dod priekšroku, salīdzinot ar tikai HAP izmantošanu. Pastāv arī dažādi laboratorijas apstākḷ̆os sintezēti kompozītmateriāli, kas satur HAP un kolagēnu. Dzīvā organisma kaulus galvenokārt veido kolagēns un Ca hidroksiapatīta kristāli. Tādējādi divkomponentu biomateriāli, kas satur HAP un kolagēnu, ir ar labākām osteokonduktīvām īpašībam, nekā vienkomponenta biometariāli. Ir pierādīts, ka gan HAP, gan I tipa kolagēns veicina osteoblastu diferenciāciju, bet apvienojot tos kopā, tika paātrināta osteoǵenēzi. Ar kolagēnu saistītiem HAP kompozītiem ir dažas mehāniskas priekšrocības salīdzinājumā ar HAP biomateriālu, ko lieto atsevišḳi. Kolagēna pakḷautība deformācijai ḷauj palielināt hidroksilapatîta slikto izturību pret lūzumu (Campana et al., 2014).

HAP un kolagēna kompozīti var kalpot kā medikamentu piegādes sistēma HAP porainības dēḷ, l̦aujot absorbēt uz savās virsmās lielu olbaltumvielu un citu molekulu daudzumu, piem., antibiotikas.

\section{Kalcija sulfāts}

Par pirmajiem terapeitiskajiem panākumiem, lietojot kalcija sulfātu $\left(\mathrm{CaSO}_{4}\right)$ kā kaulu aizstājēju, ziṇots jau 1892. gadā. Kalcija sulfātu sauc par "gípsi” vai "Parīzes apmetumu”, un tikai 1996. gadā ASV FDA apstiprināja kalcija sulfăta lietošanu implantācijai medicīnas nolūkos (Campana et al., 2014). Kalcija sulfătam ir daudz priekšrocību, jo tā struktūra ir līdzīga kaulam. Biomateriāls ir osteokonduktīvs, lēts, neizraisa alergiskas reakcijas un pieejams dažādās formās (cietās granulas un injicējamie šķidrumi). Turklāt kalcija sulfātam ir kristāliska osteokonduktīva struktūra, kur var ieaugt kaulaudu kapilāri un perivaskulārie mezenhimālie audi. 1-3 mēnešu laikā kalcija sulfāts pilnīgi resorbējas (Roberts et al., 2012). Šī resorbcija rada porainību, vienlaikus stimulējot asinsvadu ieaugšanu augmentātā un jaunu kaulaudu veidošanu. Tomēr kalcija sulfāta resorbcijas ātrums ir lielāks par jaunu kaulu veidošanu, tādēḷ kalcija 
sulfāts nav piemērots kā materiāls agrīnai funkcionālai rehabilitācijai (Podaropoulos et al., 2009). Kalcija sulfātu var izmantot vietējai antibiotiḳu vai augšanas faktoru piegādei (Ferguson et al., 2014). Lai arī kalcija sulfătam ir daudz priekšrocību, papildus ātrai resorbcijai ir arī daudz trūkumi. Kalcija sulfătam nav osteoinduktīvas un osteogēnas īpašības, un daudzos gadījumos brūces apsārtums un pietūkums pēc ķirurğiskām procedūrām var saglabāties ilgu laiku. Šāda veida komplikācijas parasti jāārstē ar vietējo brūču aprūpi, bet dažreiz ir nepieciešama turpmākās ķirurǵiskās iejaukšanās (Liodaki et al., 2016).

\section{Kalcija fosfāta cements}

1986. gadā tika izgudrots kalcija fosfāta cements, un 1996. gadā ASV FDA apstiprināja tetrakalcija fosfātu un dikalcija fosfāta dihidrātu slodzi nenesošo defektīvu kaulu ārstēšanai (Campana et al., 2014). Šis bioloǵiski absorbējamais materiāls var palikt organismā līdz 2 gadiem bez resorbcijas, atkarībā no tā sastāva. Tas sastāv no kalcija fosfāta pulvera, kas sajaukts ar šķidrumu, lai veidotu funkcionējošu pastu. Tā izotermiskā sacietēšanas reakcija mainās no 15 līdz 80 minūtēm atkarībā no zāḷu formas, rezultātā veidojas nanokristālisks HAP, kas padara kalcija fosfāta cementu osteokonduktīvu (Burguera et al., 2006). Galvenā kacija fosfāta cementa pastas priekšrocība ir iespēja pieldīt sarežǵītās formas kaula defektus. Turklāt daži kalcija fosfāta cementi ir injicējami, un tos var izmantot minimāli invazīvās procedūrās, piemēram, vertebroplastikā. Tāpat kā citi kaulu aizvietotāji (piemēram, kalcija sulfăts un daži uz HAP bāzes balstīti kaulu aizvietotāji), kacija fosfāta cements ir trausls un var izraisīt dažas komplikācijas. Klīniskie rezultāti nav labāki un dažreiz sliktāki par metilmetakrilāta vai autogēna kaula lietošanu, kalcija fosfāta cements jāizmanto selektīvi (Afifi et al., 2010).

\section{Trikalcija fosfāts}

Trikalcija fosfāts (TCP; $\left.\mathrm{Ca}_{3}\left(\mathrm{PO}_{4}\right)_{2}\right)$ kopā ar HAP ir viens no visvairāk pētītiem kalcija fosfătiem. Kalcija fosfăts ar $\mathrm{Ca} / \mathrm{P}$ attiecību 1,5 un ir sadalīts $\alpha$ fāzē un $\beta$ fāzē. $\alpha$-TCP ir monokliniskas telpas grupas kristāla struktūra un $\beta$-TCP ir romboedriskās kosmosa grupas kristāla struktūra. $\alpha$-TCP var veidoties $1125^{\circ} \mathrm{C}$ vai augstākā temperatūrā, un $\beta$-TCP veidojas 900-1100 ${ }^{\circ} \mathrm{C}$ temperatūrā. $\beta$-TCP ir stabilāka struktūra un augstāka bioloǵiskās noārdīšanās pakāpe nekā $\alpha$-TCP, tāpēc $\beta$-TCP parasti izmanto kaulu reǵenerācijā (Horch et al., 2006).

$\beta$-trikalcija fosfātu ( $\beta$-TCP) vairāk nekā 25 gadus galvenokārt izmanto kā kaulu aizvietotāju, galvenokārt ortopēdijas un zobārstniecības praksēe, un to uzskata par sintētiskā kaula “zelta standartu” (Galois et al., 2002). Tas ir bioloǵiski saderīgs un bioloǵiski absorbējams materiāls ar īpašībām, kas līdzịgas kaula neorganiskai fāzei. $\beta$-TCP ir osteokonduktīvs tā sastāva un porainības dēl, kas ir atkarīgs no apstrādes apstākḷiem. $\beta$-TCP pakāpeniski resorbējas, un, kaut arī tā resorbcija nav prognozējama un ir lēnāka nekā kalcija 
sulfāta resorbcija, ir paredzēts, ka osteoklasti laicīgi piln̄̄bā resorbē $\beta$-TCP. $\beta$-TCP resorbējas apmēram 13-20 nedẹḷu laikā pēc implantācijas un pēc tam tiek pilnībā aizstāts ar remodelēto kaulu (Bohner, 2000). Turklāt $\beta$-TCP ar savstarpēji savienotām porām var paātrināt kaula apriti, atvieglojot osteogēno šūnu kolonizāciju, kas varētu ietekmēt uz angioǵenēzi. In vivo pētījumi parādīja jauveidoto kaulu no 45\% (pērtiķu mugurkaula ķermeņos) līdz 70\% (sivēnu apakšžokḷos) 6 mēneši pēc implantācijas, un 95\% pēc 2 gadiem (De Grado et al., 2018). $\beta$ TCP lietošana parādīja ḷoti maz komplikāciju, piemēram, infekciju vai nesavienotību. Tomēr mehāniskā izturība ir zemāka, salidzinot ar trabekulāra vai allogēna kaula aizvietotāja mehāniskām īpašībām (Gouin et al., 2010).

\section{Divfāžu kalcija fosfāta biokeramika (HAP/ß-TCP biokeramika)}

$\beta$-TCP lielākoties izmanto kopā ar HAP. Sintētisko HAP izgatavo, izgulsnējot kalcija nitrātu un amonija dihidrogēnfosfātu. Š̄̄ saistība sniedz visas šo divu komponentu priekšrocības: osteokonduktivitāti, bioloǵisko savietojamību, drošu un neallergēnu lietošanu un kaulu veidošanās veicināšanu (Campana et al., 2014). Divfāžu biokeramikas (HAP un $\beta$-TCP maisījuma) lietošanas lielākais ieguvums ir to resorbcijas īpašībās. $\beta$-TCP resorbcija ir ātrāka nekā HAP resorbcija, savukārt HAP mehāniskās īpašības ir nedaudz labākas nekā $\beta$-TCP (vidējā kompresijas pretestība attiecīgi ir 160 un $100 \mathrm{MPa}$ ). Tādējādi $\beta$-TCP un HAP biomateriālu kombinācija nodrošina ātrāku un augstāku kauluaudu ieaugšanas ātrumu nekā tikai lietojot HAP, vienlaikus piedāvājot labākas mehāniskās īpašības nekā tikai lietojot $\beta$-TCP (Saikia et al., 2008). 12 mēnešus pēc materiāla implantācijas 60\% $\beta$-TCP resorbējas salīdzinot ar tikai $10 \%$ no HAP. HAP un $\beta$-TCP biokeramikas veido spēcīgu tiešu saikni ar saimnieka kaulu. Neskatoties uz $\beta$-TCP mehānisko īpašību uzlabošanos, HAP un $\beta$-TCP biokeramikas mehāniska izturība joprojām ir zemāka par kortikāla kaulu kompresijas izturību, kas ir no 150 līdz $200 \mathrm{MPa}$ (De Grado et al., 2018). Atkarībā no HAP/ $\beta$-TCP attiecībam starp šiem diviem komponentiem, ir iespējams koreǵēt absorbcijas ātrumu un pakāpi, kā arī mainīt biokeramikas mehānisku spēku (Boden et al., 1999).

\section{Bioaktīvais stikls}

20. gadsimtā tika izgudrots bioaktīvs stikls (biostikls) - silikāti, kas ir savienoti ar citiem organismā atrodamiem minerāliem (Ca, $\mathrm{Na}_{2} \mathrm{O}, \mathrm{H}$ un P). Sākotnējais biostikla sastāvs ir 45\% silīcija dioksīds $\left(\mathrm{SiO}_{2}\right), 24,5 \%$ kalcija oksīds $(\mathrm{CaO}), 24,5 \%$ nātrija oksīds $\left(\mathrm{Na}_{2} \mathrm{O}\right)$ un $6 \%$ fosfora pentoksīds $\left(\mathrm{P}_{2} \mathrm{O}_{5}\right)$, (Hench et al., 1984). Ja biostiklu iemērc ūdens šḳīdumā vai ķermeņa šķidrumā, tā virsma pārvēršas par silīcija dioksīdu $\left(\mathrm{CaO} / \mathrm{P}_{2} \mathrm{O}_{5}\right)$ - bagātu gēla slāni, kas pēc dažām stundām mineralizējas, izveidojot hidroksikarbonātu. Biostikls ir bioloǵiski saderīgs, osteokonduktīvs un atkarībā no tā apstrādes stāvokḷa tam piemīt poraina struktūra, kas veicina 
biostikla resorbciju un kauluaudu ieaugšanu (De Aza et al., 2003). Biostikla lietošana neizraisa iekaisuma reakciju, un uz silīcija dioksīda bāzes biostikls resorbējās pēc 6 mēnešiem (Campana et al., 2014). Nesen ir izstrādāts fosfātu vai borātu saturošs biostikls. Borātu saturošs biostikls ir viegli izgatavojams, uzrāda ātrāku noārdīšanos nekā biostikls, kuru pamatā ir silīcija dioksīds, bet šo noārdīšanās ātrumu var kontrolēt, mainot tā sastāvu. Šī spēja noved pie iespējamās sakritības ar kaulu reǵenerācijas ātrumu (Rahaman et al., 2011). Uz fosfāta bāzes biostikls nodrošina kontrolējamu šķīdību, manipulējot ar to sastāvu (Knowles et al., 2003). Kad implantē kaulaudos, šiem biomateriāliem ir cieša saikne ar kaulaudiem. Tomēr biostikls ir diezgan trausls un tām ir zema mehāniskā izturība un samazināta izturība pret lūzumiem (Campana et al., 2014).

\section{Kaulu aizvietošanas biomateriāli uz polimēra bāzes}

Sintētiski polimēri var būt nešḳistoši (piemēram, polimetilmetakrilāts (PMMA)) vai pilnībā bioloğiski šḳīstoši, tādējādi nodrošinot laicīgu pilnīgu kaula apriti (piemēram, polilaktīnskābe (PLS)), nepaliekot svešķermenim (Campana et al., 2014). Imitējot kolagēno matricu, tiek sintizēti poliesteri, piemēram, ( $\varepsilon$-polikaprolaktons (PKL)) - tiem piemīt struktūrāla porainība un osteokonduktīvās īpašības (Wagner et al., 2016). Lielākā daḷa no uz polimēru bāzes izgatavotajiem kaulu aizstājējiem ir piemēroti izmantošanai kā bioaktīvās molekulas vai augšanas faktoru nesēji, kas potenciāli piešķir osteoǵenētiskās īpašības (Ferrand et al., 2014). Tā kā PKL šḳīst daudzos organiskos šḳīinātājos, tas ir daudzsološs polimērs pastāvīgiem pētījumiem audu inženierijā (Campana et al., 2014). Faktiski uz polimēriem balstīti kaulu aizvietotāji var būt dažādās formās. Akrila cementa blokus (pēc sastāva līdzīgi prepolimerizētam PMMA pulverim, kas sajaukts ar lielu šķidra metilmetakrilāta monomēra daudzumu) var modificēt vēlamajā formā, vai pirms polimerizācijas uz metakrilātiem balstītus produktus var izmantot injekciju veidā (Laurencin et al., 2006). PMMA cementi ir visplašāk izmantoti biomateriāli locītavu protēžu fikssēšanai un vertebroplastikai. Tomēr saskaṇā ar Cochrane datu bāzes pārskatu PMMA cementi, kurus izmantoja specifiskai kaulu implantācijai pēc distālā spieķkaula lūzuma, neveicina jaunu kaulu augšanu un drīzāk to var kavēt (Handoll et al., 2008). Uz polimēra bāzes kaulaudu aizvietošanas biomateriāli galvenokārt tiek izmantoti, ņemot vērā to plašo potenciālu audu inženierijā, kā arī iespējas tos izgatavot ar makroporām un mikroporām, kā arī biezu membrānu formā (De Grado et al., 2018).

\subsection{Stronciju saturošie biomateriāli}

Ir labi zināms, ka Sr ir unikāls darbības mehānisms - tas spēj palielināt jauna kaula veidošanos un vienlaikus samazināt tā noārdīšanos. Sr iedarbības rezultātā palielinās 
osteoblastu proliferācija un diferenciācija, I tipa kolagēna sintēze un kaulu matricas mineralizācija, savukārt osteoklastu diferenciācija un aktivācija tiek kavēta (Buache et al., 2012). Sr efektivitāte stroncija ranelāta medikamenta sastāvā ir pierādīta arī osteoporozes gadījumā, palielinot kaulaudu mehānisko izturību (Iolascon et al., 2014). Klīniskajos pētījumos tika pierādīts, ka stroncija ranelāta iedarbības rezultātā, ievērojami palielinās KMB un samazinās mugurkaula un gūžas kaula lūzuma risks (Tenti et al., 2014; Reginster, 2008). Diemžēl stroncija ranelātam piemīt tādas nopietnas blakusparādības, kā dziḷo vēnu tromboze un miokarda infarkta risks (Kanis et al., 2011).

Nevēlamo blakusparādību novēršanai pēc $\mathrm{Sr}$ saturošo medikamentu sistēmiskas lietošanas tika veikta $\mathrm{Sr}$ saturošo biomateriālu izveide. $\mathrm{Sr}$ saturoša biomateriāla spējas vienlaikus nomākt kaula resorbciju un veicināt jaunu kaulaudu veidošanos, ir atkarīgas no $\mathrm{Sr}$ jonu koncentrācijas (Billström et al., 2013). Grynpas et al. pētījumā žurku mugurkaula skriemeḷu tilpums palielinājās par 17\%, lietojot mazu Sr saturošo devu (0.20\%), savukārt lielākas Sr devas izraisa pretēju efektu, kavējot kaulaudu mineralizācijas procesu (Grynpas et al., 1996). Līdzīga negatīva ietekme tika novērota in vitro osteoblastos, kur lielākas Sr devas

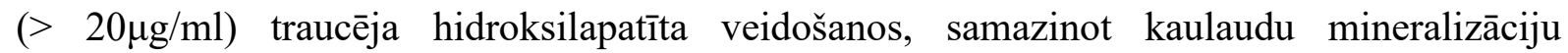
(Verbercmoes et al., 2003).

\subsection{Kalcija fosfātu saturošo materiālu bioaktivitāte}

Kaulu reǵenerācija ietver dažādus sarežǵītus bioloǵiskos procesus. Lai saprastu kaulaudu reǵenerācijas procesu, tika veikts liels eksperimentālo pētījumu daudzums, izmantojot biomateriālus in vivo un in vitro. Kalcija fosfātu saturošie biomateriāli tika pētīti daudzos pētījumos, jo tiem ir reǵeneratīvās īpašības. (Jeong et al., 2019).

Kalcija fosfāti ir minerālvielas, kas sastāv no kalcija katjoniem un fosfāta anjoniem. Tie ir pazīstami kā galvenais neorganiskais materiāls, kas veido aptuveni $60 \%$ no cilvēka kauliem. Katram implantējamam materiālam jābūt biologíski saderīgam, tas nozīmē, ka dzīvā organismā un audos nedrīkst rasties iekaisums vai svešķermeņa atrgrūšanas reakcija. Tika atklāts, ka kalcija fosfāti ir biologiski saderīgi, jo tos var izšḳīdināt organisma šķidrumos un lielos daudzumos atrodas cietās formās (Benn-Nissan, 2014).

Kalcija fosfātu īpašības ietekmē bioaktivitāti - osteoblastu adhēziju, proliferāciju un jaunu kaulu veidošanos. Lai parādītu šīs bioaktīvās īpašības, ir svarīga kalcija fosfāta jonu noārdīšanās un izdalīšanās. Šì parādība palielina kalcija un fosfātu jonu lokālo koncentrāciju un stimulē kaulu minerālvielu veidošanos uz kalcija fosfāta virsmas. Kalcija un fostāta joni ietekmē arī osteoblastu diferenciācijas marḳieru ekspresiju. Kalcija fosfātiem ir svarīga loma 
šūnu adhēzijā un audu veidošanā, ietekmējot uz virsmas esošo ārpusšūnu matricas olbaltumvielu adsorbciju (Dorozhkin, 2007).

Kalcija joni dažādos veidos ietekmē uz šūnām un dzīvu orgamismu. Kalcijs ir viens no joniem, kas veido kaulu matricu, un kaulu audos tas galvenokārt pastāv kalcija fosfātu veidā. Šie kalcija joni izraisa kaulu veidošanos un nobriešanu caur pārkaḷķošanu. Turklāt kalcija joni ietekmē kaulu reǵenerāciju, izmantojot šūnu signālus. Kalcijs stimulē nobriedušas kaulu šūnas, veidojot slāpekḷa oksīdu, un inducē kaulu augšanas prekursoru šūnas kaulaudu reǵenerācijai (Riddle et al., 2006). Kalcija joni arī stimulē osteoblastisko kaulu sintēzes ceḷu, aktivizējot ERK1/2 (Liu et al., 2008), un palielina osteoblastu dzīvildzi, aktivizējot PI3K/Akt ceḷus (Danciu et al., 2003). Turklāt kalcija joni regulē kaulu resorbciju un osteoklastu veidošanu (Asagiri et al., 2007).

Fosfora joni atrodas cilvēka ķermenī lielos daudzumos. Tie ir dažādu vielu sastāvā, piemēram, olbaltumvielās, nukleīnskābēs un adenozīntrifosfātā, un tie ietekmē fiziologisiskos procesus. Kopā ar kalcija joniem vairāk nekā $80 \%$ fosfora jonu atrodas kaulā kalcija fosfātu veidā. Fosfors galvenokārt pastāv fosfāta $\left(\mathrm{PO}_{4}{ }^{3-}\right)$ veidā, tam ir liela ietekme uz audu veidošanos un augšanu (Khoshniat et al., 2011). Fosfāts regulē osteoblastu un osteoblastiskās līnijas diferenciāciju un augšanu pa IGF-1 un ERK 1/2 ceḷiem un palielina BMP ekspresiju. Turklāt fosfātam ir negatīva atgriezeniskā mijiedarbība starp RANK-ligandu un tā receptoru signāliem, un tas regulē RANK-ligandu:OPG attiecību, lai kavētu osteoklastu diferenciāciju un kaulu resorbciju (Mozar et al., 2008).

Kaulu reǵenerācijai ir svarīgas arī kalcija fosfāta osteoinduktīvās un osteokonduktīvās īpašības. Osteovadīšana ir spēja pamudināt cilmes šūnas diferencēties osteoblastiskās līnijās, turpretī osteokondukcija ir kaulu augšanas spēja uz materiālu virsmas. Osteovadīšana un osteokondukcija veicina šūnu adhēziju un proliferāciju. Šūnu adhēziju spēcīgi ietekmē spēja adsorbēt ārpusšūnu matricas olbaltumvielas. To ietekmē kalcija fosfāta virsmas īpašības, piemēram, virsmas raupjums, kristāliskums, šķ̄ī̄ība, fāzu saturs, porainība un virsmas enerğija. Osteokondukcija un osteoindukcija ir atkarīga no vairākiem faktoriem. Daži pētījumi liecina, ka kalcija fosfātu saturošie biomateriāli ir osteoinduktīvi pat bez piemaisījumiem. Piemēram, virsmas ķīmisks sastāvs un virsmas lādiņš ietekmē olbaltumvielu adsorbciju, un osteoblastiskā diferenciācija notiek, mijiedarbojoties starp šūnām un ārpusšūnu matricu. Virsmas morfologija var arī izraisīt šos efektus (Samavedi et al., 2013).

Kalcija fosfăta virsmas raupjuma lomu nosaka graudu lielums un kalcija fosfāta kristāla struktūras daliṇu lielums. Nelīdzenums ietekmē olbaltumvielu saķeri ar kalcija fosfāta virsmu. 
Adhēzija ar olbaltumvielām uzlabojas ar biomateriāla raupjumu, kas mazāks par $100 \mathrm{~nm}$ (Deligianni et al., 2000).

Uz bioaktivitāti ietekmē arī kalcija fosfāta porainība. Porainības palielināšanās uzlabo kontaktu ar ḳermeṇa šḳidrumiem uz kalcija fostāta virsmas. Tādējādi tiek palielināts biomateriala šḳīšanas ātrums. Poru klātbūtne uz kalcija fosfāta virsmas ietekmē olbaltumvielu adsorbciju. Ir pierādīts, ka olbaltumvielu adsorbcija ir pastiprināta, ja kalcija fosfāta poru lielums ir 20-500 $\mu \mathrm{m}$. Šis efekts tika novērots arī, palielinoties poru skaitam. Papildus poru lielums ietekmē kaulaudu ieaugšanu un angioǵenēzi. Ja poru izmērs ir aptuveni $50 \mu \mathrm{m}$ vai lielāks, ir iespējama asinsvadu un kaulu ieaugšana. Poru izmēri, kas lielāki par 100 mikrometriem, ietekmē kalcija fosfāta mehānisko izturību un formu. Poru esamības dēl kalcija fosfātam piemīt tādas mehāniskās īpašības kā augsta trausluma pakāpe, zema triecienizturība un zems stiepes spriegums. Tomēr biomateriālam spiedes stiprība ir labāka nekā dabiskajam cilvēka kaulam, un to izmanto slodzi nenesošu implantu pārklāšanā un kaulu defektu aizpildīšanā (Jeong et al., 2019).

Hidrofilitāte ir kritisks osteoǵenēzes regulēšanas faktors. Hidrofilās virsmas ir būtiskas šūnu adsorbcijai un palielina fibroblastisko šūnu reakciju. Tie palielina kaulu šūnu nobriešanu un diferenciāciju, osteointegrāciju, kā arī ietekmē šūnu reakcijas. Turklāt virsmas hidrofilitāte palielina osteoblastu adhēziju un proliferāciju (Lim et al., 2004).

Kalcija fosfātu šḳišsanas procesu ietekmē virsmas laukums tilpuma vienībā, šḳidruma konvekcija, skābums un temperatūra. Tas nosaka kalcija fosfātu stabilitāti un şḳ̄īību, un parasti šḳīīiba ir apgriezti proporcionāla $\mathrm{Ca} / \mathrm{P}$ jonu attiecībai, tīrībai, kristāla lielumam un virsmas laukumam. Stabiliem un mazšķ̄istošiem kalcija fosfătiem ir zema jonu apmaiṇa ar apkārtni un lēns rekristalizācijas ātrums uz virsmas, tādējādi nosakot olbaltumvielu koncentrāciju un konformāciju ar elektrostatisko mijiedarbību uzlādētā vietā. No otras puses, kalcija fosfāti ar augstu šḳīību viegli maina vietējo $\mathrm{pH}$ un jonu koncentrāciju, ietekmējot olbaltumvielu adhēziju. Adhēzija ar olbaltumvielām izraisa šūnu adhēziju un nosaka kaulu reǵenerācijas efektivitāti (Gustavsson et al., 2014). 


\section{Materiāls un metodes}

\subsection{Pētījuma materiāls}

\subsubsection{Dzīvnieku modelis}

Pētījumā tika izmantoti 34 astoṇus mēnešus veci sieviešu dzimtes eksperimenta dzīvnieki - "Kalifornijas" un "Lielais marders" šķirnes truši no trušu audzētavas "Podziņas”, Ādažu novads, Latvija, LV-2164, novietnes Nr. 1382580, ganāmpulka Nr. LV06178330 (RSU Iepirkuma komisijas lēmums Nr. 5-2/80 (17.02.2015.)) ar vidējo svaru pirms eksperimenta 3,87 $\operatorname{kg}(2,9-5,0)$.

Dzīvnieki tika turēti Rīgas Stradina universitātes Eksperimenta dzīvnieku audzētavā (faktiskā adrese: Kristapa Helmaņa iela 8, Jelgava, LV-3004). Stacionārs $\left(32,8 \mathrm{~m}^{2}\right)$ un ķirurğijas zāle $\left(62,0 \mathrm{~m}^{2}\right)$ tika nomāti no Latvijas Lauksaimniecības universitātes uz līguma Nr. 4.4.-9/15/2015 pamata. Pētījuma laikā tika ievērotas prasības saskaṇā ar Ministru kabineta noteikumiem Nr.52 "Noteikumi par zinātniskiem mērḳiem izmantojamo dzīvnieku aizsardzību”. Dz̄̄vnieki tika izmitināti pa vienam $100 \times 45 \times 62 \mathrm{~cm}$ izmēra būros. To barībai izmantoja pḷavas sienu un auzas, savukārt dzirdināšanai - krāna ūdeni. Eksperimenta laikā visiem trušiem tika atḷautas brīvprātīgas kustības, bija pieejams ēdiens un ūdens jebkurā brīdī.

Eksperimentāla osteoporoze tika izraisīta 24 trušiem pēc ovariektomijas un sekojošas metilprednizolona injekcijas. Viens trusis exitus letalis 28. dienā pēc metilprednizolona kursa uzsākšanas laika. Kontroles grupā bija 10 veseli truši. Biomateriālu implantācijas operācijas un dzīvnieku eitanāzija tika veikta laika posmā no 2016. gada 20. februāra līdz 2016. gada 13. maijam.

\section{Eksperimentālās osteoporozes ierosināšanas protokols}

Eksperimentālā osteoporoze tika ierosināta uz iepriekš zinātniskajā literatūrā aprakstītās metodologijas principiem (Baofeng et al., 2010; Wanderman et al., 2018). Ķirurğiskās manipulācijas tika veiktas vispārējā anestēzijā, izmantojot ketamīna $10 \%$ šḳīumu devā 30 $\mathrm{mg} / \mathrm{kg}$ ķermeṇa svara, ksilazīna $2 \%$ šķīiumu devā $3 \mathrm{mg} / \mathrm{kg}$ ķermeṇa svara, atropīna 0,1\% šķ̄īumu devā 0,1-0,5 mg/kg ķermen,a svara. Ķirurǵijas pirmajā posmā pēc operācijas lauka sagatavošanas tika veikts $3 \mathrm{~cm}$ grieziens vēdera priekšējā sienā pie nabas pa viduslīniju (operēja prof. A. Skaǵers, asoc. prof. Ģ. Šalms). Tika atvērts vēdera dobums, atrastas un pēc lig̣ēšanas pie pamatnes nogrieztas olnīcas, pārbaudīta hemostāze (2.1. att.). 


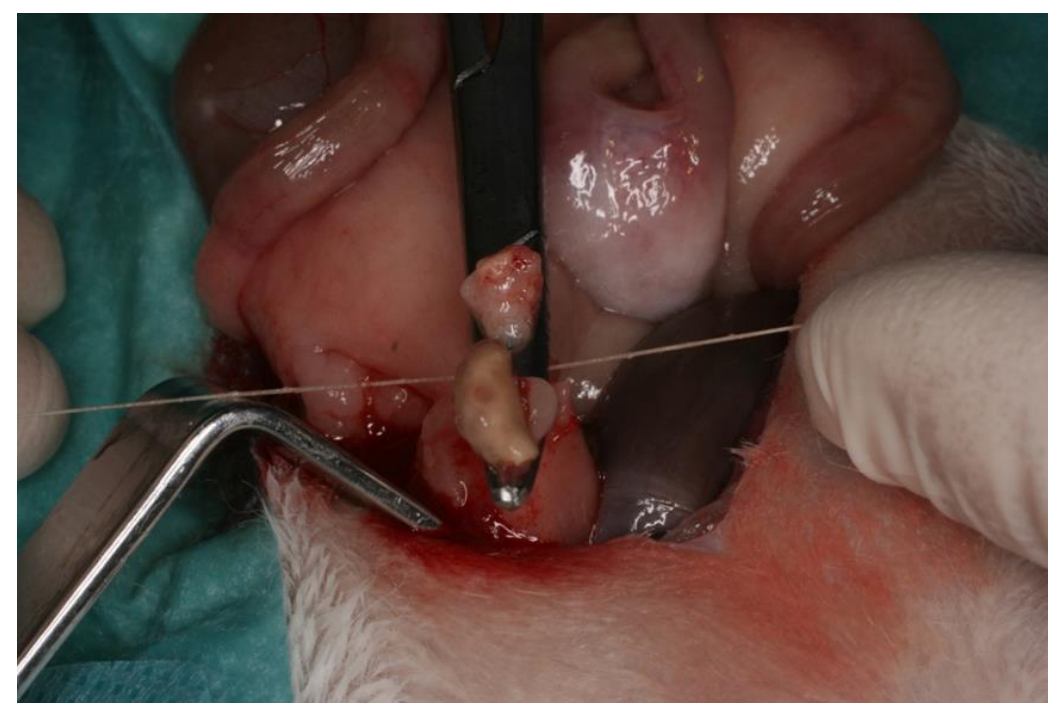

\section{1. att. Abpusējās ovariektomijas operācija} (fotogrāfija no doc. I. Šalmas personīgā arhīva)

Vēdera siena tika slēgta divās kārtās ar resorbējošiem 4/0 diegiem. Āda tika slēgta bez iesprieguma ar neresorbējošiem 4/0 diegiem, kuri tika noṇemti desmitajā pēcoperācijas dienā. Sāpes pēcoperācijas periodā tika kontrolētas, subkutāni injicējot ketoprofēnu 1-3 mg/kg vienu reizi dienā trīs pirmās dienas.

Kad brūce bija sadzijusi un dz̄ivnieka veselības stāvoklis normalizējies, pēc 14 dienām tika uzsākts 6 nedēḷ metilprednizolona kurss intramuskulāri $1 \mathrm{mg} / \mathrm{kg}$ dienā. Metilprednizolona kursa laikā dz̄̄vnieki saṇēma hepatoprotektoru Hepatiale Forte 170 mg dienā (fosfolipīdi 85 mg, L-ornitīna L-aspartāts $85 \mathrm{mg}$ ).

Medikamentu izvēle un devas balstītas uz LLU Veterinārmedicīnas Preklīniskā institūta asociētās profesores Aijas Ilgažas ieteikumiem un datiem no James W. Carpenter "Exotic Animal Formulary" un Ian Ramsey "BSAVA Small Animal Formulary”. Veterināro medikamentu izmantošanu trušiem veica veterinārārste Jekaterina Petḷa, kura arī uzṇēmās nodrošināt eksperimenta dzīvnieku labturīgu aprūpi pēcoperācijas periodā.

\section{Kaula defekta veidošana placebo paraugiem un ar biomateriālu implantāciju}

K,irurğijas otrajā posmā labā augšstilba trochanter major rajonā vispārējā anestēzijā tika veikts aptuveni $2 \mathrm{~cm}$ garš grieziens, atslān,oti mīkstie audi un periosts (2.2. att.). 


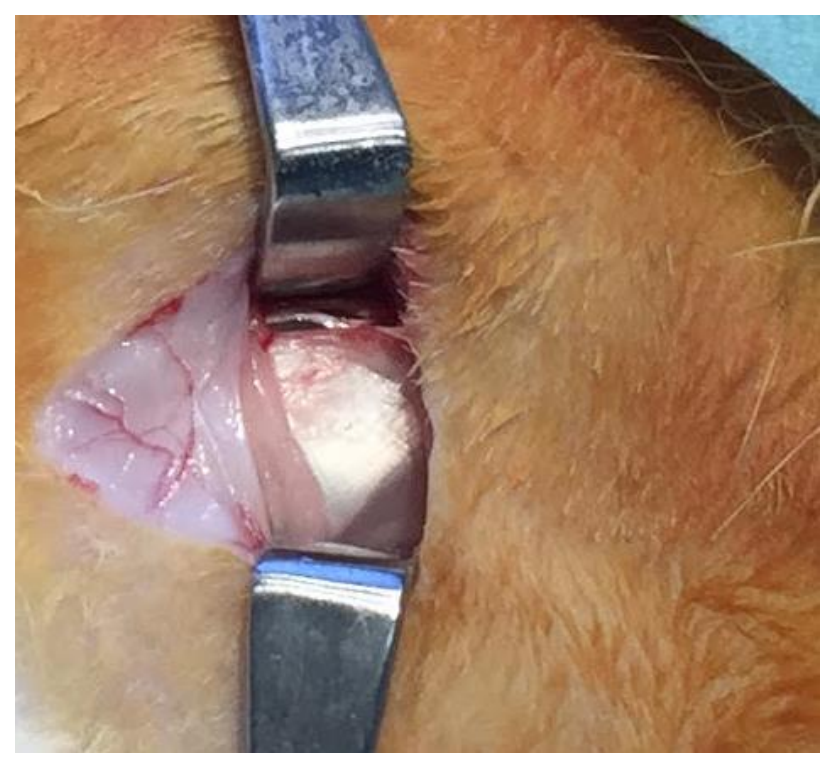

2.2. att. Labā augšstilba trochanter major rajons (fotogrāfija no doc. I. Šalmas personīgā arhīva)

Ar trepāna urbi 5 mm diametrā un 4 mm dziḷumā tika izveidots apaḷ̌s defekts augšstilba lielā grozītāja rajonā (2.3. att.).

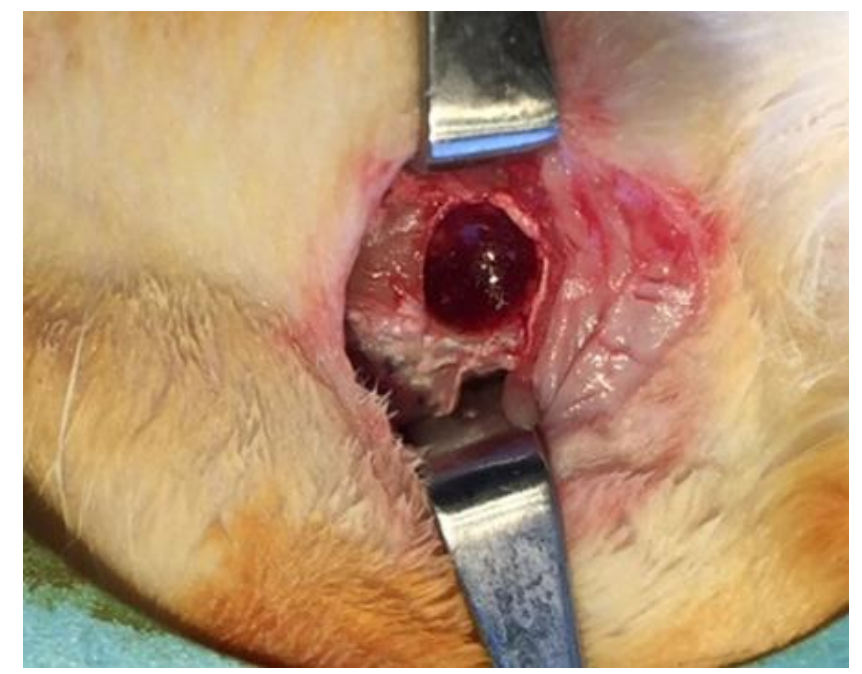

2.3. att. Kaula defekts $5 \times 4 \mathbf{~ m m}$ apjomā augšstilba lielā grozītāja rajonā (fotogrāfija no doc. I. Šalmas personīgā arhīva)

23 eksperimentālie dzīvnieki tika iedalīti trīs grupās: 1. grupa ( 8 truši $)$ - defekti tika aizpildīti ar HAP/TCP (70/30) granulām, 2. grupa (8 truši) - defekti tika aizpildīti ar HAP/TCP (70/30) granulām, kam pievienoti $5 \%$ stroncija, 3. placebo ķirurğijas grupa (7 truši) - defekti tika radīti, bet materiāls netika ielikts (2.4. att.). 


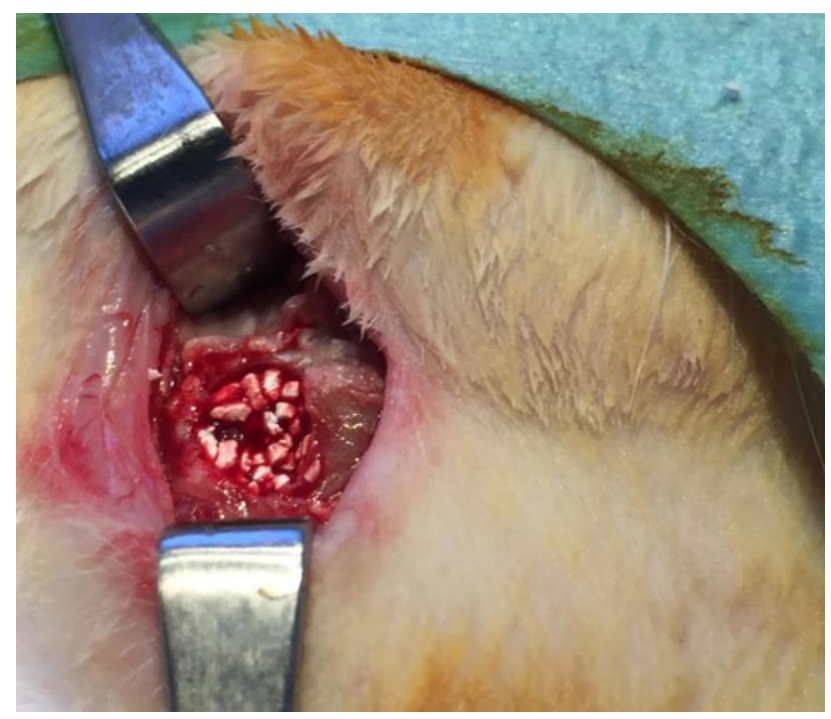

2.4. att. Biomateriāla implantācija augšstilba trochanter major rajonā

(fotogrāfija no doc. I. Šalmas personīgā arhīva)

Virs kaula defekta periosts tika slēgts ar uzsūcošiem 4/0 diegiem; āda slēgta bez iesprieguma ar neresorbējošiem 4/0 diegiem, kuri tika noṇemti desmitajā pēcoperācijas dienā (2.5. att.).

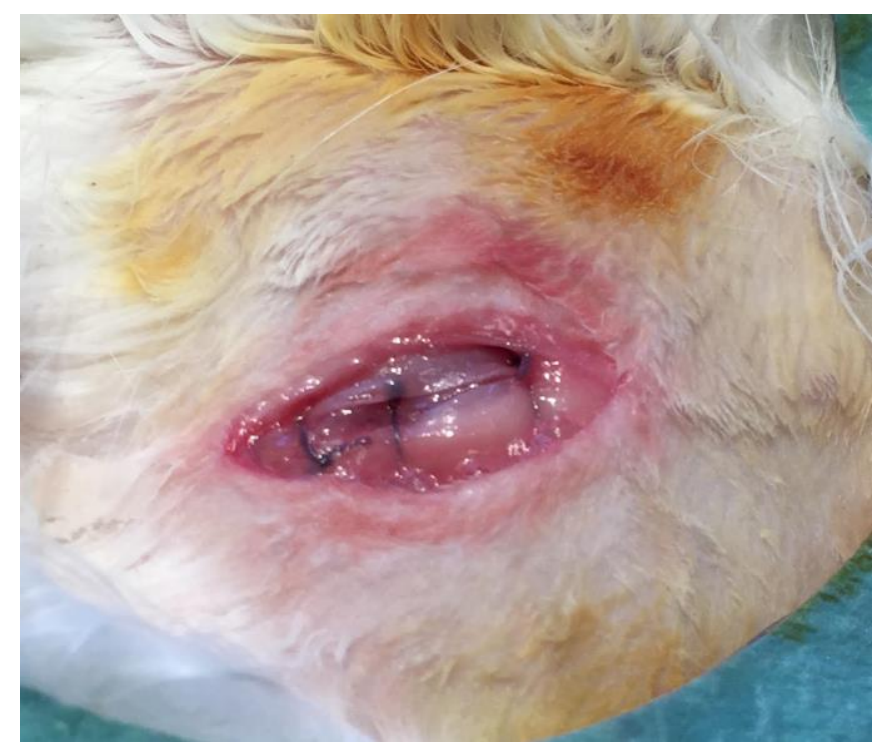

\section{5. att. Periosta slēgšana ar uzsūcošiem diegiem} (fotogrāfija no doc. I. Šalmas personīgā arhīva)

Dzīvniekiem tika veikta novērošana, novērtējot ūdens un ēdiena patēriņu, svara izmaiṇas, šuvju, brūču stāvokli, dz̄ivnieku uzvedību, ārējo izskatu. Eksperimenta laikā netika novērotas fiziskās aktivitātes vai apetītes zudums. 


\section{Dzīvnieku eitanāzija un kaulu paraugu ņemšana}

Dzīvnieku eitanāzija tika veikta trīs mēnešus pēc kaula defekta veidošanas vispārējā anestēzijā, ievadot preparātu T-61 intrapulmonāli, deva $1,0 \mathrm{ml} / \mathrm{kg}$ ķermeṇa svara. Lai iegūtu statistiski ticamus rezultātus, minimālais paraugu skaits bija vairāk nekā 6 (Yamada, 1970; Evans, 1971; Charan et al., 2013).

Osteoporozes pierādīšanai ar morfologiskā pētījuma metodi tika ņemti 10 apakšžokḷa kaula premolāra rajona paraugi no veseliem trušiem un 23 apakšžokḷa kaula premolāra rajona paraugi no trušiem ar eksperimentālo osteoporozi. Lai noteiktu biomateriālu lokālo ietekmi, tika izmantoti 23 labā (operētā) augšstilba kaula paraugi no trušiem ar eksperimentālo osteoporozi, kā arī 23 kreisā (neoperētā) augšstilba un 23 apakšžokḷa kaula leṇķa rajona paraugi no trušiem ar eksperimentālo osteoporozi, lai noteiktu sistēmisku biomateriāla iedarbību ar biomehāniskā un rentgenologisiskā pētījuma metodēm (2.6. att.).

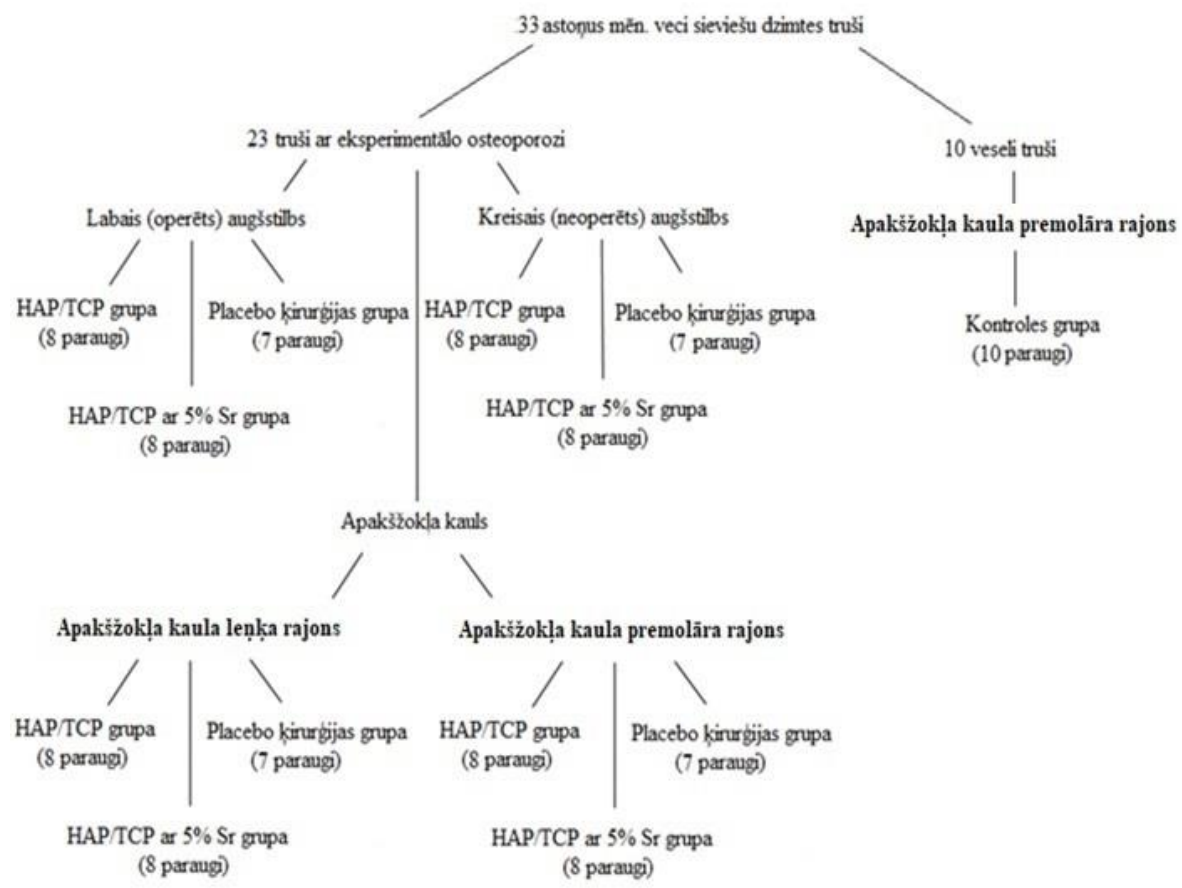

2.6. att. Trušu kaulu paraugu sadalījuma shēma

\subsubsection{Biomateriālu sagatavošana}

Pētījumam tika izmantoti nekomerciālie Rīgas Tehniskās universitātes Rūdolfa Cimdina Rīgas biomateriālu inovāciju un attīstības centrā ražoti biomateriāli. Kalcija fosfāta materiālu sintēze un granulu izgatavošana tika realizēta, kā iepriekš aprakstīts zinātniskajā literatūrā (Grybauskas et al., 2016; Zarins et al., 2017). Pirms kalcija fosfātu sintēzes CaO (Fluka) un $\mathrm{SrO}$ (Sigma-Aldrich) aktivēšanas nolūkos tiek termiski apstrādāts augsttemperatūras krāsnī $1100{ }^{\circ} \mathrm{C}$ temperatūrā vienu stundu. No iegūtā kalcija oksīda un stroncija oksīda tika 
pagatavota $0,3 \mathrm{M} \mathrm{Ca}(\mathrm{OH})_{2}$ vai $\mathrm{Sr}(\mathrm{OH})_{2} / \mathrm{Ca}(\mathrm{OH})_{2}$ suspesija dejonizētā ūden̄̄. Kalcija fosfātu sintēze tika veikta reaktorā, hidroksīdu suspensijām to maisīšanas laikā pievienojot $2 \mathrm{M} \mathrm{H}_{3} \mathrm{PO}_{4}$ tādā daudzumā, lai iegūstamā produkta HAP/TCP fāžu attiecība pēc augsttemperatūras apstrādes būtu 70/30. Pēc sintēzes nogulsnes tika filtrētas un granulētas, izmantojot manuālu ekstrūzijas paṇēmienu. Iegūtās granulas tika žāvētas un apdedzinātas $1150{ }^{\circ} \mathrm{C}$ temperatūrā divas stundas. Termiski apstrādātās granulas tika sadalītas pa frakcijām, tās sijājot ar vibrējošo sietu iekārtu, izmantojot sietus ar $1000 \mathrm{mkm}$ un $500 \mathrm{mkm}$ acu izmēru, tādējādi iegūstot nepieciešamo granulu frakciju (no 0,5 līdz $1 \mathrm{~mm}$ ). Pēc sijāšanas granulas vairākkārt tika skalotas etanolā, lai atdalītu smalkākās dalininas, un žāvētas $+70{ }^{\circ} \mathrm{C}$ temperatūrā.

Eksperimenta pētījumam in vivo biomateriāls pēc izgatavošanas tika testēts ar fizikāli ķīmiskām un šūnu kultūrās in vitro, atlasot maztoksiskākās, biosaderīgākās un osteogēnas bioaktivitātes ziṇā efektīvākās dalinnas.

Biomateriālu granulu raksturojošie parametri atrodami 2.1. tabulā.

2.1. tabula.

Biomateriālu granulu raksturojošie parametri.

\begin{tabular}{|c|c|c|c|c|}
\hline Biomateriāls & $\begin{array}{c}\text { Virsmas laukums, } \\
\mathrm{m}^{2} / \mathrm{g}\end{array}$ & $\begin{array}{c}\text { Tilpuma blīvums, } \\
\mathrm{g} / \mathrm{cm}^{3}\end{array}$ & $\begin{array}{c}\text { HAP/TCP saturs, } \\
\%\end{array}$ & $\begin{array}{c}\text { Sr saturs, } \\
\%\end{array}$ \\
\hline $\begin{array}{c}\text { HAP/TCP } \\
\text { (70/30) }\end{array}$ & $1.262 \pm 0.014$ & $0.98 \pm 0.01$ & $73 / 27$ & $0.017 \pm$ \\
& & $1.05 \pm 0.02$ & $71 / 29$ & 6.002 \\
\hline $\begin{array}{c}\text { HAP/TCP ar } \\
\mathrm{Sr}(70 / 30)\end{array}$ & $1.124 \pm 0.0147$ & 0.7 \\
\hline
\end{tabular}

Apzīmējums: HAP - hidroksilapatīts, TCP - trikalcija fosfāts, $\mathrm{Sr}$ - stroncijs

\subsection{Pētījuma metodes}

\subsubsection{Biomehāniskā pētījuma metode}

Pētījumā kaulaudu biomehānisku parametru noteikšanai tika veikts trīs punktu lieces izpētes tests (Prodinger et al., 2018), (2.7. att.).

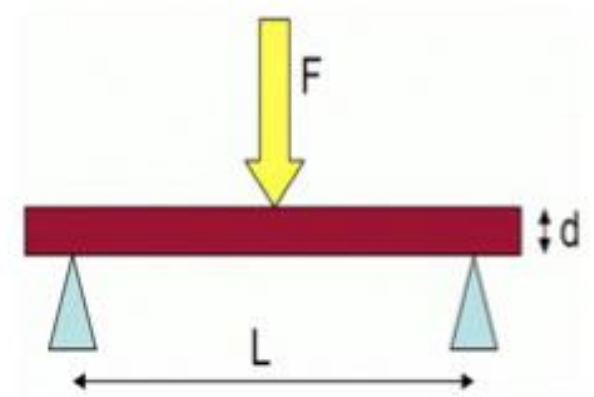

2.7. att. Parauga trīs punktu lieces izpētes testa shēma:

F - slogojums, L - laidums, d - parauga biezums 
Lieces laikā katram paraugam tika noteikts graujošais (maksimālais) spriegums ( $\left.\sigma^{*}\right)$ un graujošā (maksimālā) deformācija ( $\left.\varepsilon^{*}\right)$. Datorprogramma mērījumu rezultātus atspoguḷoja tabulas veidā un grafiski kā sprieguma-deformācijas līkni. Paraugu cietība tika izteikta kā pieskares lieces modulis uz noteiktas sprieguma-deformācijas līknes lineārās daḷas kā tangensa leṇkiis $\alpha(\operatorname{tg} \alpha)$, kurš veidojas starp koordinātu asi un pieskares līkni tās lineārajā daḷā (2.8. att.).

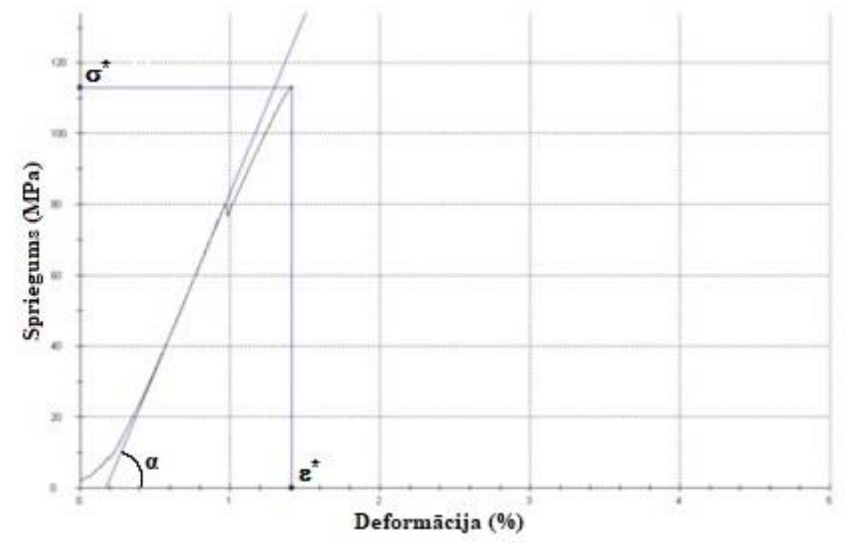

2.8. att. Tipiskā eksperimentālā sprieguma-deformācijas sakarība un galvenie nosakāmie mehāniskie parametri: $\sigma^{*-}$ graujošais spriegums, $\varepsilon^{*}-$ graujošā deformācija, $\operatorname{tg} \alpha$-lieces modulis

Graujošais spriegums tika aprēḳināts pēc formulas:

$$
\sigma=3 \mathrm{FL} /\left(2 \mathrm{bd}^{2}\right)
$$

kur F - slogojums, L - laidums, $\mathrm{b}$ - parauga platums, $\mathrm{d}$ - parauga biezums.

Graujošais spriegums tika mērīts paskālos (Pa).

Graujošă deformācija tika aprēḳināta pēc formulas:

$$
\varepsilon=6 \mathrm{df} / \mathrm{L}^{2},
$$

kur $\mathrm{d}$ - parauga biezums, $\mathrm{f}$ - parauga noliece un $\mathrm{L}$ - laidums.

Graujošā deformācija tika noteikta procentos (\%).

Liecies modulis tika aprēķināts pēc formulas:

$$
\mathrm{E}=\mathrm{FL}^{3} /\left(4 \mathrm{fbd}^{3}\right),
$$

kur $\mathrm{F}$ - slogojums, $\mathrm{L}$ - laidums, $\mathrm{f}$ - parauga noliece, $\mathrm{b}$ - parauga platums, $\mathrm{d}$ - parauga biezums.

Lieces modulis tika mērīts paskālos (Pa). 
Lieces modulis tika aprēḳināts sprieguma-deformācijas līknes lineārajā daḷā relatīvā parauga deformācijas laikā $(\varepsilon=0,5 \%)$.

Kaulaudu biomehānisko īpašǐbu izpētei par trīs punktu lieci tika izmantoti taisnstūra formas paraugi. Pielietojot fiziodispenseri Surgic Pro (NSK, Japāna), taisno galu un dimanta diska urbi ar diametru 5 mm, tika izveidoti taisnstūra formas kaulaudu bloki (2.9. att.).

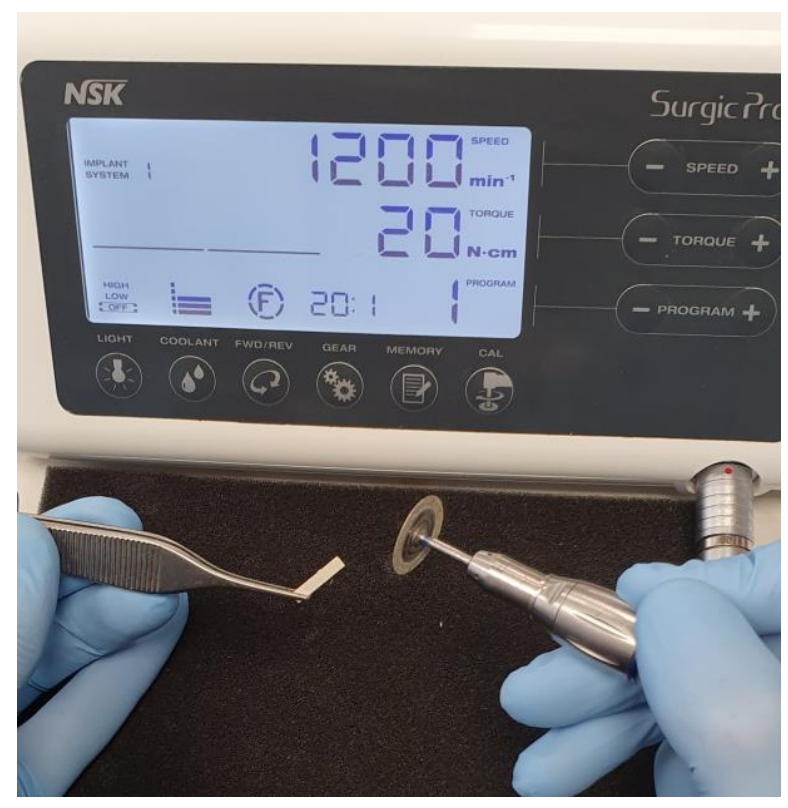

2.9. att. Surgic pro fiziodispansers taisnstūra formas kaulu paraugu iegūšanai (fotogrāfija no darba autora person̄̄gā arhīva)

Taisnstūra formas kaula paraugi tika iegūti no operēta augšstilba kaula diafīzes daḷas, neoperēta augšstilba kaula diafĩzes daḷas un apakšžokḷa kaula leṇķa rajona (2.10. att.).
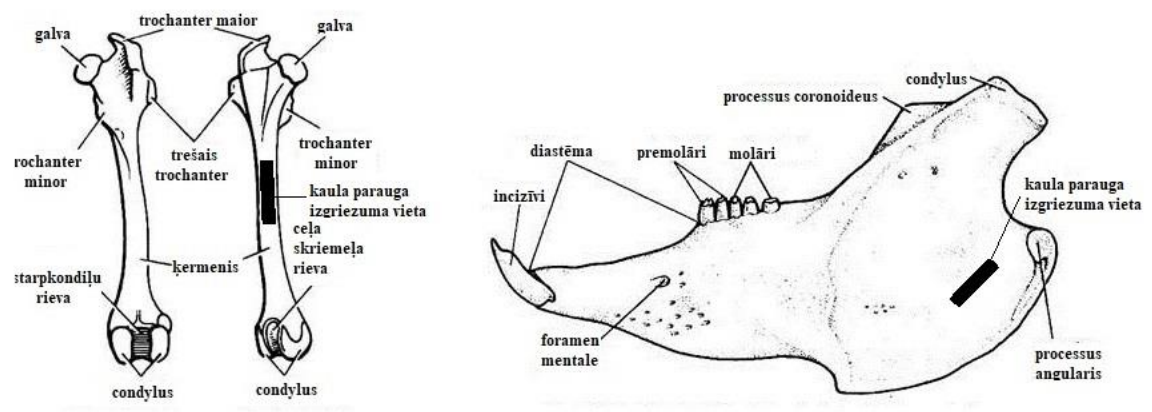

2.10. att. Shematisks trušu augšstilba un apakšžokḷa kaula zīmējums ar melno taisnstūri apzīmēta kaula paraugu izgriezuma vieta

(Endoskeleton of Rabbit (With Diagram). NotesOnZoology.com, Fig. 29.11 un 29.19.

(http://www.notesonzoology.com/rabbit/endoskeleton/endoskeleton-of-rabbit-with-diagram-vertebrateschordata-zoology/7690)) 
Visi paraugi tika pielīdzināti vienam lielumam, izmantojot speciāli izgatavotu ierīci paraugu kalibrēšanai un abrazīvo slīpēšanas disku: augšstilba kaula paraugu platums $3,2 \pm 0,02$ $\mathrm{mm}$, biezums $0,61 \pm 0,02 \mathrm{~mm}$; apakšžokḷa kaula paraugu platums $3,2 \pm 0,02 \mathrm{~mm}, 0,32 \pm 0,02$ mm biezums. Speciāla ierīce paraugu kalibrēšanai tika izgatavota un kalibrēta "Liepadent" zobu tehniskajā laboratorijā. Paraugi, kuri neatbilda noteiktiem izmēriem, netika izmantoti pētījumā (2.11. att.).

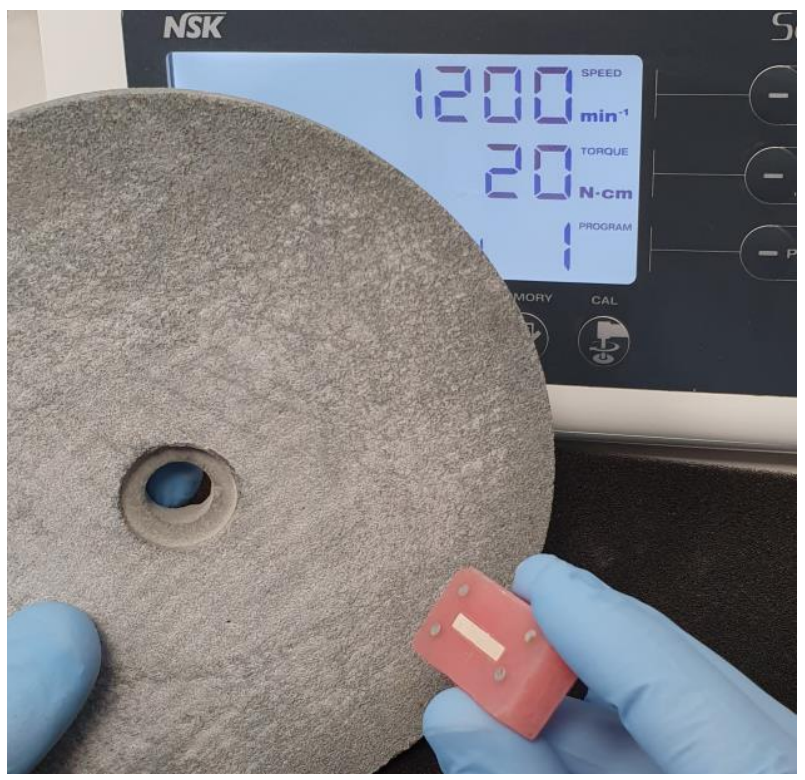

2.11. att. Speciāli izgatavota ierīce paraugu kalibrēšanai un abrazivais slīpēšanas disks kaulu paraugu pielīdzināšanai

(fotogrāfija no darba autora personīgā arhīva)

Kaulu paraugu platums un biezums tika izmērīts ar katetometru KM-6 (Lomo, Krievija), mērījuma precizitāte $\pm 0,01 \mathrm{~mm}$ (2.12. att.). 


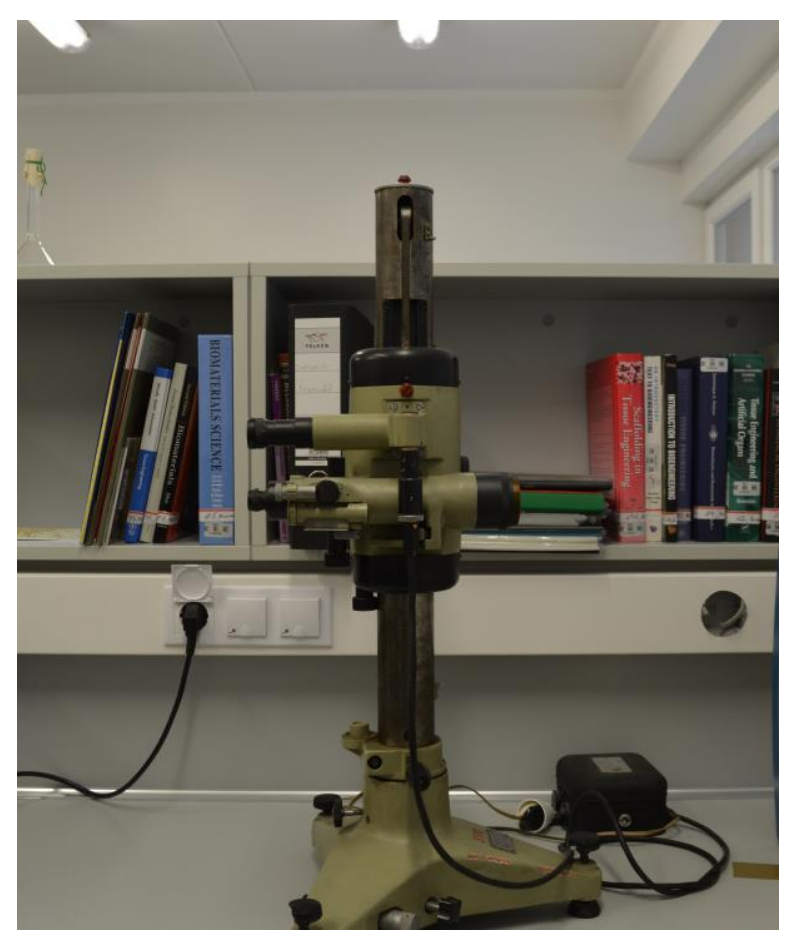

2.12. att. KM-6 katetometrs, mērījuma precizitāte $\pm 0,01 \mathrm{~mm}$ (fotogrāfija no darba autora personīgā arhīva)

Kaulu paraugi tika mērīti $550 \mathrm{~mm}$ attālumā no katetometra (2.13. att.).

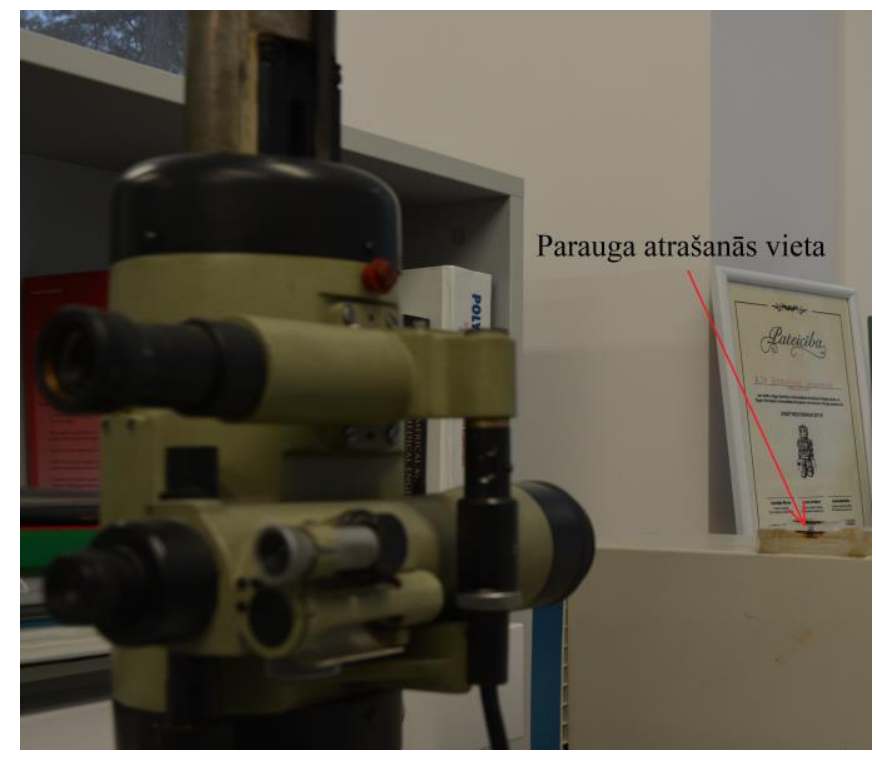

2.13. att. Kaulu parauga platuma un biezuma mērījumu iegūšana (fotogrāfija no darba autora personīgā arhīva)

Paraugu lieces izpēte tika veikta stendā Zwick/Roell (BT1-FR2.5TN.D14, Vācija), kas aprīkots ar 2,50 $\pm 0,1 \mathrm{kN}$ spēka tenzodevēju (2.14. att.). 


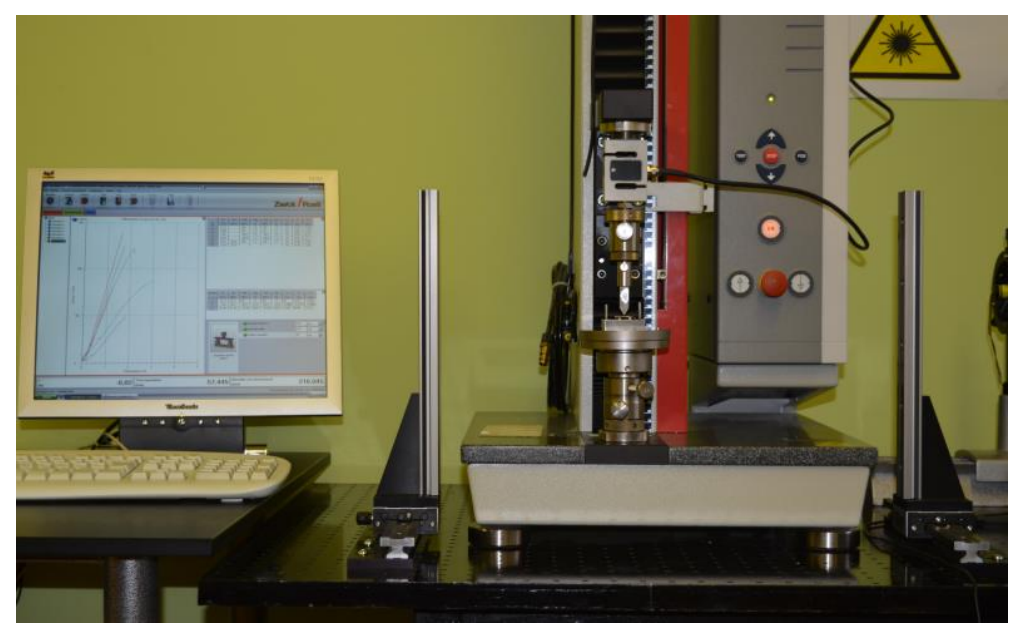

2.14. att. Zwick/Roell lieces izpētes stends

(fotogrāfija no darba autora person̄̄gā arhīva)

Kaulu paraugi tika ielikti $10 \mathrm{~mm}$ attālumā starp atbalstiem (2.15. att.).

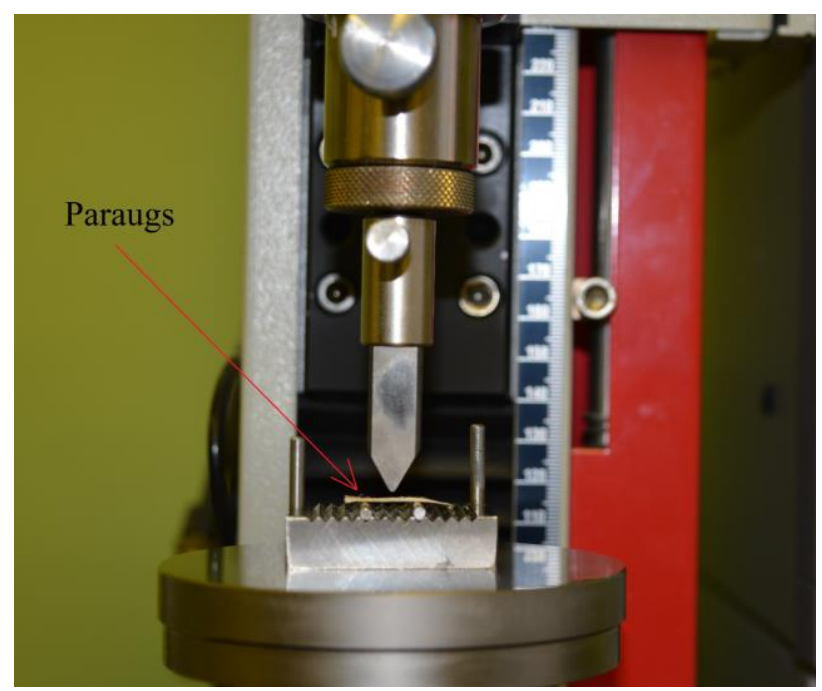

2.15. att. Parauga izpēte par trīs punktu lieci

(fotogrāfija no darba autora personīgā arhīva)

Stends tika izmantots kopā ar datorprogrammu testXpert 2.5 (Vācija), kas paredzēta testēšanas ierīces vadīšanai un datu apstrādei. Paraugi tika deformēti ar ātrumu $1 \mathrm{~mm} / \mathrm{min}$ līdz parauga sabrukšanai. Noslogojuma stendā iegūtie dati tika apstrādāti ar testXpert 2.5 programmu.

Katrā sprieguma-deformācijas līknes punktā pēc stenda spiediena uzgaḷa pārvietošanas programma automātiski aprēḳināja parauga nolieci. Pēc formulām, kuras tika ievadītas programmā, automātiski tika aprēḳināts graujošais spriegums, graujošā deformācija un lieces modulis.

\subsubsection{Rentgenoloğiskā pētījuma metode}


Operēta un neoperēta augšstilba ķermeņa kortikālā kaula blīvums tika mērīts ar konusa staru datortomogrāfijas palīdzību, izmantojot iCAT Next Generation aparatūru (Kavo, Vācija), (2.16. att.).

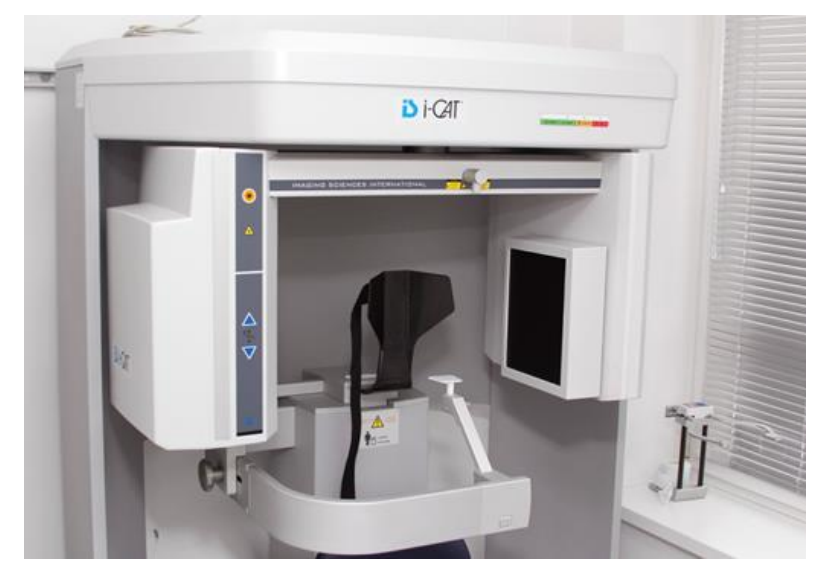

2.16. att. iCAT Next Generation aparatūra konusa stara datortomogrāfijas attēla iegūšanai (fotogrāfija no darba autora personīgā arhīva)

Aparatūra tika izmantota, vadoties pēc standarta darbības protokola (spriegums $120 \mathrm{KV}$, strāvas stiprums $38 \mathrm{~mA}$, izmeklēšanas lauks (FOV) $17 \mathrm{~cm}$, izšķirtspēja 0,4 vokseḷi (trīsdimensiju attēla tilpuma mērvienība)). Iegūtie testa dati tika apstrādāti un analizēti, izmantojot aparatūrai specifisko programmatūru iCAT eXamVision (Kavo, Vācija). Paraugiem tika noteiktas attēla vokseḷa nomelnējuma līmeņa vērtības. Vērtības, kas tika parādītas Haunsfìlda vien̄̄bās $(H U)$, tika pārveidotas $1: 1$ radioloǵiskās vokseḷa nomelnējuma līmeņa vērtības vienībās (Do-Gyoon Kim, 2014). Attēla nomelnējuma līmeṇa vērtība tika noteikta $4 \mathrm{~mm}^{2}$ lielā laukā (2.17. att.).

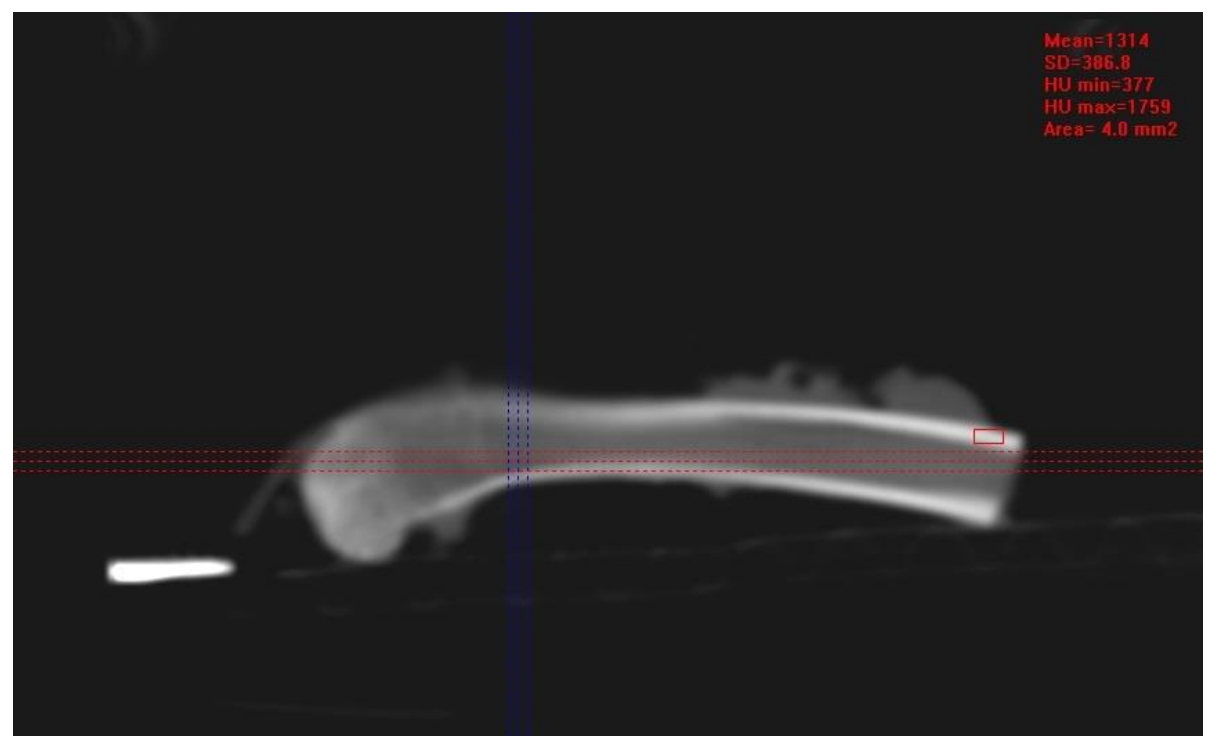

2.17. att. Konusa stara datortomogrāfijas attēls radiologiskā attēla nomelnējuma blīvuma vērtības noteikšanai augšstilba ḳermeṇa kortikālajā kaulā - sagitālajā plaknē. Sarkanās līnijas koronārā plakne, zilās līnijas - aksiālā plakne. Ar sarkano taisnstūri atzīmēts izmeklējamais lauks. Augšêjā labajā stūrī var redzēt nosaukumus un parametrus: Mean - vidējais kaula minerālblīvums izmeklējamā laukā; SD - standarta deviācija; $H U$ min - minimālais kaula 
minerālblīvums izmeklējamā laukā; $H U$ max - maksimālais kaula minerālblīvums izmeklējamā laukā; Area - izmeklējamā lauka lielums

\subsubsection{Morfologisiskā pētîjuma metode}

Pētījumā tika izmantota klasiskā audu sagatavošanas metode 33 kaulaudu paraugiem no apakšžokḷa premolāra rajona. Kaulaudu morfoloğiskajai izpētei tika izmantota rutīnizmeklēšanas metode ar hematoksilīnu/eozīnu (Kiernan, 2015).

Pēc kaulaudu bloku izdalǐšanas audi tika ievietoti fiksējošă šḳīdumā - 10 \% formalīnā uz divām nedēlāām. Pēc fiksācijas kaulaudi tika dekalcinēti ar Osteodec šḳīdumu (Bio-medica, Itālija), tad audi tika atūdeņoti, pielietojot etilspirtu, un attaukoti ksilola šķ̄īumā. Pēc tam audi tika ieguldīti kasetēs ar parafīnu, izveidojot parafīna blokus, no kuriem tika sagatavoti 3-5 $\mu \mathrm{m}$ biezi griezumi un uzklāti uz priekšmetstikliem turpmākai apstrādei un krāsošanai ar hematoksilīnu/eozīnu.

Trabekulārā kaula laukums tika izmērīts, izmantojot datorprogrammu Image Pro Plus 7 (Media Cybernetics, ASV). Visos kaulaudu paraugos pēc nejaušības principa tika izvēlēti trīs vienādi redzamības lauki $\left(0,975 \mathrm{~mm}^{2}\right)$.

\subsection{Datu statistiskās apstrādes metodes}

Visu datu statistiskā apstrāde, aprēḳināšana un grafiskais attēlojums tika veikts ar speciālas programmatūras GraphPad PRISM v.6.0e (GraphPad Software Inc., Sandjego, Kalifornija, ASV) palīdzību. Dispersijas homogenitāte tika pārbaudīta ar Brown-Forsythe un Bartiett testu palīdzību. Nevienmērīga sadalījuma gadījumā dažādu grupu skaitlisko mainīgo vērtību vidējās vērtības tika salīdzinātas, izmantojot neparametrisko kritēriju ANOVA testu jeb Kruskal-Wallis testu un kā post-hoc procedūru pēc tam pielietoja Benjamini, Krieger un Yekutieli metodi.

Visi rezultāti tika izteikti kā mediānas (Md) ar starpkvartiḷu diapazonu (IQR). Divi lielumi tika uzskatīti par statistiski nozīmīgi atšķirīgiem, ja starpības ticamības līmenis starp tiem bija lielāks par 95\% $(\mathrm{p}<0,05)$. 


\section{Rezultāti}

\subsection{Biomehāniskā pētījuma un datu statistiskās apstrādes rezultāti augšstilba kaula paraugos}

Visi kaula paraugi, kuri tika izmantoti augšstilba kaulu biomehānisko parametru noteikšanai, tika iedalīti trīs grupās:

1) placebo ķirurğijas grupa: labajā augšstilbā trochanter major rajonā tika radīts defekts, bet materiāls netika ielikts;

2) HAP/TCP grupa: labajā augšstilbā trochanter major rajonā defekts tika aizpildīts ar HAP/TCP (70/30) granulām;

3) $\mathrm{HAP} / \mathrm{TCP} / 5 \% \mathrm{Sr}$ grupa: labajā augšstilbā trochanter major rajonā defekts tika aizpildīts ar HAP/TCP (70/30) granulām, kam pievienoti $5 \%$ stroncija.

\subsubsection{Graujošās deformācijas noteikšanas un datu statistiskās apstrādes rezultāti}

Operēta augšstilba placebo ķirurǵijas grupas paraugiem graujošā deformācija bija 1,43 $(1,57-1,20) \%$, kas ir statistiski ticamāki lielāks nekā HAP/TCP grupas paraugiem 1,16 $(1,18-1,13) \%, \mathrm{p}=0,002$, un HAP/TCP/5 \% Sr grupas paraugiem $1,04(1,14-0,86) \%, \mathrm{p}=$ 0,005. Tika atrastas statistiski ticamas graujošās deformācijas atšķirības starp HAP/TCP un HAP/TCP/5 \% Sr grupas paraugiem: HAP/TCP grupas kaulu paraugu graujošā deformācija ir lielāka nekā HAP/TCP/5 \% Sr grupas kaulu paraugu graujošā deformācija, p = 0,02 (3.1. att.).

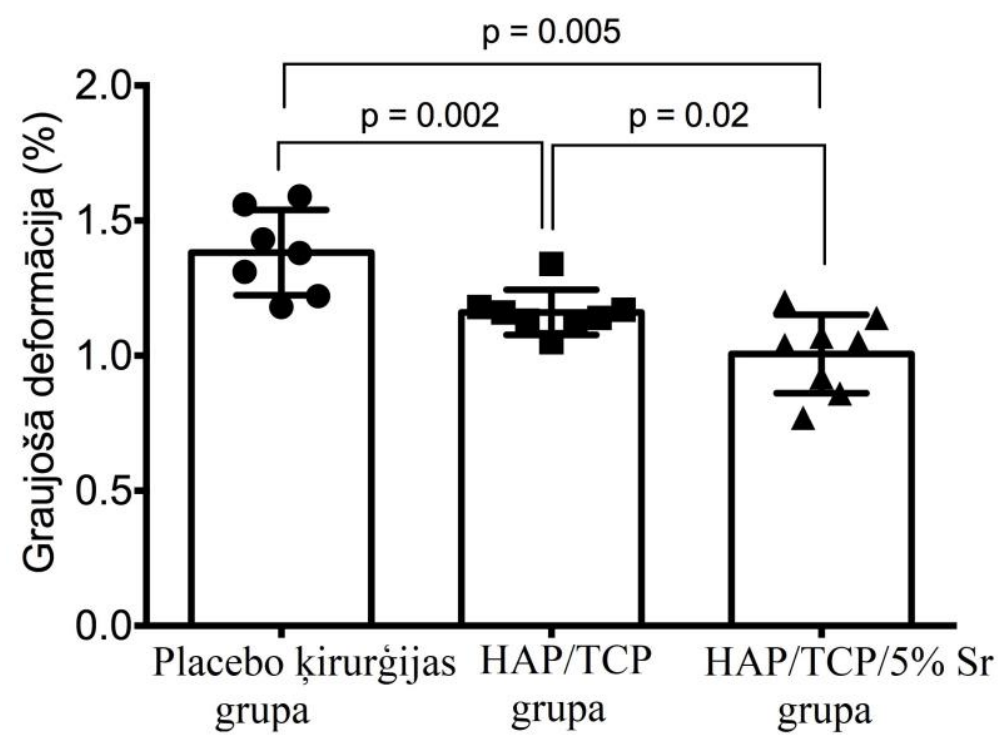

3.1. att. Operēta augšstilba paraugu graujošā deformācija dažādām grupām

Neoperēta augšstilba placebo ķirurğijas grupas paraugiem graujošā deformācija bija $1,27(1,42-1,17) \%$, kas ir statistiski ticamāki lielāka nekā HAP/TCP grupas paraugiem 1,06 $(1,15-0,93) \%, \mathrm{p}=0,012$, un HAP/TCP/5 \% Sr grupas paraugiem 1,02 $(1,14-0,9) \%, \mathrm{p}=0,003$. 
Statistiski ticamas graujošās deformācijas atškirības starp HAP/TCP un HAP/TCP/5 \% Sr grupas paraugiem netika atrastas, $\mathrm{p}=0,64$ (3.2. att.).

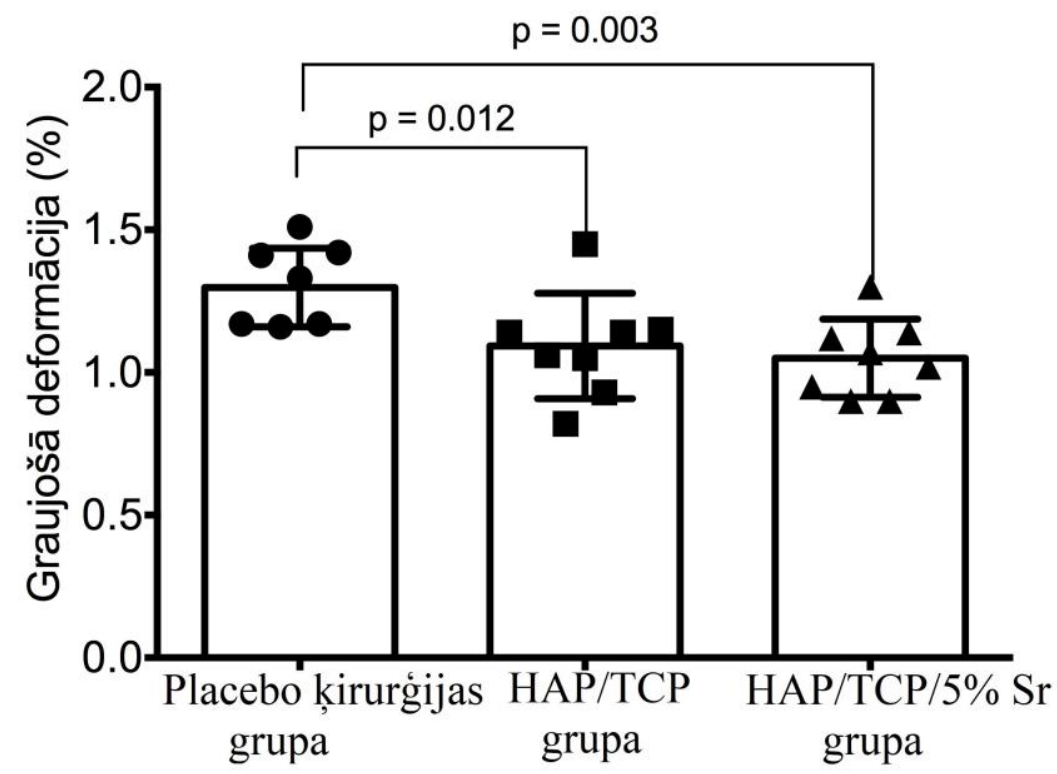

3.2. att. Neoperēta augšstilba paraugu graujošā deformācija dažādām grupām

\subsubsection{Graujošā sprieguma noteikšanas un datu statistiskās apstrādes rezultāti}

Operēta augšstilba paraugu statistiski ticamas graujošā sprieguma atšķirī̄bas starp visām trim grupām paraugu lieces laikā netika konstatētas $(p>0,05)$ : graujošā sprieguma lielums placebo k̦irurgijas grupas paraugiem bija 176,7 (216-154) MPa, HAP/TCP grupas paraugiem 194,6 (207,2-169,9) $\mathrm{MPa}$ un $\mathrm{HAP} / \mathrm{TCP} / 5 \% \mathrm{Sr}$ grupas paraugiem 193,7 (208,1-176,1) MPa (3.3. att.).

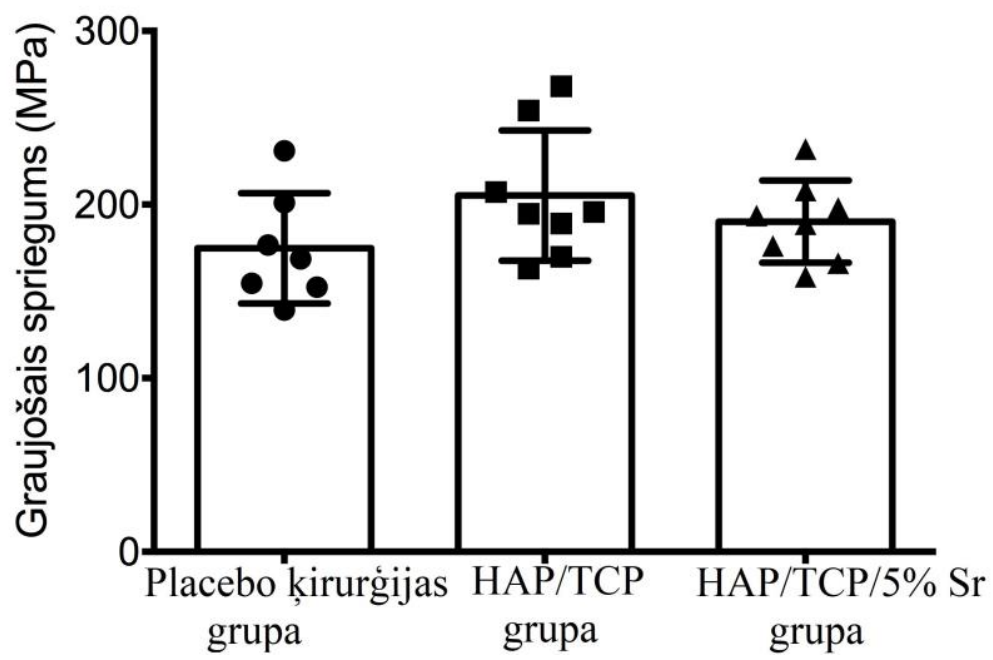

3.3. att. Operēta augšstilba paraugu graujošais spriegums dažādām grupām 
Neoperēta augšstilba placebo ķirurğijas grupas paraugiem graujošais spriegums bija 155,5 (174,7-140,8) MPa, kas ir statistiski ticami mazāk nekā HAP/TCP grupas paraugiem 209,2 $(234,2-164,4) \mathrm{MPa}, \mathrm{p}=0,017$, un $\mathrm{HAP} / \mathrm{TCP} / 5 \% \mathrm{Sr}$ grupas paraugiem 177,7 $(200,3-165,5) \mathrm{MPa}, \mathrm{p}=0,026$. Statistiski ticamas graujošā sprieguma atškiirības starp HAP/TCP un HAP/TCP/5 \% Sr grupas paraugiem netika atrastas, $\mathrm{p}=0,46$ (3.4. att.).

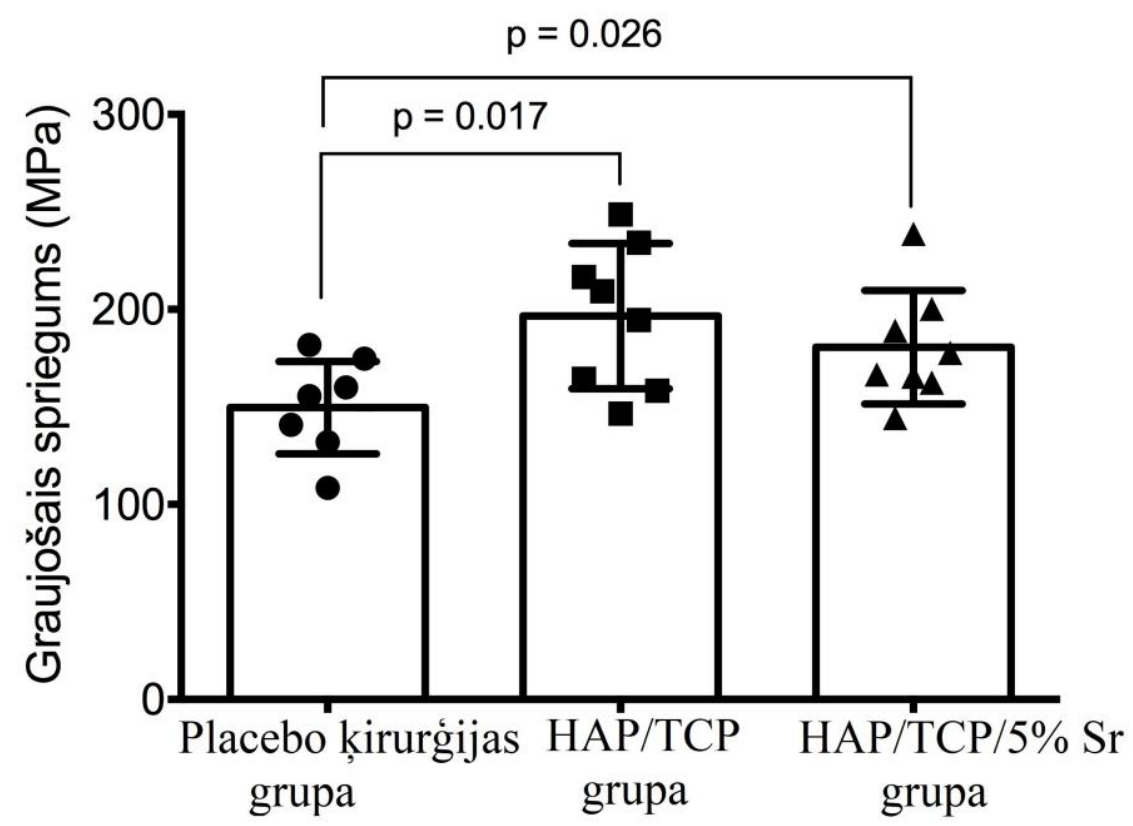

3.4. att. Neoperēta augšstilba paraugu graujošais spriegums dažādām grupām

\subsubsection{Lieces moduḷa noteikšanas un datu statistiskās apstrādes rezultāti}

Lieces modulis raksturo materiāla stingumu: jo lielāks ir lieces modulis, jo materiāls ir stingāks. Pētījuma rezultāti pierādīja, ka operēta augšstilba placebo ḳirurǵijas grupas paraugu lieces modulis bija 16,31 (18,66-12,15) GPa, kas ir statistiski ticami mazāk nekā HAP/TCP grupas paraugiem 19,87 (21,10-17,94) GPa, $\mathrm{p}=0,01$, un HAP/TCP/5 \% Sr grupas paraugiem 21,88 (27,53-21,09) GPa, $\mathrm{p}=0,005$. Tika atrastas statistiski ticamas lieces moduḷa atškirības starp HAP/TCP un HAP/TCP/5 \% Sr grupas paraugiem: HAP/TCP grupas kaulu paraugu lieces modulis ir mazāks nekā HAP/TCP/5 \% Sr grupas kaulu paraugu lieces modulis, $\mathrm{p}=0,02$ (3.5. att.). 


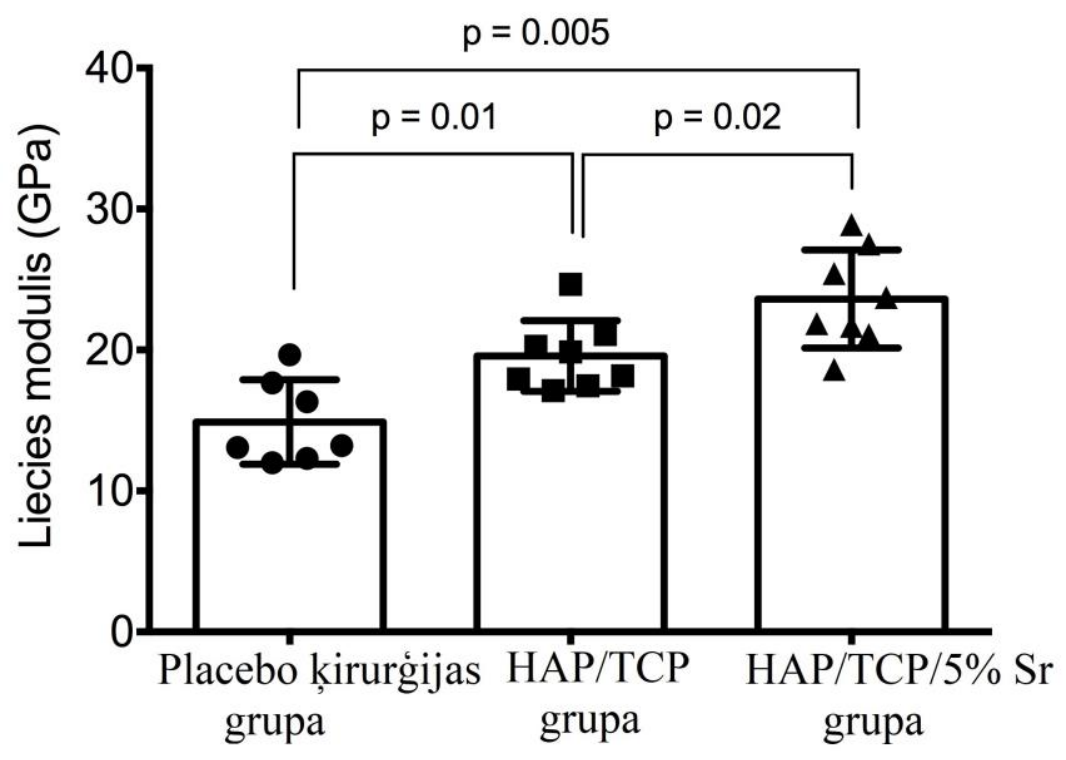

3.5. att. Operēta augšstilba paraugu lieces modulis dažādām grupām

Neoperēta augšstilba placebo k̦irurğijas grupas paraugu lieces modulis bija 14,91 $(17,36-13,6) \mathrm{GPa}$, kas ir statistiski ticami mazāk nekā HAP/TCP grupas paraugiem 21,86 $(25,81-19,6) \mathrm{GPa}, \mathrm{p}=0,004$, un HAP/TCP/5 \% Sr grupas paraugiem 22,11 (23,41-20,29) GPa, $\mathrm{p}=0,006$. Statistiski ticamas lieces moduḷa atšķirības starp HAP/TCP un HAP/TCP/5\% Sr grupas paraugiem netika atrastas, $\mathrm{p}=0,87$ (3.6. att.).

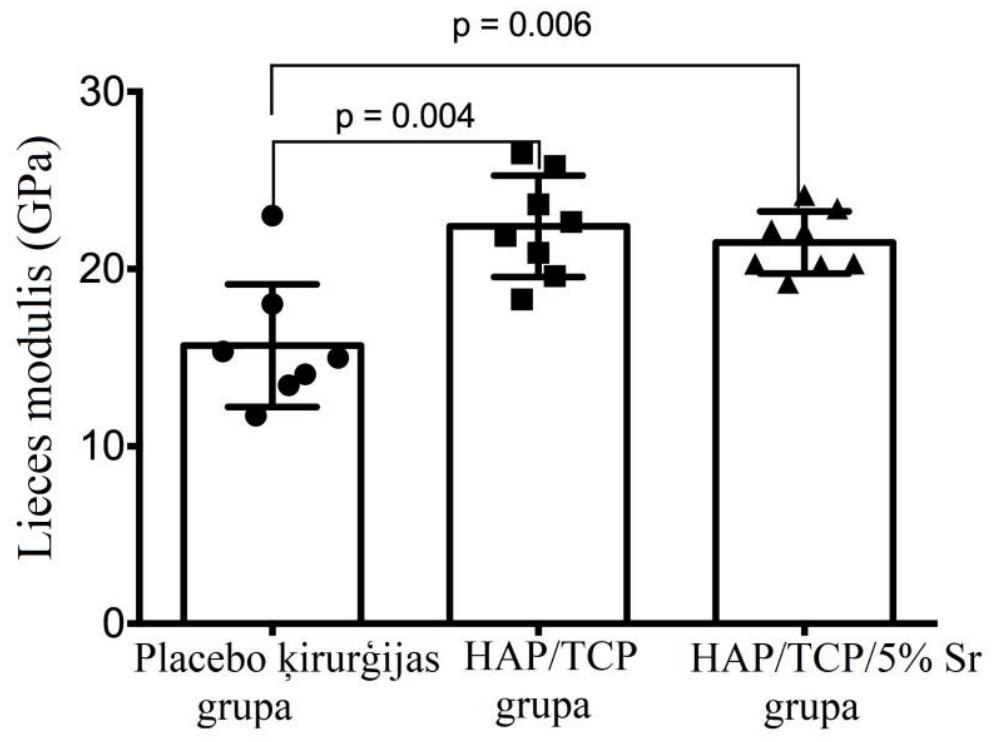

3.6. att. Neoperēta augšstilba paraugu lieces modulis dažādām grupām 


\subsection{Biomehāniskā pētījuma un datu statistiskās apstrādes rezultāti apakšžokḷa kaula paraugos}

Visi kaula paraugi, kuri tika izmantoti apakšžokḷa kaulu biomehānisko parametru noteikšanai, tika iedalīja trīs grupās:

1) placebo ķirurgijijas grupa: labajā augšstilbā trochanter major rajonā tika radīts defekts, bet materiāls netika ielikts;

2) HAP/TCP grupa: labajā augšstilbā trochanter major rajonā defekts tika aizpildīts ar HAP/TCP (70/30) granulām;

3) $\mathrm{HAP} / \mathrm{TCP} / 5 \% \mathrm{Sr}$ grupa: labajā augšstilbā trochanter major rajonā defekts tika aizpildīts ar HAP/TCP (70/30) granulām, kam pievienoti $5 \%$ stroncija.

\subsubsection{Graujošās deformācijas noteikšanas un datu statistiskās apstrādes rezultāti}

Placebo ķirurğijas grupas paraugiem graujošā deformācija bija 2,04 (2,37-1,76) \%, kas ir statistiski ticamāki lielāka nekā HAP/TCP grupas paraugiem 1,46 $(1,49-1,27) \%, p=0.0003$, un $\mathrm{HAP} / \mathrm{TCP} / 5 \% \mathrm{Sr}$ grupas paraugiem $1,37(1,94-1,03) \%, \mathrm{p}=0,02$. Statistiski ticamas graujošās deformācijas atšķirības starp HAP/TCP un HAP/TCP/5 \% Sr grupas paraugiem netika atrastas, $p>0,99$ (3.7. att.).

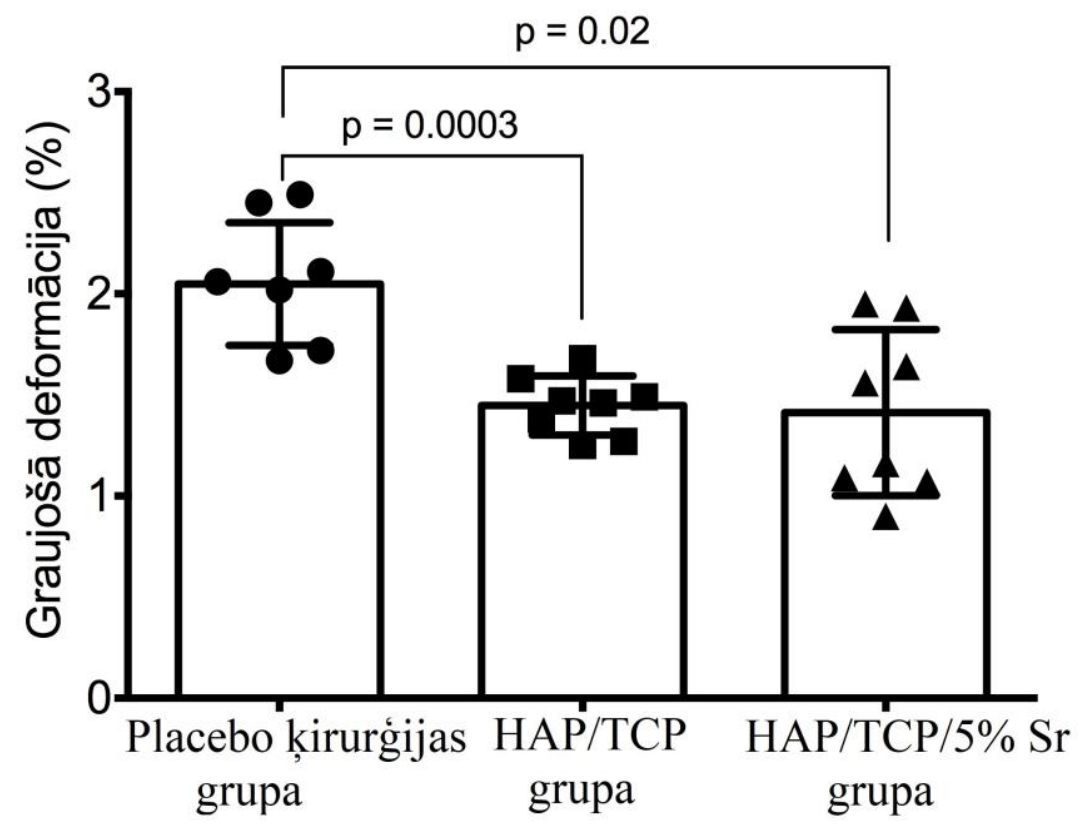

3.7. att. Apakšžokḷa kaula paraugu graujošā deformācija dažādām grupām

\subsubsection{Graujošā sprieguma noteikšanas un datu statistiskās apstrādes rezultāti}

Placebo ķirurğijas grupas paraugiem graujošais spriegums bija 89,36 $(108,6-77,44)$ MPa, kas ir statistiski ticami mazāk nekā HAP/TCP grupas paraugiem $183(202,7-155,2) \mathrm{MPa}$, 
$\mathrm{p}=0,0003$, un HAP/TCP/5\% Sr grupas paraugiem 241,9 (250,9-234,9) MPa, p = 0,0007. Tika atrastas statistiski ticamas graujošā sprieguma atšķirības starp HAP/TCP un HAP/TCP/5 \% Sr grupām: HAP/TCP grupas kaulu paraugu graujošais spriegums ir mazāks nekā HAP/TCP/5 \% Sr grupas kaulu paraugu graujošais spriegums, $\mathrm{p}=0,022$ (3.8. att.).

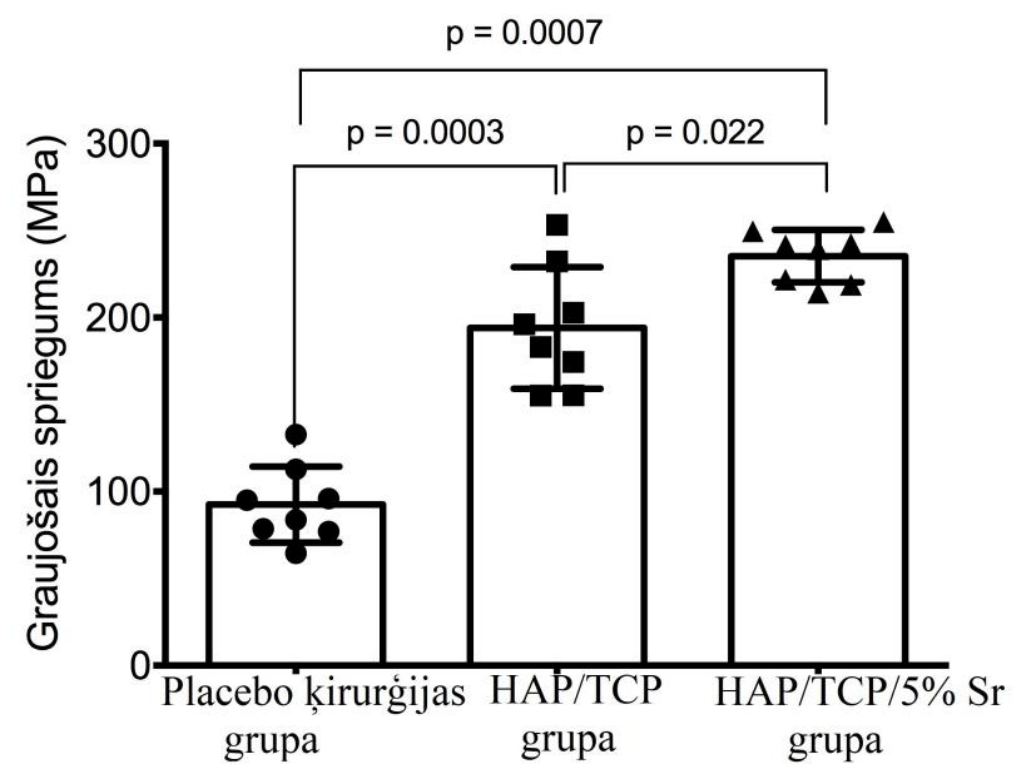

3.8. att. Apakšžokḷa kaula paraugu graujošais spriegums dažādām grupām

\subsubsection{Lieces moduḷa noteikšanas un datu statistiskās apstrādes rezultāti}

Placebo ķirurğijas grupas paraugu lieces modulis bija 5,25 (7,23-4,35) GPa, kas ir statistiski ticami mazāk nekā HAP/TCP grupas paraugiem 12,44 (17,71-11,55) GPa, p = 0,0003, un HAP/TCP/5 \% Sr grupas paraugiem 15,83 (20,8-14.67) GPa, p = 0,0007. Statistiski ticamas lieces moduḷa atšķirības starp HAP/TCP un HAP/TCP/5 \% Sr grupas paraugiem netika atrastas, $\mathrm{p}=0,29$ (3.9. att.).

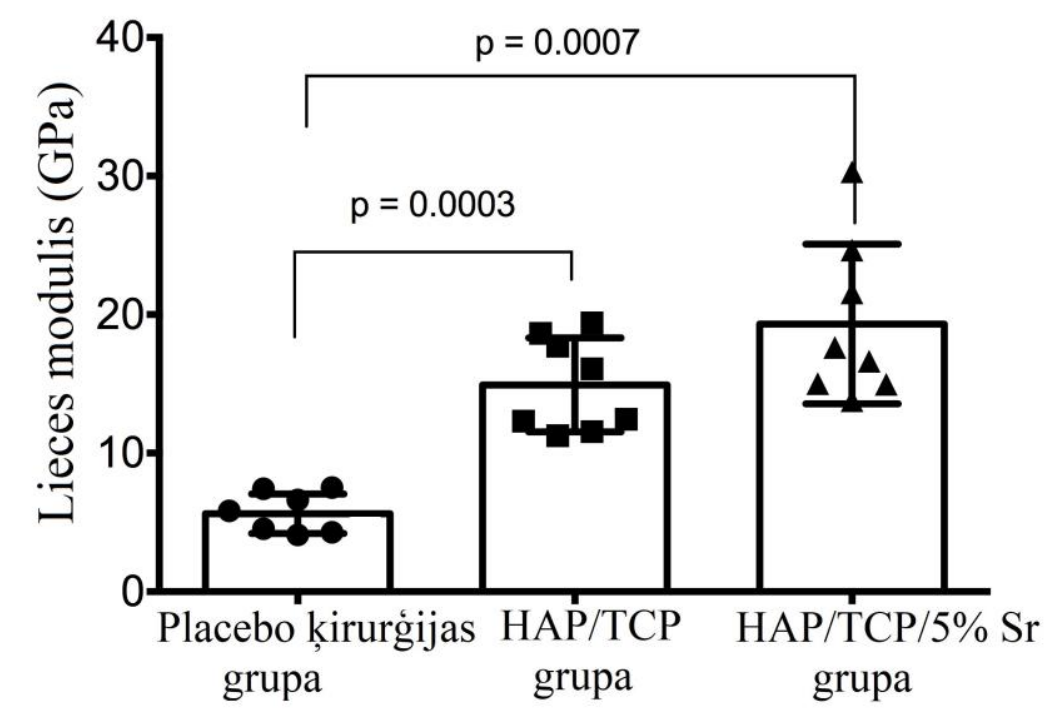

3.9. att. Apakšžokḷa kaula paraugu lieces modulis dažādām grupām 


\subsection{Rentgenoloğiskā pētījuma un datu statistiskās apstrādes rezultāti augšstilba kaula paraugos}

Visi kaula paraugi, kuri tika izmantoti augšstilba kaulu minerālblīvuma noteikšanai, tika iedalīti trīs grupās:

1) placebo ķirurğijas grupa: labajā augšstilbā trochanter major rajonā tika uztaisīts defekts, bet materiāls netiek ielikts;

2) HAP/TCP grupa: labajā augšstilbā trochanter major rajonā defekts tika aizpildīts ar HAP/TCP (70/30) granulām;

3) $\mathrm{HAP} / \mathrm{TCP} / 5 \% \mathrm{Sr}$ grupa: labajā augšstilbā trochanter major rajonā defekts tika aizpildīts ar HAP/TCP (70/30) granulām, kam pievienoti 5 \% stroncija.

Operētā augšstilba placebo ķirurğijas grupas paraugiem kortikālā kaula blīvums bija 923 (1056-843.5) HU, kas ir statistiski ticami mazāk nekā HAP/TCP grupas paraugiem 1302 (1350-1209) HU, p = 0,016, un HAP/TCP/5 \% Sr grupas paraugiem 1344 (1459-1156) HU, $\mathrm{p}=0,042$. Statistiski ticamas kortikālā kaula blīvuma atšķirīibas starp HAP/TCP un $\mathrm{HAP} / \mathrm{TCP} / 5 \% \mathrm{Sr}$ grupas paraugiem netika atrastas, $\mathrm{p}=0,761$ (3.10. att.).

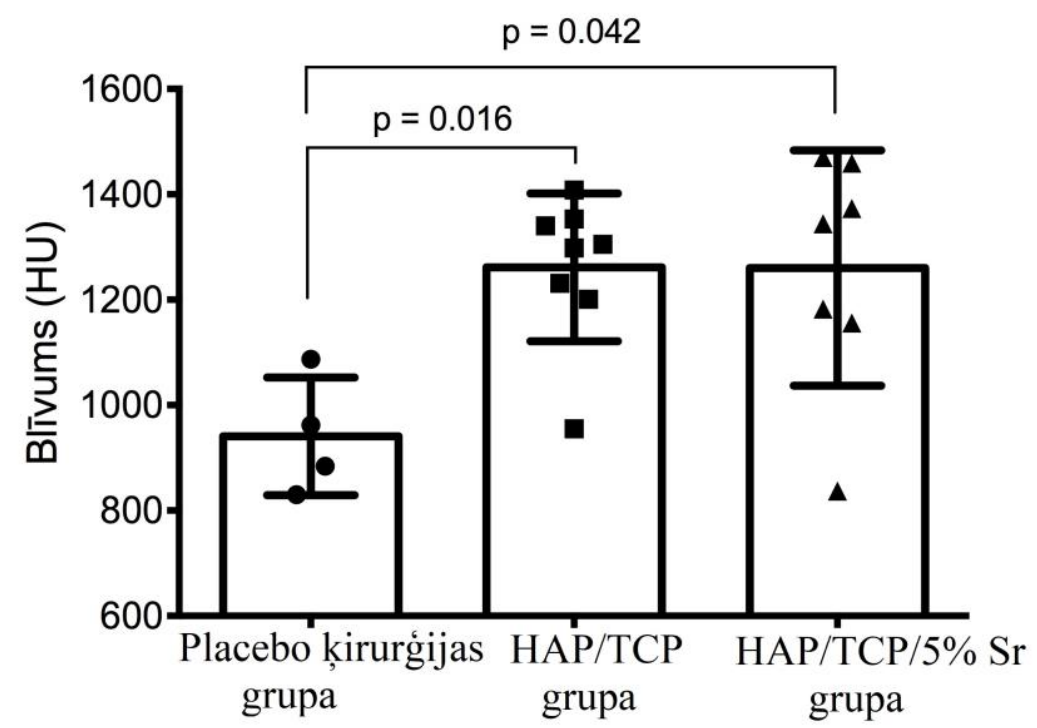

3.10. att. Operēta augšstilba paraugu kortikālā kaula blīvums dažādām grupām

Neoperēta augšstilba placebo ķirurğijas grupas paraugiem kortikālā kaula blīvums bija 935,5 (1053-876) HU, kas ir statistiski ticami mazāk nekā HAP/TCP grupas paraugiem 1212 (1360-1138) HU, p = 0,016, un HAP/TCP/5 \% Sr grupas paraugiem 1261 (1315-1090) HU, $\mathrm{p}=0,012$. Statistiski ticamas kortikālā kaula blīvuma atšķirības starp HAP/TCP un $\mathrm{HAP} / \mathrm{TCP} / 5 \% \mathrm{Sr}$ grupas paraugiem netika atrastas, $\mathrm{p}>0,99$ (3.11. att.). 


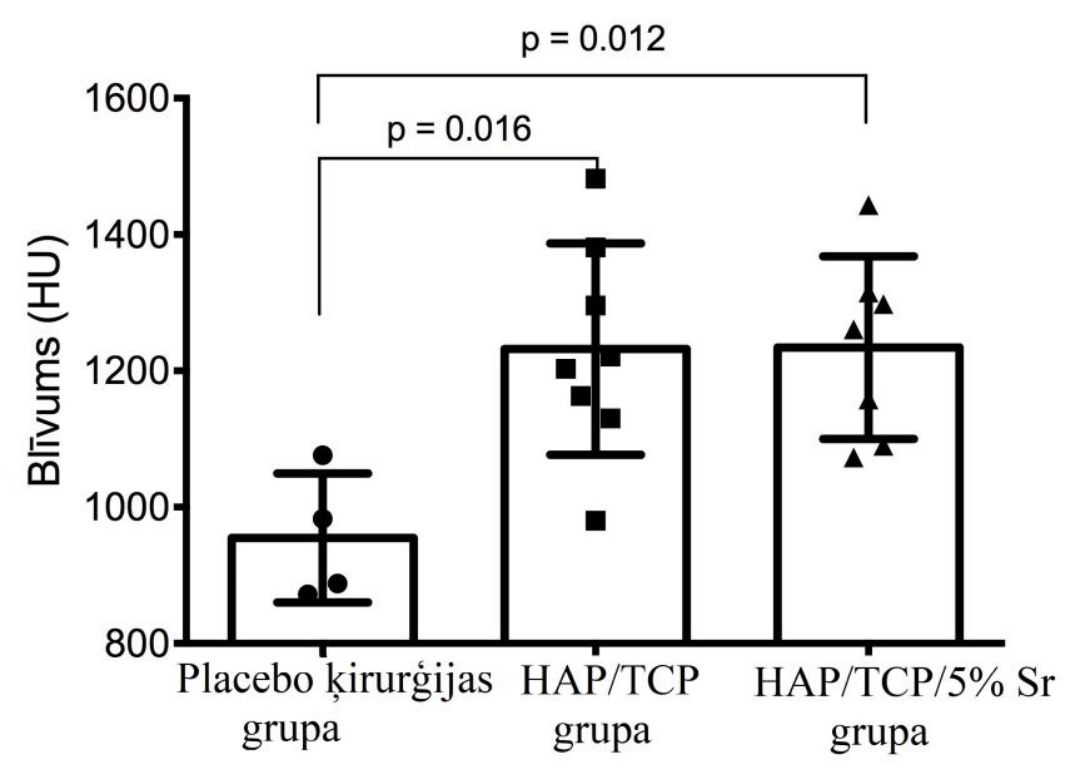

3.11. att. Neoperēta augšstilba paraugu kortikālā kaula blīvums dažādām grupām

\subsection{Rentgenoloğiskā pētījuma un datu statistiskās apstrādes rezultāti apakšžokḷa kaula paraugos}

Visi kaula paraugi, kuri tika izmantoti apakšžokḷa kaulu minerālblīvuma noteikšanai, tika iedalīti trīs grupās:

1) placebo ķirurǵijas grupa: labajā augšstilbā trochanter major rajonā tika uztaisīts defekts, bet materiāls netiek ielikts;

2) HAP/TCP grupa: labajā augšstilbā trochanter major rajonā defekts tika aizpildīts ar HAP/TCP (70/30) granulām;

3) HAP/TCP/5\% Sr grupa: labajā augšstilbā trochanter major rajonā defekts tika aizpildīts ar HAP/TCP (70/30) granulām, kam pievienoti $5 \%$ stroncija.

Placebo ķirurğijas grupas paraugiem kortikālā kaula blīvums bija 709,5 (807-645) HU, kas ir statistiski ticami mazāk nekā HAP/TCP grupas paraugiem 871 (1047-829) HU, p = 0,024, un HAP/TCP/5\% Sr grupas paraugiem 916 (962-876) HU, p = 0,006. Statistiski ticamas kortikālā kaula blīvuma atšķirības starp HAP/TCP un HAP/TCP/5\% Sr grupas paraugiem netika atrastas, $\mathrm{p}=0,522$ (3.12. att.). 


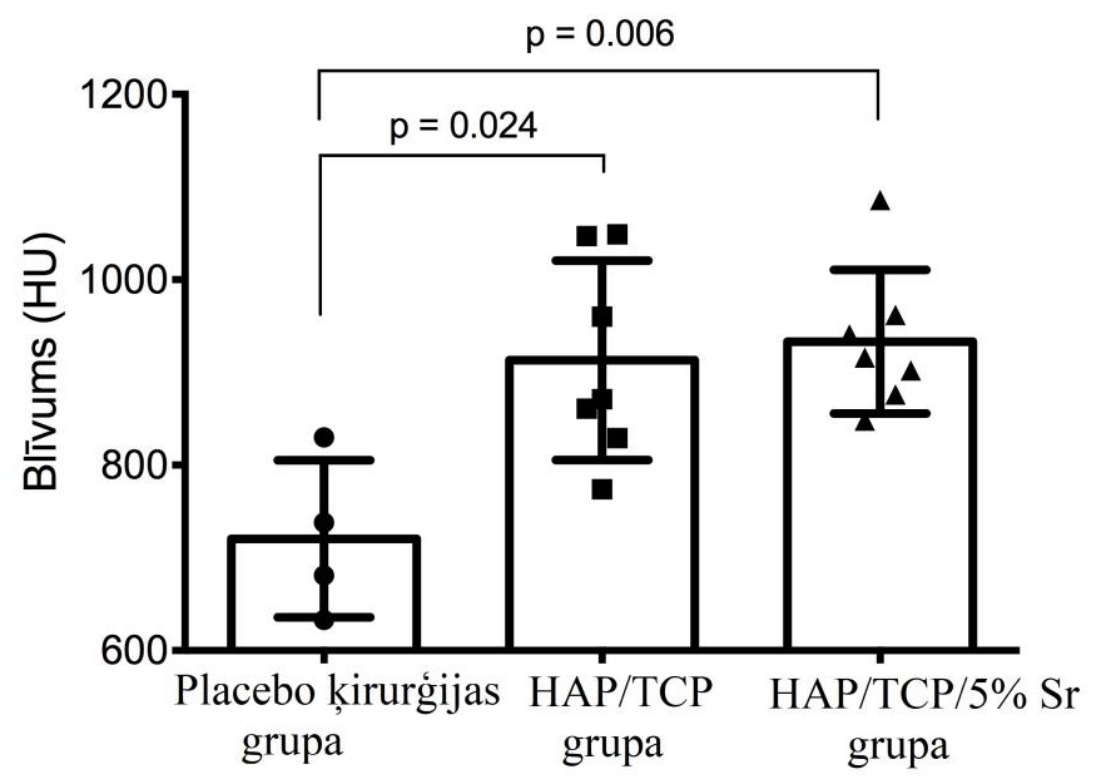

3.12. att. Apakšžokḷa kaula paraugu kortikālā kaula blīvums dažādām grupām

\subsection{Operēta un neoperēta augšstilba biomehānisko parametru un minerālblīvuma} salīdzinājums pēc dažāda biomateriāla implantācijas

Visi kaula paraugi, kuri tika izmantoti operēta un neoperēta augšstilba kaulu biomehānisko parametru un blīvuma salīdzināšanai, tika iedalīja četrās grupās:

1) HAP/TCP LA grupa: operēta augšstilba kaulu paraugi - labajā augšstilbā trochanter major rajonā defekti tika aizpildīti ar HAP/TCP (70/30) granulām;

2) HAP/TCP KA grupa: neoperēta augšstilba kaulu paraugi - labajā augšstilbā trochanter major rajonā defekts netika aizpildīts ar HAP/TCP (70/30) granulām;

3) $\mathrm{HAP} / \mathrm{TCP} / 5 \% \mathrm{Sr}$ LA grupa: operēta augšstilba kaulu paraugi - labajā augšstilbā trochanter major rajonā defekts tika aizpildīts ar HAP/TCP (70/30) granulām, kam pievienoti $5 \%$ stroncija.

4) $\mathrm{HAP} / \mathrm{TCP} / 5 \%$ Sr LA grupa: neoperēta augšstilba kaulu paraugi - labajā augšstilbā trochanter major rajonā defekts tika aizpildīts ar HAP/TCP (70/30) granulām, kam pievienoti $5 \%$ stroncija.

Salīdzinot operētu un neoperētu augšstilba kaulu paraugu graujošo deformāciju, graujošo spriegumu, elastības moduli un blīvumu netika atrastas statistiski ticamas atškirības netika atrastas $(\mathrm{p}>0,05),(3.13 .-3.16$. att.). 


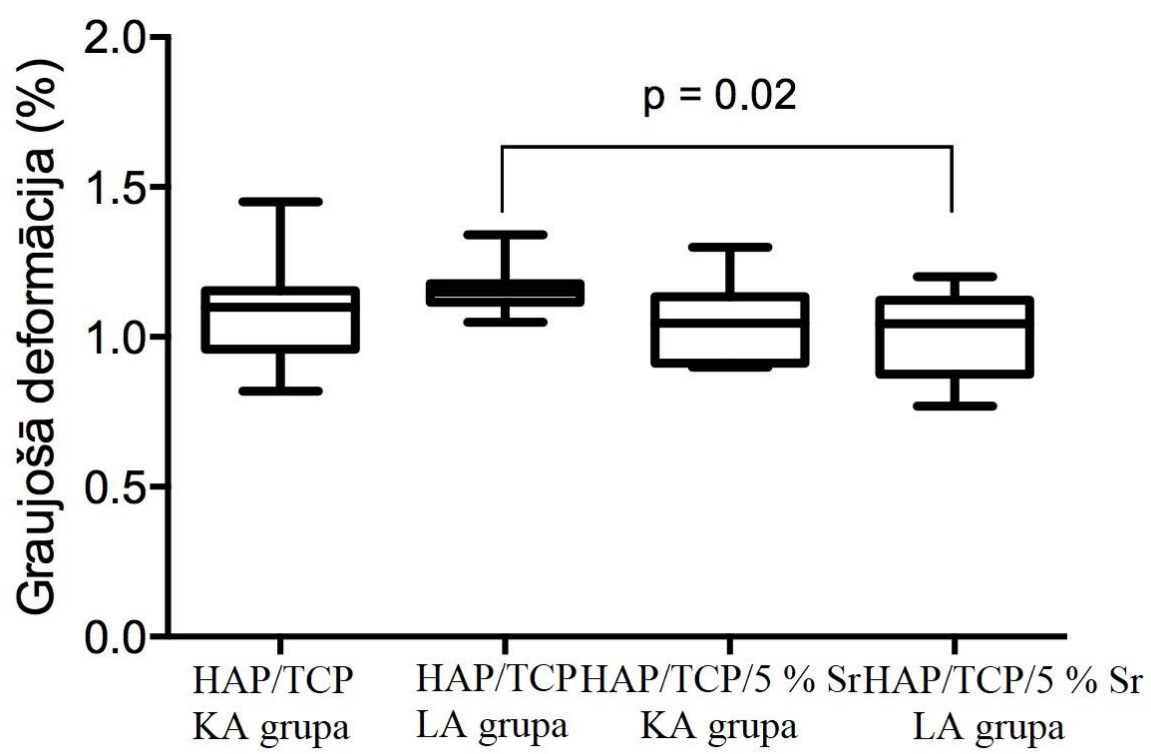

3.13. att. Operēta un neoperēta augšstilba paraugu graujošās deformācijas salīdzinājums pēc dažāda biomateriāla implantācijas

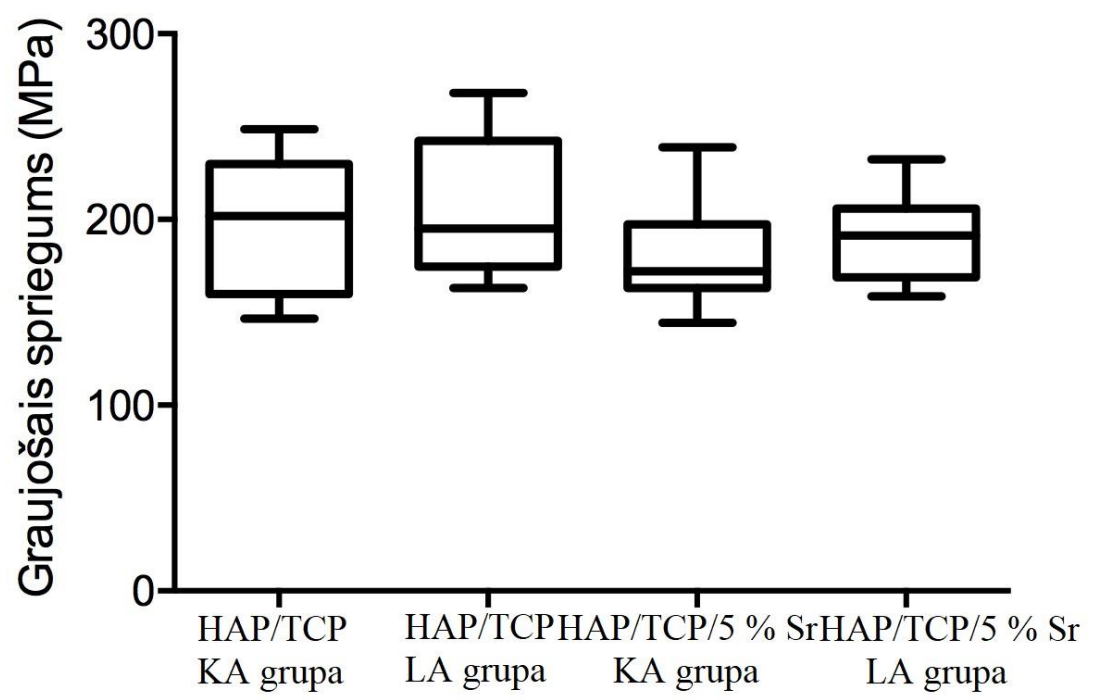

3.14. att. Operēta un neoperēta augšstilba paraugu graujošā sprieguma salīdzinājums pēc dažāda biomateriāla implantācijas 


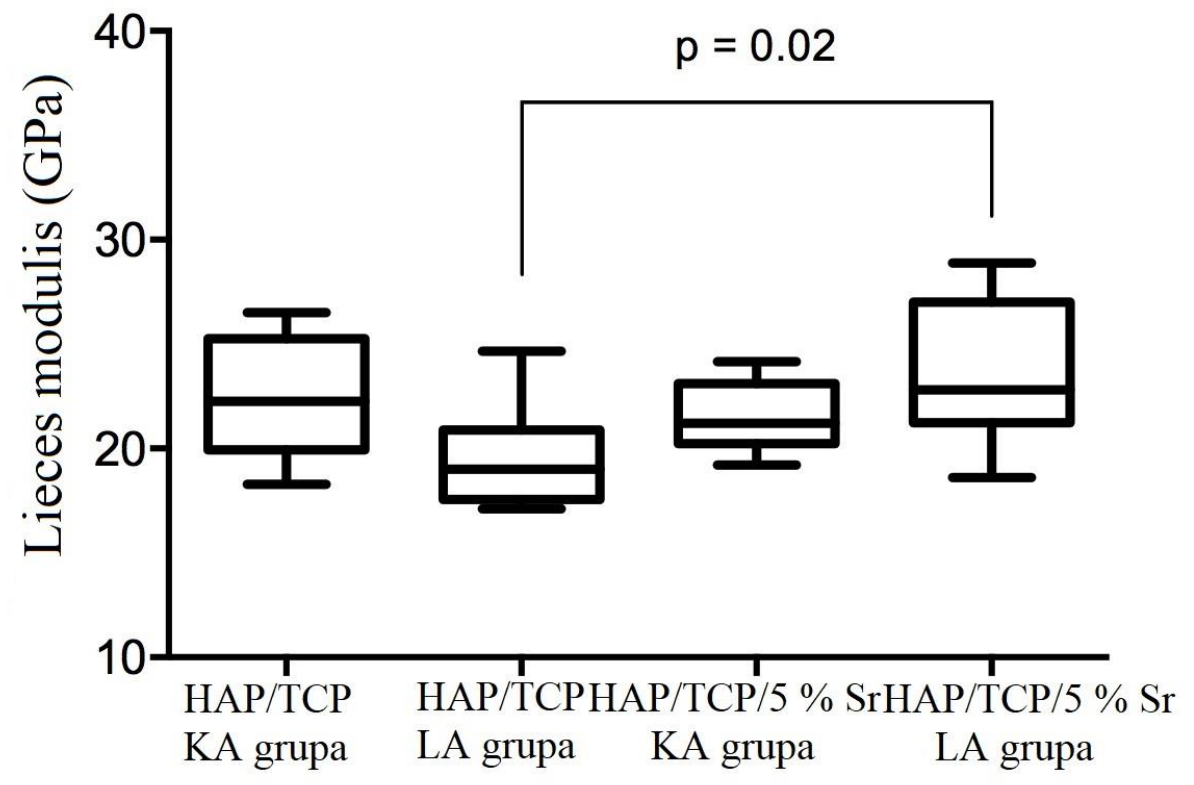

3.15. att. Operēta un neoperēta augšstilba paraugu lieces moduḷa salīdzinājums pēc dažāda biomateriāla implantācijas

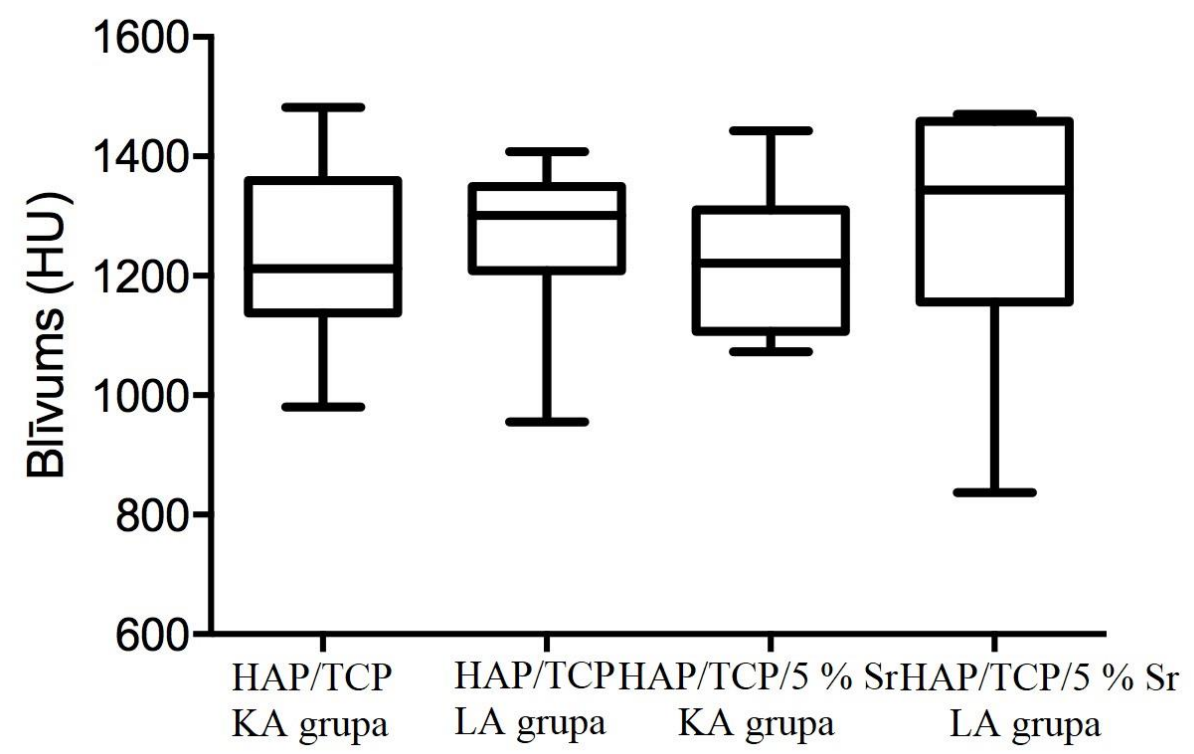

3.16. att. Operēta un neoperēta augšstilba paraugu minerālblīvuma salīdzinājums pēc dažāda biomateriāla implantācijas

\subsection{Morfoloğiskā pētījuma un datu statistiskās apstrādes rezultāti apakšžokḷa kaula} paraugos

Visi kaula paraugi, kuri tika izmantoti apakšžokḷa trabekulāra kaula laukuma noteikšanai, tika iedalīja četrās grupās:

1) kontroles grupa: veseli truši; 
2) placebo ķirurǵijas grupa: labajā augšstilbā trochanter major rajonā tika radīts defekts, bet materiāls netika ielikts;

3) HAP/TCP grupa: labajā augšstilbā trochanter major rajonā defekts tika aizpildīts ar HAP/TCP (70/30) granulām;

4) $\mathrm{HAP} / \mathrm{TCP} / 5 \% \mathrm{Sr}$ grupa: labajā augšstilbā trochanter major rajonā defekts tika aizpildīts ar HAP/TCP (70/30) granulām, kam pievienoti 5 \% stroncija.

Trabekulārā kaula laukums kontroles grupas paraugiem bija lielāks salīdzinot ar osteoporozes grupu (placebo ķirurgijas grupas, HAP/TCP grupas, HAP/TCP5\% Sr grupas) paraugiem (3.17.-3.20. att.).

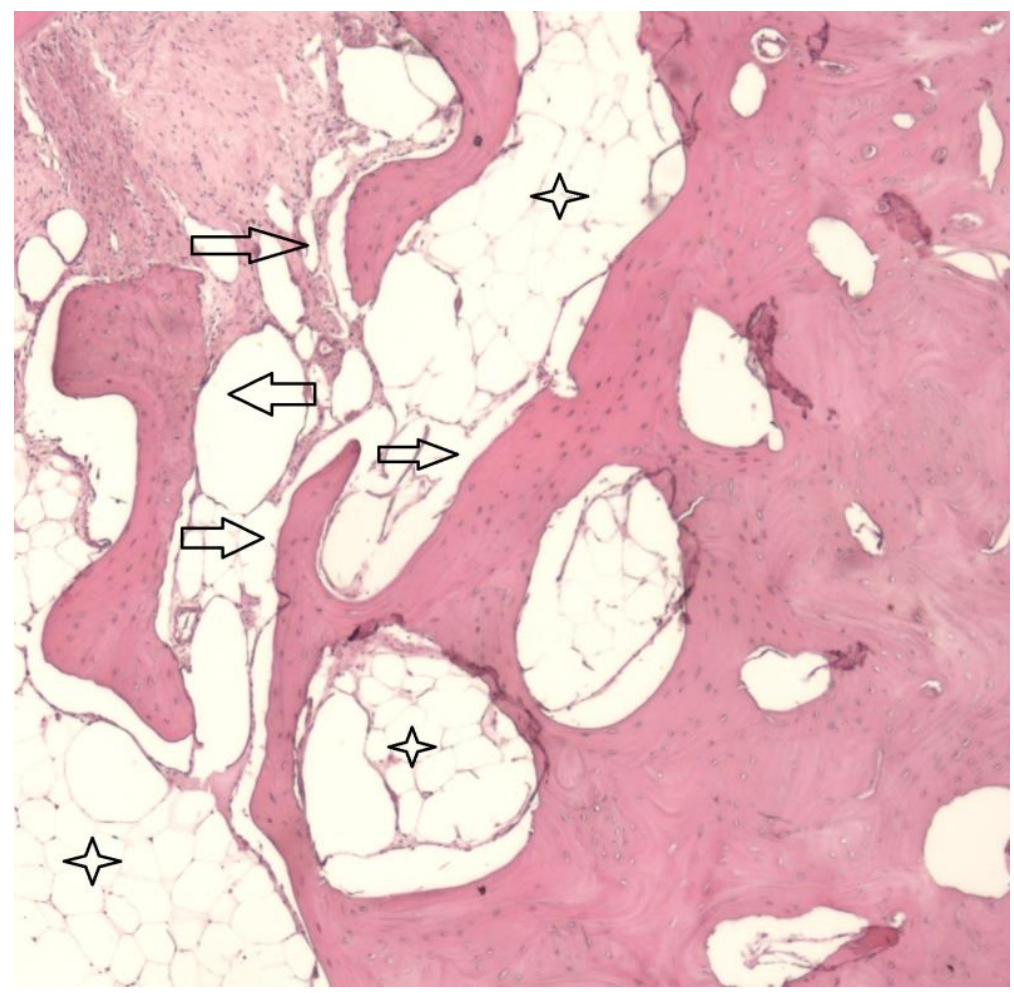

3.17. att. Vesela dz̄̄vnieka apakšžokḷa kaula premolārā rajona mikrofotogrāfija ar redzamām kaula trabekulām (bultiṇas) un taukaudiem (zvaigznītes): krasošana ar hemotoksilīnu un eozīnu, $50 \times$ palielinājumā

(fotogrāfija no darba autora personīgā arhīva) 


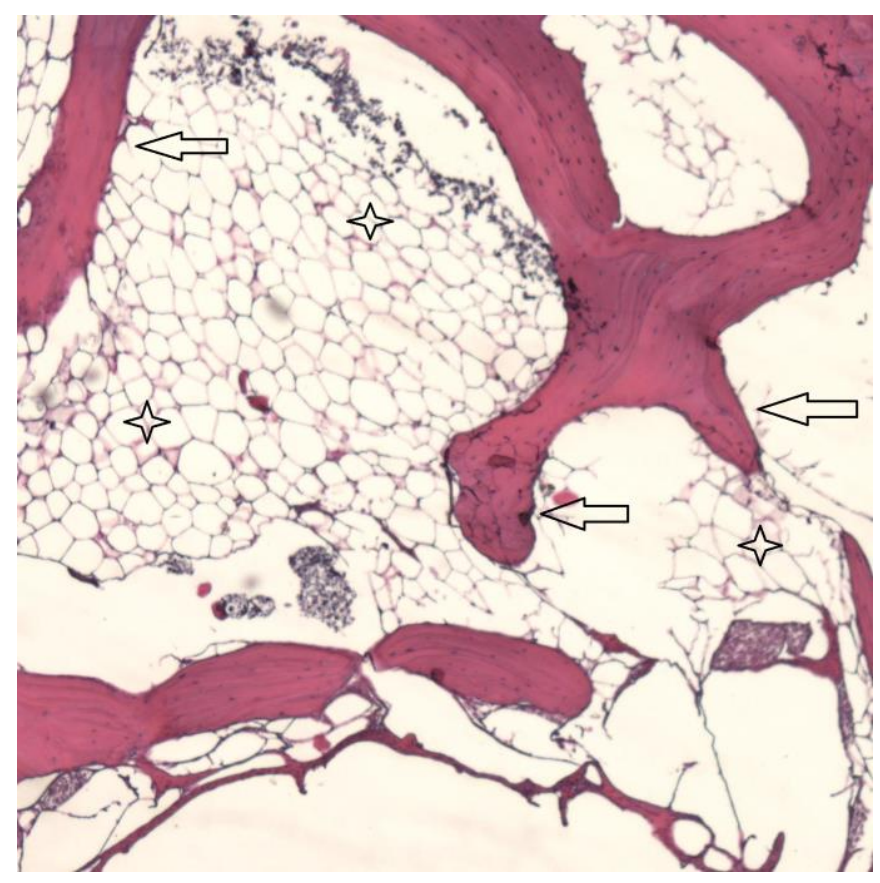

3.18. att. Osteoporotiska dzīvnieka apakšžokḷa premolārā rajona kaula zona pēc HAP/TCP granulu implantācijas ar redzamu mazāku trabekulāra kaula (bultiņas) un lielāku taukaudu (zvaigznītes) daudzumu, salīdzinot ar vesela dzīvnieka kaulu: krāsošana ar hemotoksilīnu un eozīnu, $50 \times$ palielinājumā

(fotogrāfija no darba autora personīgā arhīva)

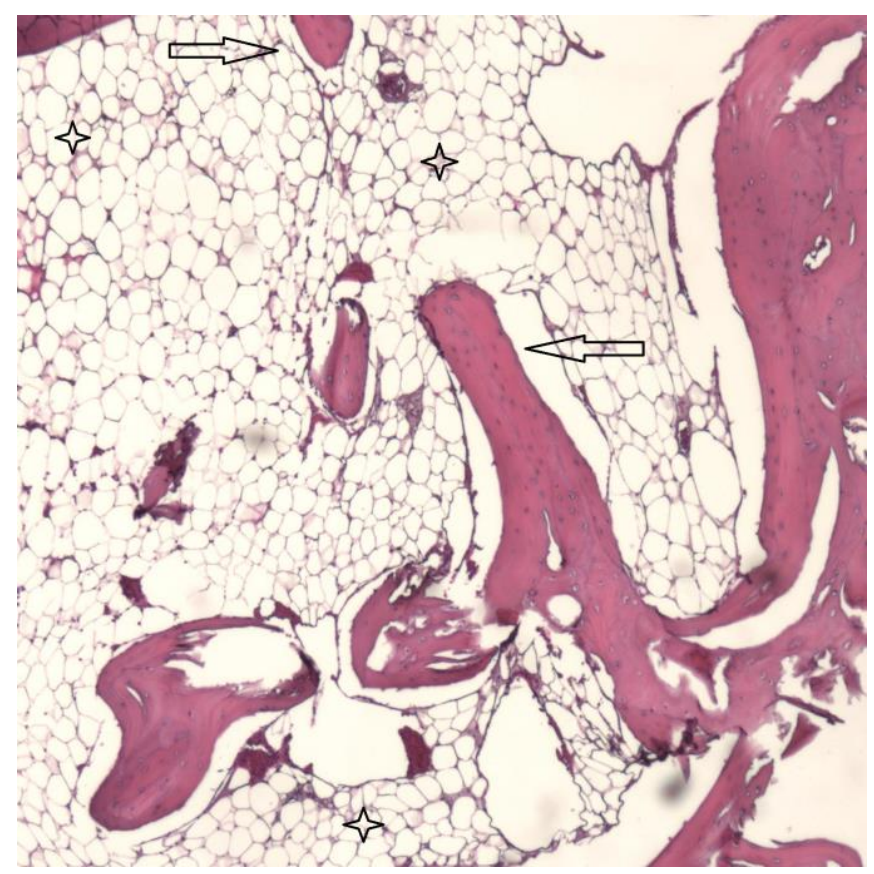

3.19. att. Osteoporotiska dzīvnieka apakšžokḷa premolārā rajona kaula zona pēc HAP/TCP ar 5 \% stronciju granulu implantācijas ar redzamu mazāku trabekulāra kaula (bultiņas) un lielāku taukaudu (zvaigznītes) daudzumu, salīdzinot ar vesela dzīvnieka kaulu: krāsošana ar hemotoksilīnu un eozīnu, $50 \times$ palielinājumā

(fotogrāfija no darba autora personīgā arhīva) 


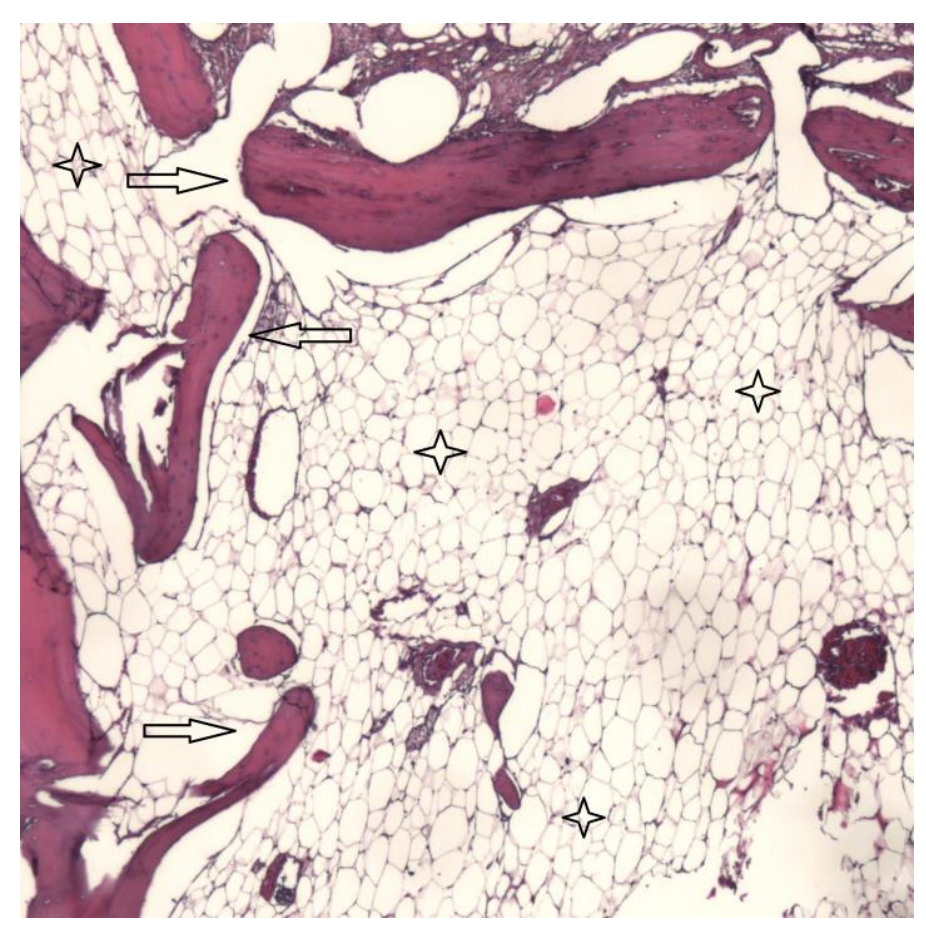

3.20. att. Osteoporotiska dz̄ivnieka apakšžokḷa premolārā rajona kaula zona pēc placebo kirurğijas ar redzamu mazāku trabekulāra kaula (bultiņas) un lielāku taukaudu (zvaigznītes) daudzumu, salīdzinot ar vesela dzīvnieka kaulu: krāsošana ar hemotoksilīnu un eozīnu, $50 \times$ palielinājumā

(fotogrāfija no darba autora personīgā arhīva)

Trabekulārā kaula laukums kontroles grupā bija 0,20 mm² $\left(0,176-0,233 \mathrm{~mm}^{2}\right)$, kas ir statistiski ticami lielāks ( $<<0.0001)$ nekā HAP/TCP grupā $\left(0,127 \mathrm{~mm}^{2} ; 0,118-0,149 \mathrm{~mm}^{2}\right)$, HAP/TCP/5 \% Sr grupā $\left(0,136 \mathrm{~mm}^{2} ; 0,108-0,166 \mathrm{~mm}^{2}\right)$ un placebo ķirurğijas grupā $(0,135$ $\mathrm{mm}^{2} ; 0,126-0,164 \mathrm{~mm}^{2}$ ). Statistiski ticamas atšķirības starp HAP/TCP, HAP/TCP/5 \% Sr un placebo ķirurǵijas grupām netika atrastas, p>0,05 (3.21. att.).

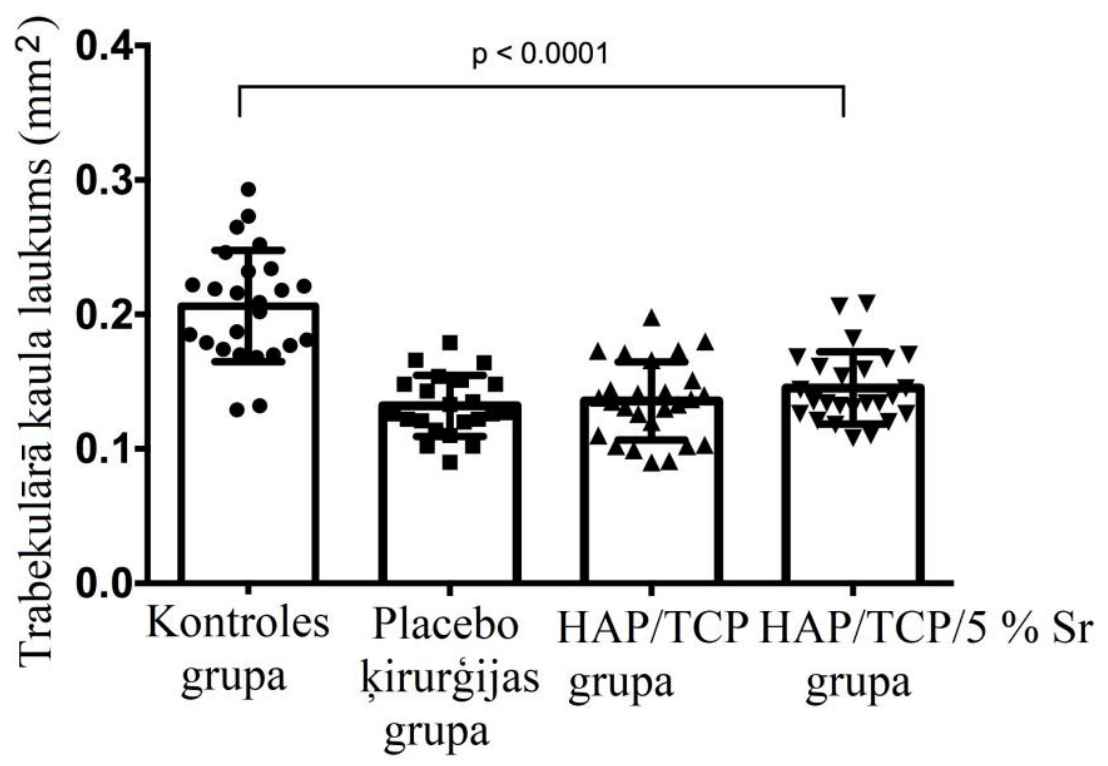

3.21. att. Trabekulārā kaula laukums dažādām grupām 


\section{Diskusija}

Darbs tika realizēts Valsts pētījumu programmas Nr. 2014.10-4/VPP-3/21 "Daudzfunkcionālie materiāli un kompozīti, fotonika un nanotehnologijas", projekts Nr. 4 "Nanomateriāli un nanotehnologiijas medicīniskajam pielietojumam", ietvaros, un tas ir liela projekta sastāvdaḷa, kura mērķis ir radīt un izpētīt jaunus, pielietojamus un konkurētspējīgus biomateriālus - nanostrukturētus kompozītmateriālus osteoporotisku kaulaudu pastiprināšanai un aizvietošanai. Pieaugot dzīves līmenim, katra valsts saskaras ar sabiedrības novecošanas problēmu risināšanu, kas saistīta ar cilvēkiem, kuru dzīves kvalitāte ir atkarīga no balsta un kustību sistēmas slimību izraisītiem kaulu funkciju traucējumiem, kas ir otrs izplatītākais cēlonis invaliditātei globālā līmenī (Sözen et al., 2017). Pēc Eiropas Savienības datiem, Latvijā apmēram $33 \%$ iedzīvotāju (t. i., 700000 cilvēku) sirgst ar balsta un kustības sistēmas slimībām, tādām kā osteoporoze, reimatoīdais artrīts, osteoartrīts, spondiloze, podagra, un vairāk nekā 200 citu slimību, kurām ir hroniska gaita un kuru dēḷ cilvēks ātri kḷūst par darba nespējīgu invalīdu.

Līdztekus osteoporozes vispārējai medikamentozai ārstēšanai pēdējā laikā notiek pētījumi par osteoporotiskā kaula pastiprināšanu lūzumu profilaksei biežākajās potenciālajās lūzumu vietās (Cosman et al., 2014; Iaquinta et al., 2019). Iaquinta et al. apskatā tika ņemti vērā dažādi audu inženierijas aspekti, kas tika izmantoti kaulu inženierijā. Tiek implantēti visvairāk izpētītie kaulaudus aizvietojošie materiāli, kas tiek modificēti, lai izstrādātu jaunas struktūras un tehnologijas. Arī mūsu pētījumā, kas tika realizēts VPP projekta ietvaros, tika paredzēts izpētìt jaunus multifunkcionālus materiālus un metodes kaulaudu apjoma un mehānisko īpašību pastiprināšanai, kaulaudu remineralizācijai un kaulaudu reosifikācijai, kaulaudu remodelāciju pavēršot vēlamajā virzienā - no atrofijas uz kaula jaunveidošanos osteoporotisku kaulu ārstēšanu un osteoporozes profilaksi, papildinot iepriekš pētītos un klīnikā pielietojamos divfāžu kalcija fosfātu biokeramikas materiālus ar stroncija joniem.

Biosaderīgu biomateriālu izstrādē nozīmīga loma ir in vivo novērojumiem, jo tikai pēc pozitīiva atzinuma par materiāla biosaderību materiāls var tikt virzīts tālākiem klīniskiem pētījumiem. Pirms in vivo pētījumiem notiek stingra piemērotāko biomateriālu atlase in vitro pētījumiem, pielietojot šūnu kultūras. Tiek izmantotas dažādas metodes dzīvnieku osteoporozes ierosināšanai, starp kurām visplašāk izplatīta ir dzīvnieku sieviešu dzimtes bilaterālā ovariektomija. Citas metodes, kuras parasti izmanto osteoporozes ierosināšanai, ir imobilizācija, diētas maiṇa un glikokortikoīdu ievadīšana (Calciolari et al., 2017). Līdzīgas osteoporozes ierosināšanas metodes ir izmantotas arī mūsu petījumā. 
Pēcmenopauzes osteoporozes imitēšanai tiek izmantoti vairāki dzīvnieku modeḷi, galvenokārt grauzēji (Kalu, 1991; Turner, 2001). Žurkas un peles parasti tiek izmantotas zemās cenas, turēšanas un pārvadāšanas ērtuma dēl, bet tās nesasniedz pilnīgu skeleta briedumu, kauliem nav Haversa kanālu sistēmas, ir mazizteikta remodelēšanās kortikālajā kaulā. Šie apstākḷi ierobežo žurku un peḷu izmantošanu osteoporozes pētījumos, īpaši kaulaudu minerālblīvumu ietekmējošu medikamentu izpētē, kas pieprasa kortikālā un trabekulārā kaula remodelēšanās dinamikas novērtēšanu. Wanderman et al. savā pētījumā secināja, ka mazāku dzīvnieku izmantošana apgrūtina implantācijas operāciju tehniskā ziņā, kā arī grūti izvērtēt osteoporozes medikamentu efektivitāti kaulaudu uzbūves īpatnību dēḷ (Wanderman et al., 2018). Savukārt Kimmel pētījuma dati liecina, ka lielāku dzīvnieku (piem., suņu, aitu, pērtiķu) izmantošana eksperimentālajās operācijās tehnoloǵiskā ziṇā tās vairāk tuvinātu cilvēku operācijām, bet tās nav iespējams tehnisku iemeslu dēḷ un piešḳirtā finansējuma ietvaros (Kimmel, 2001). Castaneda et al. biomateriālu pētījumos rekomendē izmantot trušus, jo viniiem ir aktīva kaulaudu remodelēšanās. Trušu un cilvēku audos novērojamās morfologiskās pārmaiņas ir līdzīgas un salīdzināmas. Truši ir labs modelis eksperimentālas osteoporozes pētījumiem, jo sasniedz skeleta briedumu 7-8 mēnešos un tiem ir ievērojama remodelēšanās kortikālajā kaulā (Castaneda et al., 2008). Mūsu eksperimentālajā pētījumā kā dzīvnieku modelis tika izmantoti truši.

Analizējot literatūras avotus, netika atrasts neviens pētījums, kurā tikuši salīdzināti kaulaudu biomehāniskie parametri vai minerālblīvums blakus biomateriāla implantācijas vietai un attālināti no tās, kā osteoporozes modeli izmantojot dz̄ivniekus. Turklāt bieži vien tajos analizēti kaulu paraugi no divām vai trim dzīvnieku grupām. Mūsu pētījumu var uzskatīt par unikālu, jo tika analizēti 102 kaulaudu paraugi no 13 dažādām dzīvnieku grupām, salīdzinot kaulaudu paraugus pēc divfāžu kalcija fosfāta biokeramikas implantācijas ar vai bez stroncija klātbūtnes ar placebo ķirurǵijas un kontroles grupas kaulaudu paraugiem trušiem ar eksperimentālo osteoporozi. Tika izvērtēti biomehāniski parametri (graujošā deformācija, graujošais spriegums un elastības modulis) un minerālblīvums osteoporotisku kaulu paraugiem. Kaulu paraugi tika ņemti no operēta augšstilba ķermeņa daḷas pēc iespējas tuvāk implantācijas vietai, lai noteiktu lokālu biomateriāla ietekmi, kā arī no neoperēta augšstilba ķermeņa daḷas un apakšžokḷa kaula leṇķa rajona, lai noteiktu sistēmisku biomateriāla iedarbību.

Lai pierādītu osteoporozi, tika noteikts trabekulārā kaula laukums apakšžokḷa kaula premolārā rajonā trušiem ar eksperimentālo osteoporozi un veseliem dzīvniekiem. Tika novērotas statistiski ticamas atšķirības veseliem un osteoporotiskiem trušiem: trabekulārā kaula laukums veseliem trušiem bija $0,20 \mathrm{~mm}^{2}$, savukārt osteoporotiskiem trušiem variēja no 
$0,127 \mathrm{~mm}^{2}$ līdz $0,136 \mathrm{~mm}^{2}$, kas ir statistiski ticami mazāks, salīdzinot ar veselo trušu trabekulāro kaulu laukumu. Mūsu pētījumā netika atrastas statistiski ticamas trabekulārā kaula laukuma atškirības starp osteoporotisku dzīvnieku grupām trīs mēnešus pēc biomateriāla implantācijas un placebo ķirựgijas. Līdzịgi rezultāti ir Baier et al. pētījumā, kurā tika salīdzināts kalcija fosfăta cements ar stronciju saturošo kacija fosfăta cementu, ņemot vērā to lokālo un sistēmisko iedarbību uz kaulaudiem eksperimentālā osteoporozes dzīvnieku modelī. Savā pētījumā autors konstatēja līdzịgu kaulaudu apjomu vienu un trīs mēnešus pēc kalcija fosfātu saturoša biomateriāla implantācijas ar vai bez stroncija klātbūtnes. Taču, analizējot žurku kaulu paraugus pēc sešiem mēnešiem, lielākais trabekulārā kaula apjoms bija stronciju saturošo biomateriālu grupā (Baier et al., 2013). Tas tika apstiprināts arī Ni et al. pētījumā, kurā, izmantojot trušu modeli, stronciju saturošs hidroksiapatīta cements tika izmantots primārā gūžas locītavas protezēěanā. Autora darbā tika konstatēts, ka pēc sešiem mēnešiem stroncija klātbūtnē veidojas lielāks kaula apjoms, salīdzinot ar trušu grupu, kur kā kaulu aizvietojošais biomateriāls tika izmantots polimetilmetakrilāta cements (Ni et al., 2006). Mūsu un citu autoru iegūtie dati liecina par to, ka jaunveidoto kaulu apjoms stronciju jonu ietekmes rezultātā ir atkarīgs no laika perioda pēc implantācijas.

No dažādiem pieejamajiem kaulaudu aizvietošanas biomateriāliem tikai autologiem kaula transplantātiem piemīt osteokonduktīvas, osteoinduktīvas un osteogēnas īpašības (Sakkas et al., 2017). Tomēr šim biomateriālam piemīt neparedzamas resorbcijas īpašības, tas ir pieejams ierobežotā daudzumā, un pastāv inficēšanas risks (Nkenke et al., 2014; Jensen et al., 2016). Tādēḷ liela uzmanība tiek pievērsta biokeramisko materiālu (hidroksiapatīta) pētniecībai, šiem materiāliem jābūt ar bioloǵiskas saderība, osteovadītspējas un bionoārdīšanās īpašībām. Schlickewei et al. pētījumā izveidoti defekti veselo trušu apakšstilba kaulā tika pildīti ar HAP biokeramikas granulām. Pēc 12 nedẹ̄̂ām tika novērota kaulaudu jaunveidošanās. Dzīvnieku kaulā ieauga kaula transplantāts, un uz tā virsmas izveidojās jauns kauls (Schlickewei et al., 2015). Mūsu pētījuma darba rezultātos var novērot kaulu biomehānisku parametru uzlabojumu un minerālblīvuma palielināšanos eksperimentālo dzīvnieku grupām pēc biomateriāla implantācijas. Savukārt līdzīgais trabekulārā kaula laukums visām osteoporotisko dzīvnieku grupām liecina par nemainīgu kaula apjomu.

Divfāzu kalcija fosfāta biomateriālus var izmantot kā kaulaudu aizvietošanas materiālus, lai stiprinātu osteoporotisko kaulu un uzlabotu kaulaudu dzīšanu (Salma et al., 2013). Sulaiman et al. savā pētījumā secināja, ka $80 \%$ trikalcija fosfāta un $20 \%$ hidroksiapatīta kombinācija nodrošina mehānisku izturību un veido 60-70 \% kaulaudu. Trikalcija fosfăts kalpo kā bagāts kalcija un fosfora avots, kas var viegli asimilēties un absorbēties (Sulaiman et al., 
2013). Tas ir l̦oti bioloǵiski saderīgs, izveido resorbējošu bloḳēěanas tīklu defekta vietā, lai veicinātu sadzīšanu un nodrošinātu sākotnēju kalcija un ortofosfāta jonu izdalīšanos asinsvados, tādējādi nodrošinot jaunu kaulu veidošanos (Sulaiman et al., 2013; Salma et al., 2015). Ishakawa et al. pētījumā salīdzināja trīs komerciālus kaulaudu aizstājējus ar dažādu sastāvu: hidroksiapatītu (HAP, Neobone $\left.{ }^{\circledR}\right)$, karbonāta apatītu $\left(\mathrm{CO}_{3} \mathrm{AP}, \mathrm{Cytrans}{ }^{\circledR}\right)$ un trikalcija fosfātu (TCP, Cerasorb®). Pētījuma rezultāti parādīja, ka jauna kaula veidošana un kaula aizstājēja resorbcija ir atkarīga no biomateriāla veida. HAP gadījumā 4 nedēḷas pēc implantācijas jaunu kaulu veidošanās esošā kaula apkārtnē bija ierobežota un jauna kaula daudzums bija ḷoti mazs, 12. nedẹḷā kaulu daudzums bija gandrīz tāds pats. Atšķirībā no HAP, $\mathrm{CO}_{3} \mathrm{AP}$ gadījumā gan 4., gan 12. nedēḷā tika izveidots daudz lielāks kaulaudu daudzums. Lielāku $\mathrm{CO}_{3} \mathrm{AP}$ granulu daḷu 12. nedēḷā daḷēji nomainīja jaunizveidoti kaulaudi. Interesanti dati bija TCP gadījumā, kad 4. nedēḷā gandrīz netika novērota kaulaudu veidošanās - materiāls palika pie kaula defekta, bet 12 nedēḷas pēc biomateriāla implantācijas izveidojās liels kaulaudu daudzums un lielākā daḷa materiāla šajā laikā tika absorbēta (Ishakawa et al., 2010). Ar šo darbu autoru rezultātiem ir pamatoti mūsu pētījumā izmantoto biomateriālu izvēle: HAP biokeramikas sastāvā tika izmantots, lai jaunizveidotam kaulam nodrošinātu mehānisku izturību, savukārt TCP nodrošina jauna kaula veidošanos.

Lielākais kalcija fosfāta biomateriālu daudzums nav viendabīgs un satur mikroelementus, kuriem ir būtiska loma augšanā un kaulu atjaunošanā (Ehret et al., 2017). Stroncijs pēc bioloǵiskajām īpašībām ir līdzịgs kalcijam, tādēl uzkrājas kaulos. Agrāk stroncija ranelāts tika pielietots osteoporozes sistēmiskā ārstēšanā (piem., Protelos, Francija), bet tā biopieejamība ievērojami samazinās (par 60-70\%) atkarībā no pacienta uztura režīma. Sistēmiskajai stroncija ranelāta lietošanai ir arī vairākas nopietnas blaknes - gremošanas traucējumi, psihiskas izmainas, venoza tromboze un miokarda infarkts (Jonville-Bera et al., 2011). Hao et al. pētījums parādīja, ka stroncijs varētu uzlabot mezenhimālo cilmes šūnu osteogēno diferenciāciju un kaulu veidošanos in vivo, kā arī samazināt osteoklastu skaitu un aktivitāti (Hao et al., 2015). Tā kā stroncijs darbojas kā duāls aǵents, optimālais stroncija daudzums joprojām ir pētniecības jautājums. Kā aprakstīts literatūrā, stroncija daudzums biokeramikā ir robežās no $1 \%$ līdz $100 \%$ (Ehret et al., 2017). Saint-Jean et al. savā pētījumā pierādīja, ka zema stroncija koncentrācija biomateriālos samazina kaulu resorbciju un stimulē kaulu veidošanos (Saint-Jean et al., 2005). Līdzīgi Grynpas et al. pētījumā, žurku mugurkaula skriemeḷu tilpums palielinājās par 17\% (Grynpas et al., 1996). Arī mūsu pētîjumā biomateriāli ar nelielu stroncija daudzumu, uzlaboja kaulu biomehāniskās īpašības, salīdzinot ar pārējām osteoporotisku dzīvnvieku grupām. Savukārt, netika atrastas statistiski ticamas kaulu minerālblīvuma atškirības pēc biomateriāla implantācijas ar vai bez stroncija klātbūtnes. 
Literatūras datos ir pierādīts, ka lielākas Sr devas izraisa pretēju efektu, kavējot kaulaudu mineralizācijas procesu (Grynpas et al., 1996). Līdzīga negatīva ietekme tika novērota in vitro osteoblastos, kur lielākas $\mathrm{Sr}$ devas $(>20 \mu \mathrm{g} / \mathrm{ml})$ traucēja hidroksilapatīta veidošanos, samazinot kaulaudu mineralizāciju (Verbercmoes et al., 2003). Tādēl, lai labāk izprastu to lomu, osteoporotisko kaulaudu atjaunošanās mehānismos nepieciešami turpmāki pētîjumi ar dažādu stroncija daudzumu biomateriālā.

Pētot Rīgas Tehniskās universitātes Rūdolfa Cimdiṇa Rīgas Biomateriālu inovāciju un attīstības centra divfāžu kalcija fosfāta biokeramikas ietekmi uz kaulaudiem implantācijas vietas tuvumā (labajā augšstilbā), bija jānoskaidro, vai šim biomateriālam ir arī kaut kāda ietekme uz kaulaudiem attālinātos rajonos, piemēram, kreisajā augšstilbā. Mūsu pētījumā tika salīdzināti abu augšstilbu biomehāniskie parametri un minerālblīvums pēc biomateriāla implantācijas. Salīdzinot operētu un neoperētu augšstilba paraugu graujošo deformāciju, graujošo spriegumu, elastības moduli un minerālblīvumu, statistiski ticamas atšķirības netika atrastas $(p>0,05)$. No tā var secināt, ka pētījumā izmantoto biomateriālu ietekme uz osteoporotisko kaulu biomehāniskiem parametriem un minerālblīvumu implantācijas vietas tuvumā (labajā augšstilbā) un attālinātā rajonā (kreisajā augšstilbā) ir vienāda, kas liecina par sistēmisku biomateriāla iedarbību uz osteoporotisko trušu kaulaudiem. 


\section{Secinājumi}

1. Osteoporotisko trušu paraugu graujošā deformācija pēc biomateriāla implantācijas ir statistiski ticami mazāka, salīdzinot ar placebo ķirurǵijas grupu, kas liecina par kaulu uzlabotu spēju pretoties deformācijas spēkiem.

2. Neoperēta augšstilba un apakšžokḷa paraugu graujošais spriegums pēc biomateriāla implantācijas ir statistiski ticami lielāks, salīdzinot ar placebo ķirurğijas grupu, kas liecina par kaulu izturības palielināšanu. Savukārt operēta augšstilba paraugu grupās statistiski ticamas atšķirības netika atrastas.

3. Operēta, neoperēta augšstilba un apakšžokḷa paraugu elastības modulis pēc biomateriāla implantācijas ir statistiski ticami lielāks, salīdzinot ar placebo ķirurğijas grupu, kas liecina par kaulu stinguma īpašību palielināšanos.

4. Osteoporotisko trušu paraugu minerālblīvums pēc biomateriāla implantācijas ir statistiski ticami lielāks, salīdzinot ar placebo ķirurğijas grupu, kas liecina par sistēmisku biomateriālu iedarbību uz eksperimentālo dzīvnieku kauliem.

5. Salīdzinot operēta un neoperēta augšstilba paraugu biomehāniskos parametrus un minerālblīvumu grupām pēc biomateriālu implantācijas statistiski ticamas atšķirības netika atrastas, kas liecina par vienādu biomateriālu iedarbību uz osteoporotiskiem kauliem, kas atrodas attālināti no implantācijas vietas.

6. Stronciju saturoši biomateriāli uzlabo kaulu biomehāniskās īpašības, salīdzinot ar pārējām osteoporotisku dzīvnvieku grupām. Savukārt netika atrastas statistiski ticamas kaulu minerālblīvuma atškirīības pēc biomateriāla implantācijas ar vai bez stroncija klātbūtnes.

7. Šḳērsgriezumā trabekulārā kaula laukums veselo trušu kaulu paraugiem bija statistiski ticami lielāks nekā osteoporotiskiem trušiem, kas ir eksperimentālo dzīvnieku grupu osteoporozes pierādījums. Savukārt līdzīgais trabekulārā kaula laukums visām osteoporotisko dzīvnieku grupām liecina par nemainīgu kaula apjomu pēc biomateriāla implantācijas. 


\section{Izmantotā literatūra}

1. Afifi, A.M., Gordon, C.R., Pryor, L.S. et al. 2010. Calcium phosphate cements in skull reconstruction: a meta-analysis. Plast. Reconstr. Surg. 126(4), 1300-1309.

2. Anderson, H. C. 2003. Matrix vesicles and calcification. Curr Rheumatol Rep. 2003. 5, 222-226.

3. Asagiri, M., Takayanagi, H. 2007. The molecular understanding of osteoclast differentiation. Bone. 40, 251-264.

4. Atkins, G. J., Findlay, D. M. 2012. Osteocyte regulation of bone mineral: a little give and take. Osteoporosis international. 23, 2067-2079.

5. Augat, P., Reeb, H., Claes, L. E. 1996. Prediction of fracture load at different skeletal sites by geometric properties of the cortical shell. J. Bone Miner. Res. 11, 1356-1363.

6. Baier, M., Staudt, P., Klein, R., Sommer, U. et al. 2013. Strontium enhances osseointegration of calcium phosphate cement: a histomorphometric pilot study in ovariectomized rats. Journal of Orthopaedic Surgery and Research. 8, 16.

7. Bandeira, L., Lewiecki, E. M., Bilezikian, J. P. 2016. Pharmacodynamics and pharmacokinetics of oral salmon calcitonin in the treatment of osteoporosis. Exp. Opin. Drug Metab. Toxicol. 12, 681-689.

8. Baofeng, L., Zhi, Y., Bei, C., Guolin, M. et al. 2010. Characterization of a rabbit osteoporosis model induced by ovariectomy and glucocorticoid. Acta Orthopaedica. 81, 396-401.

9. Baron, R., Kneissel, M. 2013. WNT signaling in bone homeostasis and disease: from human mutations to treatments. Nature medicine. 19, 179-192.

10. Bassett, J. H., Williams, G.R. 2016. Role of Thyroid Hormones in Skeletal Development and Bone Maintenance. Endocr. Rev. 37, 135-187.

11. Ben-Nissan, B. 2014. Advances in calcium phosphate biomaterials.

12. Billström, G. H., Blom, A. W., Larsson, S. and Beswick, A. D. 2013. Application of scaffolds for bone regeneration strategies: Current trends and future directions. Injury. 44 (1), 28-33.

13. Bjornerem, A. 2016. The clinical contribution of cortical porosity to fragility fractures. Bonekey Rep. 5, 846.

14. Blackwell, K. A., Raisz, L. G., Pilbeam, C. C. 2010. Prostaglandins in bone: bad cop, good cop? Trends in Endocrinology \& Metabolism. 21, 294-301.

15. Blanchard, R., David, C., Thomas, L., Hardiman, R., Clement, J. G., Cooper, D. C., Pivonka, P. 2019. Structural and Material Changes of Human Cortical Bone with Age: Lessons from the Melbourne Femur Research Collection. Encyclopedia of Biomedical Engineering. 246-264.

16. Boden, S., Martin, G., Morone, M., Ugbo, J., Moskovitz, P. 1999. Posterolateral lumbar intertrnasverse process spine arthrodesis with recombinant human bone morphogenetic protein2/hydroxyapatite-tricalcium phosphate after laminectomy in the nonhuman primate. Spine. 24 , 1179-1185.

17. Bohner, M. 2000. Calcium orthophosphates in medicine: from ceramics to calcium phosphate cements. Injury, 31(4), 37-47.

18. Bonani, M., Frey, D., de Rougemont, O., Mueller, N. J., Mueller, T. F., Graf, N. et al. 2017. Infections in de novo kidney transplant recipients treated with the RANKL inhibitor denosumab. Transplantation. 101(9), 2139-2145.

19. Bonewald, L. F. 2011. The amazing osteocyte. Journal of bone and mineral research: the official journal of the American Society for Bone and Mineral Research. 26, 229-238.

20. Börjesson, A. E., Farman, H. H., Movérare-Skrtic, S., Engdahl, C., Antal, M. C., Koskela, A. et al. 2016. SERMs have substance-specific effects on bone, and these effects are mediated via ERaAF-1 in female mice. Am. J. Physiol. Endocrinol. Metab. 310, E912-E918.

21. Bouxsein, M. L., Myburgh, K. H., van der Meulen, M. C., Lindenberger, E., Marcus, R. 1994. Age-related differences in cross-sectional geometry of the forearm bones in healthy women. Calcif. Tissue Int. 54, 113-118.

22. Boyle, W. J., Simonet, W. S., Lacey, D. L. 2003. Osteoclast differentiation and activation. Nature. 15(423(6937)), 337-342.

23. Brasileiro, C. B., Chalub, L. L. F. H., Abreu, M. H. N. G. et al. 2017. Use of cone beam computed tomography in identifying postmenopausal women with osteoporosis. Arch. Osteoporos. 12, 26.

24. Brennan, M. A., Gleeson, J. P., Browne, M., O’Brien, F. J., Thurner, P. J., McNamara, L. M. 2011. Site specific increase in heterogeneity of trabecular bone tissue mineral during oestrogen deficiency. Eur. Cell Mater. 21, 396-406. 
25. Brennan, O., Kennedy, O. D., Lee, T. C., Rackard, S. M., O’Brien, F. J., McNamara, L. M. 2011. The effects of estrogen deficiency and bisphosphonate treatment on tissue mineralisation and stiffness in an ovine model of osteoporosis. J. Biomech. 44, 386-390.

26. Bruderer, M., Richards, R. G., Alini, M., Stoddart, M. J. 2014. Role and regulation of RUNX2 in osteogenesis. Eur. Cell Mater. 28, 269-286.

27. Buache, E., Velard, F., Bauden, E., Guillaume, C., Jallot, E., Nedelec, J.M., Laurent-Maquin, D., Laquerriere, P. 2012. Effect of strontium-substituted biphasic calcium phosphate on inflammatory mediators production by human monocytes. Acta Biomater. 8(8), 3113-3119.

28. Burguera, E.F., Xu, H.H.K., Weir, M.D. 2006. Injectable and rapid-setting calcium phosphate bone cement with dicalcium phosphate dihydrate. J. Biomed. Mater. Res. B Appl. Biomater. 77(1), $126-134$.

29. Busse, B., Hahn, M., Soltau, M., Zustin, J., Püschel, K., Duda, G. N. et al. 2009. Increased calcium content and inhomogeneity of mineralization render bone toughness in osteoporosis: Mineralization, morphology and biomechanics of human single trabeculae. Bone. 45, 1034-1043.

30. Calciolari, E., Donos, N., Mardas, N. 2017. Osteoporotic Animal Models of Bone Healing: Advantages and Pitfalls. J. Invest. Surg. 30, 342-350.

31. Campana, V., Milano, G., Pagano, E. et al. 2014. Bone substitutes in orthopaedic surgery: from basic science to clinical practice. J. Mater. Sci.: Mater. Med. 25, 2445-2461.

32. Carter, P. H., Schipani, E. 2006. The roles of parathyroid hormone and calcitonin in bone remodeling: prospects for novel therapeutics. Endocrine, metabolic \& immune disorders drug targets. 6, 59-76.

33. Cartwright, B., Robinson, J., Seed, P. T., Fogelman, I., Rymer, J. 2016. Hormone replacement therapy versus the combined oral contraceptive pill in premature ovarian failure: a randomized controlled trial of the effects on bone mineral density. J. Clin. Endocrinol. Metab. 101, 34973505 .

34. Castaneda, S., Calvo, E., Largo, R., Gonzalez-Gonzalez, R., de la Piedra, C., Diaz-Curiel, M., Herrero-Beaumont, G. 2008. Characterization of a new experimental model of osteoporosis in rabbits. J. Bone Miner. Metab. 26, 53-59.

35. Charan, J, Kantharia, N. D. 2013. How to calculate sample size in animal studies? J. Pharmacol. Pharmacother. 4, 303-306.

36. Clarke, B. 2008. Normal bone anatomy and physiology. Clin. J. Am. Soc. Nephrol. 3(3), 131139.

37. Clevers, H., Nusse, R. 2012. Wnt/beta-catenin signaling and disease. Cell. 149, 1192-1205.

38. Cohen, M. M., Jr. 2006. The new bone biology: pathologic, molecular, and clinical correlates. Am J. Med. Genet. Part A. 140A, 2646-2706.

39. Cosman, F., de Beur, S. J., LeBoff, M. S., Lewiecki, E. M., Tanner, B., Randall, S., Lindsay, R. 2014. Clinician's Guide to Prevention and Treatment of Osteoporosis. Osteoporos. Int. 25(10), 2359-2381.

40. Crabtree, N., Loveridge, N., Parker, M., Rushton, N., Power, J., Bell, K. L. et al. 2001. Intracapsular hip fracture and the region-specific loss of cortical bone: analysis by peripheral quantitative computed tomography. J. Bone Miner. Res. 16, 1318-1328.

41. Crawford, R. P., Cann, C. E., Keaveny, T. M. 2003. Finite element models predict in vitro vertebral body compressive strength better than quantitative computed tomography. Bone. 33, 744-750.

42. Cui, L., Houston, D.A., Farquharson, C., MacRae, V.E. 2016. Characterisation of matrix vesicles in skeletal and soft tissue mineralization. Bone. 87, 147-158.

43. Danciu, T. E. et al. 2003. Calcium regulates the PI3K-Akt pathway in stretched osteoblasts. FEBS Lett. 536, 193-197.

44. Das, S., Crockett, J. C. 2013. Osteoporosis - a current view of pharmacological prevention and treatment. Drugs Des. Devel. Ther. 7, 435-448.

45. De Aza, P.N., Luklinska, Z.B., Santos, C. et al. 2003. Mechanism of bone-like formation on a bioactive implant in vivo. Biomaterials. 24, 1437-1445.

46. De Grado, G. F., Keller, L., Idoux-Gillet, Y., Wagner, Q., Musset, A. M., Benkirane-Jessel, N., Bornert, F., Offner, D. 2018. Bone substitutes: a review of their characteristics, clinical use, and perspectives for large bone defects management. J. Tissue Eng. 9, 2041731418776819. 
47. Deligianni, D.D. et al. 2000. Effect of surface roughness of hydroxyapatite on human bone marrow cell adhesion, proliferation, differentiation and detachment strength. Biomaterials. 22, 87-96.

48. Delloye, C., van Cauter, M., Dufrane, D. et al. 2014. Local complications of massive bone allografts: an appraisal of their prevalence in 128 patients. Acta Orthop. Belg. 80, 196-204.

49. Dimitriou, R., Jones, E., McGonagle, D., Giannoudis, P. V. 2011. Bone regeneration: Current concepts and future directions. BMC Med. 9, 66-71.

50. Dorozhkin, S. V. 2007. Calcium orthophosphates. JMatS. 42, 1061-1995.

51. Ehret, C., Aid-Launais, R., Sagardoy, T., Siadous, R., Bareille, R., Rey, S., Pechev, S., Etienne, L., Kalisky, J., de Mones, E., Letourneur, D., Amadee Vilamitjana, J. 2017. Strontium-doped hydroxyapatite polysaccharide materials effect on ectopic bone formation. PLoS One. 12 (9), e0184663.

52. Endoskeleton of Rabbit (With Diagram). NotesOnZoology.com. Fig. 29.11 un 29.19. (http://www.notesonzoology.com/rabbit/endoskeleton/endoskele ton-of-rabbit-with-diagramvertebrates-chordata-zoology/7690).

53. Eriksen, E. F., Axelrod, D. W., Melsen, F. 1994. Bone Histomorphometry. Raven Press. 1-12.

54. Evaniew, N., Tan, V., Parasu, N. et al. 2013. Use of a calcium sulfate-calcium phosphate synthetic bone graft composite in the surgical management of primary bone tumors. Orthopedics. 36(2), e216-e222.

55. Evans, F. G. 1971. The Mechanical Properties of Bone. Charles and Thomath Publisher. 322.

56. Feng, X., McDonald, J. M. 2011. Disorders of bone remodeling. Annual review of pathology. 6, 121-145.

57. Ferguson, J.Y., Dudareva, M., Riley, N.D. et al. 2014. The use of a biodegradable antibioticloaded calcium sulphate carrier containing tobramycin for the treatment of chronic osteomyelitis: a series of 195 cases. Bone Joint J. 96-B(6), 829-836.

58. Ferrand, A., Eap, S., Richert, L. et al. 2014. Osteogenetic properties of electrospun nanofibrous PCL scaffolds equipped with chitosan-based nanoreservoirs of growth factors. Macromol. Biosci. 14(1), 45-55.

59. Föger-Samwald, U., Dovjak, P., Azizi-Semrad, U., Kerschan-Schindl, K., Pietschmann, P. 2020. Osteoporosis: Pathophysiology and therapeutic options. EXCLI J. 19, 1017-1037.

60. Garg, M. K., Kharb, S. 2013. Dual energy X-ray absorptiometry: pitfalls in measurement and interpretation of bone mineral density. Indian J. Endocrinol. Metab. 17, 203-210.

61. Goldring, S. R. 2015. The osteocyte: key player in regulating bone turnover. RMD open. 1.

62. Gouin, F., Yaouanc, F., Waast, D. et al. 2010. Open wedge high tibial osteotomies: calciumphosphate ceramic spacer versus autologous bone graft. Orthop. Traumatol. Surg. Res. 96(6), 637-645.

63. Grybauskas, S., Locs, J., Salma, I., Salms, G., Berzina-Cimdina, L. 2016. Volumetric analysis of implanted biphasic calcium phosphate/collagen composite by three-dimensional cone beam computed tomography head model superimposition. Journal of Cranio-Maxillofacial Surgery. 43(1), 167-174.

64. Grynpas, M.D., et al. 1996. Strontium increases vertebral bone volume in rats at a low dose that does not induce detectable mineralization defect. Bone. 18(3), 253-259.

65. Gustavsson, J. et al. 2012. Osteoblast-like cellular response to dynamic changes in the ionic extracellular environment produced by calcium-deficient hydroxyapatite. JMSMM. 23, 25092520.

66. Handoll, H.H.G., Watts, A.C. 2008. Bone grafts and bone substitutes for treating distal radial fractures in adults. Cochrane Database Syst. Rev. 2, CD006836.

67. Hao, J., Chou, J., Kuroda, S., Otsuka, M., Kasugai, S., Lang, N. P. 2015. Strontium hydroxyapatite in situ gel-forming system - a new approach for minimally invasive bone augmentation. Clin. Oral Implants Res. 26, 581-585.

68. Hench, L.L., Wilson, J. 1984. Surface-active biomaterials. Science. 226, 630-636.

69. Henriksen, K., Byrjalsen, I., Andersen, J. R., Bihlet, A. R., Russo, L. A., Alexandersen, P. et al. 2016. A randomized, double-blind, multicenter, placebo-controlled study to evaluate the efficacy and safety of oral salmon calcitonin in the treatment of osteoporosis in postmenopausal women taking calcium and vitamin D. Bone. 91, 122-129.

70. Hernlund, E., Svedbom, A., Ivergård, M. et al. 2013. Osteoporosis in the European Union: medical management, epidemiology and economic burden: A report prepared in collaboration 
with the International Osteoporosis Foundation (IOF) and the European Federation of Pharmaceutical Industry Associations (EFPIA). Archives of Osteoporosis. 8, 136.

71. Hiligsmann, M., Neuprez, A., Buckinx, F., Locquet, M., Reginster, J. Y. 2017. A scoping review of the public health impact of vitamin D-fortified dairy products for fracture prevention. Arch. Osteoporos. 12, 57.

72. Horak, P., Skacelova, M., Kazi, A. 2017. Role of Strontium Ranelate in the Therapy of Osteoporosis. J. Rheum. Dis. Treat. 3, 050.

73. Horch, H.-H. et al. 2006. Synthetic, pure-phase beta-tricalcium phosphate ceramic granules (Cerasorb $\left.{ }^{\circledR}\right)$ for bone regeneration in the reconstructive surgery of the jaws. IJOMS. 35, 708713.

74. Hulme, P. A., Boyd, S. K., Ferguson, S. J. 2007. Regional variation in vertebral bone morphology and its contribution to vertebral fracture strength. Bone. 41, 946-957.

75. Hussein, A. I., Morgan, E. F. 2013. The effect of intravertebral heterogeneity in microstructure on vertebral strength and failure patterns. Osteoporos. Int. 24, 979-989.

76. Iaquinta, M. R., Mazzoni, E., Manfrini, M., D’Agostino, A., Trevisiol, L., Nocini, R., Trombelli, L., Barbanti-Brodano, G., Martini, F., Tognon, M. 2019. Innovative Biomaterials for Bone Regrowth. Int. J. Mol. Sci. 20(3), 618.

77. Iolascon, G., Frizzi, L., Di Pietro, G., Capaldo, A. et al. 2014. Bone quality and bone strength: benefits of the bone-forming approach. Clinical cases in mineral and bone metabolism : the official journal of the Italian Society of Osteoporosis, Mineral Metabolism, and Skeletal Diseases. 11(1), 20-24.

78. Ishikawa, K., Matsuya, S., Lin, X., Zhang, L., Yuasa, T., Miyamoto, Y. 2010. Fabrication of low crystalline B-type carbonate apatite block from low crystalline calcite block. J. Ceram. Soc. Jpn. 118,341 .

79. Italian Society of Osteoporosis, Mineral Metabolism and Skeletal Diseases (SIOMMMS), Italian Society of Rheumatology (SIR), Varenna, M., Bertoldo, F., Di Monaco, M., Giusti, A. et al. 2013. Safety profile of drugs used in the treatment of osteoporosis: a systematical review of the literature.

80. Jaasma, M. J., Bayraktar, H. H., Niebur, G. L., Keaveny, T. M. 2002. Biomechanical effects of intraspecimen variations in tissue modulus for trabecular bone. J. Biomech. 35, 237-246.

81. Jackman, T. M., Hussein, A. I., Adams, A. M., Makhnejia, K. K., Morgan, E. F. 2014. Endplate deflection is a defining feature of vertebral fracture and is associated with properties of the underlying trabecular bone. J. Orthop. Res. 32, 880-886.

82. Jensen, A. T., Jensen, S. S., Worsaae, N. 2016. Complications related to bone augmentation procedures of localized defects in the alveolar ridge. A retrospective clinical study. Oral Maxillofac Surg. 20(2), 115-122.

83. Jeong, J., Kim, J.H., Shim, J.H, Hwang, N.S., Heo, C.Y. 2019. Bioactive calcium phosphate materials and applications in bone regeneration. Biomater. Res. 14(23), 4.

84. Jonville-Bera, A. P., Autret-Leca, E. 2011. Adverse drug reactions of strontium ranelate (Protelos(®) in France. Presse Med. 40(10), 453-462.

85. Kalbergs, V. 1971. Cilvēka anatomija. Zvaigzne. 8-12.

86. Kalu, D. N. 1991. The ovariectomized rat model of postmenopausal bone loss. Bone Miner. 15, 175-191.

87. Kanis, J. A., Cooper, C., Rizzoli, R., Reginster, J.Y. 2019. Scientific Advisory Board of the European Society for Clinical and Economic Aspects of Osteoporosis (ESCEO), the Committees of Scientific Advisors and National Societies of the International Osteoporosis Foundation (IOF). European guidance for the diagnosis and management of osteoporosis in postmenopausal women. Osteoporos Int. 30, 3-44.

88. Kanis, J. A., Johansson, H., Oden, A., Mc Closkey, E. 2011. V. Ameta-analysis of the effect of strontium ranelate on the risk of vertebral and non-vertebral fracture in postmenopausal osteoporosis and the interaction with FRAXR. Osteoporos. Int. 22, 2347-2355.

89. Kanis, J. A., Melton, L. J., 3rd, Christiansen, C., Johnston, C. C., Khaltaev, N. 1994. The diagnosis of osteoporosis. Journal of bone and mineral research: the official journal of the American Society for Bone and Mineral Research. 9, 1137-1141.

90. Kenkre, J. S., Bassett, J. 2018. The bone remodelling cycle. Ann. Clin. Biochem. 55(3), 308-327.

91. Khoshniat, S. et al. 2011. The emergence of phosphate as a specific signaling molecule in bone and other cell types in mammals. Cell Mol. Life Sci. 68, 205-218. 
92. Khosla, S., Oursler, M. J., Monroe, D. G. 2012. Estrogen and the skeleton. Trends in endocrinology and metabolism. 23, 576-581.

93. Kiernan, J. A. 2008. Histological and histochemical methods: theory and practice. Scion Pub. $12-170$.

94. Kim, D. G. 2014. Can dental cone beam computed tomography assess bone mineral density? J. Bone Metab. 21 (2), 117-126.

95. Kim, D. G., Hunt, C. A., Zauel, R., Fyhrie, D. P., Yeni, Y. N. 2007. The effect of regional variations of the trabecular bone properties on the compressive strength of human vertebral bodies. Ann. Biomed. Eng. 35, 1907-1913.

96. Kimmel, D. B. 2001. Animal models for in vivo experimentation in osteoporosis research. In: Marcus R., Feldman D., Kelsey J. (Eds.) Osteoporosis. Academic Press. 2, $29-47$.

97. Knowles, J. 2003. Phosphate based glasses for medical application. J. Mater. Chem. 13, 23952401.

98. Komm, B. S., Morgenstern, D., Yamamoto, L. A., Jenkins, S. N. 2015. The safety and tolerability profile of therapies for the prevention and treatment of osteoporosis in postmenopausal women. Exp. Rev. Clin. Pharmacol. 8, 769-784.

99. Koshino, T., Murase, T., Takagi, T. et al. 2001. New bone formation around porous hydroxyapatite wedge implanted in opening wedge high tibial osteotomy in patients with osteoarthritis. Biomaterials. 22, 1579-1582.

100. Kumar, M., Shanavas, M., Sidappa, A., Kiran, M. 2015. Cone Beam Computed Tomography Know its Secrets. J Int Oral Health. 7(2), 64-68.

101. Landis, W. J. 1995. The strength of a calcified tissue depends in part on the molecular structure and organization of its constituent mineral crystals in their organic matrix. Bone. 16, 533-544.

102. Lang, T. F., Keyak, J. H., Heitz, M. W., Augat, P., Lu, Y., Mathur, A. et al. 1997. Volumetric quantitative computed tomography of the proximal femur: precision and relation to bone strength. Bone. 21, 101-108.

103. Lanske, B., Densmore, M. J., Erben, R. G. 2014. Vitamin D endocrine system and osteocytes. Bonekey Rep. 3, 494.

104. Laurencin, C., Khan, Y., El-Amin, S.F. 2006. Bone graft substitutes. Expert Rev. Med. Devices. $3(1), 49-57$.

105. Leite, F. R. M., Ramalho, L. T. de O. 2008. Bone regeneration after demineralized bone matrix and castor oil (Ricinus communis) polyurethane implantation. J. Appl. Oral Sci. 16(2), 122-126.

106. Lejnieks A. Klīniskā medicīna 2 // Medicīnas apgads, 2012: 182 - 202.

107. Lim, J.Y. et al. 2004. Systematic variation in osteoblast adhesion and phenotype with substratum surface characteristics. J. Biomed. Mater. Res. A. 68, 504-512.

108. Lindsay, R., Krege, J. H., Marin, F., Jin, L., Stepan, J. J. 2016. Teriparatide for osteoporosis: importance of the full course. Osteoporos. Int. 27, 2395-2410.

109. Liodaki, E., Kraemer, R., Mailaender, P. et al. 2016. The use of bone graft substitute in hand surgery: a prospective observational study. Medicine. 95(24), e3631.

110. Liu, D. et al. 2008. Activation of extracellular-signal regulated kinase (ERK1/2) by fluid shear is Ca2+-and ATP-dependent in MC3T3-E1 osteoblasts. Bone. 42, 644-652.

111. Lobo, R. A., Pickar, J. H., Stevenson, J. C., Mack, W. J., Hodis, H. N. 2016. Back to the future: hormone replacement therapy as part of a prevention strategy for women at the onset of menopause. Atherosclerosis. 254, 282-290.

112. Lode, A., Heiss, C., Knapp, G., Thomas, J., Nies, B., Gelinsky, M., Schumacher, M. 2017. Strontium-Modified Premixed Calcium Phosphate Cements for the Therapy. Acta Biomater. 1, 30664-30665.

113. McNamara, L. M., Prendergast, P. J., Schaffler, M. B. 2005. Bone tissue material properties are altered during osteoporosis. J. Musculoskelet. Neuronal. Interact. 5, 342-343.

114. Mitra, R. 2011. Adverse effects of corticosteroids on bone metabolism: a review. $P M \& R$ : the journal of injury, function, and rehabilitation. 3, 466-471.

115. Mozar, A. et al. 2008. High extracellular inorganic phosphate concentration inhibits RANKRANKL signaling in osteoclast-like cells. J. Cell Physiol. 215, 47-54.

116. Na, M. K., Won, Y. D., Kim, H. C. et al. 2018. Opportunistic osteoporosis screening via the measurement of frontal skull Hounsfield units derived from brain computed tomography images. PLoS One. 13(5), e0197336. 
117. Nayak, S., Greenspan, S. L. 2016. Cost-effectiveness of osteoporosis screening strategies for men. J. Bone. Miner. Res. 31, 1189-1199.

118. Ni, G. X., Lu, W. W., Chiu, K. Y., Li, Z. Y., Fong, D. Y. T., Luk, K. D. K. 2006. Strontiumcontaining hydroxyapatite (Sr-HA) bioactive cement for primary hip replacement: an in vivo study. Journal of biomedical materials research. Part B, Applied biomaterials. 77(2), 409-415.

119. Nkenke, E., Neukam, F. W. 2014. Autogenous bone harvesting and grafting in advanced jaw resorption: morbidity, resorption and implant survival. Eur. J. Oral Implantol. 7, 203-217.

120. O’Donnell, S., Cranney, A., Wells, G. A., Adachi, J. D., Reginster, J. Y. 2006. Strontium ranelate for preventing and treating postmenopausal osteoporosis. Cochrane Database Syst. Rev. 4, CD005326.

121. Oda, K., Shibayama, Y., Abe, M., Onomura, T. 1998. Morphogenesis of vertebral deformities in involutional osteoporosis. Age-related, three-dimensional trabecular structure. Spine. 23, $1050-1055$.

122. Oden, Z. M., Selvitelli, D. M., Bouxsein, M. L. 1999. Effect of local density changes on the failure load of the proximal femur. J. Orthop. Res. 17, 661-667.

123. Offermanns, V., Andersen, O. Z., Riede, G., Sillassen, M., Jeppesen, C. S., Almtoft, K. P., Talasz, H., Öhman-Mägi, C., Lethaus, B., Tolba, R., Kloss, F., Foss, M. 2018. Effect of strontium surface-functionalized implants on early and late osseointegration: A histological, spectrometric and tomographic evaluation. Acta Biomater. 69, 385-394.

124. Offner, D., Wagner, Q., Keller, L. et al. 2017. Complications d'une autogreffe osseuse, et comparaison avec une allogreffe osseuse ou l'utilisation de BMPs (Bone Morphogenetic Proteins): une revue systématique de la littérature. Le Journal de l'Orthopédie. 18(65), 30323043.

125. Osterhoff, G., Morgan, E. F., Shefelbine, S. J., Karim, L., McNamara, L. M., Augat, P. 2016. Bone mechanical properties and changes with osteoporosis. Injury. 47(2), 11-20.

126. Pacifici, R. 1996. Estrogen, cytokines, and pathogenesis of postmenopausal osteoporosis. Journal of bone and mineral research: the official journal of the American Society for Bone and Mineral Research. 11, 1043-1051.

127. Pavone, V., Testa, G., Giardina, S. M. C., Vescio, A., Restivo, D. A., Sessa, G. 2017. Pharmacological Therapy of Osteoporosis: A Systematic Current Review of Literature. Front. Pharmacol. 8, 803.

128. Pazianas, M., Abrahamsen, B. 2016. Osteoporosis treatment: bisphosphonates reign to continue for a few more years, at least? Ann. N. Y. Acad. Sci. 1376: 5-13.

129. Polikeit, A., Nolte, L. P., Ferguson, S. J. 2004. Simulated influence of osteoporosis and disc degeneration on the load transfer in a lumbar functional spinal unit. J. Biomech. 37: 1061-1069.

130. Prodinger, P. M., Foehr, P., Bürklein, D., Bissinger, O., Pilge, H., Kreutzer, K., Eisenhart-Rothe, R., Tischer, T. 2018. Whole bone testing in small animals: systematic characterization of the mechanical properties of different rodent bones available for rat fracture models. Eur. J. Med. Res. 23, 8.

131. Qaseem, A., Forciea, M. A., McLean, R. M., Denberg, T. D. 2017. Clinical Guidelines Committee of the American College of Physicians. Treatment of low bone density or osteoporosis to prevent fractures in men and women: a clinical practice guideline update from the american college of physicians. Ann. Intern. Med. 166(11), 818-839.

132. Rahaman, M.N., Day, D.E., Bal, B.S. et al. 2011. Bioactive glass in tissue engineering. Acta Biomater. 7(6), 2355-2373.

133. Raisz, L. G. 2015. Pathogenesis of osteoporosis: concepts, conflicts, and prospects. The Journal of clinical investigation. 115: 3318-3325.

134. Ratner, B. D., Hoffman, A. S., Schoen, F. J., Lemons, J. E. 2013. Biomaterials Science: An Introduction to Materials in Medicine, 3rd Edition. Elsevier.

135. Reginster, J.Y. 2014. Cardiac concerns associated with strontium ranelate. Expert Opin Drug Saf. 13(9), 1209-1213.

136. Reid, I. R. 2013. Overview of Pathogenesis. Primer on the Metabolic Bone Diseases and Disorders of Mineral Metabolism. John Wiley \& Sons Inc. 357-360.

137. Reid, I. R. 2015. Short-term and long-term effects of osteoporosis therapies. Nat. Rev. Endocrinol., 2015; 11(7): 418-28. 
138. Riddle, R.C. et al. 2006. MAP kinase and calcium signaling mediate fluid flowinduced human mesenchymal stem cell proliferation. American journal of physiology-cell. Physiology. 290: C776-C784.

139. Roberts, T.T., Rosenbaum, A.J. 2012. Bone grafts, bone substitutes and orthobiologics: the bridge between basic science and clinical advancements in fracture healing. Organogenesis. 8(4), 114-124.

140. Roodman, G. D. 1999. Cell biology of osteoclast. Experimental hematology. 27 (8), 1229-1241.

141. Ross, R. 1993. The pathogenesis of atherosclerosis: a perspective for the 1990s. Nature. 362(6423), 801-809.

142. Saikia, K.C., Bhattacharya, T.D., Bhuyan, S.K. et al. 2008. Calcium phosphate ceramics as bone graft substitutes in filling bone tumor defects. Indian J. Orthop. 42(2), 169-172.

143. Saint-Jean, S. J., Camire, C. L., Nevsten, P., Hansen, S., Ginebra, M. P. 2005. Study of the reactivity and in vitro bioactivity of Sr-substituted alpha-TCP cement. J. Mater. Sci. Mater. Med. 16, 993-1001.

144. Sakkas, A., Wilde, F., Heufelder, M., Winter, K., Schramm, A. 2017. Autogenous bone grafts in oral implantology - is it still a "gold standard"? A consecutive review of 279 patients with 456 clinical procedures. Int. J. Implant Dent. 3, 23.

145. Salma, I., Petronis, S., Pilmane, M., Skagers, A., Zalite, V., Locs, J. 2015. Local recovery of Bone tissue in Osteoporotic Rabbit Hip after Implantation of HAP/TCP Bioceramic Granules. 27th European Conference on Biomaterials. 409.

146. Samavedi, S., Whittington, A.R., Goldstein, A.S. 2013. Calcium phosphate ceramics in bone tissue engineering: a review of properties and their influence on cell behavior. Acta Biomater. 9, 8037-8045.

147. Santen, R. J., Brodie, H., Simpson, E. R., Siiteri, P. K., Brodie, A. 2009. History of aromatase: Saga of an important biological mediator and therapeutic target. Endocrine Reviews. 30, $343-$ 375 .

148. Schaffler, M. B., Choi, K., Milgrom, C. 1995. Aging and matrix microdamage accumulation in human compact bone. Bone. 17, 521-525.

149. Schlickewei, C. W., Laaff, G., Andresen, A., Klatte, T. O., Rueger, J. M., Ruesing, J., Epple, M., Lehmann, W. 2015. Bone augmentation using a new injectable bone graft substitute by combining calcium phosphate and bisphosphonate as composite: An animal model. J. Orthop. Surg. Res. 10, 116.

150. Seeman E. 2013. Age- and menopause-related bone loss compromise cortical and trabecular microstructure. J. Gerontol. A Biol. Sci. Med. Sci. 68, 1218-1225.

151. Shin, Y. H., Shin, W. C., Kim, J. W. 2020. Effect of Osteoporosis Medication on Fracture Healing: An Evidence Based Review. J. Bone Metab. 27(1), 15-26.

152. Slutskii, L., Vetra, J. 1996. Letter to the editor: Biocompatibility and reactogenicity of materials: a semantic and logical analysis of definitions of their practical significance. Cells and Materials. 6(1-3), 137-142.

153. Smit, T. H., Burger, E. H., Huyghe, J. M. 2002. Is BMU-coupling a strain-regulated phenomenon? A finite element analysis. J. Bone Miner. Res. 15, 301-307.

154. Sözen, T., Özışık, L., Başaran, N. C. 2017. An overview and management of osteoporosis. Eur. J. Rheumatol. 4(1), 46-56.

155. Standring, S. 2015. Musculoskeletal system, Gray's Anatomy, 41th Edition. Elsevier. 135-178.

156. Sulaiman, S. B., Keong, T. K., Cheng, C. H., Saim, A. B., Idrus, R. B. H. 2013. Tricalcium phosphate/hydroxyapatite (TCP-HA) bone scaffold as potential candidate for the formation of tissue engineered bone. Indian J. Med. Res. 137(6), 1093-1101.

157. Suzuki, T., Nakamura, Y., Kato, H. 2017. Changes of bone-related minerals during denosumab administration in post-menopausal osteoporotic patients. Nutrients. 9(8), E871.

158. Tabatabaei-Malazy, O., Salari, P., Khashayar, P., Larijani, B. 2017. New horizons in treatment of osteoporosis. Daru. 25, 2.

159. Taichman, R. S. 2005. Blood and bone: Two tissues whose fates are intertwined to create the hematopoietic stem cell niche. Blood. 105, 2631-2639.

160. Takeuchi, T., Tanaka, Y., Ishiguro, N., Yamanaka, H., Yoneda, T., Ohira, T. et al. 2016. Effect of denosumab on Japanese patients with rheumatoid arthritis: a dose-response study of AMG 162 (Denosumab) in patients with Rheumatoid arthritis on methotrexate to Validate inhibitory 
effect on bone Erosion (DRIVE) - a 12-month, multicentre, randomised, double-blind, placebocontrolled, phase II clinical trial. Ann. Rheum. Dis. 75, 983-990.

161. Teitelbaum, S. L. 2003. Osteoclasts: What do they do and how do they do it? The American Journal of Pathology. 170(2), 427-435.

162. Tenti, S., Cheleschi, S., Guidelli, G.M., Galeazzi, M., Fioravanti, A. 2014 What about strontium ranelate in osteoarthritis? Doubts and securities. Mod Rheumatol. 24(6): 881-884.

163. Thomsen, J. S., Ebbesen, E. N., Mosekilde, L. 2002. Zone-dependent changes in human vertebral trabecular bone: clinical implications. Bone. 30, 664-669.

164. Tilkeridis, K., Touzopoulos, P., Ververidis, A. et al. 2014. Use of demineralized bone matrix in spinal fusion. World J. Orthop. 5(1), 30-37.

165. Tong, X., Burton, I. S., Isaksson, H., Jurvelin, J. S., Kroger, H. 2015. Cortical bone histomorphometry in male femoral neck: the investigation of age-association and regional differences. Calcif. Tissue Int. 94(4), 295-306.

166. Turner, A. S. 2001. Animal models of osteoporosis: necessity and limitations. Eur. Cell Mater. $1,66-81$.

167. Vaananen, H. K. 2000. The cell biology of osteoclast function. J. Cell Sci. 113, 377-381.

168. Vanderschueren, D., Gaytant, J., Boonen, S., Venken, K. 2008. Androgens and bone. Current opinion in endocrinology, diabetes, and obesity. 15, 250-254.

169. Verberckmoes, S.C., De Broe, M.E., D’Haese, P.C. 2003. Dose-dependent effects of strontium on osteoblast function and mineralization. Kidney Int. 64(2), 534- 43.

170. Wachter, N. J., Krischak, G.D., Mentzel, M., Sarkar, M. R., Ebinger, T., Kinzl, L. et al. 2002. Correlation of bone mineral density with strength and microstructural parameters of cortical bone in vitro. Bone. 31, 90-95.

171. Wanderman, N. R., Mallet, C., Giambini, H., Bao, N., Zhao, C., Kai-Nan, A., Freedman, B. A., Nassr, A. 2018. An Ovariectomy-Induced Rabbit Osteoporotic Model: A New Perspective. Asian Spine J. 12(1), 12-17.

172. Wang, W., Yeung, K. W. K. 2017. Bone grafts and biomaterials substitutes for bone defect repair: A review. Bioact. Mater. 2, 224-247.

173. Wang, X., Bank, R. A., TeKoppele, J. M., Agrawal, C. M. 2001. The role of collagen in determining bone mechanical properties. J. Orthop. Res. 19, 1021-1026.

174. Weiner, S., Sagi, I., Addadi, L. 2005. Structural biology: Choosing the crystallization path less traveled. Science. 309, 1027-1028.

175. Yamada, H. 1970. Strength of Biological Materials. The Williams and Wilkins Company. 297.

176. Yang, L. P., Dong, Y. P., Luo, W. P., Zhu, T., Li, Q. T., Zhang, L. J., Kong, J., Yuan, Z. W., Zhao, Q. 2018. Calbindin-D28K mediates 25(OH)D3/VDR-regulated bone formation through MMP13 and DMP1. J. Cell Biochem. 119, 8035-8047.

177. Yeh, O. C., Keaveny, T. M. 1999. Biomechanical effects of intra-specimen variations in trabecular architecture: a three-dimensional finite element study. Bone. 25, 223-228.

178. Zarins, J., Pilmane, M., Sidhoma, E., Salma, I., Locs, J. 2017. Local and systemic morphofunctional response of osteoporotic rabbits bone defect following implantation of strontium doped biphasic ceramic granules. Solid State Phenomena. 267, 124-131.

179. Zebaze, R. M., Ghasem-Zadeh, A., Bohte, A Iuliano-Burns, S., Mirams, M., Price, R. I., Mackie, E. J., Seeman, E. 2010. Intracortical remodelling and porosity in the distal radius and postmortem femurs of women: a cross-sectional study. Lancet. 375, 1729-1736.

180. Zhou, H., Chernecky, R., Davies, J. E. 1994. Deposition of cement at reversal lines in rat femoral bone. Journal of Bone and Mineral Research. 9, 367-74. 


\section{Autora publikācijas par promocijas darba tēmu}

\section{Publikācijas starptautiski recenzējamos zinātniskos izdevumos}

1. Salms, G., Ananjevs, V., Kasyanovs, V., Skagers, A., Salma, I., Vetra, J., Zalite, V., Stipniece, L., Petronis, S. 2016. Change of Biomechanical Parameters in the Lower Jaws of Rabbits with Experimental Osteoporosis after Implantation of Calcium-Phosphate Bioceramic Material in the Greater Trochanter Region. Key Engineering Materials. 721, 224-228.

2. Ananjevs, V., Ananjeva, A., Vetra, J., Skagers, A., Salma, I., Locs, J., Kasyanov, V. 2018. Calcium Phosphate Bioceramic Material Local Influence on the Bone Biomechanical Properties at Rabbits with Experimental Osteoporosis. International Journal of Engineering \& Technology. 7, 496-497.

3. Ananjevs, V., Ananjeva, A., Vetra, J., Skagers, A., Salma, I., Neimane, L., Kasyanov, V. 2019. General influence of biphasic calcium phosphate on osteoporotic bone density. Proceedings of the Latvian Academy of sciences. Section B. 73(2), 185-188.

4. Ananjevs, V., Abolins, A., Locs, J., Salma, I., Skagers, A., Vetra, J., Kasyanov, V. 2020. The Histomorphometry of Rabbit Bone Tissue with Experimental Osteoporosis after Implantation of Biphasic Calcium Phosphate Materials. Key Engineering Materials. 850, 249 253.

\section{Publikācijas Latvijā recenzējamos zinātniskos izdevumos}

1. Anaṇjevs, V., Skaǵers, A., Šalma, I., Šalms, G̣., Vētra, J., Vītiņš, V., Zālīte, V., Stīpniece, L., Kasjanovs, V. 2016. Osteoporotisku apakšžokḷa kaulu biomehānisko rādītāju izmaiņas pēc lokālas pastiprināšanas ar bifāziskajiem kalcija fosfātu biokeramikas materiāliem augšstilba trochanter majus rajonā: eksperimentāls pētījums. RSU zinātnisko rakstu krājums. $258-261$.

\section{Tēzes starptautiskās zinātniskās konferencēs}

1. Ананьев В., Ветра Я. Шалма И., Шалмс Г., Касьянов В., Лочс Я. Изменения биомеханических показателей в нижних челюстях кроликов с экспериментальным остеопорозом после локального использования кальций-фосфатного биокерамического материала в районе большого вертеля бедренной кости. Сборник трудов Нащионального конгресса с международным участием "Паринские чтения 2016" (Паринские чтения 2016, 5-6 мая 2016 г., Минск, Белоруссия), 20-23.

2. Šalms, G̣., Anaṇjevs, V., Kasjanovs, V., Skaǵers, A., Šalma, I., Vētra, J., Zālīte, V.,

Stīpniece, L., Petronis, S. Change of Biomechanical Parameters in the Lower Jaws of Rabbits with Experimental Osteoporosis after Implantation of Calcium-Phosphate Bioceramic Material 
in the Greater Trochanter Region. BALTMATTRIB, Abstract (November 3-4, 2016, Riga, Latvia), 28.

3. Ananjevs, V., Vetra, J., Skagers, A., Salma, I., Locs, J., Kasyanov, V. Calcium phosphate bioceramic material local influence on the osteoporotic bone biomechanical properties (experimental research). 14th Joint Symposium of the Rostock University and Rìga Stradiņš University (24-26 May, 2018, Riga, Latvia).

4. Ananjevs, V., Vetra, J., Skagers, A., Salma, I., Locs, J., Kasyanov, V. Change of the Bone Biomechanical Properties at Rabbits with Experimental Osteoporosis after Implantation of Calcium Phosphate Bioceramic Material. 8th World Congress of Biomechanics (8-12 July, 2018, Dublinā, Īrija).

5. Ananjevs, V., Locs, J., Abolins, A., Salma, I., Vetra, J., Skagers, A., Kasyanov, V. The histomorphometry of rabbits bone tissue with experimental osteoporosis after implantation of biphasic calcium phosphate materials. Materials Science and Applied Chemistry: Abstract (October 24, 2019, Riga, Latvia), 22.

\section{Tēzes Latvijas zinātniskās konferencēs}

1. Anaṇjevs, V., Vētra, J., Skaǵers, A., Kasjanovs, V., Šalma, I., Šalms, G̣., Ločs, J. Osteoporotisku trušu kaulu biomehānisko rādītāju izmaiņas pēc lokālas pastiprināšanas ar bifāziskajiem kalcija fosfātu biokeramikas materiāliem. Rīgas Stradiṇa universitāte. 2017. gada zinātniskā konference: Tēzes (Rīgā, 2017. gada 6.-7. aprīlī), 45.

2. Anaṇjevs, V., Vētra, J., Kasjanovs, V., Skaǵers, A., Šalma, I., Neimane, L. Bifāziska kalcija fostāta biokeramikas materiāla vispārējā ietekme uz osteoporotisku kaulu minerālblīvumu: eksperimentāls pētījums. R̄̄gas Stradinga universitāte. 2018. gada zinātniskā konference: Tēzes (Rīgā, 2018. gada 22.-23. martā), 24.

3. Ananjevs, V., Ananjeva, A., Vetra, J., Skagers, A., Kasjanovs, V. Calcium Phosphate Bioceramic Materials General Influence on Osteoporotic Bone: Experimental Research. Rīgas Stradiña universitāte. 2019. gada starptautiskā konference - zināšanas praksei: Tēzes (Rīgā, 2019. gada 1.-3. aprīlī), 514.

4. Ananjevs, V., Grisulonoks, A., Ananjeva, A., Abolins, A., Salma, I., Salms, G., Vetra, J., Kasjanovs, V., Skagers, A. Histopathology of Rabbits Jaws with Experimental Osteoporosis and Implantation of Biphasic Calcium Phosphates (BCP) in Trochanter Major. Rīgas Stradinga universitāte. 2019. gada strarptautiskā konference - zināšanas praksei: Tēzes (Rīgā, 2019. gada 1.-3. aprīīì), 578. 


\section{Pateicības}

Ar dziḷu cieņu pateicība Dr. med., Dr. habil. med., profesoram Andrejam Skaǵeram un Dr. med., docentei Ilzei Šalmai par atbalstu un padomiem mana promocijas darba tapšanā.

Ĺoti pateicos zinātniskā darba vadītājiem - Dr. habil. med., profesoram Jānim Vētram un Dr. habil. sc. ing., profesoram Vladimiram Kasjanovam par darba vadīšanu, atbalstu un lielu pacietību darba tapšanas laikā.

Pateicos Dr. med., asociētajam profesoram Arnim Āboliņam par palīdzību kaulu paraugu morfoloǵiskā pētījuma veikšanā.

Paldies RSU Stomatologijas Institūta Rentgenologijas nodaļas speciālistiem par lielo praktisko palīdzību kaulu paraugu datortomogrāfijas veikšanā. Īpaša pateicība $D r$.med., asociētajai profesorei Laurai Neimanei par padomiem.

Pateicos Rīgas Stradiṇa universitātei par iespēju studēt doktorantūrā un papildināt savas zināšanas, par finansiālu atbalstu dalībai starptautiskās konferencēs.

Paldies Rīgas Tehniskās universitātes Rūdolfa Cimdina Rīgas biomateriālu inovāciju un attīstības centra speciālistiem par padomiem.

Paldies "Liepadent" zobārstniecības klīnikas vadītājam Armandam Ginteram par padomiem un palīdzību kaulu paraugu sagatavošanā biomehāniskai izpētei.

Vissirsnīgākais paldies un pateicība manai sievai Aleksandrai, dēlam Savēlijam un maniem vecākiem par sapratni, atbalstu un rūpēm. 
Pielikumi 
1. pielikums

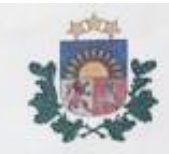

Pàrtikas un veterinarais dienests

\title{
IZMĒĢINĀJUMA PROJEKTA ATLAUUAA Nr. 72 DZİVNIEKA IZMANTOŠANAI PROCEDŪRĀ
}

\author{
Atḷaujas sanēmējs
}

Rīgas Stradina universitātes Eksperimenta dzīvnieku audzētava, Nr. 025479

Izméginājuma dzǐnnieku lietotăjs (nosaukums, PVD registra $\mathrm{Nr}$.)

Izmēginājuma projekta/procedūras nosaukums

Kaulaudu regenerācijas izmainas pēc divfāzisku un trīsfãzisku

biomateriālu implantācijas dzīvniekiem ar eksperimentālu osteoporozi

Hze Šalma

Par visa izmęginājuma projekta IstenoSanu atbiloriga persona

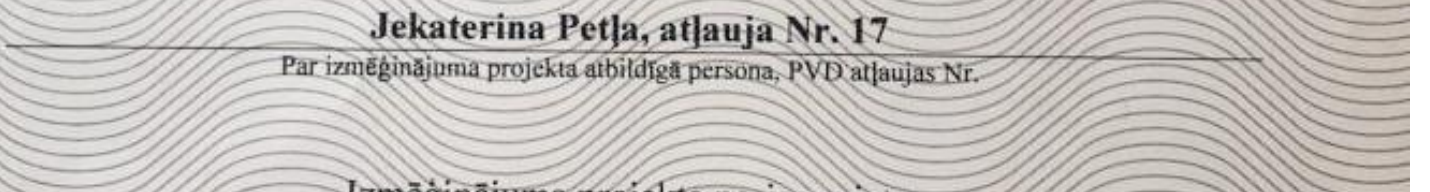

Izmēginäjuma projekta norises vieta

Kristapa Helmana iela 8, Jelgava, LV -3004

Ipašie nosacu um: taktrika adrese

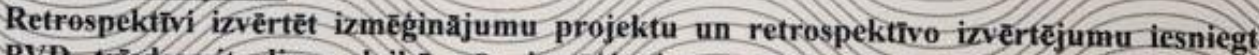
PVD trisdesmit dienu laika pēc izmęginajumu projekta beigăm. Par jebkură procedüras ieviestăm izmainam nekavějoties zinot $\mathrm{PVD}$

\section{Affaujas darbibas laiks no 15.07.2015. fidz 15.05.2016.}


Veidlapa Nr. E-9 (2)

RSU ĒTIKAS KOMITEJAS LĒMUMS NR. 12 / 05.10.2017.

Rìga, Dzirciema iela 16, LV-1007

Tel. 67061596

\begin{tabular}{llll}
\hline \multicolumn{2}{c}{ Komitejas sastāvs } & Kvalifikācija & Nodarbošanās \\
\hline 1. & Profesors Olafs Brūvers & Dr.theo. & teologs \\
2. & Profesore Vija Sīle & Dr.phil. & filozofs \\
3. Asoc.prof. Santa Purviña & Dr.med. & farmakologs \\
4. Asoc.prof. Voldemārs Arnis & Dr.biol. & rehabilitologs \\
5. Profesore Regīna Kleina & Dr.med. & patalogs \\
6. Profesors Guntars Pupelis & Dr.med. & toksikologs \\
7. Asoc.prof. Viesturs Liguts & Dr.med. & \\
8. Docente Iveta Jankovska & Dr.med. & \\
9. Docents Kristaps Circenis & Dr.med. &
\end{tabular}

$\begin{array}{ll}\text { Pieteikuma iesniedzēis: } & \begin{array}{l}\text { Vladislavs Ananjevs } \\ \text { Medicīnas fakultāte, }\end{array}\end{array}$

Medicīnas fakultāte, Doktorantūras nodaḷa

Pētījuma nosaukums: $\quad$ "Osteoporotisku kaulu biomehānisko rādītāju un minerālblīvumu izmainas pēc lokālas pastiprināšanas ar bifăziskajiem kalcija fosfāta biokeramiskajiem materiāliem."

Iesniegšanas datums: $\quad 25.09 .2017$.

Pētījuma protokols: $\quad$ Izskatot augstāk minētā pētījuma pieteikuma materiālus (protokolu) ir redzams, ka pētījuma mērķis tiek sasniegts veicot pētỉjumu ar astoṇus mēnešus veciem sieviešu dzimtes trušiem, nosakot kaulu paraugu biomehānikas īpašǐbas, minerälblīvumu un veicot audu morfologisko izpēti, iegūto datu apstrādi un analīzi, kā arī izsakot priekšlikumus.

Izskaidrošanas formulārs: $\quad$ nav nepieciešams

Piekrišana piedalīties pētījumā: nav nepieciešama

Komitejas lēmums:

piekrist pētījumam

Komitejas priekšsēēetājs Qlafs Brūvers

Tituls: Dr. miss., prof.

Paraksts
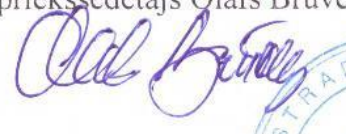

ETTKAS

KOMITEJA

Ẽtikas komitejas sēdes datums: 05.10.2017. 
3. pielikums

\section{DIN EN ISO 178 Determination of flexural properties}

\section{Parameter table:}

Tester

Material

Pre-treatment

Specimen removal

Ananjevs

Labais augsstilbs

Kontrole

Test speed: : $1 \mathrm{~mm} / \mathrm{min}$
Test piece manufacture:

Specimen surface

Testing machine

Load cell

\section{Results:}

\begin{tabular}{c|c|c|c|c|c|c|c|c|c|c}
$\mathrm{Nr}$ & $\mathrm{a} 0$ & $\mathrm{~b} 0$ & $\mathrm{Lv}$ & $\begin{array}{c}\mathrm{Ef} \\
\mathrm{mm}\end{array}$ & $\begin{array}{c}\text { ofC } \\
\mathrm{mm}\end{array}$ & $\begin{array}{c}\text { GPa } \\
\mathrm{GPa}\end{array}$ & $\begin{array}{c}\mathrm{MfM} \\
\mathrm{MPa}\end{array}$ & $\begin{array}{c}\text { ofB } \\
\mathrm{MPa}\end{array}$ & $\begin{array}{c}\text { EfB } \\
\%\end{array}$ & Date \\
\hline 1 & 0,61 & 3,34 & 10 & 12,30 & - & 168,71 & 1,59 & 168,71 & 1,59 & 2017.11 .01$. \\
\hline 2 & 0,63 & 3,34 & 10 & 16,32 & - & 176,68 & 1,22 & 176,68 & 1,22 & 2017.11 .01 \\
\hline 3 & 0,62 & 3,31 & 10 & 11,99 & - & 139,28 & 1,43 & 139,28 & 1,43 & 2017.11 .01 \\
\hline 4 & 0,62 & 3,13 & 10 & 20,66 & - & 201,06 & 1,18 & 201,06 & 1,18 & 2017.11 .01 \\
\hline 5 & 0,63 & 3,21 & 10 & 17,66 & - & 230,97 & 1,56 & 230,97 & 1,56 & 2017.11 .01$.
\end{tabular}

\section{Series graph:}

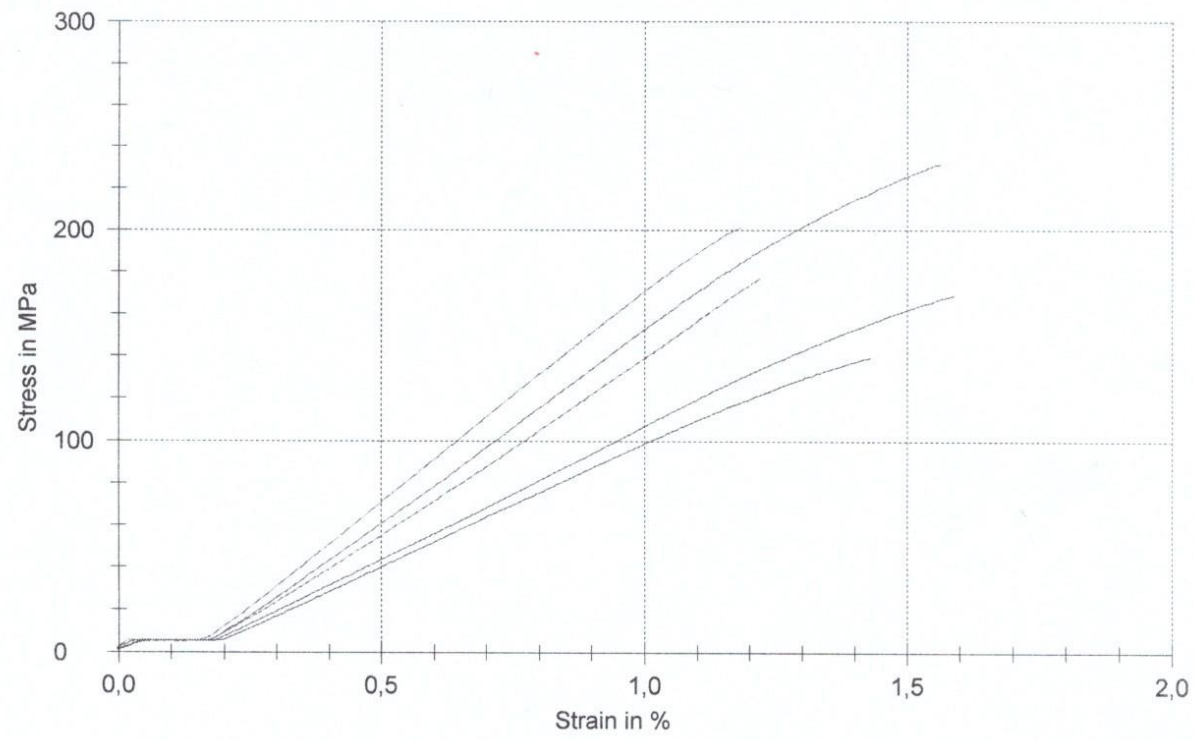

\section{Statistics:}

\begin{tabular}{|c|c|c|c|c|c|c|c|c|c|}
\hline $\begin{array}{c}\text { Series } \\
n=5\end{array}$ & $\begin{array}{c}\mathrm{aO} \\
\mathrm{mm}\end{array}$ & $\begin{array}{l}\mathrm{bO} \\
\mathrm{mm}\end{array}$ & $\begin{array}{l}\mathrm{Lv} \\
\mathrm{mm}\end{array}$ & $\begin{array}{c}\text { Ef } \\
\mathrm{GPa}\end{array}$ & $\begin{array}{c}\sigma \mathrm{fC} \\
\mathrm{MPa}\end{array}$ & $\begin{array}{l}\sigma \mathrm{M} \\
\mathrm{MPa}\end{array}$ & $\begin{array}{c}\varepsilon \mathrm{fM} \\
\%\end{array}$ & $\begin{array}{c}\sigma \mathrm{fB} \\
\mathrm{MPa}\end{array}$ & $\begin{array}{c}\varepsilon f B \\
\%\end{array}$ \\
\hline $\bar{x}$ & 0,622 & 3,266 & 10 & 15,79 & 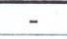 & 183,34 & 1,40 & 183,34 & 1,40 \\
\hline$s$ & 0,00836 & 0,0929 & & 3,6 & - & 34,57 & 0,19 & 34 & 0,19 \\
\hline$v$ & 1,35 & 2,84 & 0,00 & 23,32 & - & 18,86 & 13,51 & 18,86 & 13,51 \\
\hline
\end{tabular}


4. pielikums

\section{DIN EN ISO 178 Determination of flexural properties}

\section{Parameter table:}

$\begin{array}{lll}\text { Tester } & \text { : Ananjevs } & \text { Test piece manufacture: } \\ \text { Material } & \text { : Labais augsstilbs } & \text { Specimen surface } \\ \text { Pre-treatment } & : \text { HAP/TCP } & \text { Testing machine } \\ \text { Specimen removal } & : & \text { Load cell }\end{array}$

Test speed:: $1 \mathrm{~mm} / \mathrm{min}$

\section{Results:}

\begin{tabular}{c|c|c|c|c|c|c|c|c|c|c}
$\mathrm{Nr}$ & $\begin{array}{c}\mathrm{a} 0 \\
\mathrm{~mm}\end{array}$ & $\begin{array}{c}\mathrm{b} 0 \\
\mathrm{~mm}\end{array}$ & $\begin{array}{c}\mathrm{Lv} \\
\mathrm{mm}\end{array}$ & $\begin{array}{c}\mathrm{Ef} \\
\mathrm{GPa}\end{array}$ & $\begin{array}{c}\text { ofC } \\
\mathrm{MPa}\end{array}$ & $\begin{array}{c}\sigma \mathrm{fM} \\
\mathrm{MPa}\end{array}$ & $\begin{array}{c}\varepsilon \mathrm{fM} \\
\%\end{array}$ & $\begin{array}{c}\sigma \mathrm{fB} \\
\mathrm{MPa}\end{array}$ & $\begin{array}{c}\text { \&fB } \\
\%\end{array}$ & Date \\
\hline 1 & 0,63 & 3,17 & 10 & 18,17 & - & 194,61 & 1,17 & 194,61 & 1,17 & 2017.11 .01 \\
\hline 2 & 0,61 & 3,19 & 10 & 20,25 & - & 189,01 & 1,18 & 180,85 & 1,18 & 2017.11 .01 \\
\hline 3 & 0,61 & 3,2 & 10 & 21,10 & - & 207,16 & 1,16 & 207,16 & 1,16 & 2017.11 .01 \\
\hline 4 & 0,63 & 3,26 & 10 & 17,94 & - & 163,11 & 1,05 & 158,35 & 1,06 & 2017.11 .01 \\
\hline 5 & 0,62 & 3 & 10 & 19,87 & - & 195,68 & 1,14 & 195,68 & 1,14 & 2017.11 .01 \\
\hline 6 & 0,63 & 3,2 & 10 & 24,66 & - & 268,11 & 1,34 & 255,63 & 1,35 & 2017.11 .01 \\
\hline 7 & 0,625 & 3,39 & 10 & 17,45 & - & 169,86 & 1,13 & 169,86 & 1,13 & 2017.11 .01$.
\end{tabular}

\section{Series graph:}

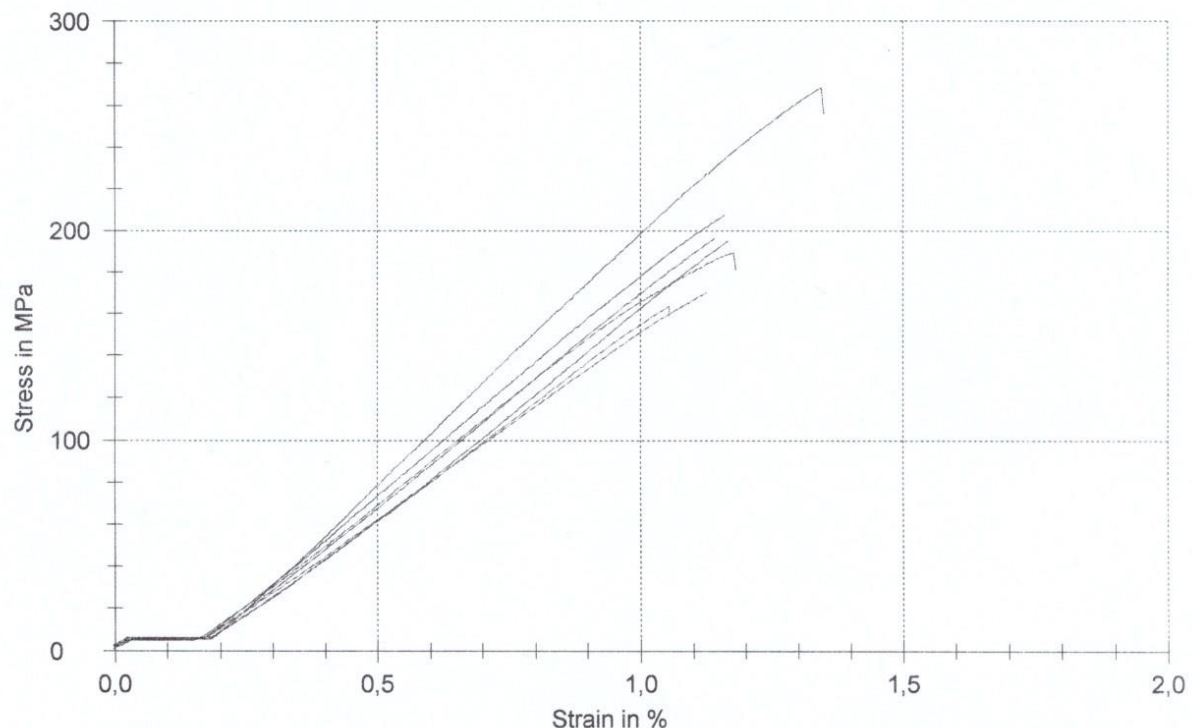

\section{Statistics:}

\begin{tabular}{|c|c|c|c|c|c|c|c|c|c|}
\hline $\begin{array}{c}\text { Series } \\
n=7\end{array}$ & $\begin{array}{l}\mathrm{a0} \\
\mathrm{mm}\end{array}$ & $\begin{array}{l}\text { bO } \\
\mathrm{mm}\end{array}$ & $\begin{array}{l}\mathrm{Lv} \\
\mathrm{mm}\end{array}$ & $\begin{array}{c}\mathrm{Ef} \\
\mathrm{GPa}\end{array}$ & $\begin{array}{c}\sigma \mathrm{fC} \\
\mathrm{MPa}\end{array}$ & $\begin{array}{c}\sigma \mathrm{fM} \\
\mathrm{MPa}\end{array}$ & $\begin{array}{c}\varepsilon f M \\
\%\end{array}$ & $\begin{array}{c}\sigma f B \\
\mathrm{MPa}\end{array}$ & $\begin{array}{c}\varepsilon f B \\
\%\end{array}$ \\
\hline $\bar{x}$ & 0,6221 & 3,201 & 10 & 19,92 & - & 198,22 & 1,17 & 194,59 & 1,17 \\
\hline $\mathrm{s}$ & 0,009063 & 0,116 & 0,000 & 2,49 & 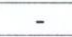 & 34,41 & 0,09 & 31 & 0,09 \\
\hline$v$ & 1,46 & 3,62 & 0,00 & 12,48 & - & 17,36 & 7,57 & 16,25 & 7,68 \\
\hline
\end{tabular}


5. pielikums

\section{DIN EN ISO 178 Determination of flexural properties}

\section{Parameter table:}

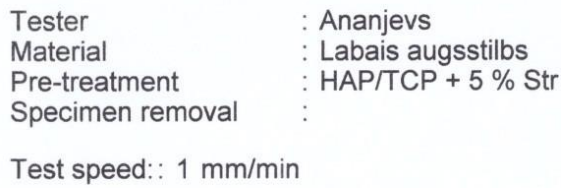

Test speed:: $1 \mathrm{~mm} / \mathrm{min}$

\section{Results:}

\begin{tabular}{|c|c|c|c|c|c|c|c|c|c|c|}
\hline $\mathrm{Nr}$ & $\begin{array}{c}\mathrm{a} 0 \\
\mathrm{~mm}\end{array}$ & $\begin{array}{l}\mathrm{bO} \\
\mathrm{mm}\end{array}$ & $\begin{array}{l}\text { Lv } \\
\mathrm{mm}\end{array}$ & $\begin{array}{c}\mathrm{Ef} \\
\mathrm{GPa}\end{array}$ & $\begin{array}{c}\sigma f C \\
\mathrm{MPa}\end{array}$ & $\begin{array}{c}\sigma \mathrm{fM} \\
\mathrm{MPa}\end{array}$ & $\begin{array}{c}\varepsilon \mathrm{fM} \\
\%\end{array}$ & $\begin{array}{c}\sigma \mathrm{fB} \\
\mathrm{MPa}\end{array}$ & $\begin{array}{c}\varepsilon f B \\
\%\end{array}$ & Date \\
\hline 1 & 0,61 & 3,12 & 10 & 21,88 & - & 208,13 & 1,07 & 208,13 & 1,07 & 2017.11 .15 \\
\hline 2 & 0,63 & 3 & 10 & 21,68 & - & 166,24 & 0,92 & 166,24 & 0,92 & 2017.11 .15 \\
\hline 3 & 0,62 & 3,04 & 10 & 23,73 & - & 232,00 & 1,14 & 231,93 & 1,14 & 2017.11 .15 \\
\hline 4 & 0,63 & 3,17 & 10 & 28,90 & - & 176,14 & 0,77 & 176,14 & 0,77 & 2017.11.15. \\
\hline 5 & 0,61 & 3,17 & 10 & 27,53 & - & 198,01 & 0,86 & 198,01 & 0,86 & 2017.11 .15 \\
\hline 6 & 0,62 & 3,16 & 10 & 18,62 & - & 193,65 & 1,20 & 193,65 & 1,20 & 2017.11.15. \\
\hline 7 & 0,63 & 2,64 & 10 & 21,09 & - & 188,73 & 1,04 & 188,73 & 1,04 & 2017.11.15. \\
\hline
\end{tabular}

\section{Series graph:}

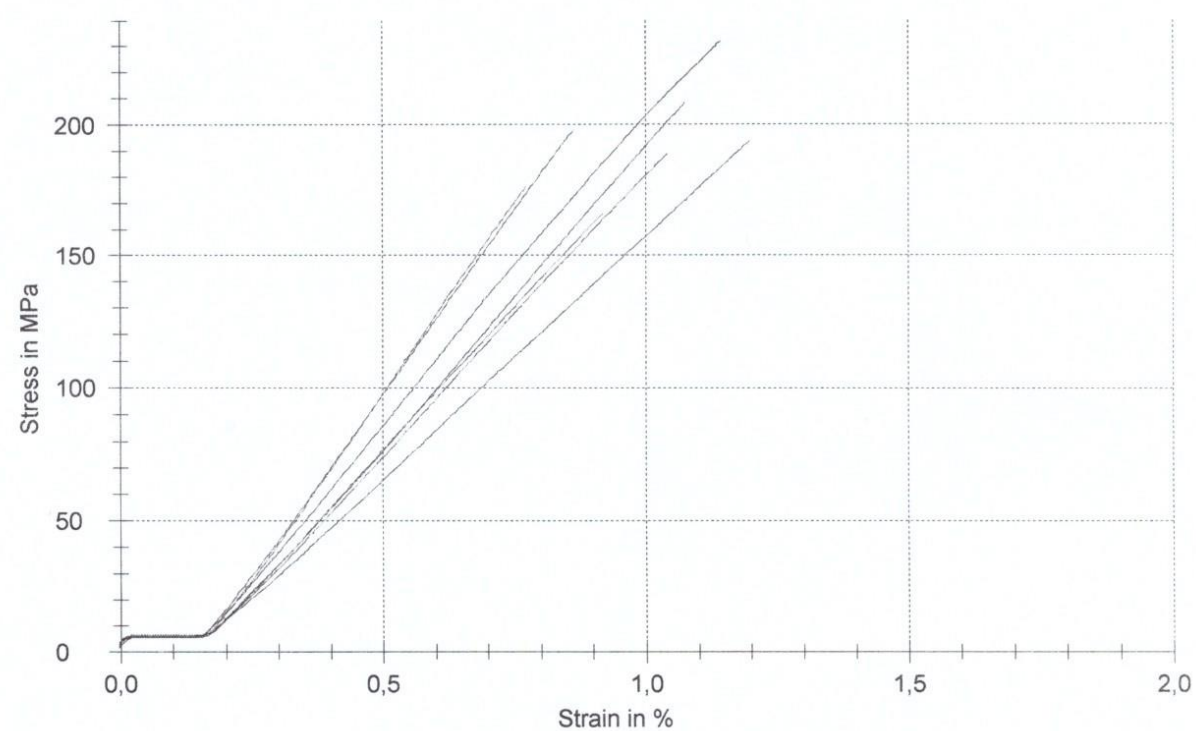

\section{Statistics:}

\begin{tabular}{|c|c|c|c|c|c|c|c|c|c|}
\hline $\begin{array}{c}\text { Series } \\
n=7\end{array}$ & $\begin{array}{l}\mathrm{a} 0 \\
\mathrm{~mm}\end{array}$ & $\begin{array}{l}\text { b0 } \\
\mathrm{mm}\end{array}$ & $\begin{array}{l}\mathrm{Lv} \\
\mathrm{mm}\end{array}$ & $\begin{array}{c}\mathrm{Ef} \\
\mathrm{GPa}\end{array}$ & $\begin{array}{c}\sigma f C \\
\mathrm{MPa}\end{array}$ & $\begin{array}{l}\sigma \mathrm{fM} \\
\mathrm{MPa}\end{array}$ & $\begin{array}{c}\varepsilon f M \\
\%\end{array}$ & $\begin{array}{c}\sigma \mathrm{fB} \\
\mathrm{MPa}\end{array}$ & $\begin{array}{c}\varepsilon f B \\
\%\end{array}$ \\
\hline $\bar{x}$ & 0,6214 & 3,043 & 10 & 23,35 & - & 194,70 & 1,00 & 194,69 & 1,00 \\
\hline$s$ & 0,008997 & 0,1898 & 0,000 & 3,67 & - & 21,50 & 0,16 & 21,48 & 0,16 \\
\hline$v$ & 1,45 & 6,24 & 0,00 & 15,71 & - & 11,04 & 15,50 & 11,03 & 15,50 \\
\hline
\end{tabular}


6. pielikums

\section{DIN EN ISO 178 Determination of flexural properties}

\section{Parameter table:}

$\begin{array}{ll}\text { Tester } & \text { : Ananjevs } \\ \text { Material } & \text { Kreisais augsstilbs } \\ \text { Pre-treatment } & : \text { Kontrole-1 } \\ \text { Specimen removal } & : \\ \text { Test speed: : } 1 \mathrm{~mm} / \mathrm{min}\end{array}$

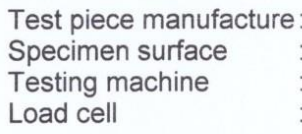

Results:

\begin{tabular}{c|c|c|c|c|c|c|c|c|c|c}
$\mathrm{Nr}$ & $\mathrm{m} 0$ & $\mathrm{b0}$ & $\mathrm{Lv}$ & $\mathrm{Ef}$ & $\begin{array}{c}\sigma \mathrm{fC} \\
\mathrm{mm}\end{array}$ & $\begin{array}{c}\sigma \mathrm{fM} \\
\mathrm{mm}\end{array}$ & $\begin{array}{c}\mathrm{GPa} \\
\mathrm{GPa}\end{array}$ & $\begin{array}{c}\sigma \mathrm{MPa} \\
\mathrm{MPa}\end{array}$ & $\begin{array}{c}\varepsilon \mathrm{MP} \\
\%\end{array}$ & Date \\
\hline 2 & 0,61 & 3,03 & 10 & 14,99 & - & 174,67 & 1,41 & 174,67 & 1,41 & 2017.12 .01$.
\end{tabular}

\section{Series graph:}

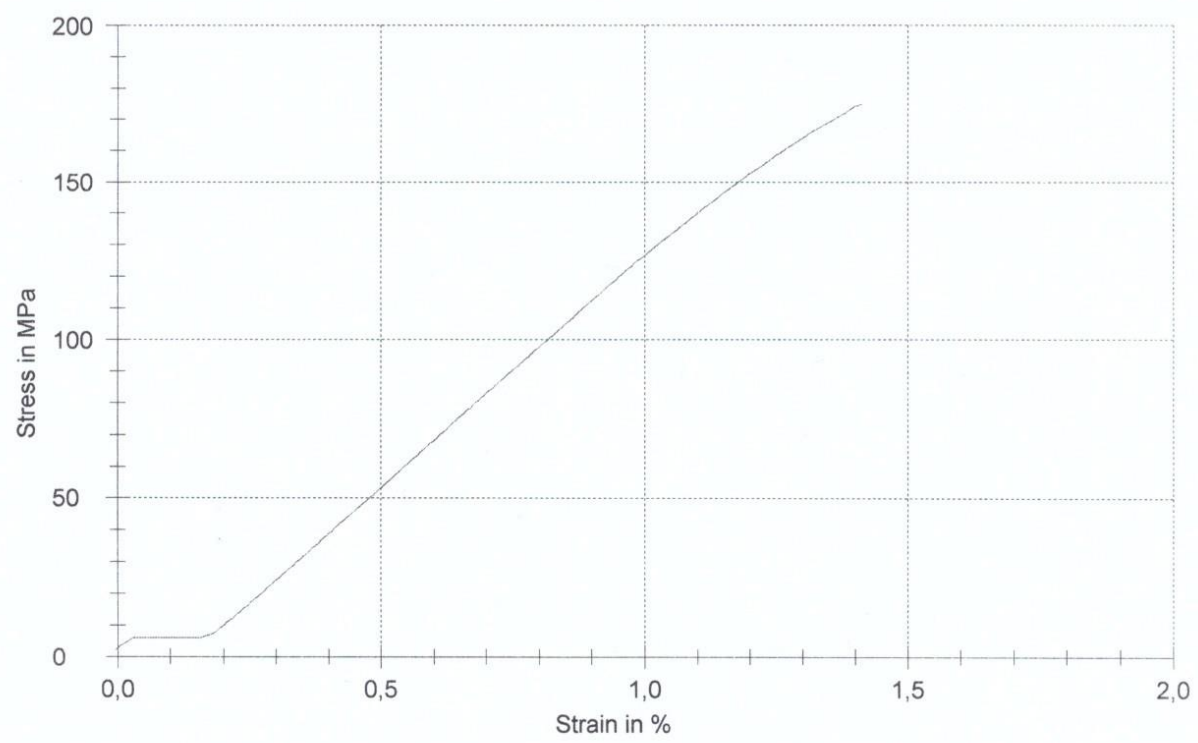

\section{Statistics:}

\begin{tabular}{c|c|c|c|c|c|c|c|c|c}
$\begin{array}{c}\text { Series } \\
\mathrm{n}=1\end{array}$ & $\begin{array}{c}\mathrm{a} 0 \\
\mathrm{~mm}\end{array}$ & $\begin{array}{c}\mathrm{b0} \\
\mathrm{mm}\end{array}$ & $\begin{array}{c}\mathrm{Lv} \\
\mathrm{mm}\end{array}$ & $\begin{array}{c}\mathrm{Ef} \\
\mathrm{GPa}\end{array}$ & $\begin{array}{c}\sigma \mathrm{fC} \\
\mathrm{MPa}\end{array}$ & $\begin{array}{c}\sigma \mathrm{fM} \\
\mathrm{MPa}\end{array}$ & $\begin{array}{c}\mathrm{gfM} \\
\%\end{array}$ & $\begin{array}{c}\sigma \mathrm{fB} \\
\mathrm{MPa}\end{array}$ & $\begin{array}{c}\mathrm{gfB} \\
\%\end{array}$ \\
\hline$\overline{\mathrm{x}}$ & 0,61 & 3,03 & 10 & 14,99 & - & 174,67 & 1,41 & 174,67 & 1,41 \\
\hline $\mathrm{s}$ & - & - & - & - & - & - & - & - & - \\
\hline$v$ & - & - & - & - & - & - & - & - & -
\end{tabular}


7. pielikums

\section{DIN EN ISO 178 Determination of flexural properties}

\section{Parameter table:}

Tester

Material

Pre-treatment

Specimen removal
Ananjevs

Kreisais augsstilbs

Kontrole-2

Test speed: : $1 \mathrm{~mm} / \mathrm{min}$
Test piece manufacture

Specimen surface

Testing machine

Load cell

\section{Results:}

\begin{tabular}{|c|c|c|c|c|c|c|c|c|c|c|}
\hline $\mathrm{Nr}$ & $\begin{array}{l}\mathrm{a0} \\
\mathrm{mm}\end{array}$ & $\begin{array}{l}\mathrm{b0} \\
\mathrm{mm}\end{array}$ & $\begin{array}{l}\text { Lv } \\
\mathrm{mm}\end{array}$ & $\begin{array}{c}\mathrm{Ef} \\
\mathrm{GPa}\end{array}$ & $\begin{array}{c}\sigma f C \\
\mathrm{MPa}\end{array}$ & $\begin{array}{c}\sigma \mathrm{fM} \\
\mathrm{MPa}\end{array}$ & $\begin{array}{c}\varepsilon f \mathrm{M} \\
\%\end{array}$ & $\begin{array}{c}\sigma \mathrm{fB} \\
\mathrm{MPa}\end{array}$ & $\begin{array}{c}\varepsilon f B \\
\%\end{array}$ & Date \\
\hline 1 & 0,6 & 3,2 & 10 & 15,35 & - & 159,98 & 1,17 & 159,98 & 1,17 & 2018.01.17. \\
\hline 2 & 0,6 & 3 & 10 & 14,06 & - & 140,76 & 1,17 & 140,76 & 1,17 & 2018.01.17. \\
\hline 3 & 0,58 & 3,02 & 10 & 18,03 & - & 181,77 & 1,16 & 181,49 & 1,16 & 2018.01.17. \\
\hline 4 & 0,6 & 3,27 & 10 & 11,73 & - & 155,52 & 1,51 & 155,52 & 1,51 & 2018.01 .17 . \\
\hline 5 & 0,61 & 3,1 & 10 & 13,44 & - & 131,93 & 1,33 & 131,67 & 1,33 & 2018.01.17. \\
\hline 8 & 0,62 & 3,1 & 10 & 23,01 & - & 144,27 & 0,80 & 144,27 & 0,80 & 2018.01 .17 \\
\hline 12 & 0,56 & 3.1 & 10 & 14,83 & - & 109,90 & 1.01 & 109,90 & 1.01 & 2018.01 .17 \\
\hline
\end{tabular}

\section{Series graph:}

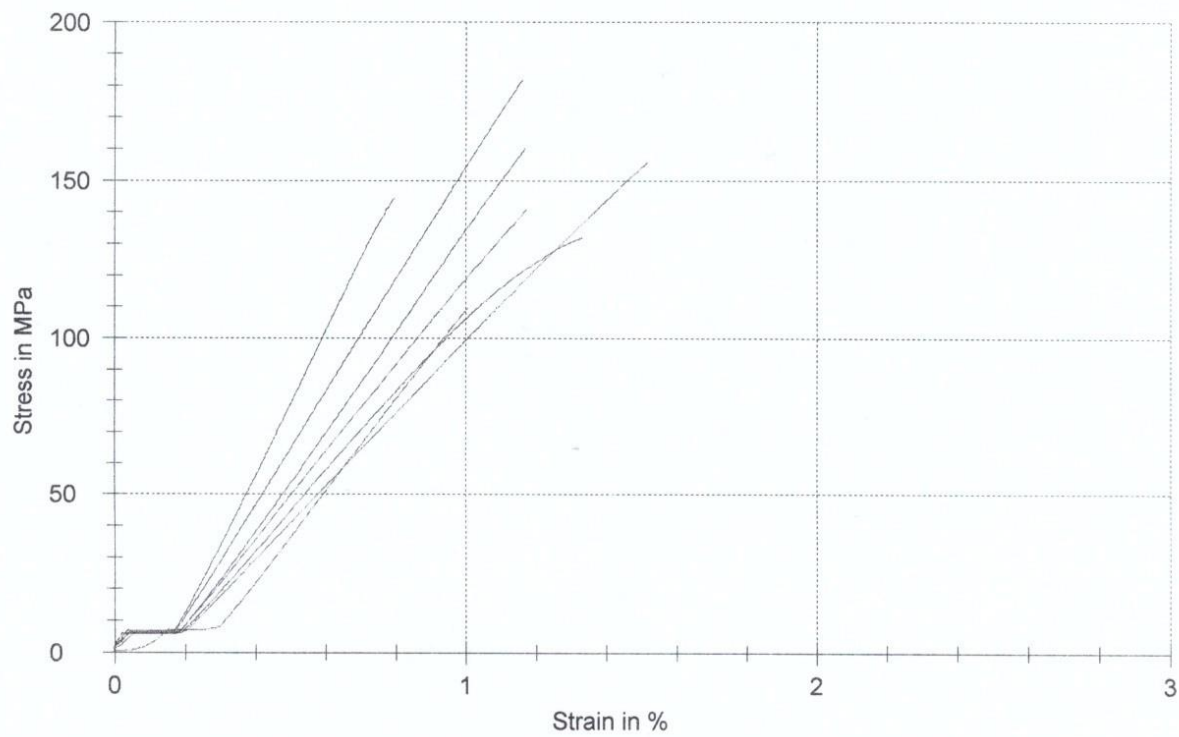

Statistics:

\begin{tabular}{c|c|c|c|r|r|r|r|r|r}
$\begin{array}{c}\text { Series } \\
\mathrm{n}=7\end{array}$ & $\begin{array}{c}\mathrm{a} 0 \\
\mathrm{~mm}\end{array}$ & $\begin{array}{c}\mathrm{b0} \\
\mathrm{mm}\end{array}$ & $\begin{array}{c}\mathrm{Lv} \\
\mathrm{mm}\end{array}$ & $\begin{array}{c}\mathrm{Ef} \\
\mathrm{GPa}\end{array}$ & $\begin{array}{c}\sigma \mathrm{fC} \\
\mathrm{MPa}\end{array}$ & $\begin{array}{c}\sigma \mathrm{fM} \\
\mathrm{MPa}\end{array}$ & $\begin{array}{c}\text { EfM } \\
\%\end{array}$ & $\begin{array}{c}\sigma \mathrm{fB} \\
\mathrm{MPa}\end{array}$ & $\begin{array}{c}\varepsilon f \mathrm{f} \\
\%\end{array}$ \\
\hline$\overline{\mathrm{x}}$ & 0,5957 & 3,113 & 10 & 15,78 & - & 146,30 & 1,16 & 146,23 & 1,16 \\
\hline $\mathrm{s}$ & 0,01988 & 0,09499 & 0,000 & 3,72 & - & 22,72 & 0,23 & 22,67 & 0,23 \\
\hline$v$ & 3,34 & 3,05 & 0,00 & 23,61 & - & 15,53 & 19,46 & 15,51 & 19,46
\end{tabular}


8. pielikums

\title{
DIN EN ISO 178 Determination of flexural properties
}

\section{Parameter table:}

$\begin{array}{ll}\text { Tester } & \text { : Ananjevs } \\ \text { Material } & \text { Kreisais augsstilbs } \\ \text { Pre-treatment } & \text { : HAP/TCP } \\ \text { Specimen removal } & : \\ \text { Test speed: : } 1 \mathrm{~mm} / \mathrm{min}\end{array}$

\author{
Test piece manufacture \\ Specimen surface \\ Testing machine \\ Load cell
}

Results:

\begin{tabular}{c|c|c|c|c|c|c|c|c|c|c}
$\mathrm{Nr}$ & $\begin{array}{c}\mathrm{a} 0 \\
\mathrm{~mm}\end{array}$ & $\begin{array}{c}\mathrm{b} 0 \\
\mathrm{~mm}\end{array}$ & $\begin{array}{c}\mathrm{Lv} \\
\mathrm{mm}\end{array}$ & $\begin{array}{c}\mathrm{Ef} \\
\mathrm{GPa}\end{array}$ & $\begin{array}{c}\sigma \mathrm{fC} \\
\mathrm{MPa}\end{array}$ & $\begin{array}{c}\sigma \mathrm{fM} \\
\mathrm{MPa}\end{array}$ & $\begin{array}{c}\varepsilon \mathrm{fM} \\
\%\end{array}$ & $\begin{array}{c}\sigma \mathrm{fB} \\
\mathrm{MPa}\end{array}$ & $\begin{array}{c}\varepsilon f \mathrm{fB} \\
\%\end{array}$ & Date \\
\hline 1 & 0,61 & 3,12 & 10 & 25,81 & - & 248,62 & 1,14 & 248,62 & 1,14 & 2017.12 .01 \\
\hline 2 & 0,6 & 3,2 & 10 & 19,60 & - & 194,56 & 1,16 & 194,56 & 1,16 & 2017.12 .01 \\
\hline 3 & 0,59 & 3,25 & 10 & 23,64 & - & 209,23 & 1,06 & 209,23 & 1,06 & 2017.12 .01 \\
\hline 4 & 0,61 & 3,05 & 10 & 21,86 & - & 146,59 & 0,82 & 146,59 & 0,82 & 2017.12 .01 \\
\hline 5 & 0,63 & 2,95 & 10 & 18,29 & - & 216,64 & 1,45 & 216,64 & 1,45 & 2017.12 .01 \\
\hline 7 & 0,62 & 2,85 & 10 & 20,91 & - & 164,38 & 0,93 & 157,76 & 0,93 & 2017.12 .01 \\
\hline 8 & 0,62 & 2,45 & 10 & 26,51 & - & 234,22 & 1,05 & 234,22 & 1,05 & 2017.12 .01$.
\end{tabular}

\section{Series graph:}

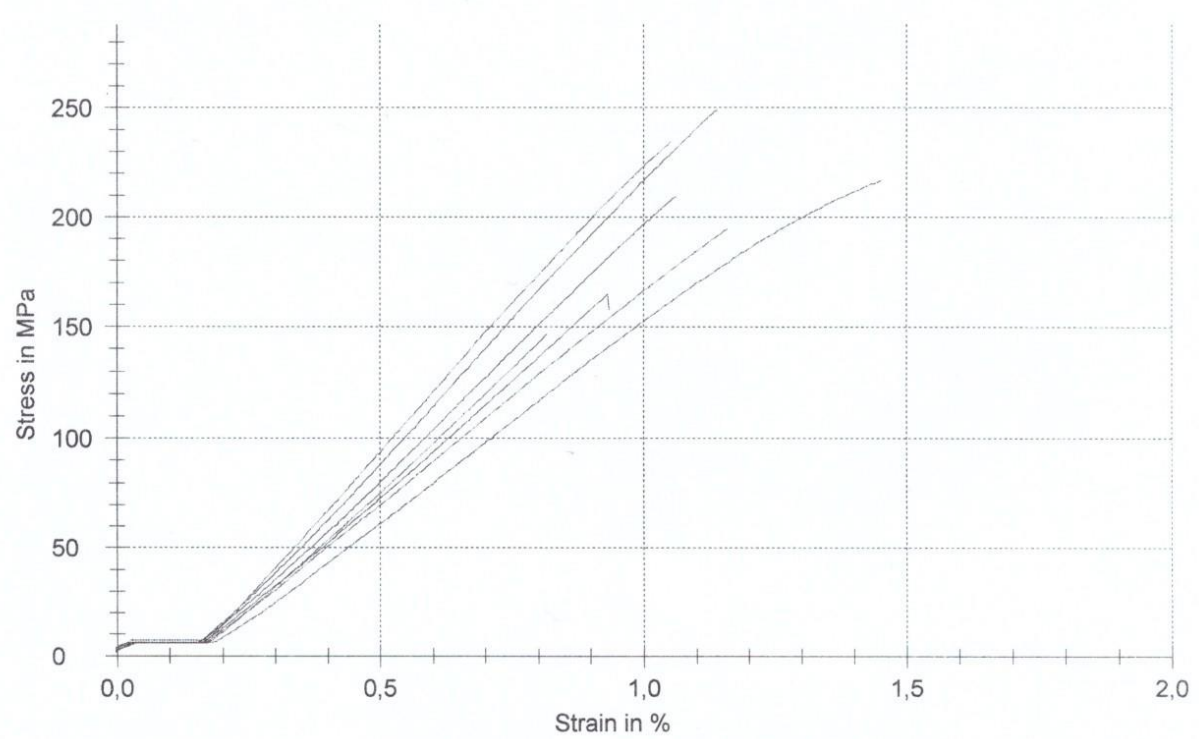

\section{Statistics:}

\begin{tabular}{c|c|c|c|c|c|c|c|c|c}
$\begin{array}{c}\text { Series } \\
\mathrm{n}=7\end{array}$ & $\begin{array}{c}\mathrm{a} 0 \\
\mathrm{~mm}\end{array}$ & $\begin{array}{c}\mathrm{b} 0 \\
\mathrm{~mm}\end{array}$ & $\begin{array}{c}\mathrm{Lv} \\
\mathrm{mm}\end{array}$ & $\begin{array}{c}\mathrm{Ef} \\
\mathrm{GPa}\end{array}$ & $\begin{array}{c}\sigma \mathrm{GC} \\
\mathrm{MPa}\end{array}$ & $\begin{array}{c}\sigma \mathrm{cfM} \\
\mathrm{MPa}\end{array}$ & $\begin{array}{c}\text { \&fM } \\
\%\end{array}$ & $\begin{array}{c}\sigma \mathrm{\sigma B} \\
\mathrm{MPa}\end{array}$ & $\begin{array}{c}\varepsilon f \mathrm{~B} \\
\%\end{array}$ \\
\hline$\overline{\mathrm{x}}$ & 0,6114 & 2,981 & 10 & 22,37 & - & 202,04 & 1,09 & 201,09 & 1,09 \\
\hline $\mathrm{s}$ & 0,01345 & 0,2722 & 0,000 & 3,09 & - & 36,56 & 0,20 & 37,76 & 0,20 \\
\hline$\nu$ & 2,20 & 9,13 & 0,00 & 13,82 & - & 18,09 & 18,44 & 18,78 & 18,39
\end{tabular}


9. pielikums

\section{DIN EN ISO 178 Determination of flexural properties}

\section{Parameter table:}

$\begin{array}{llll}\text { Tester } & \text { : Ananjevs } & \text { Test piece manufacture: } \\ \text { Material } & \text { Kreisais augsstilbs } & \text { Specimen surface } \\ \text { Pre-treatment } & : \text { HAP/TCP }+5 \% \text { Str } & \text { Testing machine } \\ \text { Specimen removal } & : & \text { Load cell }\end{array}$

Test speed:: $1 \mathrm{~mm} / \mathrm{min}$

\section{Results:}

\begin{tabular}{|c|c|c|c|c|c|c|c|c|c|c|}
\hline $\mathrm{Nr}$ & $\begin{array}{c}\mathrm{a} 0 \\
\mathrm{~mm}\end{array}$ & $\begin{array}{l}\text { bo } \\
\mathrm{mm}\end{array}$ & $\begin{array}{l}\text { Lv } \\
\mathrm{mm}\end{array}$ & $\begin{array}{c}\mathrm{Ef} \\
\mathrm{GPa}\end{array}$ & $\begin{array}{c}\sigma f C \\
\mathrm{MPa}\end{array}$ & $\begin{array}{c}\text { ofM } \\
\mathrm{MPa}\end{array}$ & $\begin{array}{c}\varepsilon \mathrm{fM} \\
\%\end{array}$ & $\begin{array}{c}\sigma f B \\
M P a\end{array}$ & $\begin{array}{c}\varepsilon f B \\
\%\end{array}$ & Date \\
\hline 1 & 0,62 & 3,13 & 10 & 22,20 & - & 165,46 & 0,90 & 165,46 & 0,90 & 2017.11 .29 \\
\hline 2 & 0,62 & 3,07 & 10 & 22,11 & - & 238,75 & 1,30 & 238,75 & 1,30 & 2017.11.29 \\
\hline 3 & 0,61 & 3,04 & 10 & 23,41 & - & 166,56 & 0,90 & 164,03 & 0,90 & 2017.11 .29 \\
\hline 4 & 0,62 & 3,02 & 10 & 20,21 & - & 200,25 & 1,14 & 200,25 & 1,14 & 2017.11 .29 \\
\hline 5 & 0,61 & 3,1 & 10 & 24,17 & - & 189,07 & 0,95 & 189,07 & 0,95 & 2017.11.29 \\
\hline 6 & 0,6 & 2,8 & 10 & 20,31 & - & 162,51 & 0,92 & 162,51 & 0,92 & 2017.11 .29 \\
\hline 7 & 0,61 & 3,04 & 10 & 20,29 & - & 177,69 & 1,02 & 177,69 & 1,02 & 2017.11 .29 \\
\hline
\end{tabular}

\section{Series graph:}

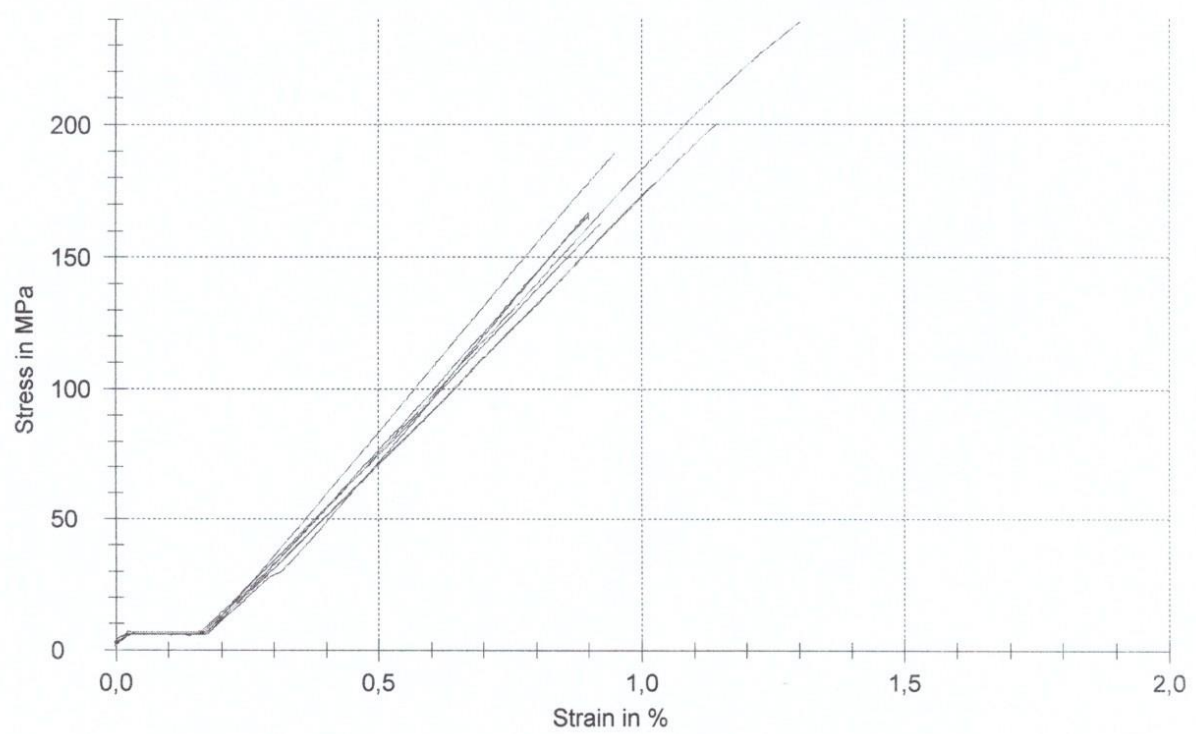

Statistics:

\begin{tabular}{|c|c|c|c|c|c|c|c|c|c|}
\hline $\begin{array}{c}\text { Series } \\
n=7\end{array}$ & $\begin{array}{c}\mathrm{a0} \\
\mathrm{mm}\end{array}$ & $\begin{array}{l}\text { b0 } \\
\mathrm{mm}\end{array}$ & $\begin{array}{l}\mathrm{Lv} \\
\mathrm{mm}\end{array}$ & $\begin{array}{c}\text { Ef } \\
\mathrm{GPa}\end{array}$ & $\begin{array}{c}\sigma \mathrm{fC} \\
\mathrm{MPa}\end{array}$ & $\begin{array}{c}\text { ofM } \\
\mathrm{MPa}\end{array}$ & $\begin{array}{c}\varepsilon \mathrm{fM} \\
\%\end{array}$ & $\begin{array}{c}\sigma f B \\
\mathrm{MPa}\end{array}$ & $\begin{array}{c}\varepsilon f B \\
\%\end{array}$ \\
\hline $\bar{x}$ & 0,6129 & 3,029 & 10 & 21,81 & - & 185,76 & 1,02 & 185,39 & 1,02 \\
\hline $\mathrm{s}$ & 0,0 & 1078 & 0,0 & 1,6 & - & & 0,15 & 27,44 & 0,15 \\
\hline$v$ & 1,23 & 3,56 & 0,00 & 7,37 & - & 14,60 & 14,98 & 14,80 & 14,96 \\
\hline
\end{tabular}


10. pielikums

\section{DIN EN ISO 178 Determination of flexural properties}

\section{Parameter table:}

$\begin{array}{lll}\text { Tester } & : \text { Ananjevs } & \text { Test piece manufacture: } \\ \text { Material } & : \text { Apakszoklis } & \text { Specimen surface } \\ \text { Pre-treatment } & : \text { Kontrole-1 } & \text { Testing machine } \\ \text { Specimen removal } & : & \text { Load cell }\end{array}$

Test speed:: $1 \mathrm{~mm} / \mathrm{min}$

\section{Results:}

\begin{tabular}{|c|c|c|c|c|c|c|c|c|c|c|}
\hline $\mathrm{Nr}$ & $\begin{array}{c}\mathrm{a} 0 \\
\mathrm{~mm}\end{array}$ & $\begin{array}{l}\text { b0 } \\
\text { mm }\end{array}$ & $\begin{array}{l}\text { Lv } \\
\mathrm{mm}\end{array}$ & $\begin{array}{c}\mathrm{Ef} \\
\mathrm{GPa}\end{array}$ & $\begin{array}{l}\text { ofC } \\
\mathrm{MPa}\end{array}$ & $\begin{array}{c}\text { ofM } \\
\mathrm{MPa}\end{array}$ & $\begin{array}{c}\text { EfM } \\
\%\end{array}$ & $\begin{array}{c}\sigma f B \\
\mathrm{MPa}\end{array}$ & $\begin{array}{c}\varepsilon f B \\
\%\end{array}$ & Date \\
\hline 1 & 0,32 & 3,4 & 10 & 4,09 & - & 77,06 & 2,45 & - & - & \\
\hline 2 & & 3,2 & 10 & 4,28 & & 64,46 & 2,02 & & 2,07 & \\
\hline 0 & 0,34 & 2,92 & 10 & 4,55 & - & 83,67 & 2,11 & 82,86 & 2,15 & 2017.12.01. \\
\hline
\end{tabular}

\section{Series graph:}

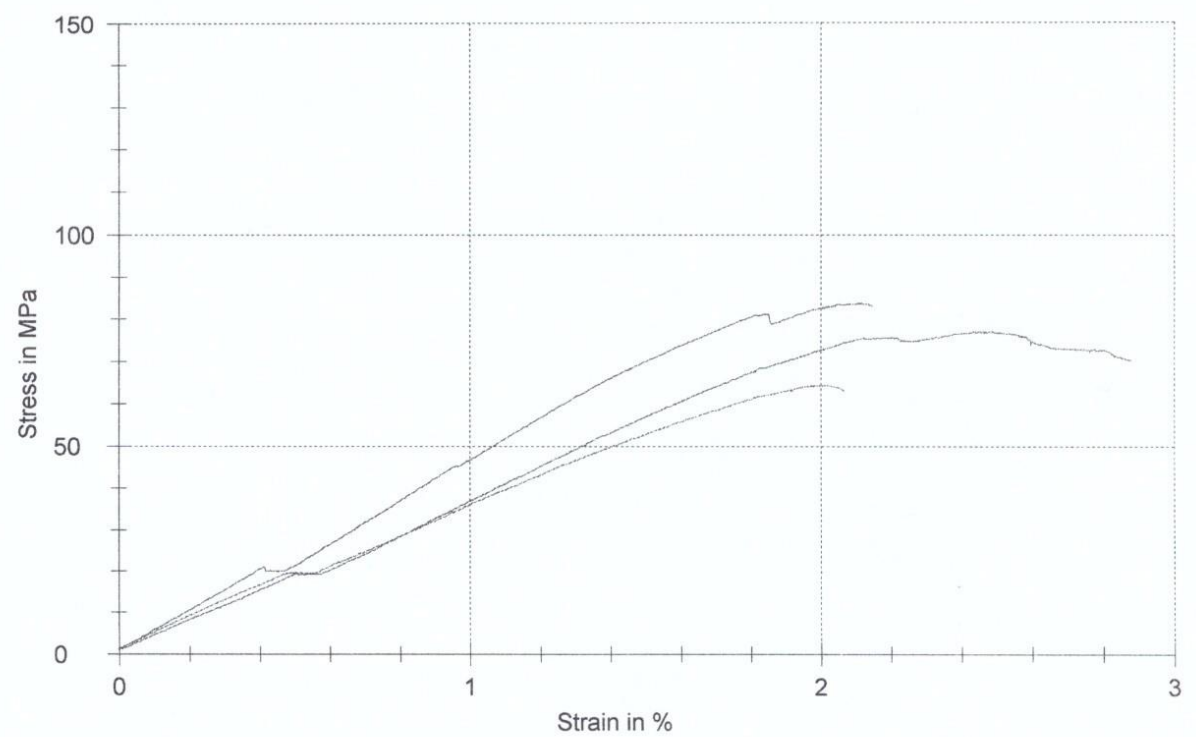

\section{Statistics:}

\begin{tabular}{c|c|c|c|c|c|c|c|c|c}
$\begin{array}{c}\text { Series } \\
n=3\end{array}$ & $\begin{array}{c}\text { a0 } \\
\mathrm{mm}\end{array}$ & $\begin{array}{c}\mathrm{b} 0 \\
\mathrm{~mm}\end{array}$ & $\begin{array}{c}\mathrm{Lv} \\
\mathrm{mm}\end{array}$ & $\begin{array}{c}\mathrm{Ef} \\
\mathrm{GPa}\end{array}$ & $\begin{array}{c}\sigma \mathrm{GC} \\
\mathrm{MPa}\end{array}$ & $\begin{array}{c}\sigma \mathrm{fM} \\
\mathrm{MPa}\end{array}$ & $\begin{array}{c}\mathrm{\varepsilon fM} \\
\%\end{array}$ & $\begin{array}{c}\sigma \mathrm{fB} \\
\mathrm{MPa}\end{array}$ & $\begin{array}{c}\varepsilon f \mathrm{\%} \\
\%\end{array}$ \\
\hline$\overline{\mathrm{x}}$ & 0,3267 & 3,24 & 10 & 4,31 & - & 75,06 & 2,19 & 73,05 & 2,11 \\
\hline $\mathrm{s}$ & 0,01155 & 0,2771 & 0,000 & 0,23 & - & 9,76 & 0,23 & 13,88 & 0,06 \\
\hline$v$ & 3,53 & 8,55 & 0,00 & 5,42 & - & 13,00 & 10,33 & 19,01 & 2,78
\end{tabular}


11. pielikums

\section{DIN EN ISO 178 Determination of flexural properties}

\section{Parameter table:}

$\begin{array}{lll}\text { Tester } & : \text { Ananjevs } & \text { Test piece manufacture: } \\ \text { Material } & \text { Apakszoklis } & \text { Specimen surface } \\ \text { Pre-treatment } & : \text { Kontrole-2 } & \text { Testing machine } \\ \text { Specimen removal } & : & \text { Load cell } \\ \text { Test speed: } 1 \mathrm{~mm} / \mathrm{min} & \end{array}$

Results:

\begin{tabular}{|c|c|c|c|c|c|c|c|c|c|c|}
\hline $\mathrm{Nr}$ & $\begin{array}{c}\mathrm{a} 0 \\
\mathrm{~mm}\end{array}$ & $\begin{array}{c}\mathrm{b0} \\
\mathrm{mm}\end{array}$ & $\begin{array}{l}\text { Lv } \\
\mathrm{mm}\end{array}$ & $\begin{array}{c}\mathrm{Ef} \\
\mathrm{GPa}\end{array}$ & $\begin{array}{c}\sigma f C \\
\mathrm{MPa}\end{array}$ & $\begin{array}{c}\sigma \mathrm{fM} \\
\mathrm{MPa}\end{array}$ & $\begin{array}{c}\varepsilon f M \\
\%\end{array}$ & $\begin{array}{c}\sigma \mathrm{fB} \\
\mathrm{MPa}\end{array}$ & $\begin{array}{c}\varepsilon f B \\
\%\end{array}$ & Date \\
\hline 1 & 0,32 & 3,26 & 10 & 7,43 & 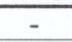 & 132,67 & 2,49 & 131,74 & 2,53 & 2018.01 .17 \\
\hline 3 & 0,32 & 3,23 & 10 & 5,83 & - & 95,99 & 1,87 & 95,99 & 1,87 & 2018.01 .17 \\
\hline 4 & 0,31 & 2,76 & 10 & 4,67 & - & 78,59 & 2,06 & 71,25 & 2,39 & 2018.01 .17 \\
\hline 5 & 0,3 & 3,55 & 10 & 6,62 & - & 96,04 & 1,67 & 95,83 & 1,68 & 2018.01 .17 \\
\hline 10 & 0,33 & 3,26 & 10 & 7,52 & - & 112,79 & 1,72 & 112,17 & 1,74 & 2018.01 .17 \\
\hline
\end{tabular}

\section{Series graph:}

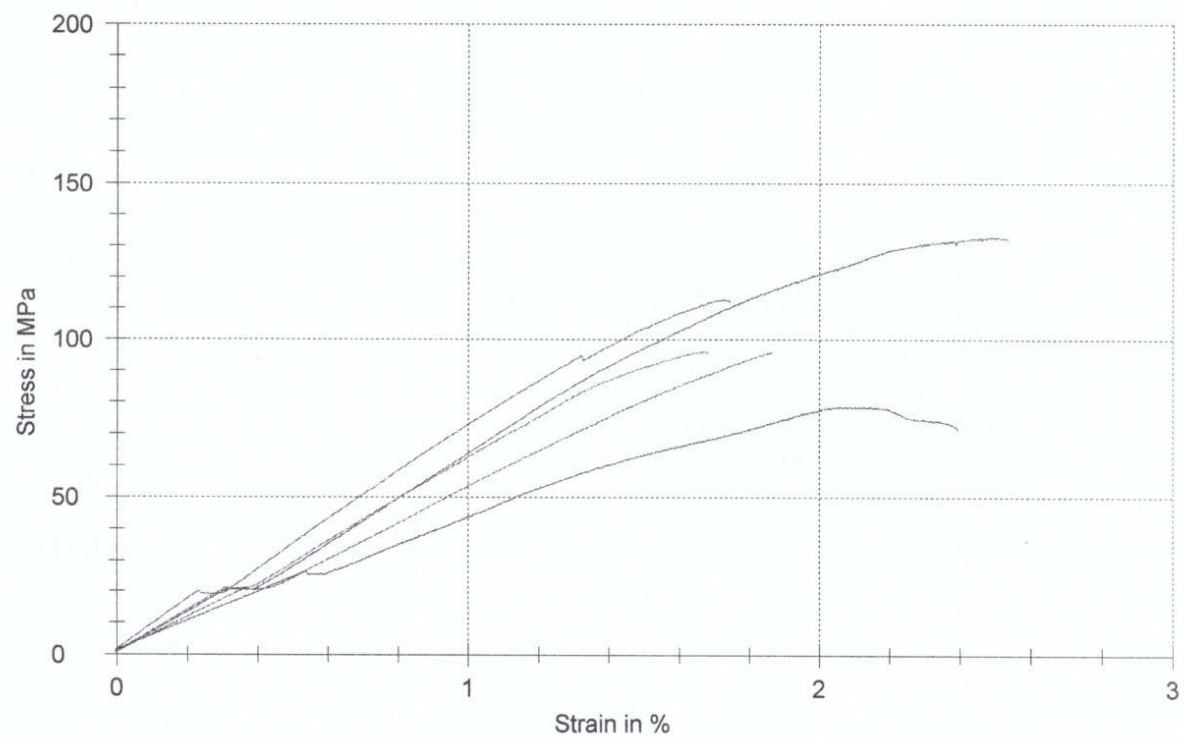

\section{Statistics:}

\begin{tabular}{c|c|c|c|c|c|c|c|c|c}
$\begin{array}{c}\text { Series } \\
\mathrm{n}=5\end{array}$ & $\begin{array}{c}\mathrm{a} 0 \\
\mathrm{~mm}\end{array}$ & $\begin{array}{c}\mathrm{b0} \\
\mathrm{mm}\end{array}$ & $\begin{array}{c}\mathrm{Lv} \\
\mathrm{mm}\end{array}$ & $\begin{array}{c}\mathrm{Ef} \\
\mathrm{GPa}\end{array}$ & $\begin{array}{c}\sigma \mathrm{fC} \\
\mathrm{MPa}\end{array}$ & $\begin{array}{c}\sigma \mathrm{fM} \\
\mathrm{MPa}\end{array}$ & $\begin{array}{c}\varepsilon \mathrm{fM} \\
\%\end{array}$ & $\begin{array}{c}\sigma \mathrm{fB} \\
\mathrm{MPa}\end{array}$ & $\begin{array}{c}\varepsilon f B \\
\%\end{array}$ \\
\hline$\overline{\mathrm{x}}$ & 0,316 & 3,212 & 10 & 6,41 & - & 103,22 & 1,96 & 101,40 & 2,04 \\
\hline $\mathrm{s}$ & 0,0114 & 0,2844 & 0,000 & 1,19 & - & 20,43 & 0,33 & 22,39 & 0,39 \\
\hline$v$ & 3,61 & 8,85 & 0,00 & 18,62 & - & 19,79 & 16,85 & 22,08 & 19,13
\end{tabular}


12. pielikums

01.12 .2017

\section{DIN EN ISO 178 Determination of flexural properties}

\section{Parameter table:}

$\begin{array}{lll}\text { Tester } & : \text { Ananjevs } & \text { Test piece manufacture: } \\ \text { Material } & : \text { Apakszoklis } & \text { Specimen surface } \\ \text { Pre-treatment } & : \text { HAP/TCP } & \text { Testing machine } \\ \text { Specimen removal } & : & \text { Load cell } \\ \text { Test speed:: } 1 \mathrm{~mm} / \mathrm{min} & \end{array}$

\section{Results:}

\begin{tabular}{|c|c|c|c|c|c|c|c|c|c|c|}
\hline $\mathrm{Nr}$ & $\begin{array}{c}\mathrm{a} 0 \\
\mathrm{~mm}\end{array}$ & $\begin{array}{l}\mathrm{b} 0 \\
\mathrm{~mm}\end{array}$ & $\begin{array}{l}\mathrm{Lv} \\
\mathrm{mm}\end{array}$ & $\begin{array}{c}\mathrm{Ef} \\
\mathrm{GPa}\end{array}$ & $\begin{array}{l}\sigma \mathrm{fC} \\
\mathrm{MPa}\end{array}$ & $\begin{array}{c}\sigma \mathrm{fM} \\
\mathrm{MPa}\end{array}$ & $\begin{array}{c}\varepsilon \mathrm{fM} \\
\%\end{array}$ & $\begin{array}{c}\sigma f B \\
\mathrm{MPa}\end{array}$ & $\begin{array}{c}\varepsilon f B \\
\%\end{array}$ & Date \\
\hline 1 & 0,34 & 3,19 & 10 & 16,08 & - & 196,14 & 1,25 & 196,14 & 1,25 & 2017. \\
\hline 2 & 0,33 & 3,37 & 10 & 11, & - & 155 & 1,46 & & 1,58 & 2.01 \\
\hline 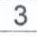 & 0 & 3,12 & 10 & 11,2 & - & & 1,58 & & 1,58 & 2.01 \\
\hline 4 & 0,31 & 3,12 & 10 & 12,3 & - & 155,14 & 1,49 & 155,14 & 1,49 & 20 \\
\hline 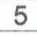 & 0,34 & 3,06 & 10 & 12,44 & 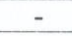 & 183,01 & 1,47 & 183,01 & 1,47 & 2017. \\
\hline 6 & 0,31 & 3,12 & 10 & 17,71 & - & 202,71 & 1,27 & 201,58 & 1,27 & 2017.12.01 \\
\hline 7 & 0,33 & 3,2 & 10 & 19,40 & - & 253,25 & 1,38 & 253,25 & 1,38 & 2017.12.01 \\
\hline
\end{tabular}

\section{Series graph:}

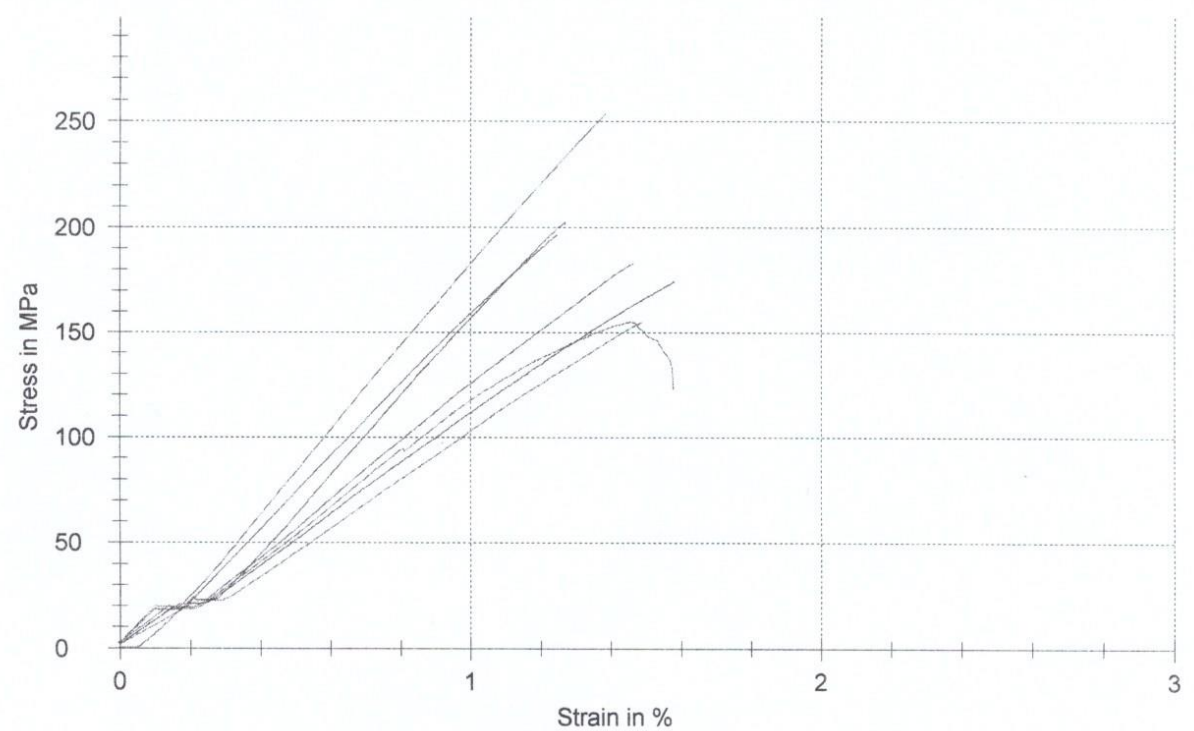

\section{Statistics:}

\begin{tabular}{c|c|c|c|c|c|c|c|c|c}
$\begin{array}{c}\text { Series } \\
\mathrm{n}=7\end{array}$ & $\begin{array}{c}\mathrm{a} 0 \\
\mathrm{~mm}\end{array}$ & $\begin{array}{c}\mathrm{b} 0 \\
\mathrm{~mm}\end{array}$ & $\begin{array}{c}\mathrm{Lv} \\
\mathrm{mm}\end{array}$ & $\begin{array}{c}\mathrm{Ef} \\
\mathrm{GPa}\end{array}$ & $\begin{array}{c}\sigma \mathrm{\sigma C} \\
\mathrm{MPa}\end{array}$ & $\begin{array}{c}\sigma \mathrm{fM} \\
\mathrm{MPa}\end{array}$ & $\begin{array}{c}\mathrm{EfM} \\
\%\end{array}$ & $\begin{array}{c}\sigma \mathrm{fB} \\
\mathrm{MPa}\end{array}$ & $\begin{array}{c}\varepsilon f \mathrm{~B} \\
\%\end{array}$ \\
\hline$\overline{\mathrm{x}}$ & 0,3257 & 3,169 & 10 & 14,39 & - & 188,56 & 1,41 & 183,72 & 1,43 \\
\hline $\mathrm{s}$ & 0,01272 & 0,1007 & 0,000 & 3,29 & - & 33,92 & 0,12 & 40,74 & 0,14 \\
\hline$v$ & 3,91 & 3,18 & 0,00 & 22,86 & - & 17,99 & 8,58 & 22,18 & 9,49
\end{tabular}


13. pielikums

01.12 .2017

\section{DIN EN ISO 178 Determination of flexural properties}

\section{Parameter table:}

$\begin{array}{lll}\text { Tester } & \text { : Ananjevs } & \text { Test piece manufacture: } \\ \text { Material } & \text { Apakszoklis } & \text { Specimen surface } \\ \text { Pre-treatment } & \text { : HAP/TCP } & \text { Testing machine } \\ \text { Specimen removal } & : & \text { Load cell } \\ \text { Test speed:: } 1 \mathrm{~mm} / \mathrm{min} & \end{array}$

\section{Results:}

\begin{tabular}{|c|c|c|c|c|c|c|c|c|c|c|}
\hline $\mathrm{Nr}$ & $\begin{array}{c}\mathrm{a} 0 \\
\mathrm{~mm}\end{array}$ & $\begin{array}{l}\mathrm{b} 0 \\
\mathrm{~mm}\end{array}$ & $\begin{array}{l}\mathrm{Lv} \\
\mathrm{mm}\end{array}$ & $\begin{array}{c}\mathrm{Ef} \\
\mathrm{GPa}\end{array}$ & $\begin{array}{l}\sigma \mathrm{fC} \\
\mathrm{MPa}\end{array}$ & $\begin{array}{c}\sigma \mathrm{fM} \\
\mathrm{MPa}\end{array}$ & $\begin{array}{c}\varepsilon \mathrm{fM} \\
\%\end{array}$ & $\begin{array}{c}\sigma f B \\
\mathrm{MPa}\end{array}$ & $\begin{array}{c}\varepsilon f B \\
\%\end{array}$ & Date \\
\hline 1 & 0,34 & 3,19 & 10 & 16,08 & - & 196,14 & 1,25 & 196,14 & 1,25 & 2017. \\
\hline 2 & 0,33 & 3,37 & 10 & 11, & - & 155 & 1,46 & & 1,58 & 2.01 \\
\hline 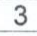 & 0 & 3,12 & 10 & 11,2 & - & & 1,58 & & 1,58 & 2.01 \\
\hline 4 & 0,31 & 3,12 & 10 & 12,3 & - & 155,14 & 1,49 & 155,14 & 1,49 & 20 \\
\hline 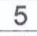 & 0,34 & 3,06 & 10 & 12,44 & 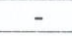 & 183,01 & 1,47 & 183,01 & 1,47 & 2017. \\
\hline 6 & 0,31 & 3,12 & 10 & 17,71 & - & 202,71 & 1,27 & 201,58 & 1,27 & 2017.12.01 \\
\hline 7 & 0,33 & 3,2 & 10 & 19,40 & - & 253,25 & 1,38 & 253,25 & 1,38 & 2017.12.01 \\
\hline
\end{tabular}

\section{Series graph:}

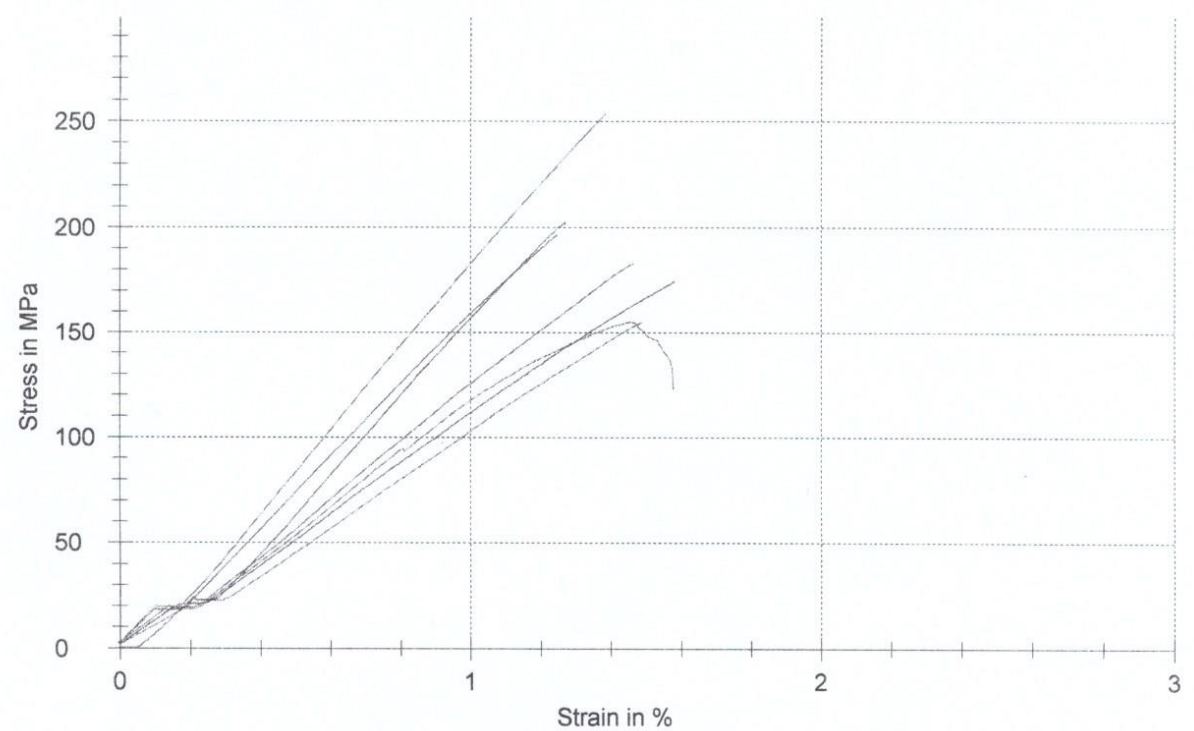

\section{Statistics:}

\begin{tabular}{c|c|c|c|c|c|c|c|c|c}
$\begin{array}{c}\text { Series } \\
\mathrm{n}=7\end{array}$ & $\begin{array}{c}\mathrm{a} 0 \\
\mathrm{~mm}\end{array}$ & $\begin{array}{c}\mathrm{b} 0 \\
\mathrm{~mm}\end{array}$ & $\begin{array}{c}\mathrm{Lv} \\
\mathrm{mm}\end{array}$ & $\begin{array}{c}\mathrm{Ef} \\
\mathrm{GPa}\end{array}$ & $\begin{array}{c}\sigma \mathrm{\sigma C} \\
\mathrm{MPa}\end{array}$ & $\begin{array}{c}\sigma \mathrm{fM} \\
\mathrm{MPa}\end{array}$ & $\begin{array}{c}\mathrm{EfM} \\
\%\end{array}$ & $\begin{array}{c}\sigma \mathrm{fB} \\
\mathrm{MPa}\end{array}$ & $\begin{array}{c}\varepsilon f \mathrm{~B} \\
\%\end{array}$ \\
\hline$\overline{\mathrm{x}}$ & 0,3257 & 3,169 & 10 & 14,39 & - & 188,56 & 1,41 & 183,72 & 1,43 \\
\hline $\mathrm{s}$ & 0,01272 & 0,1007 & 0,000 & 3,29 & - & 33,92 & 0,12 & 40,74 & 0,14 \\
\hline$v$ & 3,91 & 3,18 & 0,00 & 22,86 & - & 17,99 & 8,58 & 22,18 & 9,49
\end{tabular}


14. pielikums

\section{DIN EN ISO 178 Determination of flexural properties}

\section{Parameter table:}

Tester

Material

Pre-treatment

Specimen removal

\section{Ananjevs}

Apakszoklis

HAP/TCP + $5 \%$ Str

Test piece manufacture:

Specimen surface

Testing machine

Load cell

Test speed: : $1 \mathrm{~mm} / \mathrm{min}$

\section{Results:}

\begin{tabular}{c|c|c|c|c|c|c|c|c|c|c}
$\mathrm{Nr}$ & $\mathrm{mm}$ & $\mathrm{b0}$ & $\mathrm{Lv}$ & $\begin{array}{c}\mathrm{Ef} \\
\mathrm{mm}\end{array}$ & $\begin{array}{c}\sigma \mathrm{fC} \\
\mathrm{mm}\end{array}$ & $\begin{array}{c}\text { GPa } \\
\mathrm{MPa}\end{array}$ & $\begin{array}{c}\mathrm{gfM} \\
\mathrm{MPa}\end{array}$ & $\begin{array}{c}\sigma \mathrm{fB} \\
\mathrm{MPa}\end{array}$ & $\begin{array}{c}\text { ffB } \\
\%\end{array}$ & Date \\
\hline 1 & 0,33 & 3,42 & 10 & 17,63 & - & 249,57 & 1,93 & 240,61 & 2,08 & $2018 \cdot 01 \cdot 10$. \\
\hline 2 & 0,33 & 3,46 & 10 & 10,02 & - & 221,75 & 2,95 & - & - & $2018 \cdot 01 \cdot 10$. \\
\hline 3 & 0,31 & 3,51 & 10 & 16,63 & - & 254,94 & 1,64 & 254,94 & 1,64 & $2018 \cdot 01 \cdot 10$. \\
\hline 4 & 0,31 & 3,32 & 10 & 30,31 & - & 242,27 & 0,90 & 242,27 & 0,90 & $2018 \cdot 01 \cdot 10$. \\
\hline 6 & 0,32 & 3,48 & 10 & 14,97 & - & 145,30 & 1,09 & 145,30 & 1,09 & $2018 \cdot 01 \cdot 10$. \\
\hline 7 & 0,3 & 3,32 & 10 & 13,78 & - & 241,53 & 2,07 & 241,53 & 2,07 & $2018 \cdot 01 \cdot 10$.
\end{tabular}

\section{Series graph:}

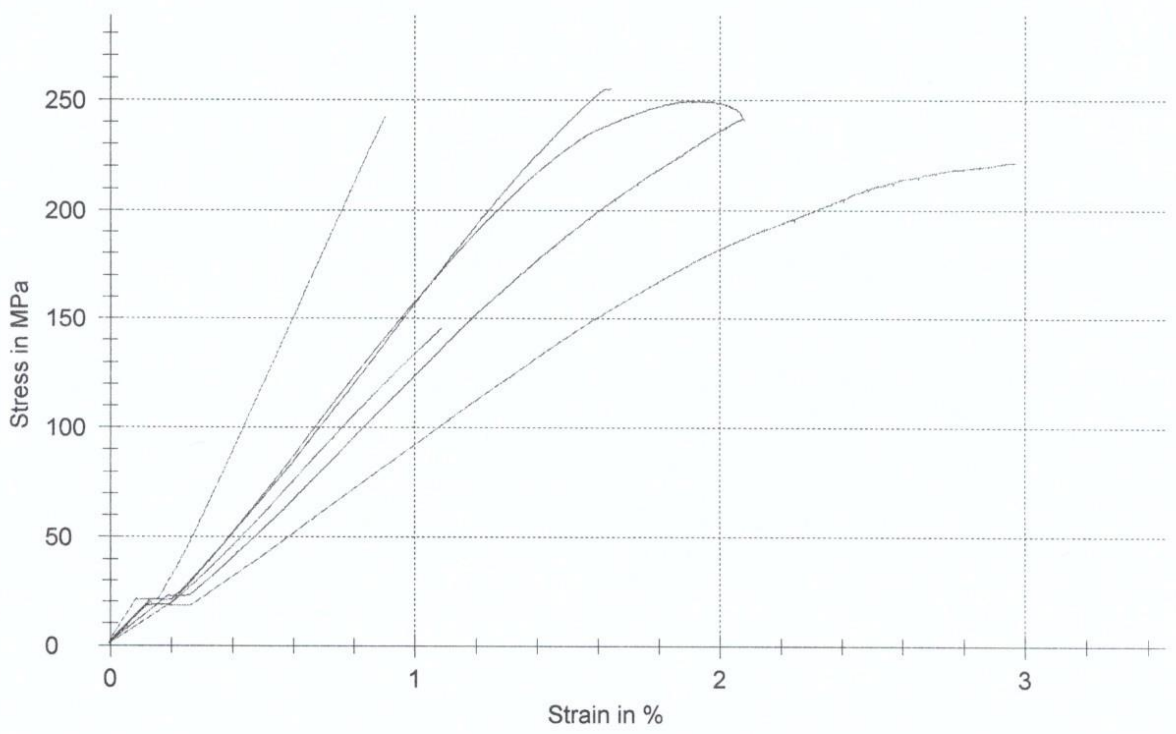

Statistics:

\begin{tabular}{c|c|c|c|r|c|c|c|c|c}
$\begin{array}{c}\text { Series } \\
\mathrm{n}=6\end{array}$ & $\begin{array}{c}\mathrm{a} 0 \\
\mathrm{~mm}\end{array}$ & $\begin{array}{c}\mathrm{b0} \\
\mathrm{mm}\end{array}$ & $\begin{array}{c}\mathrm{Lv} \\
\mathrm{mm}\end{array}$ & $\begin{array}{c}\mathrm{Ef} \\
\mathrm{GPa}\end{array}$ & $\begin{array}{c}\sigma \mathrm{fC} \\
\mathrm{MPa}\end{array}$ & $\begin{array}{c}\sigma \mathrm{fM} \\
\mathrm{MPa}\end{array}$ & $\begin{array}{c}\varepsilon f M \\
\%\end{array}$ & $\begin{array}{c}\sigma f B \\
\mathrm{MPa}\end{array}$ & $\begin{array}{c}\varepsilon f B \\
\%\end{array}$ \\
\hline$\overline{\mathrm{x}}$ & 0,3167 & 3,418 & 10 & 17,22 & - & 225,89 & 1,76 & 224,93 & 1,56 \\
\hline $\mathrm{s}$ & 0,01211 & 0,08159 & 0,000 & 6,94 & - & 41,06 & 0,74 & 44,90 & 0,55 \\
\hline$v$ & 3,82 & 2,39 & 0,00 & 40,28 & - & 18,18 & 41,98 & 19,96 & 35,21
\end{tabular}

